QA: QA

TDR-MGR-GE-000004 REV 00

June 2003

\title{
Data Qualification and Data Summary Report: Intact Rock Properties Data on Poisson's Ratio and Young's Modulus
}

By

E. M. Cikanek

L. E. Safley

T. A. Grant

Prepared for:

U.S. Department of Energy

Office of Civilian Radioactive Waste Management

Office of Repository Development

P.O. Box 364629

North Las Vegas, Nevada 89036-8629

Prepared by:

Bechtel SAIC Company, LLC

1180 Town Center Drive

Las Vegas, Nevada 89144

Under Contract Number

DE-AC28-01RW12101 


\section{DISCLAIMER}

This report was prepared as an account of work sponsored by an agency of the United States Government. Neither the United States Government nor any agency thereof, nor any of their employees, nor any of their contractors, subcontractors or their employees, makes any warranty, express or implied, or assumes any legal liability or responsibility for the accuracy, completeness, or any third party's use or the results of such use of any information, apparatus, product, or process disclosed, or represents that its use would not infringe privately owned rights. Reference herein to any specific commercial product, process, or service by trade name, trademark, manufacturer, or otherwise, does not necessarily constitute or imply its endorsement, recommendation, or favoring by the United States Government or any agency thereof or its contractors or subcontractors. The views and opinions of authors expressed herein do not necessarily state or reflect those of the United States Government or any agency thereof. 
Civilian Radioactive Waste Management Systems

Bechtel SAIC Company, LLC

Data Qualification and Data Summary Report: Intact Rock Properties Data on Poisson's Ratio and Young's Modulus

TDR-MGR-GE-000004 REV 0

Prepared by:

\section{Elumat h. Whane}

E. M. Cikanek

Chairperson

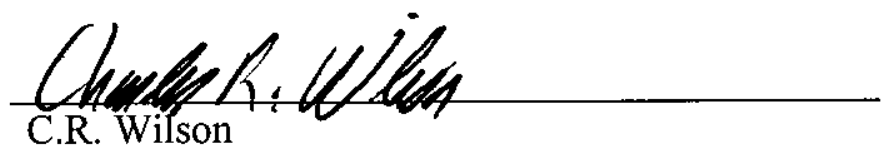

Checker

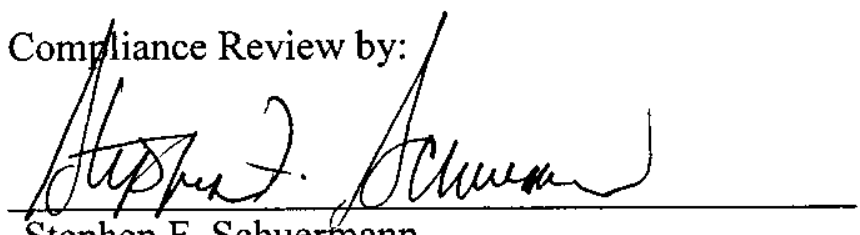

Stephen F. Schuermann

Quality Engineering Representative

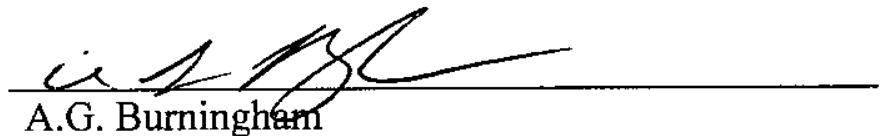

Regulatory and Compliance

Approved by:

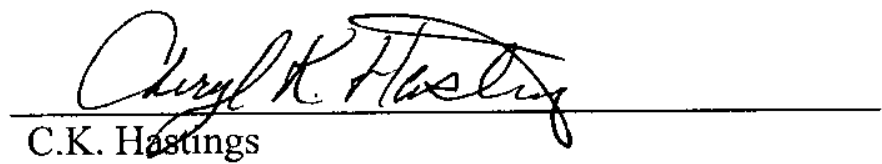

Data Management Manager

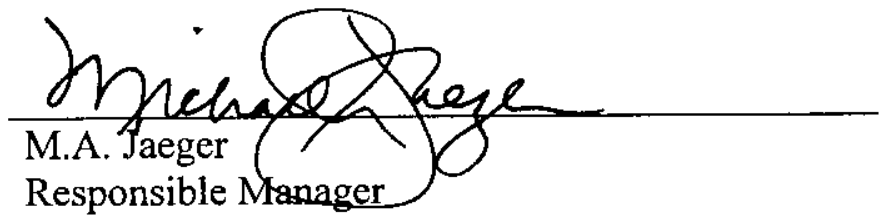

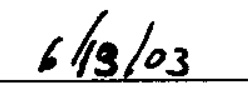

Date
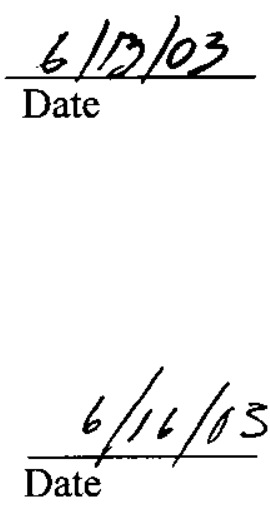

$\frac{6 / 23 / 03}{\text { Date }}$

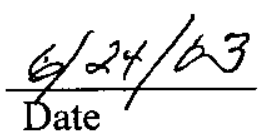

$\frac{6 / 26 / 03}{\text { Date }}$ 


\section{INTENTIONALLY LEFT BLANK}




\section{EXECUTIVE SUMMARY}

This report reviews all potentially available Yucca Mountain Project (YMP) data in the Technical Data Management System and compiles all relevant qualified data, including data qualified by this report, on elastic properties, Poisson's ratio and Young's modulus, into a single summary Data Tracking Number (DTN) MO0304DQRIRPPR.002. Since DTN MO0304DQRIRPPR.002 was compiled from both qualified and unqualified sources, this report qualifies the DTN in accordance with AP-SIII.2Q. This report also summarizes the individual test results in MO0304DQRIRPPR.002 and provides summary values using descriptive statistics for Poisson's ratio and Young's modulus in a Reference Information Base Data Item.

This report found that test conditions such as temperature, saturation, and sample size could influence test results. The largest influence, however, is the lithologic variation within the tuffs themselves. Even though the summary DTN divided the results by lithostratigrahic units within each formation, there was still substantial variation in elastic properties within individual units. This variation was attributed primarily to the presence or absence of lithophysae, fractures, alteration, pumice fragments, and other lithic clasts within the test specimens as well as changes in porosity within the units. As a secondary cause, substantial variations can also be attributed to test conditions such as the type of test (static or dynamic), size of the test specimen, degree of saturation, temperature, and strain rate conditions. This variation is characteristic of the tuffs and the testing methods, and should be considered when using the data summarized in this report. 


\section{INTENTIONALLY LEFT BLANK}




\section{CONTENTS}

Page

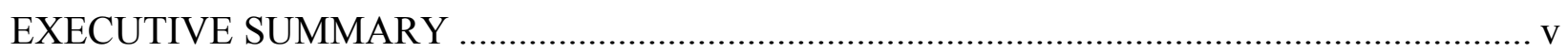

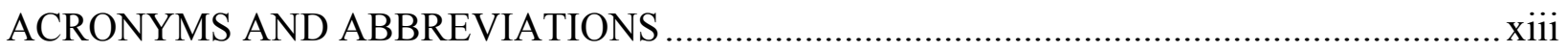

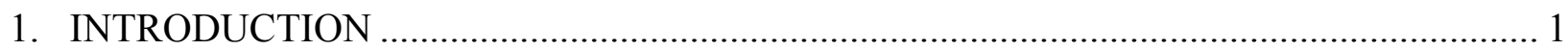

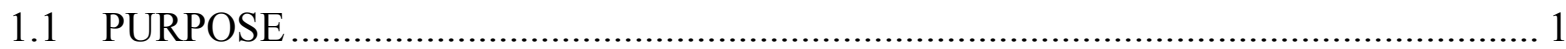

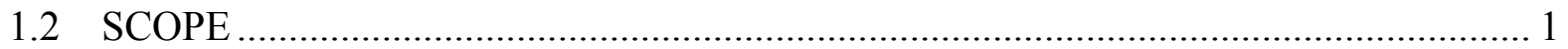

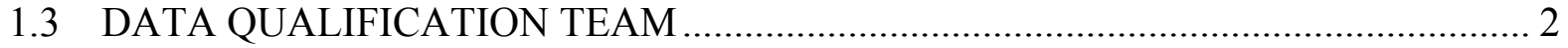

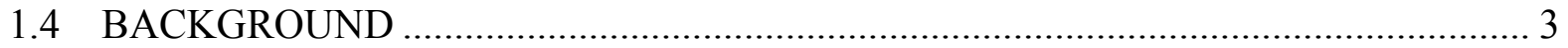

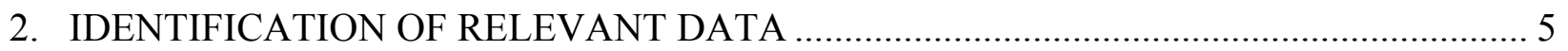

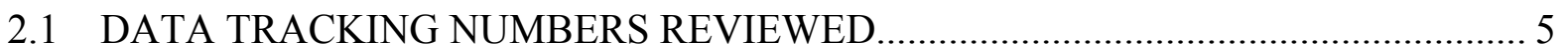

2.2 DATA TRACKING NUMBERS IDENTIFIED AS RELEVANT ................................ 5

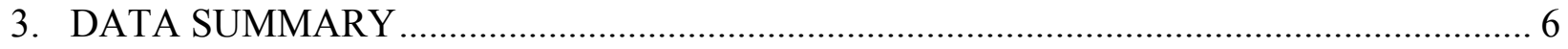

3.1 STATIC POISSON'S RATIO AND YOUNG'S MODULUS....................................... 6

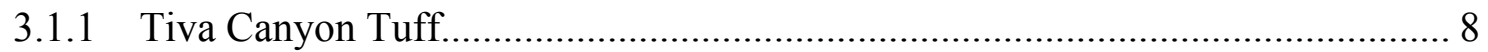

3.1.2 Bedded Tuffs, Yucca Mountain Tuff, and Pah Canyon Tuff ……….................. 8

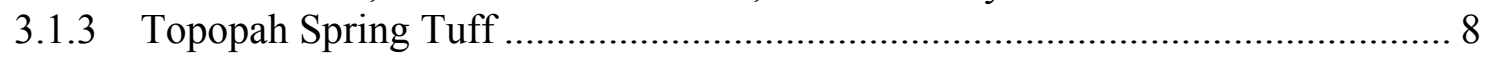

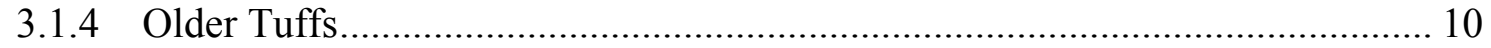

3.1.5 Effect of Temperature, Saturation, and Confining Pressure ............................. 11

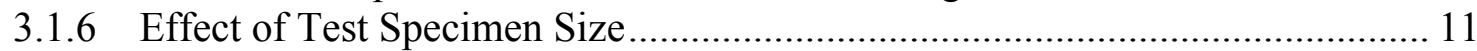

3.1.7 Effect of Test Drainage Conditions ........................................................... 12

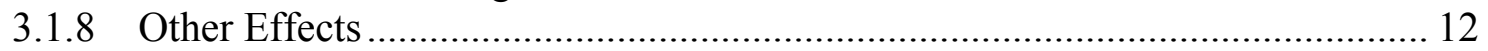

3.2 DYNAMIC POISSON'S RATIO AND YOUNG'S MODULUS................................. 13

3.2.1 Tiva Canyon Tuff..................................................................................... 14

3.2.2 Bedded Tuffs, Yucca Mountain Tuff, and Pah Canyon Tuff ............................. 14

3.2.3 Topopah Spring Tuff .............................................................................. 15

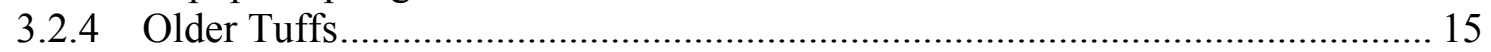

3.2.5 Effect of Confining Pressure .......................................................................... 15

3.2.6 Comparison of Seismic Wave Testing and Uniaxial Compression Tests ......... 16

3.2.7 Downhole Seismic Survey Measurements …………………………………..... 16

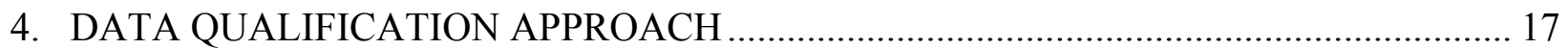

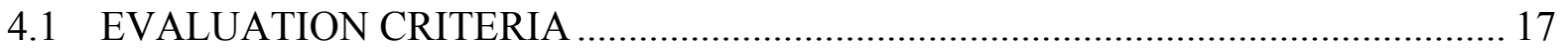

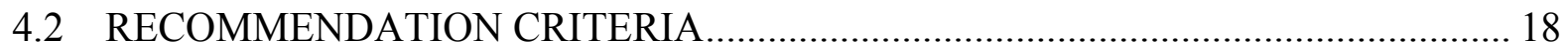

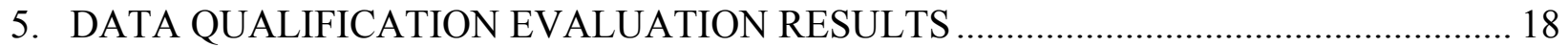

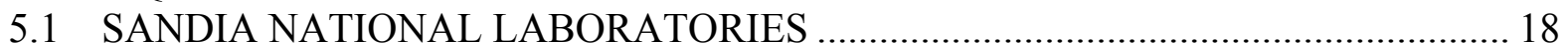

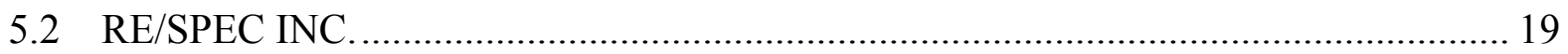

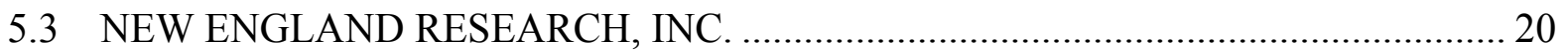

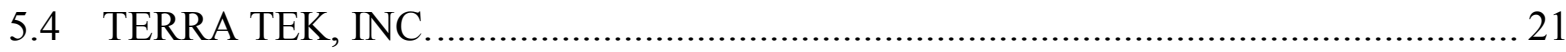

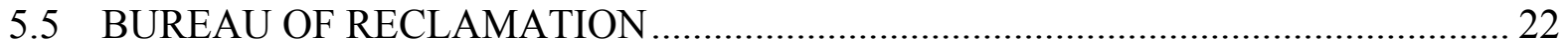




\section{CONTENTS (Continued)}

Page

5.6 COMPARISON OF DATA SETS ................................................................... 22

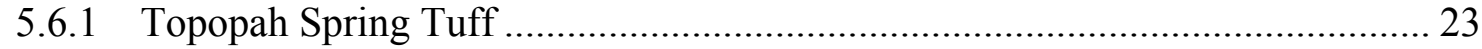

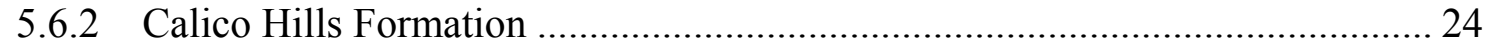

5.6.3 Prow Pass and Bullfrog Tuffs ...................................................................... 24

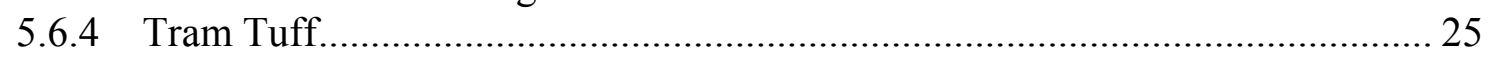

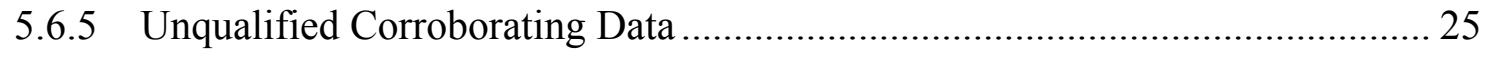

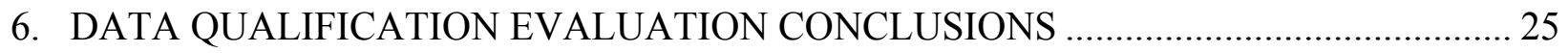

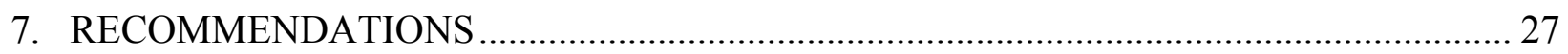

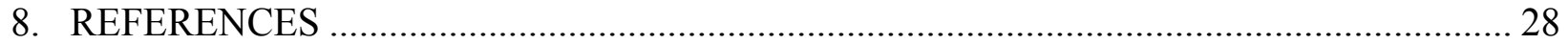

8.1 DOCUMENTS CITED ........................................................................................ 28

8.2 CODES, STANDARDS, REGULATIONS, AND PROCEDURES ........................... 30

8.3 SOURCE DATA, LISTED BY DATA TRACKING NUMBER ........................... 31

ATTACHMENT A - STRATIGRAPHIC COLUMN OF THE YUCCA MOUNTAIN

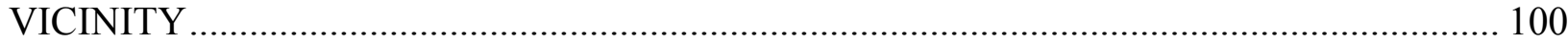




\section{FIGURES}

Page

1. Static Young's Modulus (GPa) and Poisson's Ratio Frequency Distribution for Tpcrn

2. Static Young's Modulus (GPa) and Poisson's Ratio Frequency Distribution for

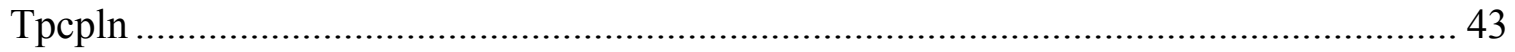

3. Static Young's Modulus (GPa) and Poisson's Ratio Frequency Distribution for

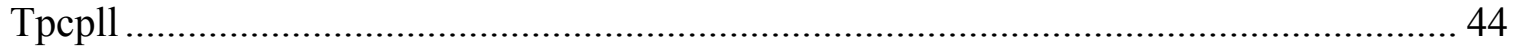

4. Static Young's Modulus (GPa) and Poisson's Ratio Frequency Distribution for Tpcpmn .................................................................................................... 45

5. Static Young's Modulus (GPa) and Poisson's Ratio Frequency Distribution for

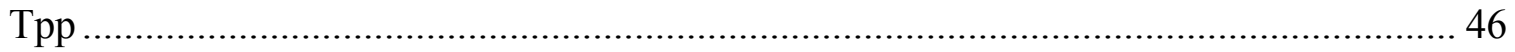

6. Static Young's Modulus (GPa) and Poisson's Ratio Frequency Distribution for

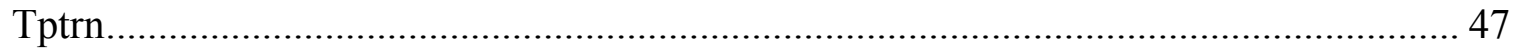

7. Static Young's Modulus (GPa) and Poisson's Ratio Frequency Distribution for Tptpul ............................................................................................................... 48

8. Static Young's Modulus (GPa) and Poisson's Ratio Frequency Distribution for

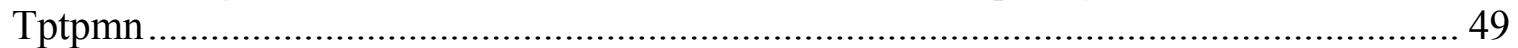

9. Static Young's Modulus (GPa) and Poisson's Ratio Frequency Distribution for

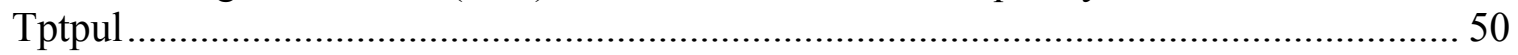

10. Static Young's Modulus (GPa) and Poisson's Ratio Frequency Distribution for

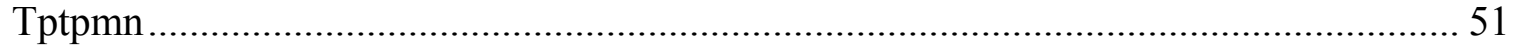

11. Static Young's Modulus (GPa) and Poisson's Ratio Frequency Distribution for Tptpll................................................................................................................... 52

12. Static Young's Modulus (GPa) and Poisson's Ratio Frequency Distribution for

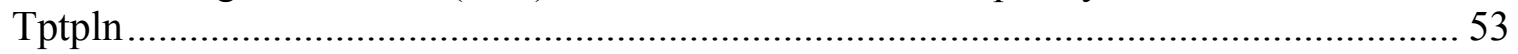

13. Static Young's Modulus (GPa) and Poisson's Ratio Frequency Distribution for

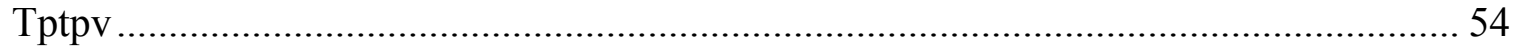

14. Static Young's Modulus (GPa) and Poisson's Ratio Frequency Distribution for Tac. 


\section{INTENTIONALLY LEFT BLANK}




\section{TABLES}

Page

1. DTNs Containing Potentially Relevant Data for Poisson's Ratio and Young's

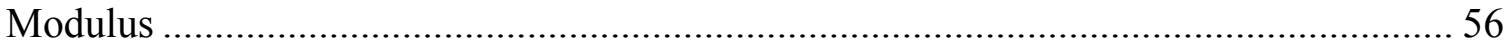

2. DTNs That Were Qualified and Verified at the Start of the Review ............................... 82

3. Qualified DTNs That Required Verification at the Start of the Review........................... 84

4. DTNs that Required Qualification at the Start of the Review ......................................... 85

5. Summary of Static Test Results for Poisson's Ratio under Saturated and Ambient

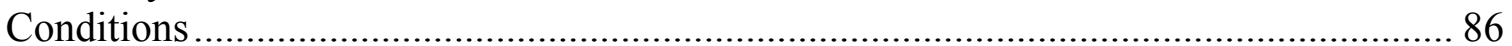

6. Summary of Static Test Results for Young's Modulus under Saturated and Ambient Conditions .................................................................................................. 88

7. Summary of Static Young's Modulus Results (GPa) from Saturated Tptpul

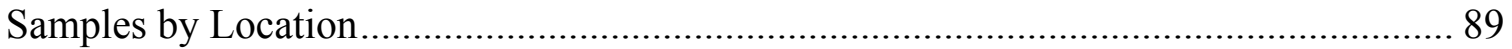

8. Summary of Static Young's Modulus Results (GPa) from Saturated Tptpmn Samples by Location.............................................................................................. 90

9. Summary of Static Test Results for Young's Modulus (GPa) under Room Temperature and Increasing Confining Pressure Conditions ........................................... 90

10. Summary of Static Test Results for Young's Modulus under High Temperature (T150) and Increasing Confining Pressure Conditions..................................................... 90

11. Summary of Static Test Results from Variation in Sample Size on Intact Cylindrical Samples of the Topopah Spring Member From Busted Butte....................... 91

12. Summary of Dynamic Test Results for Poisson's Ratio from Shear Wave Measurements under Dry and Wet Conditions ................................................................ 91

13. Summary of Dynamic Test Results for Young's Modulus from Shear Wave Measurements under Dry and Wet Conditions ................................................................. 92

14. Summary of Dynamic Test Results on Poisson's Ratio Obtained from Downhole Seismic Surveys in the Vicinity of Yucca Mountain....................................................... 93

15. Available Documentation for Unqualified Sources ......................................................... 94

16. Summary of Static Poisson's Ratio Results from Saturated Tptpmn Samples by

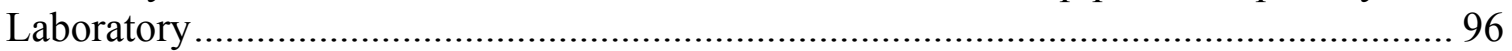

17. Summary of Static Poisson's Ratio Results from Unsaturated Tptpmn Samples by

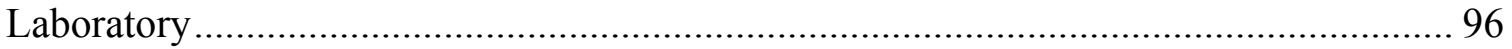

18. Summary of Static Young's Modulus Results (GPa) for Saturated Tptpmn Samples by Laboratory ................................................................................................ 96

19. Summary of Static Young's Modulus Results (GPa) for Unsaturated Tptpmn Samples by Laboratory .......................................................................................... 97

20. Summary of Static Poisson's Ratio Results for Saturated Tptpmn Samples by Location

21. Summary of Static Poisson's Ratio Results for Unsaturated Tptpmn Samples by Location

22. Summary of Static Young's Modulus Values (GPa) from Saturated Tptpmn Samples by Location.....

23. Summary of Static Young's Modulus Values (GPa) from Unsaturated Tptpmn Samples by Location. 
24. Summary of Static Young's Modulus Values (GPa) for Saturated Tptpll Samples

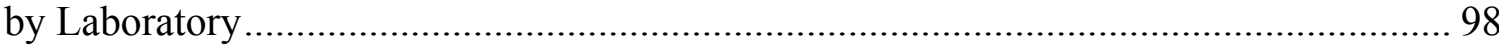

25. Summary of Dynamic Poisson's Ratio Results for Tptpmn Samples by Saturation and Location

26. Summary of Dynamic Young's Modulus Results (GPa) for Tptpmn Samples by Saturation and Location

A-1. Stratigraphic Column of the Yucca Mountain Vicinity 


\section{ACRONYMS AND ABBREVIATIONS}

DOE U.S. Department of Energy

DTN data tracking number

ESF Exploratory Studies Facility

$\mathrm{GPa} \quad$ gigapascals

LLNL Lawrence Livermore National Laboratory

LVDT linear variable displacement transformer

$\mathrm{MPa} \quad$ megapascals

NER New England Research, Inc.

OCRWM Office of Civilian Radioactive Waste Management

psig pounds per square inch gauge

QA Quality Assurance

QARD Quality Assurance Requirements and Description

RIB Reference Information Base

RIS Record Information System

SNL Sandia National Laboratories

TDMS Technical Data Management System

T22 samples tested at room temperature (nominal $22^{\circ} \mathrm{C}$ )

T150 samples tested at $150^{\circ} \mathrm{C}$

T200 samples tested at $200^{\circ} \mathrm{C}$

TBV to be verified

TDMS Technical Data Management System

USBR U.S. Bureau of Reclamation

USGS U.S. Geological Survey

YMP Yucca Mountain Project 


\section{INTENTIONALLY LEFT BLANK}




\section{INTRODUCTION}

\subsection{PURPOSE}

This report presents a systematic review of the available data in the Technical Data Management System (TDMS) that are relevant to the following intact rock properties: Poisson's ratio and Young's modulus. Relevant data were evaluated, and both qualified data and unqualified data that were qualified by this report were compiled into the unqualified summary DTN MO0304DQRIRPPR.002. This report evaluates the data in the summary DTN for qualification using the method of corroborating data as defined in Attachment 2 to AP-SIII.2Q. This report also presents a summary of the compiled information in the form of descriptive statistics and recommended values that are contained in a Reference Information Base (RIB) Data Item prepared in accordance with AP-SIII.4Q.

The primary purpose of this report is to produce a qualified set of data from intact rock Poisson's ratio and Young's modulus testing done over the course of the Yucca Mountain Project (YMP). A second purpose is to provide a qualified summary (i.e., a RIB Data Item) of the test results based on DTN MO0304DQRIRPPR.002 using descriptive statistics and graphical presentations. Both of these products are intended for use in the License Application design and safety analysis. The immediate purpose of this report is to support the data needs of repository design; however, the products are also intended to be appropriate for general use by the YMP. The appropriateness and limitations, if any, of the data, with respect to the intended use, are addressed in this report.

\subsection{SCOPE}

The scope of this report is described in Technical Work Plan For: Qualification of Intact Rock Properties Data on Poisson's Ratio and Young's Modulus (BSC 2002), and updated in 2003 (BSC 2003). The Technical Work Plan identifies 142 DTNs containing Intact Rock Properties data on Poisson's ratio and Young's modulus. The modulus of deformation was included in the technical work plan for this report; however, the data for this parameter were outside the scope of this report and were not carried forward in the evaluation. The data were collected by the U.S. Geological Survey (USGS), Sandia National Laboratories, Lawrence Livermore National Laboratory, and the Yucca Mountain Project (YMP). The data in a significant number of these DTNs are categorized as unqualified. These data are generally unqualified because the data, or some of the source data presented in source DTNs, were acquired in the 1980 to 1987 time frame, prior to the existence of the Office of Civilian Radioactive Waste Management (OCRWM) Quality Assurance Requirements and Description (QARD), DOE/RW-0333P, and under procedures that had not, at that time, been approved for YMP work. YMP procedures require that these data be qualified prior to direct use in analyses, calculations, or design. The plan includes the following major activities and products that are documented in this report.

- An identification, review, and disposition of all potentially relevant DTNs that might contain data related to properties under consideration. This review began on July 1, 2002 and was completed on September 30,2002. Some data submittals or other changes to the 
Automated Technical Data Tracking System may have occurred since the review as part of ongoing efforts and are not reflected in this report.

- Data from DTNs identified as containing relevant information were further evaluated. Relevant qualified data, and data qualified by this report have been compiled into a single data set, and a new DTN (MO0304DQRIRPPR.002) was created for the summary data set contained in this report.

- Those DTNs that were identified as relevant in the first activity and that require verification have been reviewed using the Data Confirmation Checklist in AP-3.15Q. If adequate documentation could not be found to complete the verification process for a particular DTN, the relevant data from that DTN were evaluated as part of the qualification process in the next activity.

- Data in the summary DTN that were identified as relevant in the first activity and that are unqualified have been included in the data to be qualified in accordance with AP-SIII.2Q.

- The final activity will be the preparation of a Reference Information Base (RIB) Data Item that summarizes the data in the data summary DTN. The RIB item will be prepared and submitted in accordance with AP-SIII.4Q.

This report summarizes available data and is therefore prepared under the requirements of AP-3.11Q, while it also responds to the reporting requirements contained in AP-SIII.2Q. No assumptions were made prior to the data identification or during the data disposition, evaluation, and qualification. Only YMP standard software (WORD and EXCEL) were used to generate the information and provide statistical summaries of the data contained in this technical report.

\subsection{DATA QUALIFICATION TEAM}

The Data Qualification Team consisted of the following members:

The Responsible Manager for the data qualification task is Michael A. Jaeger.

Chairperson

Mr. Edward M. Cikanek is designated the Chairperson for this Data Qualification Team. Mr. Cikanek is a subject matter expert in the field of geotechnical engineering and the design of underground structures. He has an M.S. degree in civil engineering from the University of Notre Dame (1966) and a B.S. degree in civil engineering from Northwestern University (1964). He has over 35 years of experience in performing design and engineering services for the construction of foundations, embankments, and underground structures. As the lead engineer and group leader for geotechnical departments involved in tunneling projects, he has an extensive background in the collection and use of geotechnical data for tunneling projects. Mr. Cikanek has had no involvement with the collection or processing of the YMP data being qualified. 
Technical Representatives:

Mr. Leslie Eugene Safley is a Data Qualification Team member. He has an M.S. degree (1989) in Geology and a B.S. degree (1981) in Geology from Oregon State University and an MBA degree (1998) from Oklahoma State University. He has a broad background in stratigraphy, hydrogeology, and geophysical data collection and analysis. He has worked on the YMP for four years as a technical report writer and a database administrator of geological and engineering data. Previously, he worked as a project geologist responsible for developing reservoir management plans at the DOE's National Institute of Petroleum and Energy Research. Mr. Safley has had no involvement with the collection or processing of the YMP data being qualified.

Mr. Terry Grant is a Data Qualification Team member. He has an M.S. degree (1974) in geology from the University of Nevada, Reno and a B.S. degree (1968) from UCLA. Mr. Grant is an engineering geologist with experience in site studies and the management of large multidisciplinary projects. He has been responsible for conceiving site selection methodologies and for implementing data gathering studies for high-level nuclear waste repositories and nuclear power plants requiring quality assurance programs. He has worked as a team member on previous data qualification activities and has a broad background in data gathering activities. Mr. Grant has had no involvement with the collection or processing of the YMP data being qualified.

\subsection{BACKGROUND}

This report considers testing that is related to the excavation of rock by drilling and coring to determine intact rock strength. For the purposes of this report, rock strength (or peak strength) is defined as the maximum stress that the rock specimen can sustain under a given set of environmental conditions (e.g., temperature, saturation, and confining pressure). Specimen failure by fracturing and loss of cohesion occurs during the test at the peak strength.

Uniaxial and triaxial compression testing are frequently used strength tests for rocks. These are called "static" tests. These tests are used to determine static compressive strength and the elastic constants, Young's modulus and Poisson's ratio. The preparation of rock core specimens was conducted in accordance with ASTM procedure D-4543-85. The uniaxial compressive testing was conducted in accordance with the applicable portions of ASTM procedures D-2938-79, D2938-86, and D-3148-86. The triaxial compressive testing was conducted in accordance with the applicable portions of ASTM procedures D-2664-80 and D-2664-86. The tests are performed on machined cylinders of rock taken from cores. The tests basically consist of compressing the ends of a rock cylinder between platens at a constant stress rate through the point of failure. The axial load and deformation (strain) are recorded throughout the tests (Brady and Brown 1993, p. 90).

Triaxial compression testing is similar to uniaxial compression testing except that an axi-symmetric confining pressure is applied to the walls of the rock cylinder during the test. The test cylinder is placed in an impervious jacket of copper foil, rubber, or plastic and the confining pressure is applied using a fluid (e.g., hydraulic oil, argon) contained in a test cell surrounding the specimen. Triaxial compression testing is also considered a routine rock strength test. 
Differential stress is calculated by dividing the post-hydrostatic vertical loading force (force greater than that resulting from confining pressure) by the original cross-sectional area of the sample. Axial strain is measured by dividing measured axial displacements by the original sample length. Lateral strain is measured by dividing the lateral displacement across one sample diameter by the original diameter of the test specimen. Young's modulus and Poisson's ratio are determined from the slopes of the linear regression fits to the differential stress-axial strain and lateral strain-axial strain data, respectively. The fits are obtained using only those data corresponding to the stress states from 10 to 50 percent of the ultimate strength of the particular test sample.

The dynamic intact rock properties data addressed in this report were computed from the measured shear and compressional wave velocities and estimated bulk densities, with the assumption that the media are isotropic. The dynamic testing was conducted in accordance with the applicable portions of ASTM procedure D2845-83. The compressional and shear wave velocities were measured in a benchtop apparatus that applied an axial stress of approximately $0.4 \mathrm{MPa}$ to the specimen. The wave velocities of the samples were obtained by measuring oneway travel time along the rock core axis and then dividing by the sample length. The source transducers are in a piston used to load the sample and the receiver transducers are located in the base of the apparatus.

The source crystal is excited by a fast rise time electrical pulse generated with a pulsar/receiver. The crystal produces a broadband ( 300 to $800 \mathrm{kHz}$ ) ultrasonic pulse that propagates through the adjacent titanium end piece, through the rock sample along the core axis, through the titanium end piece at the opposite end of the core, and into the crystal receiver. The electrical signal produced by the receiver crystal is amplified and filtered by the receiving section of the pulsar/receiver, then fed into a digital oscilloscope. The oscilloscope digitizes the ultrasonic waveform and displays the digitized signal. The travel times are determined by picking the point at which the threshold voltage is exceeded relative to the baseline voltage. The resolution of the pick is +/- 0.01 millisecond. The dynamic Young's modulus and Poisson's ratio were computed from the travel time data.

The static intact rock properties data addressed in this report were measured on core samples from boreholes in the vicinity of Yucca Mountain, from subsurface sample locations in the Exploratory Studies Facility (ESF), and on samples taken from surface outcrop locations at Busted Butte. The dynamic intact rock properties data addressed in this report were computed from boreholes in the vicinity of Yucca Mountain and on samples taken from surface outcrop locations at Busted Butte. The data resulting from these tests are contained in a large number of individual DTNs that are linked to several different parameter names in the TDMS. Over the course of the YMP, several contract laboratories and national laboratories have been involved in performing the actual tests. In many cases, the DTNs report the test results for a variety of rock properties for the borehole interval or location in question. This report only considers the Poisson's ratio and Young's modulus measurement results from those DTNs. Other reports will consider the remaining test results. 


\section{IDENTIFICATION OF RELEVANT DATA}

\subsection{DATA TRACKING NUMBERS REVIEWED}

A systematic review of the contents of the TDMS was conducted to identify all DTNs that might contain data relevant to the properties of Poisson's ratio and Young's modulus. Every DTN in the TDMS is categorized as relevant to one or more TDMS Parameters. DTNs linked to the following TDMS Parameters were reviewed for relevant data:

- Poisson's ratio

- Intact Rock Poisson's ratio

- Young's modulus

- Intact Rock Young's modulus.

The Technical Data Parameter Dictionary element of the TDMS provides definitions for the above parameters. The search identified 142 unique DTNs related to one or more of the above parameters. Each of these DTNs was reviewed to determine if the DTN contained data relevant to the intact rock properties considered by this report. If a DTN listed source DTNs, those source DTNs were also checked. The DTNs reviewed and the resulting dispositions for the DTNs are listed in Table 1. The status, comments, and disposition represent information available as of July 1, 2002, and may not represent the current status.

\subsection{DATA TRACKING NUMBERS IDENTIFIED AS RELEVANT}

Table 1 identifies 50 DTNs containing potentially relevant data for this report as Directly Used or Corroborating. The DTNs that were dispositioned as Directly Used are qualified data sets (either verified or unverified) that were carried forward for evaluation. Those DTNs that were dispositioned as Corroborating are unqualified data sets that were carried forward for evaluation and, if required, qualification. All other DTNs were not carried forward and no further evaluation was performed. Of the 50 DTNs carried forward for evaluation, 20 were identified as Qualified and Verified (Table 2), 13 were identified as Qualified but not Verified (Table 3), and 17 were identified as Unqualified (Table 4) at the start of the review. The DTNs listed on Table 3 underwent verification in accordance with AP-3.15Q, as part of the process for completing this report. As a result of the verification process, all but three of the 13 DTNs are now identified as qualified and verified in TDMS. The documentation for this part of the process has been submitted to the RIS and is linked to the DTNs in TDMS. As a result of the verification review, three DTNs on Table 3 (GS921283114220.009, LL990205304243.032, and SNSAND91089400.000) had their status changed from qualified to unqualified. The data from these three DTNs are considered in Sections 5 and 6 with the unqualified data from the DTNs listed in Table 4.

All qualified data and data qualified by this report relevant to Poisson's ratio and Young's modulus test results were compiled from the 50 sources and a new DTN (MO0304DQRIRPPR.002) was generated for the consolidated data set. The consolidated data set includes information on the results of testing and supporting information on the sample location, lithostratigraphic interval, sample size, test environmental conditions, and references to associated reports and records. Not all of this information was available from the source DTNs. 
Many of the source DTNs used to compile DTN MO0304DQRIRPPR.002 only locate the sample by borehole depth and do not give a stratigraphic location or use different stratigraphic systems. Lithostratigraphic assignments were made using the contacts identified in DTN MO0004QGFMPICK.000. Supplemental information on contacts in the upper part of the Tiva Canyon Formation was derived from DTNs GS931108314211.041, GS931008314211.037, GS931008314211.038, GS931008314211.039, GS931208314211.046, GS931008314211.045, GS940908314211.045, and GS940408314211.020. Information on the stratigraphic location of outcrop samples taken from Busted Butte was determined through a review of the stratigraphic columns in Price (1986, Figure 2 and 3) and Price et al. (1985, Figure 2). The lithostratigraphic system used in this report follows the stratigraphic subdivision documented in MO0004QGFMPICK.000 and GS931208314211.049 and is presented in Appendix A. Other supplemental information was taken from supporting records in the RIS (e.g., reports, data sheets, maps, etc.).

The original DTNs generally contain data for other properties that are not the focus of this report and those data were not carried forward. DTN MO0304DQRIRPPR.002 serves as the source for the discussion of the consolidated testing data in Section 3. Since DTN MO0304DQRIRPPR.002 contains information derived from both qualified and unqualified sources, the DTN must be qualified prior to use. Sections 4, 5, and 6 document the qualification of DTN MO0304DQRIRPPR.002. The source DTNs listed in Table 4 are not qualified by this report and will remain unqualified.

\section{DATA SUMMARY}

\subsection{STATIC POISSON'S RATIO AND YOUNG'S MODULUS}

This section summarizes the qualified and unqualified static Poisson's ratio and Young's modulus data contained in DTN MO0304DQRIRPPR.002 by lithostratigraphic unit using standard measures from descriptive statistics. The data are reviewed to evaluate trends and distributions, to identify anomalies that require explanation, and to review the effects of different test environments on elastic behavior. The discussion concentrates on those units for which a sufficient number of tests were run to allow this type of review.

Tests were run under a variety of saturation states, temperatures, and other conditions that can impact test results. For the purposes of summarizing the data, tests conducted under similar conditions were grouped into categories. All tests that were categorized in the source documents as being run under ambient temperature, room temperature, or $22^{\circ} \mathrm{C}$ temperature, are considered to be in a single room-temperature category (T22). Similarly, all tests that were categorized in the source documents as wet or saturated are considered to be in a single saturated category (Sat). Although samples are categorized as saturated, 100 percent saturation was not always achieved. Most of the tests were run with fully saturated samples (S100) at room temperature (T22). A summary of the results from this testing is given in Tables 5 and 6.

The second largest set of tests was run with samples at ambient saturation at room temperature (T22). A summary of the results by lithostratigraphic unit from this testing is also given in Tables 5 and 6 . The ambient saturation category generally indicates that the samples were tested 
in an "as-received" condition (e.g., not saturated for testing). However, these samples may not represent in situ conditions since some drying probably occurred in storage at the Sample Management Facility (SNL 1997, p. 3). Saturation at testing is not always recorded for these samples, but SNL (1997, Table 3) indicates that saturation ranged from 30 to 80 percent with most samples in the 40 to 60 percent range for the samples covered by that report. All tests that were categorized in the source documents as ambient, as-received, or unsaturated, are considered in a single Ambient category. Prior to dynamic testing, some samples were also air dried after machining to remove water used as a coolant. These samples are considered as Dry in Tables 12 and 13 .

A smaller number of tests were run under other environmental conditions. These included tests run at temperatures of 150 and $200^{\circ} \mathrm{C}$ (T150, T200). Other test conditions that were varied between groups of tests include sample size (diameter and length of the test cylinder) and variation in confining pressures. For confined triaxial tests, principal variables are confining pressure and whether the specimen was allowed to drain pore fluid during the test. Some of the data evaluated reported whether the test was performed drained or undrained. Sample sizes and confining pressures are indicated for each test in DTN MO0304DQRIRPPR.002. Summaries of tests run at various temperatures and confining pressures are given in Tables 8 and 9. Effects on Young's modulus of varying sample sizes are shown in Table 11.

There is a rather wide variability in the Poisson's ratio and Young's modulus test results for each of the lithostratigraphic units included in DTN MO0304DQRIRPPR.002, even when other environmental conditions that can affect results are accounted for. This is not the result of accuracy limitations in the testing equipment or procedures, but reflects the variation in characteristics of the tuff samples. These ash-flow and bedded tuff units are heterogeneous by nature, particularly at the scale of most of the rock cylinders that were tested $(25.4$ and $50.8 \mathrm{~mm}$ diameter). Undetected features that could affect sample behavior include lithophysae, pumice clasts, lithic fragments, minor fractures (mineralized or open), and alteration zones. Lithophysae are characteristic of some cooling zones in the ash flows and consist of hollow, bubble-like structures composed of concentric shells of finely crystalline minerals within the rock matrix. These voids formed from air or gas trapped in the flow during deposition or exsolved from the rock during cooling. Depending on the abundance of these features, Poisson's ratio and Young's modulus can be significantly reduced.

Computerized tomographic X-ray images were made of some test samples (e.g., Boyd et al. 1996, p. 37). The X-ray imaging showed that some samples had large lithophysal cavities within the test specimen that may have resulted in lower strength for these samples. Nimick et al. (1987, pp. 14 to 15,18 to 19) report an example of lithologic variability where some samples from the USW G-2 borehole were found to have very different mineralogical and physical characteristics from other samples tested. The samples had higher porosity and lower bulk density than other samples in the unit. This also resulted in lower compressive strengths. Nimick et al. (1987, p. 19) also note that minor fracturing also affected results for some samples. No attempt was made to cull or delete such test results from the listing in DTN MO0304DQRIRPPR.002 or from the summaries presented in this report, since these samples are representative of the natural variability that can occur within these ash-flow units. However, this variability can be significant in interpreting test results from lithostratigraphic units where a small number of tests were run. 


\subsubsection{Tiva Canyon Tuff}

Static Poisson's ratio and Young's modulus measurement results for the Tiva Canyon Tuff (Tpc) at full saturation (S100) and room temperature (T22) are summarized in Tables 5 and 6 . These tables and Figures 1 through 4 show that there is significant variation between the lithostratigraphic units within the formation. The crystal-rich nonlithophysal zone (Tpcrn, Figure 1) has markedly low Young's modulus and Poisson's ratio (means of $15.1 \mathrm{GPa}$ and 0.204, respectively). In contrast, the crystal-poor nonlithophysal and lithophysal zones, as illustrated by the lower nonlithophysal zone (Tpcpln, Figure 2) and lower lithophysal (Tpcpll, Figure 3), have significantly higher strength with Young's modulus generally over $30 \mathrm{GPa}$. In addition, the crystal-poor lithophysal zones (Tpcpul and Tpcpll) have lower Young's modulus values than the crystal-poor nonlithophysal zones (Tpcpmn (Figure 4) and Tpcpln) (means of 23.7 and $30.9 \mathrm{GPa}$ versus means of 35.5 and $34.2 \mathrm{GPa}$, respectively). Poisson's ratio values do not show a strong variation between nonlithophysal and lithophysal zones.

Because the lithostratigraphic units have basically the same chemical composition, the foregoing differences can be attributed to variation in the degree of crystallization, fracturing, porosity, and lithophysal development. Representative examples of unconfined and confined compression tests show the effects of degree of welding. Higher degrees of welding in the crystal poor nonlithophysal zones cause higher strengths, higher Young's modulus, and smaller strains to failure than the nonwelded lithophysal tuff. Young's modulus is also found to be inversely dependent on porosity for confining pressures of 0 and $20 \mathrm{MPa}$. Porosity differences may be a primary factor in these Young's modulus differences. The Tpcrn and Tpcpv zones are relatively porous (mean total porosities of approximately 23 and 34 percent, respectively) when compared to the Tpcpln zone (mean total porosity of approximately 12 percent). Porosity, like lithophysae, can reduce Young's modulus by reducing the elasticity of the rock matrix. The scatter of the data can be thus attributed to variations in mineralogy associated with degree of welding and porosity.

\subsubsection{Bedded Tuffs, Yucca Mountain Tuff, and Pah Canyon Tuff}

Static Young's modulus and Poisson's ratio measurement results for the units below the Tiva Canyon Tuff (Tpc) and above the Topopah Spring Tuff (Tpt) are presented in Tables 5 and 6. These units consist of a series of bedded air-fall tuffs (Tpbt4, Tpbt3, and Tpbt2) and two thin ash-flow (ignimbrite) units, the Yucca Mountain Tuff (Tpy) and the Pah Canyon Tuff (Tpp). Several tests were run at ambient conditions and full saturation, and room temperature. Each of these units exhibits very low Young's modulus, generally less than 5 GPa (e.g., Tpp, Figure 5). Poisson's ratio for bedded air-fall tuffs is generally less than 0.24 , and ranges from 0.13 to 0.40 . Poisson's ratio for the Pah Canyon Tuff has a wide distribution (0.09 to 0.53) with a mean of 0.28 (Figure 5). The low Young's modulus and the range of variation in Poisson's ratio can be attributed to the high porosity (generally 30 to 50 percent) and variable lithology of these units.

\subsubsection{Topopah Spring Tuff}

Static Young's modulus and Poisson's ratio test results for the Topopah Spring Tuff are summarized in Tables 5 and 6 . The distribution of test results for lithostratigraphic units with a significant number of tests is illustrated in Figures 6 through 13. The Topopah Spring Tuff is zoned in a fashion similar to the Tiva Canyon Tuff. The elastic properties of these zones are also 
similar to those found in the Tiva Canyon Tuff. The upper three zones, the crystal-rich vitric zone (Tptrv3), the crystal-rich nonlithophysal zone (Tptrn), and the crystal-rich lithophysal zone (Tptrl), have relatively low Young's modulus (means generally between 10 and $20 \mathrm{GPa}$ ). The test results at full saturation and room temperature of core specimens from boreholes for the Tptrn zone are illustrated in Figure 6. As with the Tiva Canyon Tuff, the lower Young's modulus is probably the result of variations in the degree of crystallization, fracturing, porosity, and lithophysal development.

Testing in the next lower zones, the crystal-poor upper lithophysal zone (Tptpul) and the crystalpoor middle nonlithophysal zone (Tptpmn), is complicated by the testing strategy that evolved over the course of site characterization. Test samples were divided between two major sources. The first source was core from various boreholes and surface samples that came from locations scattered across the potential repository site area. The second source was a single outcrop on Busted Butte, which yielded a large number of samples. The Busted Butte samples consisted of large (up to 3 cubic-meters), irregular blocks that were collected from the southeastern flank of the butte (Price 1986, p. 4). Each block was numbered (e.g., Block 10) and the sample numbers were usually based on the block number (e.g., 10AE24Y or BB-10-AE-32Y).

Most blocks were from the Tptpmn zone but some blocks came from the overlying Tptpul zone (Price 1986, Figures 2 and 3, and Price et al. 1985, Figure 2). A very large number of cores was cut and tested from these blocks. The mean for Young's modulus from borehole samples for Tptpul is $21.16 \mathrm{GPa}$ with a standard deviation of $7.84 \mathrm{GPa}$ (Table 7). For Busted Butte samples, the mean is $15.47 \mathrm{GPa}$ with a standard deviation of $3.15 \mathrm{GPa}$. The mean Poisson's ratio for Tptpul from saturated borehole samples is 0.25 with a standard deviation of 0.130 , compared with a mean of 0.158 and standard deviation of 0.031 from Busted Butte samples.

While the difference between Young's modulus values from borehole and Busted Butte samples for Tptpmn is not as pronounced as for Tptpul, some variation between borehole and Busted Butte samples does exist (Table 7). The large number of samples from the single outcrop at Busted Butte and the variation in values compared with samples from other locations can strongly bias or skew the overall results for these zones. Considering all sample measurements individually, Poisson's ratio (Figure 7) and Young's modulus (Figure 8) values both have a wide distribution, sometimes with several minor peaks. The Busted Butte samples account for many of the higher elastic property values, and some of the lower values measured. To account for this bias from a single location, Tables 5 and 6, and Figures 9 and 10 use a mean value for the Busted Butte tests as a single "measurement" rather than including the results for each Busted Butte sample analysis. The set of individual Busted Butte results is used as a separate population to assess the impact variations in specimen saturation, temperature, sample size, and differences between individual laboratory measurements.

In several other cases, three or four tests were run on specimens from the same depth in a borehole. These tests were treated as individual tests and were not grouped or averaged. This was done because the number of closely spaced specimens was generally small enough that the overall mean would not be affected and because the variability between these specimens was usually as high as that exhibited for the entire sample population. The closely spaced specimens were, therefore, included as individual tests to better illustrate the range of variation that can be expected from testing within these cooling zones. 
The distributions illustrated in Figure 9 for the lithophysal Tptpul zone show a very broad range of values. The most likely explanation for this distribution is that it is the result of test specimens either containing internal lithophysae or not. The distribution is probably further broadened by the size and number of lithophysae included in the lithophysal specimens. Another possible explanation is variation in test specimen preparation and environmental testing conditions. In contrast, the distribution for the nonlithophysal Tptpmn zone (Figure 10) shows a more concentrated distribution about a mean Young's modulus (approximately $33.31 \mathrm{GPa}$ ) that is considerably higher than the overlying zones.

The distribution of test results from the crystal-poor lower lithophysal zone (Tptpll) is illustrated in Figure 11. Like the Tptpul, this lithophysal unit also displays a very broad distribution except that there is a larger data set for this zone. Again, the broad range probably results from lithophysae occurring in varying proportions within the test specimens. The higher the abundance of lithophysae, the lower the strength (and the Young's modulus) of the sample. The higher end of the Young's modulus distribution is therefore probably more representative of the intact matrix (i.e., without lithophysae) strength of this zone.

The results for the crystal-poor lower nonlithophysal zone (Tptpln) are illustrated on Figure 12. These results are similar to the nonlithophysal Tptpmn with a general normal distribution about a pronounced mean and median value of $33.88 \mathrm{GPa}$. The distribution shows a pronounced tail at the lower strengths that most likely represents samples with lithophysae, fractures, or other material properties that reduce specimen strength.

The distribution of test results for the upper-most interval of the lower-most zone of the Topopah Spring Tuff, the crystal-poor vitric zone (Tptpv3), is illustrated in Figure 13. The uppermost interval (Tptpv3) has a mean Young's modulus of $36.1 \mathrm{GPa}$, similar to that of the overlying crystal-poor lower nonlithophysal zone (Tptpln). The middle crystal-poor vitric zone (Tptpv2) has much lower mean Young's modulus (approximately 16.5 GPa), however the sample was taken from one borehole and interval. The lower strength from this limited sample is probably the result of the vitric nature of the rock and the higher porosity and presence of fracturing that are characteristic of the interior of the vitric zones. No samples were analyzed from the lowermost interval (Tptpv1).

\subsubsection{Older Tuffs}

Tables 5 and 6 also present static test results for the older tuffs that underlie the Topopah Spring Tuff. While these units are of limited engineering interest, these data are presented for completeness and some of the results are useful in evaluating the effects of test environmental conditions (e.g., temperature, saturation). These results are also useful in applying [?]the qualification criteria for the unqualified data. In general, these units have higher porosity and, as a result, lower Young's modulus values. Figure 14 illustrates the distribution of Young's modulus and Poisson's ratio for the Calico Hills Formation (Tac). 


\subsubsection{Effect of Temperature, Saturation, and Confining Pressure}

While most samples were tested at full saturation, room temperature, and unconfined compression, a number of samples were tested under other environmental conditions, in part, to determine the effects of saturation, temperature, and confining pressure on the elastic properties of the tuffs. In general, increased saturation and temperature are thought to decrease the strength of a sample (e.g., Price 1983a, pp. 10 to 11; Olsson 1982, p. 9), and thus the Young's modulus will be lower also. Test results from a relatively low porosity unit (Tptpmn, non-Busted Butte) under conditions of full saturation, room temperature and increasing confining pressure are illustrated in Table 9. Young's modulus was found to increase slightly when confining pressure was increased from atmospheric to $5 \mathrm{MPa}$, but then decreased below the value determined under atmospheric confining pressure when the confining pressure was increased to $10 \mathrm{MPa}$. The variation in Young's modulus results due to increasing confining pressures may have been influenced by variations in porosity and by the limited sample count.

A comparison of tests at full saturation, room temperature, atmospheric confining pressure to tests at full saturation, $150^{\circ} \mathrm{C}$, and atmospheric confining pressure show limited impact on elasticity from increased temperature (Table 10). Little impact on Young's modulus is also observed as confining pressure is increased at high temperatures. Data from Senseny and Mellegard (1987) from Busted Butte samples were used to corroborate the results and are included in Table 10. The effect of saturation, temperature, and confining pressure may be obscured by the low sample numbers, the variation in porosity of the lithostratigraphic unit being tested, the presence of fractures, and the presence or absence of lithophysae.

The following general conclusions can be drawn from the available data for Yucca Mountain tuffs:

- The lithology of the lithostratigraphic unit is more important than the effect of increasing temperature and saturation on the strength of the sample.

- Poisson's ratio and Young's modulus are affected only slightly by changes in saturation.

- The effect of both higher temperature and saturation with increasing confining pressure causes slightly lower Young's modulus.

\subsubsection{Effect of Test Specimen Size}

The effect of test specimen size on elastic properties was evaluated in Price (1986, p. 7). Although most tests performed on Yucca Mountain samples were run using 25.4 and 50.8-mm diameter samples, a few tests were run using larger diameter samples. The specimens represented in Tables 5 and 6 are all in the 25-64-mm diameter range with most samples being approximately 25.4 (one inch) or $50.8 \mathrm{~mm}$ ( 2 inches) in diameter. In nearly all of the testing that was conducted, sample length was twice the sample diameter. In the analysis reported in Price (1986), test specimens were obtained from outcrop samples of the Topopah Spring Member at Busted Butte. The samples ranged in diameter from 25.4 to $228.6 \mathrm{~mm}$, were water saturated, analyzed at room temperature, and deformed in compression at atmospheric confining pressure, at a nominal strain rate of $10^{-5} \mathrm{~s}^{-1}$. 
Results show Young's modulus and Poisson's ratio to be essentially independent of sample size at the scale of core samples (Table 11). While it is logical to assume that larger sample sizes may encounter a representative wider fracture spacing or frequency, the variations in lithology, porosity, and fracturing can generally explain the range and variation in elastic values observed.

\subsubsection{Effect of Test Drainage Conditions}

For confined triaxial tests, principal variables are confining pressure and whether the specimen was allowed to drain pore fluid during the test. Confining pressures are reported in DTN MO0304DQRIRPPR.002 as they are reported in the source. These are usually round numbers (e.g., 5, $10 \mathrm{MPa}$ ) that reflect the standard confining pressure values selected by the investigators for triaxial testing. Martin et al. (1995, p. 23) indicate that the test equipment was capable of maintaining the confining pressure within $\pm 0.1 \mathrm{MPa}$ of the selected nominal value for the duration of a test after the pressure initially stabilized.

While strength appears lower at higher confining pressures for the saturated tests, the same relationship is not evident for variations in Young's modulus. Under conditions of room temperature and increasing confining pressure, Young's modulus was found to increase slightly when confining pressure is increased from atmospheric to five MPa, but then decreases below that of the atmospheric confining pressure when the static confining pressure is increased to 10 $\mathrm{MPa}$. This suggests that regardless of whether the samples under static triaxial compressive tests are drained or undrained, the impact of confining pressure changes on Young's modulus may be minimal.

\subsubsection{Other Effects}

The effect of radiation on the mechanical properties of the Topopah Spring Tuff was studied in Blair et al. (1996). Samples of the Tptpmn unit from Fran Ridge were irradiated and compared with matched non-irradiated samples in uniaxial compressive strength tests. Blair et al. (1996, p. 10, Table 4) states that radiation had no significant effect on the elastic properties. Most of the samples behaved in a linear elastic manner up to the point of brittle failure, and that the Young's modulus for matched cores of irradiated and non-irradiated samples are very similar.

Summarized in Olsson and Jones (1980, p. 6-10) are mechanical properties from specimens obtained from drillhole UE 25 \#1 and from the Grouse Canyon welded tuff from G-tunnel. To determine the effect of strain rate on strength, a 100 percent saturated and an oven-dried specimen of Grouse Canyon welded tuff from G-tunnel were tested. The sample from G-tunnel is an irregular block on the order of 1-m on a side. Specimen diameters are $25 \mathrm{~mm}$ for the Grouse Canyon tuff and 48 and $64 \mathrm{~mm}$ for the Yucca Mountain tuff, all with length to diameter ratios of 2 to 1 or greater. The strength for both dry and wet welded tuff was found to decrease by 5 percent per decade of strain rate increase. The effect of confining pressure and strain rate on Young's modulus was minimal.

An interesting result presented by Olsson and Jones (1980, p. 6-10) is the apparent anisotropy of elastic moduli. They noted a significant difference in axial and transverse strain at a given pressure between the two directions. The variation increases as the degree of welding increases. While welded tuff is stiffest perpendicular to bedding, non-welded tuff is stiffest parallel to 
bedding. This difference is the result of the variation in porosity and crystallization during cooling. Thus the orientation of the sample collected may have an effect on the measured Young's modulus values.

The following general conclusions can be drawn from the available data on other effects for Yucca Mountain tuffs:

- Radiation had no significant effect on the elastic properties

- The effect of confining pressure and increasing strain rate on Young's modulus was minimal.

- Sample orientation relative to bedding may affect elastic properties.

\subsection{DYNAMIC POISSON'S RATIO AND YOUNG'S MODULUS}

This section summarizes the qualified and unqualified dynamic Poisson's ratio and Young's modulus data contained in DTN MO0304DQRIRPPR.002 by lithostratigraphic unit using standard measures from descriptive statistics. The data are reviewed to evaluate trends and distributions, to identify anomalies that require explanation, and to review the effects of different test environments on elastic behavior. The discussion concentrates on those units for which a sufficient number of tests were run to allow this type of review. Six DTNs were identified to contain dynamic elastic property data. One of the six DTNs (SNSAND91089400.000) was originally Qualified, but could not be verified, and will be included with the two unqualified DTNs (SNSAND83164600.000 and SNL02040687003.001) to be qualified in Section 5.

Shear and compressional wave velocities, Poisson's ratio, and Young's modulus were measured at four lithostatic stress levels in 49 core samples from borehole UE-25 UZ\#16 (PBT 1993, pp. 30-45). The data were extracted from the DTN GS940408312232.010. Young's modulus results from tests performed at $100 \mathrm{psi}(0.68 \mathrm{MPa})$ were compared with the results from other tests. Pulse velocity and ultrasonic elastic constants were also obtained from samples from drill hole UE25-NRG-1 for the Tpcpul and Tpcpmn units (McKeown, M. 1992, pp 128-130). In addition, dynamic elastic moduli were obtained for the Tptpmn layer from Busted Butte (Martin et al. 1992, pp. 8-14) and USW GU-3 borehole samples (Price et al. 1984, Table 10). These dynamic elastic property values are summarized in Tables 12 and 13. Most measurements were conducted on samples 1-inch in diameter and various lengths with the samples air dried (dry) at room temperature conditions. Bulk density values were estimated from sample weights and nominal volumes. The compressional and shear wave velocities of the samples were obtained by measuring the one-way travel time of a compressional or shear wave along the rock core axis, subtracting the travel time through the endcaps, and then dividing by the sample length.

Dynamic elastic properties of the samples were computed from the measured wave velocities and estimated bulk densities, with the assumption that the sample is isotropic, using the following equations (Martin et al. 1995, pp. 16-17):

$$
\begin{gathered}
\mathrm{E}=\left[\rho \mathrm{V}_{\mathrm{s}}^{2}\left(3 \mathrm{~V}_{\mathrm{p}}^{2}-4 \mathrm{~V}_{\mathrm{s}}^{2}\right)\right] /\left(\mathrm{V}_{\mathrm{p}}^{2}-\mathrm{V}_{\mathrm{s}}^{2}\right) \\
\mu=\left(\mathrm{V}_{\mathrm{p}}^{2}-2 \mathrm{~V}_{\mathrm{s}}^{2}\right) /\left[2\left(\mathrm{~V}_{\mathrm{p}}^{2}-\mathrm{V}_{\mathrm{s}}^{2}\right)\right]
\end{gathered}
$$


Where: $\quad E=$ Young's modulus of elasticity $\left(\mathrm{gm} / \mathrm{cm}^{2}\right)$

$$
\begin{aligned}
& \mu=\text { Poisson's ratio } \\
& \rho=\text { bulk density }\left(\mathrm{gm} / \mathrm{cm}^{3}\right)=(4 \mathrm{~W}) / \pi \mathrm{d}^{2} \mathrm{~L} \\
& \mathrm{~W}=\text { mass of test specimen } \\
& \mathrm{d}=\text { diameter of sample, } \mathrm{cm} \\
& \mathrm{L}=\text { sample length, cm } \\
& \mathrm{V}_{\mathrm{p}}(\text { compressional })=\mathrm{L}_{\mathrm{p}} /\left(\mathrm{T}_{\mathrm{p}}-\mathrm{C}_{\mathrm{p}}\right) \\
& \mathrm{V}_{\mathrm{s}}(\text { shear })=\mathrm{L}_{\mathrm{s}} /\left(\mathrm{T}_{\mathrm{s}}-\mathrm{C}_{\mathrm{s}}\right) \\
& \mathrm{p}=\text { compression wave } \\
& \mathrm{s}=\text { shear wave } \\
& \mathrm{C}=\text { transducer post travel times, at appropriate effective stress, sec } \\
& \mathrm{V}=\text { pulse propagation velocity }(\mathrm{cm} / \mathrm{sec}) \\
& \mathrm{L}=\text { sample length, cm } \\
& T=\text { total pulse travel time, sec }
\end{aligned}
$$

\subsubsection{Tiva Canyon Tuff}

Dynamic Poisson's ratio and Young's modulus measurement results for the Tiva Canyon Tuff (Tpc) at air dry and room temperature (T22) conditions are summarized in Tables 12 and 13. These tables show that there is significant variation between the lithostratigraphic units within the formation. The crystal-poor upper lithophysal (Tpcpul) and middle nonlithophysal (Tpcpmn) zones have higher Poisson's ratios (means of 0.322 and 0.292, respectively) and lower Young's moduli (means of 22.24 and $31.31 \mathrm{GPa}$, respectively) than the lower lithophysal and nonlithophysal zones. For the Tpcpll zone, the mean Poisson's ratio is 0.05 and the mean Young's modulus is $43.1 \mathrm{GPa}$. For the Tpcpln zone, the mean Poisson's ratio is 0.135 and the mean Young's modulus is $42.0 \mathrm{GPa}$. Part of the variation may be the result of the small sample sizes for the Tpcpll and Tpcpln intervals.

\subsubsection{Bedded Tuffs, Yucca Mountain Tuff, and Pah Canyon Tuff}

Dynamic Poisson's ratio and Young's modulus measurement results for the units below the Tiva Canyon Tuff (Tpc) and above the Topopah Spring Tuff (Tpt) are presented in Tables 12 and 13. These units consist of a series of bedded air-fall tuffs (Tpbt4, Tpbt3, and Tpbt2) and two thin ash-flow (ignimbrite) units, the Yucca Mountain Tuff (Tpy) and the Pah Canyon Tuff (Tpp). A limited number of tests were run at dry conditions and room temperature. The Pah Canyon Tuff 
(Tpp) was not tested. The results exhibit very low mean Young's modulus, ranging from 2.95 to 6.36 GPa. The mean Poisson's ratio for bedded air-fall tuffs ranged from 0.15 to 0.30 .

\subsubsection{Topopah Spring Tuff}

Dynamic Poisson's ratio and Young's modulus test results for the Topopah Spring Tuff (Tpt) are summarized in Tables 12 and 13. The Topopah Spring Tuff is zoned in a fashion similar to the Tiva Canyon Tuff. The upper crystal-rich nonlithophysal zone (Tptrn) has a relatively low Young's modulus (mean of $23.56 \mathrm{GPa}$ ) and a mean Poisson's ratio of 0.17 . As with the Tiva Canyon Tuff, the lower Young's modulus is probably the result of variations in the degree of crystallization, fracturing, and porosity development. The test results under dry conditions from boreholes and Busted Butte samples for the upper lithophysal (Tptpul) and middle nonlithophysal (Tptpmn) have higher Young's moduli (means of 30.03 and $43.36 \mathrm{GPa}$, respectively). Mean Poisson's ratios under dry conditions for the Tptpul and Tptpmn units are 0.112 and 0.195 , respectively. Under saturated conditions, Young's modulus test results for the Tptpmn unit were slightly lower (mean of $39.94 \mathrm{GPa}$ ). The mean Young's modulus test results at dry conditions and room temperature of borehole specimens for the underlying Tptpll and Tptpln units are 33.38 and $40.90 \mathrm{GPa}$, respectively. The range of values probably results from lithophysae occurring in varying proportions within the test specimens.

\subsubsection{Older Tuffs}

Tables 12 and 13 also present dynamic test results for the older tuffs that underlie the Topopah Spring Tuff. These include the tuffaceous units of the Calico Hills (Tac) and the Prow Pass member of the Crater Flat Tuff (Tcp). In general, these units have higher porosity and, as a result, lower Young's modulus values (means of 14.35 and $17.66 \mathrm{GPa}$, respectively, under dry conditions). Mean Poisson's ratios for these two intervals are 0.13 and 0.183 , respectively. The negative minimum value for the Tcp member appears anomalous and may be explained by variation in porosity causing higher shear wave velocity resulting in a negative Poisson's ratio.

\subsubsection{Effect of Confining Pressure}

The effect of increasing confining pressure on elastic constants was evaluated by PBT (1993, pp. 30-45). Testing was performed on 49 core samples from selected lithostratigraphic units of the Tiva Canyon Tuff, Pah Canyon Tuff, Topopah Spring Tuff, Calico Hills Formation, and the Prow Pass Member of the Crater Flat Group. Many intervals only had one or two specimens tested. Compressional and shear wave measurements were made on each air-dried sample at 100 psig, 300 psig, 600 psig, and 1000 psig (0.68 to $6.89 \mathrm{MPa}$ ), and back to 100 psig confining pressure while holding pore pressure at 0 psig (PBT 1993, p. 3). On the water saturated samples, confining pressures and pore pressure values were both increased by $200 \mathrm{psig}(1.38 \mathrm{MPa})$. Note that the effective stress is the difference between confining pressure and pore fluid pressure. Plots of velocity squared versus effective stress to the $1 / 3$ power were made for each sample to characterize the relationships between effective stress and wave velocity.

The results of the shear wave testing illustrate the effect of confining pressure on computed elastic properties. The tests produced similar kinds of results independent of lithostratigraphic unit or lithology. Test results on air dry samples showed that Poisson's ratio generally increased 
slightly (5 percent to 10 percent) as confining pressure was increased from 100 psig to 1000 psig $(0.68$ to $6.89 \mathrm{MPa})$. However, test results on water saturated samples showed that Poisson's ratio decreased by over 5 percent as confining pressure was increased. Young's modulus values from tests on air dry and water wet samples increased from 2 percent to over 20 percent as confining pressure increased from 100 psig to 1000 psig (0.68 to $6.89 \mathrm{MPa})$.

\subsubsection{Comparison of Seismic Wave Testing and Uniaxial Compression Tests}

The results of seismic wave testing on samples from UE-25 UZ\#16 were compared to those obtained by uniaxial compression tests in the same lithostratigraphic units from other boreholes. No uniaxial compression tests were performed on samples from the UE-25 UZ\#16 borehole. Poisson's ratio of the lithophysal and nonlithophysal zones obtained from compression tests were generally 50 percent to 100 percent greater than those obtained by shear wave testing. Poisson's ratio values of the bedded tuff intervals from compression tests were generally similar to slightly lower than those from the shear wave tests. Young's modulus of the lithophysal and nonlithophysal zones obtained from compression tests were approximately 20 percent lower than those obtained by shear wave testing (values converted to GPa). Young's modulus values of the bedded tuffs from compression tests were also considerably lower than those obtained by shear wave testing. Due to the variation in Poisson's ratio and Young's modulus values, the results from these two different testing methods were not combined and will be reported separately.

Similar results on Busted Butte samples were observed by Martin et al. (1993, pp. 9-12). Experiments were conducted on water-saturated specimens $50.8 \mathrm{~mm}$ in diameter and $101.6 \mathrm{~mm}$ in length from the Tptpmn lithostratigraphic unit. Prior to the mechanical tests, compressional and two orthogonally polarized shear wave velocities were measured parallel to the core axis for both dry and saturated conditions. These data were used to compute dynamic elastic moduli and compared to the static moduli collected in the low strain rate deformation tests. For the dry samples dynamic Poisson's ratio values ranged from 0.20 to 0.21 and Young's modulus ranged from 40.83 to $44.25 \mathrm{GPa}$. For saturated samples, dynamic Poisson's ratio ranged from 0.23 to 0.28 and Young's modulus ranged from 38.52 to $45.34 \mathrm{GPa}$. This compares to a range in Poisson's ratio of 0.01 to 0.16 and a range in Young's modulus of 26.1 to $38.8 \mathrm{GPa}$ for saturated specimens under static uniaxial compression tests. Although the dynamic elastic moduli values differ substantially from the static elastic moduli, the relative magnitude of the values is generally consistent within each method.

\subsubsection{Downhole Seismic Survey Measurements}

The means and standard deviations of Poisson's ratio values from downhole seismic surveys in boreholes in the vicinity of Yucca Mountain are presented in Table 14. The data were extracted from the qualified DTN MO0204SEPBSWHB.001. The data are not used for corroboration, but included for completeness of the parameter evaluated. Qualified geologic data from eight "deep" boreholes and eight "shallow" boreholes were used to determine rock types, bedding characteristics, and lithostratigraphic information. Deep boreholes extend a minimum of 100 feet into bedrock that has a shear wave velocity of at least $5,000 \mathrm{ft} / \mathrm{s}$; shallow boreholes extend a minimum of 50 feet into the densely welded Tiva Canyon Tuff. The various geophysical survey data were used to construct profiles of shear and compressional wave velocity to develop ground motion parameters and perform geotechnical evaluations in the area. 
The range of variation of shear and compressional wave velocity versus spatial location may be a function of horizontal location as well as depth below ground surface due to the dip of the strata and the presence of faults with vertical offset of strata. Thus the calculated elastic properties from the seismic surveys may not be accurately correlated to the specific lithostratigraphic zones identified in cored boreholes or surface samples. Since these values are a different type of data than the static and dynamic Poisson's ratio values, the mean Poisson's ratio results are reported separately in Table 14 .

\section{DATA QUALIFICATION APPROACH}

The Data Qualification Team used the qualification method of corroboration to qualify the data. The corroborating data method was used in comparing different data sets to evaluate the consistency of independently acquired data. The qualification method was applied in the following manner:

An initial evaluation of the data quality and correctness was performed. The team evaluated the data by comparing the methods used to plan, collect, and analyze the data against generally accepted scientific and engineering practices. The employed practices or procedures must demonstrate industry acceptable scientific, engineering, or administrative practices or processes with appropriate compliance documentation. When the evaluation determined that the data were adequate, corroboration was used to qualify the data.

The Corroborating Data approach may be used when subject matter data comparisons can be shown to substantiate or confirm parameter values. As stated in AP-SIII.2Q, Attachment 2, the corroborating data qualification process may include comparisons of unqualified to unqualified data, as well as unqualified to qualified data.

The following are conditions for the use of corroborating data:

a. Sufficient quantity of corroborating data are available for comparison with the unqualified data set(s).

b. Inferences drawn to corroborate the unqualified data can be clearly identified, justified, and documented.

\subsection{EVALUATION CRITERIA}

The following five criteria identified in the Technical Work Plan for evaluating the qualification status of the Intact Rock Properties data are listed below. These criteria were selected to incorporate the considerations in AP-SIII.2Q, Attachment 2; the applicable qualification process attributes listed in Attachment 3; and data-specific considerations identified in Section 3 of this report.

1. Are the data collection methods reasonable in view of standard measurement and instrumentation practice at the time the data were collected? 
2. Are the qualifications of the personnel or organizations generating the data comparable to qualification requirements of personnel generating similar data under the approved 10 CFR 63, Subpart G quality assurance program?

3. Are these data, or similarly collected data, generally accepted by the technical community for use in non-YMP applications?

4. Does analysis of comparable qualified and unqualified data sets indicate a reasonable level of accuracy for the testing?

5. Is the documentation associated with the data sufficient to allow an assessment of the methods used and the result obtained?

\subsection{RECOMMENDATION CRITERIA}

A recommendation for qualification is based on the satisfactory resolution of one or more of the evaluation criteria. Although these criteria have been considered in determining whether the status of the data should be changed to qualified, the final conclusions of the Data Qualification Team are based on the preponderance of evidence, and not all of the qualification criteria were necessarily applied.

\section{DATA QUALIFICATION EVALUATION RESULTS}

The unqualified data that were used in compiling DTN MO0304DQRIRPPR.002 were collected by national laboratories, USGS, or a group of commercial laboratories that were contracted by the national laboratories. Most of these data sets were unqualified because the work was completed before the acceptance of the OCRWM QA program in 1989. Three of the DTNs had their status changed from qualified to unqualified and are included in this evaluation. The documentation and methods used by each of the laboratories will be reviewed first and then a comparison of the data sets will be made.

\subsection{SANDIA NATIONAL LABORATORIES}

Most of the unqualified data considered in this report were either generated by Sandia National Laboratories (SNL) or a subcontractor to SNL. This section considers the testing carried out in SNL facilities. Table 15 lists the unqualified SNL DTNs that were reviewed to compile DTN MO0304DQRIRPPR.002. All of these sources are unqualified because the work was completed prior to 1989. Table 15 also identifies the significant records or records packages that document the collection of the data. The record listing is not meant to be complete, but shows those records that are judged to be significant in evaluating the quality of the data. All of the SNL data are quite well documented. Each DTN has an accompanying report that provides an overview of the testing process. In addition, each DTN has an accompanying records package(s) that documents the testing process. Some record sets are relatively complete, with records showing the raw test data, calibrations, plots of the raw data, and final testing results. Other record sets are less complete and may consist of data summary forms prepared sometime after testing was completed. 
Static testing at SNL was performed on load frames having maximum load capacities of $1.0 \mathrm{MN}$, 1.8 MN, or 5.0 MN depending on the nature of the test. A constant loading rate of the piston was achieved by a servo-control of the hydraulic loading ram while monitoring a linear variable displacement transformer (LVDT) at the base of the loading column. Axial strains were calculated by averaging the measured displacements on two diametrically opposed LVDTs mounted directly on the sample. Lateral (transverse) displacements were measured across one sample diameter by a disk gauge. The reports and records indicate that the test system load cells were calibrated once a year against a standard transducer that is traceable to the National Bureau of Standards. The axial displacement LVDTs and disk gauges were calibrated with a standard micrometer (also traceable to the National Bureau of Standards) prior to each test series. The results of these calibrations appear in the reports and in the records packages.

In addition to the calibration of components, the entire testing system was calibrated by testing an aluminum cylinder of known mechanical properties. These system calibration tests were usually completed both before and after a test series. The results of these tests are also documented in the reports and records packages.

Price (1983b) compared the SNL mechanical testing procedures in use at the time with the relevant testing standards then in place. He concluded that there were no applicable exceptions in the SNL procedures to the standards and that the SNL procedures met or exceeded the requirements of the ASTM standard procedures. Equipment, staff, training, and procedures did not significantly change between the pre-1989 testing (unqualified) and the post-1989 testing (qualified from origin). SNL currently has an OCRWM-approved QA program.

SNL performed dynamic tests on specimens from drillhole USW GU-3. Samples were nominally $25.4 \mathrm{~mm}$ in diameter, $50.8 \mathrm{~mm}$ in length, and 100 percent water saturated. Dynamic tests results were compared to static tests at atmospheric confining pressure, room temperature, and nominal strain rate of $10^{-5} \mathrm{~s}^{-1}$. These samples were tested for P- and S-wave velocities in three orthogonal directions using a benchtop apparatus similar to that used by NER. From these velocities, Young's modulus and Poisson's ratio were calculated.

SNL is a highly regarded government laboratory and the quality of their work is widely accepted in the scientific community. The SNL employees who performed the dynamic tests are the same highly trained and experienced individuals that perform similar analyses under OCRWM QA standards and procedures. Equipment, staff, training, and procedures did not significantly change between the pre-1989 testing (unqualified) and the post-1989 testing (qualified from origin).

\section{$5.2 \mathrm{RE} / \mathrm{SPEC}$ INC.}

RE/SPEC Inc. was used as a subcontract laboratory by SNL on two occasions (SNL02033084002.001 and SNL02072983003.001) during the 1980s for compressive strength testing. RE/SPEC is a commercial laboratory located in Rapid City, South Dakota, that specializes in rock mechanics testing and other geotechnical services. The major supporting records for these data sets are identified in Table 15. The results are well documented with a contractor's report, raw data files, and/or data plots available for all the tests. 
A full set of the standard procedures used by the RE/SPEC laboratory for static tests is available in the RPC. In addition, the contractor reports give a description of the special requirements that were applied to the tests due to SNL requirements. The equipment used was a load frame that could apply an axial load of 4.5 MN. The system was equipped with a pressure vessel that allowed triaxial testing to $140 \mathrm{MPa}$. Axial load was measured by a load cell inside the pressure vessel and confining pressure and pore pressure were measured by transducers. Temperature was measured by a thermocouple inside the pressure vessel adjacent to the specimen. Specimen deformation was measured by a set of transducers. The load, pressure, temperature, and deformation transducers were calibrated at ambient pressure and temperature using the standard RE/SPEC laboratory procedures and standards traceable to the National Bureau of Standards. The contractor reports provide information on the calibration results.

In addition to calibration of test apparatus components, the operation of the entire system was tested using aluminum cylinders of known properties, according to SNL procedures. The results of the test runs are also documented in the contractor reports. For elevated temperature tests, the system was also tested using a steel blank at both room and elevated temperatures. The tests indicated that Young's modulus and Poisson's ratio could be determined within about 3 percent of the known value for the test specimens.

$\mathrm{RE} / \mathrm{SPEC}$, Inc. is an established commercial laboratory, and the quality of its work is widely accepted in the scientific community for use in non-YMP applications. RE/SPEC has highly trained and experienced technicians capable of performing the mechanical tests to proper procedures. Although the work was not performed under an OCRWM-approved QA program, the qualification team has judged that this laboratory could have had its QA programs accepted without major difficulty.

\subsection{NEW ENGLAND RESEARCH, INC.}

New England Research, Inc. (NER) conducted static and dynamic testing for two unqualified DTNs (SNSAND91089400.000 and SNL02040687003.001). NER operated as an SNL subcontractor for this work. NER is a commercial laboratory in White River Junction, Vermont, that performs laboratory rock properties measurements. Their primary business is using laboratory core measurements and modeling techniques for oil, gas, and geothermal reservoir evaluations. The major supporting records for these data sets are identified in Table 15. The results are well documented with an SNL report, raw data files, and a procedure for static unconfined uniaxial compression experiments.

The procedure for static tests was approved by SNL and was tailored for the specific test documented in the DTN SNL02040687003.001. The apparatus for static testing consisted of a loading frame, a servo-controller, and a data acquisition system. The capacity of the press was 6.7 MN. Specimens were tested in a pressure vessel with a pressure capacity rating of $50 \mathrm{MPa}$. Data were generated by a load cell measuring the force on the test column, LVDTs measuring axial and radial displacements of the specimen, and a thermocouple. The calibration and testing process was similar to that used by SNL. The system was calibrated using an aluminum test specimen of known properties that was tested before and after each tuff test. The results of these calibrations are included in the documentation and indicate that the apparatus was yielding 
consistent results for the Young's modulus and Poisson's ratio of the aluminum standard that agreed with published values.

NER performed dynamic testing of Young's modulus and Poisson's ratio for comparison with the static test results. The compressional and shear wave velocities were measured in a benchtop apparatus that applied an axial stress of approximately $0.4 \mathrm{MPa}$ to the specimen. The wave velocities of the samples were obtained by measuring one-way travel time along the rock core axis and then dividing by the sample length. The source transducers are in a piston used to load the sample and the receiver transducers are located in the base of the apparatus. The source crystal is excited by a fast rise time electrical pulse generated with a pulsar/receiver. The crystal produces a broadband (300 to $800 \mathrm{kHz}$ ) ultrasonic pulse that propagates through the adjacent titanium end piece, through the rock sample along the core axis, through the titanium end piece at the opposite end of the core, and into the crystal receiver. The electrical signal produced by the receiver crystal is amplified and filtered by the receiving section of the pulsar/receiver, then fed into a digital oscilloscope. The oscilloscope digitizes the ultrasonic waveform and displays the digitized signal. The travel times are determined by picking the point at which the threshold voltage is exceeded relative to the baseline voltage. The resolution of the pick is $+/-0.01$ millisecond. The dynamic Young's modulus and Poisson's ratio were computed from the travel time data.

Calibration checks were performed by on a specimen of 6061-T6511 aluminum, machined to the same dimensions as the tuff samples $(50.8 \mathrm{~mm}$ in diameter and $101.6 \mathrm{~mm}$ in length). For aluminum, the dynamic and static moduli should agree since there is no porosity. The dynamic Young's modulus was $71.02 \mathrm{GPa}$ and Poisson's ratio was 0.34 for the aluminum standard. This compares closely to the mean values from seven static calibration tests of Young's modulus (70.56 GPa, standard deviation of 0.504 ) and mean Poisson's ratio of 0.34 (standard deviation of 0.005 ) for the same aluminum standard.

The NER QA program was subsequently accepted by SNL and the YMP (e.g., Hawkinson 1993, Hawkinson and Richards 1994, SNL 1999a, and SNL 1999b) and NER produced qualified data similar to the unqualified data using basically the same staff, procedures, and equipment.

\subsection{TERRA TEK, INC.}

Terra Tek, Inc. is a geotechnical engineering company located in Salt Lake City, Utah, that provides commercial rock mechanics testing and core analysis to the oil and gas industry and other clients. The company served as a subcontractor to SNL and provided testing that was the source for several unqualified DTNs (SNL02072983001.001, SNSAND82105500.000, SNSAND84110100.000, and SNSAND85070300.000). The major supporting records for these data sets are identified in Table 15. The results are well documented with SNL or contractor reports, raw data files, and procedures available for each DTN.

Static testing was carried out on load frames with a servo-controlled loading piston operating at a constant displacement rate. As with the other laboratories, loading was measured with an LVDT mounted at the top or bottom of the loading column. Axial strains and lateral displacements were measured with other LVDTs. The test system load cell was calibrated annually against a standard transducer. The axial displacement LVDTs and transverse displacement gauges were calibrated 
with a standard micrometer head prior to a test series (Van Buskirk et al. 1984, p. 8). As with the other tests contracted by SNL, the entire system was calibrated using an aluminum sample of known properties before and after each test series. The results of these system calibrations are documented in the records listed in Table 15. The calibrations indicated that the known value was reproduced to within 1.3 to 1.8 percent for Young's modulus and 3.0 to 4.5 percent for Poisson's ratio (Van Buskirk et al. 1984, p. 5; Nimick et al. 1985, Figure 2).

Terra Tek is an established commercial laboratory, and the quality of its work is widely accepted in the scientific community for use in non-YMP applications. Terra Tek has highly trained and experienced technicians capable of performing the mechanical tests to proper procedures. Although the work was not performed under an OCRWM-approved QA program, the qualification team has judged that this laboratory could have had its QA programs accepted without major difficulty.

\subsection{BUREAU OF RECLAMATION}

One data set, DTN GS921283114220.009, listed in Table 15 was generated by the U.S. Bureau of Reclamation (USBR) working in support of studies conducted by the USGS. These data were developed from triaxial testing completed on core from the UE-25 NRG-1 borehole. The data were originally identified as qualified and not verified in TDMS. However, the verification review conducted under AP-3.15Q found that there were difficulties in verifying the calculations of elastic properties for specimens from the triaxial tests. As a result, the status of this DTN was changed to unqualified.

The records listed in Table 15 provide documentation of the testing process. The tests were conducted in accordance with ASTM D-2664-86. The records contain a summary sheet showing test results, sample preparation information, calibration results, and, for each test, a plot of the test, a summary sheet, a record of test settings, and raw data printouts. The test system was calibrated by using an aluminum cylinder in a process that was similar to the method used in the SNL testing. During the verification of those data, the calculation of Poisson's ratio and Young's modulus could not be recreated. The values reported did not fit within the range of similar analyses performed by USBR on the same borehole and depths under qualified DTN GS921283114220.008. The unqualified values from DTN GS921283114220.009 were therefore not included in Tables 5 and 6 or in the summary DTN MO0304DQRIRPPR.002, and will not be further evaluated for qualification in this report.

\subsection{COMPARISON OF DATA SETS}

To apply the corroborating data qualification method, this section makes comparisons between qualified and unqualified data and comparisons between data generated by different laboratories under similar measurement techniques for select lithostratigraphic intervals. The intervals selected for comparison are generally those in the middle and lower portions of the stratigraphic column that have been tested by several laboratories and have a sufficient number of tests for the comparison to be meaningful given the variation with lithostratigraphic units. In reviewing the comparisons, it should be noted that the samples being tested are not identical and may come from different boreholes and/or different stratigraphic levels within the same lithostratigraphic unit. 


\subsubsection{Topopah Spring Tuff}

Several comparisons can be made between the various laboratories and between qualified and unqualified data using the static testing results for the Topopah Spring. The measurements on outcrop samples from Busted Butte for unit Tptpmn are a good case because all the samples came from the same location and many came from the same sample block. Specimen size varied from $25.4 \mathrm{~mm}$ to $228.6 \mathrm{~mm}$ in diameter. Most of these data are unqualified. While most of the tests were completed by SNL, testing was also done by NER, RE/SPEC, and Terra Tek. The saturated Poisson's ratio results for unit Tptpmn from boreholes and Busted Butte samples for Terra Tek and SNL (Table 16) fall in the same range and corroborate each other. The same can be said for the unsaturated Busted Butte sample analyses from NER and SNL (Table 17). This is in contrast to the Poisson's ratio mean and median from Busted Butte samples analyzed by $\mathrm{RE} / \mathrm{SPEC}$ which are significantly lower than the results from the other labs for saturated and dry samples. The values from RE/SPEC are skewed due to a few very low values that may have encountered fractures or lithophysae that affected elastic property measurements.

Comparisons of Young's modulus values for saturated samples of Tptpmn from Busted Butte (Table 18) show that mean and median values from SNL are higher than those from RE/SPEC or Terra Tek. This is due to several large values (greater than $45 \mathrm{GPa}$ ) that skewed the results higher for SNL and a couple of low RE/SPEC values (less than $20 \mathrm{GPa}$ ). Young's modulus values from boreholes for NER and SNL are similar. The Terra Tek samples are from one well over a limited number of intervals. Comparison of unsaturated results (Table 19) shows that mean and median values from NER and SNL from the ESF are similar. The high values from Busted Butte for NER are affected by the small sample size. An important observation is the close agreement between unsaturated RE/SPEC and SNL for Busted Butte samples. The fact that most of the Poisson's ratio and Young's modulus values from NER, RE/SPEC, and Terra Tek fall within the range of the qualified and unqualified values from SNL implies that it is not the analysis techniques or procedures at the various laboratories that were the cause of the differences in results. The differences are possibly due to lithologic variation of the individual samples analyzed or the environmental conditions used in the analysis. Each set of results basically corroborates the general picture of variation in elastic properties in this unit.

The qualified and unqualified test results for the Tptpmn zone from borehole and Busted Butte sample locations for all laboratories can also be compared. Tables 20 and 21 of Poisson's ratio values show an excellent agreement between the three data sets. Similar agreement of Young's modulus values between qualified and unqualified values can be seen in Tables 22 and 23. The major difference is that Young's modulus values from saturated and unsaturated Busted Butte samples tend to have a slightly higher mean than borehole and ESF values.

Young's modulus results for a lithophysal unit can also be compared to determine if the wide range of results noted above are driven by the results from a single laboratory or are supported by the results from several laboratories. Table 24 compares the results from qualified (NER) and unqualified (SNL and Terra Tek) sources for the Tptpll zone. Although there is a difference in the number of tests, each laboratory found a wide range of values for Young's modulus, showing that the variation is not the result of differences between laboratories. Each set of results basically corroborates the general picture of variation in elastic properties in this unit. Similar results by laboratory can be seen for the Tptpln zone as well as the Tptpmn zone. 
Dynamic results for Young's modulus and Poisson's ratio from the Tptpmn can also be compared among the several laboratories performing dynamic tests. While most of the tests were completed by SNL on saturated specimens, testing was also done by NER and USBR. USBR results are qualified, while SNL and NER results are unqualified. In order to allow comparisons, only the initial values measured at $100 \mathrm{psi}(0.68 \mathrm{MPa})$ from USBR from the Tiva Canyon to the base of the Topopah Springs were used in Tables 12 and 13.

Dynamic Poisson's ratio results in Table 25 from dry, room temperature conditions for USBR and NER specimens exhibit some differences. USBR has a much lower mean, and lower minimum and maximum values. There are several reasons why the results vary. USBR specimens were from various depths in the UE-25 UZ\#16 wellbore and were measured at various confining pressures (only the $100 \mathrm{psi}(0.68 \mathrm{MPa})$ values were used in the table). NER samples were taken from a sample block from Busted Butte. Specimen sizes also varied with most NER specimens twice the diameter of USBR specimens. The differences in specimen lithology and size could account for much of the variation.

Dynamic Poisson's ratio results from saturated samples from NER and SNL are very similar (Table 25). NER samples are from Busted Butte, while SNL samples are from the USW GU-3 borehole. The diameter of the specimens from NER are twice those from SNL. While the number of samples from SNL is much larger than NER, the NER values generally fit within the range of SNL results.

Dynamic Young's modulus results from USBR and NER from dry specimens under room temperature conditions are similar (Table 26). The differences in means (40.70 versus 44.12 $\mathrm{GPa}$ ) could be accounted for by the small sample count, the difference in where the samples were collected, difference in sample size, and variation in lithology. There is also close agreement in mean Young's modulus and the range of values between the saturated Butted Butte specimens from NER and the saturated borehole specimens from SNL.

\subsubsection{Calico Hills Formation}

A comparison of the results for the Calico Hills Formation from NER and SNL shows close agreement in Poisson's ratio (means of 0.31 and 0.27 , respectively) and Young's modulus (means of $6.4 \mathrm{GPa}$ and $6.5 \mathrm{GPa}$, respectively). The results from NER are from a qualified source and the results from SNL are from unqualified sources. Although there are small sample sizes, the results show very good agreement between the sources for this unit.

\subsubsection{Prow Pass and Bullfrog Tuffs}

Uniaxial compressive strength analyses were performed by SNL on the various lithostratigraphic tuff units that underlie the Calico Hills Formation. Due to the fact that there are small numbers of analyses performed and only unqualified values are available from only a few DTNs, no comparison of values was performed. However, these analyses were performed at the same time and manner as those from the undifferentiated Calico Hills and Tram Tuff units, which showed good agreement between laboratories. The variability in lithology is evident in each of the units. 


\subsubsection{Tram Tuff}

The results from two different laboratories were compared for the upper vitric zone of the Tram Tuff (Tctuv). All of these data are unqualified. There is general agreement between the mean SNL results (Poisson's ratio of 0.14) and mean Terra Tek results (Poisson's ratio of 0.17). Corresponding values for Young's modulus are 10.4 GPa for SNL and 13.9 GPa for Terra Tek. Whether this represents an actual difference between laboratories or is just result of relatively small sample size and lithologic variability is difficult to identify. However, a consistent bias is not evident when these results are compared to the Calico Hills Formation (Tac) where the SNL and NER results show good agreement.

\subsubsection{Unqualified Corroborating Data}

DTN LL990205304243.032 was originally identified as qualified but unverified in the TDMS. However, the verification review conducted under AP-3.15Q found that no records documenting the laboratory testing were available, and the status of the DTN was therefore changed to unqualified. The main documentation for this DTN is contained in an LLNL report (Blair et al. 1996).

Blair et al. (1996, p. 2-7) indicate that the testing was done to determine the effects of radiation on uniaxial compressive strength. The samples were of the Topopah Springs Tuff from an outcrop at Fran Ridge, Nevada Test site. The uniaxial testing was conducted in accordance with the applicable portions of ASTM procedures D-2664-86, D-2938-86, D-3148-86, and D-454385. Samples were cored from an outcrop sample and then cut and ground to achieve the desired diameter and length $(25.4$ by $76.2 \mathrm{~mm})$. Core size and core end parallelism were then measured with digital calipers and other equipment. The test apparatus consisted of a 100-ton-capacity reaction frame with a 50-ton hydraulic ram, strain gauged load cells for axial displacement, and direct current displacement transducers. Test data were recorded on an Apple Macintosh computer using a LabView version 3.1 routine. Blair et al. (1996) contains no information on how this system was calibrated or tested. The values obtained are also significantly lower than those values obtained from Busted Butte or boreholes that could be caused by the testing technique or sample lithology. Therefore, due to the lack of laboratory testing records and the questionable comparison of values from Fran Ridge to those from Busted Butte and available borehole data, the values from DTN LL990205304243.032 were not incorporated in Tables 5 and 6 or in the summary DTN MO0304DQRIRPPR.002, and will not be further evaluated for qualification in this report.

\section{DATA QUALIFICATION EVALUATION CONCLUSIONS}

The conclusions from the Data Qualification Team's review of the unqualified Poisson's ratio and Young's modulus data included in DTN MO0304DQRIRPPR.002 are presented below in terms of the five evaluation criteria presented in Section 4.1.

1. Are the data collection methods reasonable in view of standard measurement and instrumentation practice at the time the data were collected? 
The review in Section 5 and the records listed in Table 15 demonstrate that the testing methods used to generate the data are well documented, represent good practice, and were in general conformance with the applicable testing standards (e.g., ASTM) in place at the time. The use of a total system calibration test using an aluminum sample of known properties before and after most tests adds confidence that the mechanical systems, recording sensors, software, and data reduction processes were operating correctly for these tests.

2. Are the qualifications of the personnel or organizations generating the data comparable to qualification requirements of personnel generating similar data under the approved 10 CFR 60, Subpart G QA program?

The organizations generating the data are judged to meet the qualification requirements for generating data under a 10 CFR 60, Subpart G QA program. SNL, NER, LLNL, and the USGS/USBR have accepted QA programs in place that use basically the same staff, training, procedures, and equipment that were used for the unqualified testing. Terra Tek and $\mathrm{RE} / \mathrm{SPEC}$ are established commercial laboratories that specialized in this type of work. They each performed the analysis to SNL and ASTM established procedures. Although the work was not performed under a OCRWM-approved QA program, the qualification team has judged that these laboratories could have had their QA programs accepted without major difficulty.

3. Are these data, or similarly collected data, generally accepted by the technical community for use in non- YMP applications?

Uniaxial and triaxial compressive strength testing are industry standard tests that are used in civil, mining, and oil and gas projects. The testing procedures have a long and extensive history of development and use and are not considered experimental or unique. The calculation of Young's modulus and Poisson's ratio from the compressive strength testing and compressive and shear wave velocity measurements use widely established and followed regression techniques. The commercial laboratories being evaluated routinely conduct this type of testing for industry clients. The products of these laboratories are widely accepted by the engineering and technical community for other projects.

4. Does analysis of comparable qualified and unqualified data sets indicate a reasonable level of accuracy for the testing?

The comparisons discussed in Section 5.6 indicate that the qualified or unqualified data generated by different laboratories for the same lithostratigraphic unit and tested under similar conditions yield very similar range of results. Such comparisons must be tempered with the knowledge that the various laboratories were not testing the same specimens and the substantial variation within a particular lithostratigraphic unit will result in substantial scatter in every comparison. This factor means that the number of samples tested is important in evaluating these comparisons. Laboratories that conducted a smaller number of tests should not be expected to precisely reproduce the distributions seen from sources that completed a larger number of tests. With these restrictions in mind, the comparisons indicate that there are no substantial differences between data sets that were collected under a 10 CFR 63, Subpart G, program and those that were not. In addition, the comparisons between 
unqualified data collected independently by different laboratories are mutually corroborative in the sense that each source produced data that would fall within the range of results from the other sources.

5. Is the documentation associated with the data sufficient to allow an assessment of the methods used and the results obtained?

As discussed in Sections 5.1 to 5.6 and documented in Table 15, each of the unqualified sources has substantial documentation on the procedures used and the data obtained. Except for the LLNL data discussed in Section 5.6.5 and not considered in this qualification,, the sources have test system calibration information for the equipment used. In most cases, the documentation is comparable to the critical documents that would be expected for a qualified program.

It is the general conclusion of the Data Qualification Team that the unqualified data used in the compilation of DTN MO0304DQRIRPPR.002 meet the evaluation criteria. This does not mean that all the data sets uniformly meet the evaluation criteria. However, the relatively complete reports and excellent corroboration by independent data sets were found by the team to provide sufficient basis for qualification. The team also noted some variation in the detail of supporting records available for some tests. However, the qualification team feels that the preponderance of evidence from the records, calibration testing, and comparisons between independent data sets supports the conclusion that these data are qualified for use.

\section{RECOMMENDATIONS}

The Data Qualification Team found that the static and dynamic Young's modulus and Poisson's ratio data compiled in DTN MO0304DQRIRPPR.002 and summarized by lithostratigraphic unit in Tables 5, 6, 12, 13, and 14, are qualified for use by the YMP based on the results of the evaluations in Sections 5 and 6. The qualified and unqualified data used to compile DTN MO0304DQRIRPPR.002 were found to be of comparable quality and to adequately represent the properties of the samples tested. The unqualified data were found to be corroborated by other data sets through a comparison of standard descriptive statistical measures (e.g., mean, standard deviation, range) as discussed in Section 6 and illustrated in Tables 16-26. Since the different testing methods (compressive testing, shear wave, and downhole seismic survey) base the calculation of the elastic properties on different rock characteristics (compressive strength versus seismic wave velocity), the results from these techniques were not combined and are reported separately. The results from the static compressive strength tests in Tables 5 and 6 and the dynamic seismic wave testing in Tables 12, 13, and 14 yield the most stratigraphically complete data set of Poisson's ratio and Young's modulus values intended for use in the License Application design and safety analysis.

The major stratigraphic units at Yucca Mountain (e.g., Topopah Spring Tuff) are large ignimbrite flows that by their nature can be heterogeneous. Individual cooling units within the flow (e.g., Tptpmn and Tptpll) that have been differentiated based on lithologic properties are still subject to localized variations in porosity, the density of lithophysae, minor fracturing, alteration, and the amount and composition of lithic inclusions. These variations can have significant impact on test 
results. Therefore, how one defines intact or rock mass properties may affect how the results presented in Tables 5, 6, 12, 13, and 14 and in DTN MO0304DQRIRPPR.002, are viewed.

These summaries and supporting information and discussions have been included in a RIB Data Item, which summarizes the qualified values for the intact rock properties evaluated in this report. Depending on their need, data users may use individual test results from DTN MO0304DQRIRPPR.002 or the summarized data in the RIB Data Item. In either case, users must consider the impact of stratigraphic and lithologic variability, the variability in environmental testing conditions, and the various methods used in collecting the elastic property data in applying these results to specific problems.

\section{REFERENCES}

\subsection{DOCUMENTS CITED}

Blair, S.C.; Kelly, J.M.; Pine, O.; Pletcher, R.; and Berge, P.A. 1996. Effect of Radiation on the Mechanical Properties of Topopah Spring Tuff. UCRL-ID-122899. Livermore, California:

Lawrence Livermore National Laboratory. ACC: MOL.19961021.0132.

Boyd, P.J.; Price, R.H.; Noel, J.S.; and Martin, R.J. 1996. Bulk and Mechanical Properties of the Paintbrush Tuff Recovered from Boreholes UE25 NRG-4 and-5: Data Report. SAND94-2138. Albuquerque, New Mexico: Sandia National Laboratories. ACC: MOL.19970102.0004.

Brady, B.H.G. and Brown, E.T. 1993. Rock Mechanics for Underground Mining. $2^{\text {nd }}$ Edition. Boston, Massachusetts: George Allen \& Unwin. TIC: 245254.

BSC (Bechtel SAIC Company) 2002. Technical Work Plan for: Qualification of Intact Rock Properties Data on Poisson's Ratio and Young's Modulus. TWP-MGR-GE-000002 REV 00. Las Vegas, Nevada: Bechtel SAIC Company. ACC: MOL.20020923.0162.

BSC (Bechtel SAIC Company) 2003. Technical Work Plan for: Qualification of Intact Rock Properties Data on Poisson's Ratio and Young's Modulus. TWP-MGR-GE-000002 REV 01. Las Vegas, Nevada: Bechtel SAIC Company. ACC: DOC.20030611.0001.

Hawkinson, D. R. 1993. SNL Yucca Mountain Project Department 6302 Quality Assurance Evaluation, New England Research Inc. NER-E93-1. Albuquerque, NM: SNL.

ACC: NNA.19931215.0074.

Hawkinson, D.R. 1994. Quality Assurance Annual Evaluation Of New England Research, Inc QA Evaluation No. NER-E94-1 September, 1994. NER-E94-1. Albuquerque, NM: SNL. ACC: MOL.19950208.0064.

Martin, R.J., III; Price, R.H.; Boyd, P.J.; and Haupt, R.W. 1992. Anisotropy of the Topopah Spring Member Tuff. SAND91-0894. Albuquerque, New Mexico: Sandia National Laboratories. ACC: NNA.19920522.0041. 
Martin, R.J., III; Price, R.H.; Boyd, P.J.; and Noel, J.S. 1993. Unconfined Compression Experiments on Topopah Spring Member Tuff at $22^{\circ} \mathrm{C}$ and a Strain Rate of $10^{-9} \mathrm{~s}^{-1}$ : Data Report. SAND92-1810. Albuquerque, New Mexico: Sandia National Laboratories. ACC: NNA.19930728.0088.

Martin, R.J.; Price, R.H.; Boyd, P.J.; and Noel, J.S. 1995. Bulk and Mechanical Properties of the Paintbrush Tuff Recovered from Borehole USW NRG-7/7A: Data Report. SAND94-1996. Albuquerque, New Mexico: Sandia National Laboratories. ACC: MOL.19950316.0087.

McKeown, M. 1992. Soil and Rock Geotechnical Investigations Field and Laboratory Studies, North Ramp Surface Facility Exploratory Studies Facility, Yucca Mountain Project, Nevada. Technical Memorandum 3610-92-35. Denver, Colorado: U.S. Department of Interior, Bureau of Reclamation. ACC: NNA.19930607.0020.

Nimick, F.B.; Price, R.H.; Van Buskirk, R.G.; and Goodell, J.R. 1985. Uniaxial and Triaxial Compression Test Series on Topopah Spring Tuff from USW G-4, Yucca Mountain, Nevada. SAND84-1101. Albuquerque, New Mexico: Sandia National Laboratories. ACC: MOL.19980602.0332.

Nimick, F.B.; Van Buskirk, R.G.; and McFarland, A.F. 1987. Uniaxial and Triaxial Compression Test Series on the Topopah Spring Member from USW G-2, Yucca Mountain, Nevada. SAND85-0703. Albuquerque, New Mexico: Sandia National Laboratories. ACC: NNA.19891019.0289.

Olsson, W.A. and Jones, A.K. 1980. Rock Mechanics Properties of Volcanic Tuffs from the Nevada Test Site. SAND80-1453. Albuquerque, New Mexico: Sandia National Laboratories. ACC: NNA.19870406.0497.

Olsson, W.A. 1982. Effects of Elevated Temperature and Pore Pressure on the Mechanical Behavior of Bullfrog Tuff. SAND81-1664. Albuquerque, New Mexico: Sandia National Laboratories. ACC: NNA.19870406.0498.

PBT, Inc. 1993. Elastic Wave Velocity Measurements in Plug Core Samples from Borehole UE25 UZ \#16, Yucca Mountain, Nye County, Nevada. Golden, Colorado: PBT. Inc. ACC:

NNA.19931019.0042.

Price, R.H. 1983a. Analysis of the Rock Mechanics Properties of Volcanic Tuff Units from Yucca Mountain, Nevada Test Site. SAND82-1315. Albuquerque, New Mexico: Sandia National Laboratories. ACC: NNA.19870406.0181.

Price, R. H. 1983b. "Comparison of Division 1542 Mechanical Testing Procedures with ASTM Guidelines.” Memorandum from R. H. Price (SNL) to J. R. Tillerson (SNL), July 20, 1983. ACC: NNA.19870327.0051.

Price, R.H. 1986. Effects of Sample Size on the Mechanical Behavior of Topopah Spring Tuff. SAND85-0709. Albuquerque, New Mexico: Sandia National Laboratories. ACC: NNA.19891106.0125. 
Price, R.H.; Spence, S.J.; and Jones, A.K. 1984. Uniaxial Compression Test Series on Topopah Spring Tuff from USW GU-3, Yucca Mountain, Southern Nevada. SAND83-1646. Albuquerque, New Mexico: Sandia National Laboratories. ACC: NNA.19870406.0252.

Price, R.H.; Nimick, F.B.; Connolly, J.R.; Keil, K.; Schwartz, B.M.; and Spence, S.J. 1985. Preliminary Characterization of the Petrologic, Bulk, and Mechanical Properties of a Lithophysal Zone Within the Topopah Spring Member of the Paintbrush Tuff. SAND84-0860. Albuquerque, New Mexico: Sandia National Laboratories. ACC: NNA.19870406.0156.

Price, R.H.; Nimick, F.B.; Connolly, J.R.; Keil, K.; Schwartz, B.M.; and Spence, S.J. 1985. Preliminary Characterization of the Petrologic, Bulk, and Mechanical Properties of a Lithophysal Zone Within the Topopah Spring Member of the Paintbrush Tuff. SAND84-0860. Albuquerque, New Mexico: Sandia National Laboratories. ACC: NNA.19870406.0156.

Senseny, P. and Mellegard, K. 1987. "Constant Strain-Rate Testing of Topopah Spring Tuff at $150^{\circ}$ C." Technical letter memorandum from P. Senseny (RE/SPEC) and K. Mellegard (RE/SPEC) to F. Nimick (SNL), May 21, 1987, RSI/TLM-144. ACC: NNA.19890825.0178.

SNL (Sandia National Laboratories) 1997. Unconfined Compression Tests on Specimens from the Drift Scale Test Area of the Exploratory Studies Facility at Yucca Mountain, Nevada. Albuquerque, New Mexico: Sandia National Laboratories. ACC: MOL.19971120.0014.

SNL (Sandia National Laboratories) 1999a. Checklist Procurements, Supplier: New England Research INC., Procurement Date: 09/01/1994. Procurement No. AI-3890. Albuquerque, New Mexico: Sandia National Laboratories. ACC: MOL.20020923.0029.

SNL (Sandia National Laboratories) 1999b. Checklist Procurements, Supplier: New England Research INC., Procurement Date: 08/29/1989. Procurement No. 05-6677B. Albuquerque, New Mexico: Sandia National Laboratories. ACC: MOL.20020923.0028.

Van Buskirk, R.G., Muller, C.S., Cooley, C.H., and Ennis, D.O. 1984. Triaxial Compression Testing of Busted Butte (NTS) Tuff 10 AE. TR 84-45. 115 p. Salt Lake City, UT: Terra Tek Research. ACC: MOL.19970428.0083.

\subsection{CODES, STANDARDS, REGULATIONS, AND PROCEDURES}

10 CFR 60. Energy: Disposal of High-Level Radioactive Wastes in Geologic Repositories.

10 CFR 63. Energy: Disposal of High-Level Radioactive Wastes in a Geologic Repository at Yucca Mountain, Nevada.

AP-3.11Q, Rev. 3, ICN 4. Technical Reports. Washington, D.C.: U.S. Department of Energy, Office of Civilian Radioactive Waste Management. ACC: DOC.20030331.0002.

AP-3.15Q, Rev 4, ICN 1. Managing Technical Product Inputs. Washington, D.C. U.S. Department of Energy, Office of Civilian Radioactive Waste Management. ACC: DOC.20030512.0006. 
AP-SIII.2Q, Rev. 1, ICN 1. Qualification of Unqualified Data. Washington, D.C.: U.S. Department of Energy, Office of Civilian Radioactive Waste Management. ACC: DOC.20030422.0008.

AP-SIII.4Q, Rev. 0, ICN 5. Development, Review, Online Placement, and Maintenance of Individual Reference Information Base Data Items. Washington, D.C.: U.S. Department of Energy, Office of Civilian Radioactive Waste Management. ACC: DOC.20030127.0002.

ANSI/ASTM D 2938-79. 1979. Standard Test Method for Unconfined Compressive Strength of Intact Rock Core Specimens. Philadelphia, Pennsylvania: American Society for Testing and Materials. TIC: 217288.

ASTM D 2664-80. 1980. Standard Test Method for Triaxial Compressive Strength of Undrained Rock Core Specimens Without Pore Pressure Measurements. Philadelphia, Pennsylvania: American Society for Testing and Materials. TIC: 217286.

ASTM D 2664-86. 1992. Standard Test Method for Triaxial Compressive Strength of Undrained Rock Core Specimens Without Pore Pressure Measurements. Philadelphia, Pennsylvania: American Society for Testing and Materials. TIC: 245311.

ASTM D 2845-83. 1983. Laboratory Determination of Pulse Velocities and Ultrasonic Elastic Constants of Rock. Philadelphia, Pennsylvania. American Society for Testing and Materials. TIC: 217296.

ASTM D 2938-86. 1986. Standard Test Method for Unconfined Compressive Strength of Intact Rock Core Specimens. Philadelphia, Pennsylvania: American Society for Testing and Materials. TIC: 239669.

ASTM D 3148-86. 1986. Standard Test Method for Elastic Moduli of Intact Rock Core Specimens in Uniaxial Compression. Philadelphia, Pennsylvania: American Society for Testing and Materials. TIC: 253352.

ASTM D 4543-85 (Reapproved 1991). 1991. Standard Practice for Preparing Rock Core Specimens and Determining Dimensional and Shape Tolerances. Philadelphia, Pennsylvania: American Society for Testing and Materials. TIC: 250302.

DOE (U.S. Department of Energy) 2003. Quality Assurance Requirements and Description. DOE/RW-0333P, Rev. 13. Washington, D.C.: U.S. Department of Energy, Office of Civilian Radioactive Waste Management. ACC: DOC.20030422.0003.

\subsection{SOURCE DATA, LISTED BY DATA TRACKING NUMBER}

GS900983115212.001. Report on Televiewer Log and Stress Measurements in Core Hole USW G-1, Nevada Test Site, December 13-22, 1981. Submittal Date: 09/17/1990.

GS900983115212.002. Report on Televiewer Log and Stress Measurements in Core Hole USW G-2, Nevada Test Site, October-November 1982. Submittal date: 09/17/1990. 
GS900983115212.003. Report on Televiewer Log and Stress Measurements in Holes USW G-3 and UE-25P1 (UW-25P \#1), Yucca Mountain, Nye County, Nevada. Submittal date: 09/17/1990.

GS920983114220.001. Log of Test Pit or Auger Hole, Physical Properties Summary, Gradation Test, and Summary of Physical Properties Test Results for Hole Numbers NRSF-TP-11, TP-19, TP-21, TP-25, TP-28, TP-29, and TP-30. Submittal date: 09/03/1992.

GS920983114220.002. Drill Hole UE-25 NRG-1 Rock Core Tests. Submittal date: 10/14/1992.

GS921283114220.003. Relative Density Determination, Lab Tests of Physical Properties, North Ramp. Submittal date: 12/03/1992.

GS921283114220.004. Summary Access Road Test Pit Data, Logs of Visual Observations of Site and Test Pit. Submittal date: 12/03/1992.

GS921283114220.005. Physical Properties and Dimensional Tolerance Conformance of Rock Core Test Specimens. Submittal date: 12/03/1992.

GS921283114220.006. Pulse Velocities and Ultrasonic Elastic Constants of Intact Rock Core Test Specimens. Submittal date: 12/03/1992.

GS921283114220.008. Uniaxial Compression and Elastic Properties of Intact Rock Core Specimens from UE-25 NRG\#1. Submittal date: 12/03/1992.

GS921283114220.009. Triaxial Compression and Elastic Properties of Intact Rock Core Test Specimens From UE-25 NRG\#1. Submittal date: 12/03/1992.

GS921283114220.014. Soil and Rock Geotechnical Investigations, Field and Laboratory Studies, North Ramp Surface Facility, Exploration Studies Facility, Yucca Mountain Project, Nevada. Submittal date: 12/04/1992.

GS931008314211.037. Graphical Lithologic Log of Borehole NRG-3 (UE-25 NRG\#3), Version 1.0. Submittal date: $10 / 07 / 1993$.

GS931008314211.038. Graphical Lithologic Log of Borehole NRG-2A (UE-25 NRG\#2A), Version 1.0. Submittal date: 10/07/1993.

GS931008314211.039. Graphical Lithologic Log of Borehole NRG-2 (UE-25 NRG\#2), Yucca Mountain, Nevada. Submittal date: 10/07/1993.

GS931008314211.045. Graphical Lithologic Log of Borehole USW NRG-6. Submittal date: 10/07/1993.

GS931108314211.041. Graphical Lithologic Log of Borehole NRG-2B (UE-25 NRG\#2B), Yucca Mountain, Nevada. Submittal date: 10/07/1993.

GS931208314211.046. Graphical Lithologic Log of Borehole UE-25 NRG\#1. Submittal date: $11 / 22 / 1993$. 
GS931208314211.049. Revised Stratigraphic Nomenclature and Macroscopic Identification of Lithostratigraphic Units of the Paintbrush Group Exposed at Yucca Mountain, Nevada.

Submittal date: 10/12/1993.

GS940408314211.020. Graphical Lithologic Log of Borehole USW NRG-7/7A. Submittal date: 04/04/1994.

GS940408312232.010. Elastic Wave Velocity Measurements in Plug Core Samples from Borehole UE-25 UZ \#16, Yucca Mountain, Nye County, Nevada. 02/10/1994.

GS940908314211.045. Graphical Lithologic Log of the Paintbrush Group for Borehole USW SD-12. Submittal date: 09/12/1994.

LL000209404243.036. Geomechanical Characterization of Large Block Core Specimens. Submittal date: 02/24/2000.

LL000314151021.122. Clad Degradation- Wet Unzipping. Submittal date: 03/13/2000.

LL010700823123.014. Geomechanical Characterization of Large Block Core Specimens.

Submittal date: 07/11/2001.

LL9503RIB0031A.000. RIB Item \# 31A/REV0: Waste Package Properties and Environment: Waste Package Mechanical Properties (Alloy 825 and Carbon Steel). Submittal date: 03/15/1995.

LL950712904243.000. Effects of Radiation on Geomechanical Properties of Topopah Spring Tuff. Submittal date: 08/07/1995.

LL960201104243.006. Results from the Uniaxial Tests on Samples of Topopah Spring Tuff. Submittal date: 03/18/1996.

LL960401604243.007. Procedure Taken to Test Irradiated and Non-Irradiated Core Samples from Fran Ridge. Submittal date: 04/01/1996.

LL960401704243.008. Effect of Radiation on the Mechanical Properties of Topopah Spring Tuff. Submittal date: 04/01/1996.

LL960807504241.012. Volume II: Near-Field and Altered-Zone Environment Report. Submittal date: $08 / 27 / 1996$.

LL960905005911.010. Engineered Materials Characterization Report for the Yucca Mountain Site Characterization Project. Submittal date: 09/20/1996.

LL970203704243.010. Effect of Radiation on Topopah Spring Tuff Mechanical Properties. Submittal date: 02/14/1997.

LL9708RIB0031A.001. Engineered Materials Characteristics. Submittal date: 09/02/1997. 
LL980200604241.013. Near-Field and Altered-Zone Environment Report Volume I: Technical Bases for EBS Design, Revision 1. Submittal date: 02/03/1998.

LL980208104243.019. Mechanical Properties of Topopah Spring Host Rock, and Fractures in the Host Rock. Submittal date: 02/23/1998.

LL980802204243.020. Results of a Coupled Fracture-Flow Test at the 0.5-M Scale. Submittal date: $08 / 13 / 1998$.

LL981208504243.031. Effect of Radiation on Topopah Spring Tuff Mechanical Properties. Submittal date: 12/08/1998.

LL981212005924.062. Degradation Mode Survey Candidate Titanium-Base Alloys for Yucca Mountain Project Waste Package Materials. Submittal date: 12/22/1998.

LL990202204241.036. Geomechanics. Submittal date: 02/08/1999.

LL990205304243.032. Effect of Radiation on Strength of Topopah Springs Tuff. Submittal date: 02/08/1999.

MO0003RIB00071.000. Physical and Chemical Characteristics of Alloy 22. Submittal date: 03/13/2000.

MO0003RIB00072.000. Physical and Chemical Characteristics of Steel, A 516. Submittal date: 03/13/2000.

MO0003RIB00073.000. Physical and Chemical Characteristics of TI Grades 7 and 16. Submittal date: $03 / 13 / 2000$.

MO0003RIB00076.000. Physical and Chemical Characteristics of Type 316N Grade. Submittal date: $03 / 14 / 2000$.

MO0004QGFMPICK.000. Lithostratigraphic Contacts from MO9811MWDGFM03.000 to be Qualified Under the Data Qualification Plan, TDP-NBS-GS-000001. Submittal date: 04/04/2000.

MO0004SEPDFFVV.008. Free-Field Values of Shear-Wave Velocity, Compression-Wave Velocity, Poisson's Ratio, and Moist Density at Borehole UE-25 RF\#13. Submittal date: 04/07/2000.

MO0006SPASTR01.003. Area of Stress Corrosion Crack for the EBS Transport Abstraction. Submittal date: 06/09/2000.

MO0008RIB00082.000. Rock Dynamic Properties. Submittal date: 08/02/2000

MO0104RIB00042.001. Soil Geomechanical Properties. Submittal date: 04/09/2001.

MO0109RIB00049.001. Waste Package Material Properties: Neutron Absorbing Materials.

Submittal date: 09/17/2001. 
MO0111SEPBSWHB.000. Borehole Suspension Data for Waste Handling Building Site Characterization Area. Submittal date: 11/06/2001.

MO0112BSUSPWHB.000. Borehole Suspension Data for UE-25 RF \#13 at the Waste Handling Building Site Characterization Area. Submittal date: 12/03/2001. Submit to RPC.

MO0204EBSPYMPG.017. Physical and Mechanical Properties of Grout. Submittal date: $04 / 23 / 2002$.

MO0204RIB00124.000. Rock Dynamic Poisson's Ratio. Submittal date: 04/03/2002.

MO0204RIB00125.000. Rock Dynamic Young's Modulus. Submittal date: 04/04/2002.

MO0204RIB00126.000. Intact Rock Poisson's Ratio. Submittal date: 04/03/2002.

MO0204RIB00127.000. Intact Rock Young's Modulus. Submittal date: 04/03/2002.

MO0204RIB00129.000. In Situ Rock Young's Modulus. Submittal date: 04/03/2002.

MO0204SEPBSWHB.001. Borehole Suspension Data for Waste Handling Building Site Characterization Area. Submittal date: 04/10/2002.

MO0204SEPFDSSS.000. Profiles of Average Shear-Wave Velocity, Compression-Wave Velocity and Poisson's Ratio from Accumulated Travel Times from Suspension Seismic Surveys at Boreholes UE-25 RF\#14 to \#26 and RF\#28 and RF\#29. Submittal date: 04/22/2002.

MO0204SUSPSEIS.001. Statistics for Shear-Wave Velocity, Compression-Wave Velocity, and Poisson's Ratio by Lithostratigraphic Unit from Suspension Seismic Measurements. Submittal date: $04 / 23 / 2002$.

MO02045FTDSUSP.001. Statistics for Shear-Wave Velocity, Compression-Wave Velocity, and Poisson's Ratio by 1.5 Meter Depth Intervals from Suspension Seismic Measurements. Submittal date: $04 / 23 / 2002$.

MO0205SEPPRDSV.000. Profiles of Poisson's Ratio from Downhole Seismic Velocity Profiles at Boreholes UE-25 RF\#13 to \#26 and RF\#28 and RF\#29. Submittal date: 05/28/2002.

MO9008RIB00012.003. RIB Item\#12/Rev3: Geologic Characteristics: Static Rock Mechanical Properties. Submittal date: 08/06/1990.

MO9212RIB00005.003. RIB Item \#5/REV3: Geologic Characteristics: Dynamic Soil Mechanical Properties. Submittal date: 12/14/1992.

MO9808RIB00041.000. Reference Information Base Data Item: Rock Geomechanical Properties. Submittal date: 08/05/1998.

MO9808RIB00042.000. Reference Information Base Data Item: - Geologic Characteristics: Soil Geomechanical Properties. Submittal date: 08/05/1998. 
MO9906RIB00048.000. Waste Package Material Properties: Waste Form Materials. Submittal date: 6/9/1999.

MO9906RIB00049.000. Waste Package Material Properties: Neutron Absorbing Materials. Submittal date: 06/16/1999.

MO9906RIB00050.000. Waste Package Material Properties: Ceramic Coating Materials. Submittal date: 06/16/1999.

MO9906RIB00052.000. Waste Package Material Properties: Corrosion Resistant Materials. Submittal date: 06/17/1999.

MO9906RIB00053.000. Waste Package Materials Properties: Corrosion Allowance and Basket Materials. Submittal date: 06/17/1999.

MO9906RIB00054.000. Waste Package Material Properties: Structural Materials. Submittal date: $06 / 17 / 1999$.

MO9911SEPGRP34.000. Geotechnical Rock Properties. Submittal date: 11/10/1999.

MO9912SPABAS00.001. Basic Properties Of Several Metals from "Standard Handbook for Mechanical Engineers, 7th Edition". Submittal date: 12/23/1999.

SN0011F3912298.023. Plate-Loading Rock Mass Modulus Data (with Results from 10/16/2000 through 10/17/2000). Submittal date: 11/30/2000.

SN0108SD821723.001. Uniaxial and Triaxial Compression Test Data on Samples from USW G-1 (VA Supporting Data). Submittal date: 08/09/2001.

SNF35110695001.002. Pre-Experiment Thermal-Hydrological-Mechanical Analyses for the ESF Single Heater Test - Phase 2. Submittal date: 01/09/1997.

SNF35110695002.001. Pre-Experiment Thermal-Hydrological-Mechanical Analyses for the ESF Heated Drift Test. Submittal date: 06/10/1997.

SNF39012298001.002. Plate-Loading Rock Mass Modulus Data. Submittal date: 02/09/1999.

SNL01B05059301.001. Thermal Expansion Data for Drillhole NRG-6, Samples from Depth 28.8 to 416.0 Feet, Ambient to 100 Deg. C. Submittal date: 07/30/1993.

SNL01B05059301.002. Thermal Expansion Data from USW NRG-6 Drillhole from Depth of $28.8 \mathrm{ft}$. to $416.0 \mathrm{ft}$. Submittal date: 11/23/1993.

SNL02000000011.000. Matrix Compressive Tests of the Topopah Spring Member in USW GU-3. Submittal date: 09/23/1992.

SNL02000000012.000. Uniaxial and Triaxial Compression Test Series on Topopah Spring Tuff. Submittal date: 01/04/1985. 
SNL02021391002.001. Direct Shear Test with Different Boundary Conditions. Submittal date: 11/04/1992.

SNL02030180001.001. Matrix Compressive Tests to Characterize Tuffs from UE-25A\#1 and the Laser Drift in G-Tunnel. Submittal date: 08/20/1985.

SNL02030193001.001. Mechanical Properties Data for Drillhole USW NRG-6 Samples from Depth $22.2 \mathrm{ft}$. to $328.7 \mathrm{ft}$. Submittal date: 05/17/1993.

SNL02030193001.002. Mechanical Properties Data for Drillhole USW NRG-6 Samples from Depth $22.2 \mathrm{ft}$. to $427.0 \mathrm{ft}$. Submittal date: 06/25/1993.

SNL02030193001.003. Mechanical Properties Data for Drillhole UE-25 NRG-2 Samples from Depth $150.5 \mathrm{ft}$. to $200.0 \mathrm{ft}$. Submittal date: 07/07/1993.

SNL02030193001.004. Mechanical Properties Data for Drillhole USW NRG-6 Samples from Depth $462.3 \mathrm{ft}$. to $1085.0 \mathrm{ft}$. Submittal date: 08/05/1993.

SNL02030193001.005. Mechanical Properties Data for Drillhole UE-25 NRG\#3 Samples from Depth $15.4 \mathrm{ft}$. to $297.1 \mathrm{ft}$. Submittal date: 09/23/1993.

SNL02030193001.006. Mechanical Properties Data for Drill Hole UE-25 NRG\#2A Samples from Depth $90.0 \mathrm{ft}$. to $254.5 \mathrm{ft}$. Submittal date: 10/13/1993.

SNL02030193001.007. Mechanical Properties Data for Drill Hole UE-25 NRG\#3 Samples from Depth $263.3 \mathrm{ft}$. to $265.7 \mathrm{ft}$. Submittal date: 10/20/1993.

SNL02030193001.008. Mechanical Properties Data for Drill Hole USW NRG-6 Sample $416.0 \mathrm{ft}$. Submittal date: 10/20/1993.

SNL02030193001.012. Mechanical Properties Data for Drillhole UE25 NRG-5 Samples from Depth $847.2 \mathrm{ft}$. to $896.5 \mathrm{ft}$. Submittal date: 12/02/1993.

SNL02030193001.013. Mechanical Properties Data for Drillhole UE25 NRG-2B Samples from Depth $2.7 \mathrm{ft}$. to $87.6 \mathrm{ft}$. Submittal date: 12/02/1993.

SNL02030193001.014. Mechanical Properties Data for Drillhole UE25 NRG-4 Samples from Depth $378.1 \mathrm{ft}$. to $695.8 \mathrm{ft}$. Submittal date: 01/31/1994.

SNL02030193001.015. Mechanical Properties Data for Drillhole UE25 NRG-4 Samples from Depth $527.0 \mathrm{ft}$. Submittal date: 02/16/1994.

SNL02030193001.016. Mechanical Properties Data for Drillhole USW NRG-7/7A Samples from Depth $18.0 \mathrm{ft}$. to $472.9 \mathrm{ft}$. Submittal date: 03/16/1994.

SNL02030193001.018. Mechanical Properties Data for Drillhole USW NRG-7/7A Samples from Depth $344.4 \mathrm{ft}$. Submittal date: 04/11/1994. 
SNL02030193001.019. Mechanical Properties Data for Drillhole USW NRG-7/7A Samples from Depth $507.4 \mathrm{ft}$. to $881.0 \mathrm{ft}$. Submittal date: 06/29/1994.

SNL02030193001.020. Mechanical Properties Data for Drillhole USW NRG-7/7A Samples from Depth $554.7 \mathrm{ft}$. to $1450.1 \mathrm{ft}$. Submittal date: 07/25/1994.

SNL02030193001.021. Mechanical Properties Data (Ultrasonic Velocities, Static Elastic Properties, Triaxial Strength, Dry Bulk Density \& Porosity) for Drillhole USW NRG-7/7A Samples from Depth $345.0 \mathrm{ft}$. to $1408.6 \mathrm{ft}$. Submittal date: 02/16/1995.

SNL02030193001.022. Mechanical Properties Data for Drill Hole USW NRG-6 Samples from Depth $5.7 \mathrm{ft}$. to $1092.3 \mathrm{ft}$. Submittal date: 02/27/1995.

SNL02030193001.023. Mechanical Properties Data (Ultrasonic Velocities, Static Elastic Properties, Unconfined Strength, Triaxial Strength, Dry Bulk Density and Porosity) for Drillhole USW SD-12 Samples from Depth $16.1 \mathrm{ft}$. to $1300.3 \mathrm{ft}$. Submittal date: 08/02/1995.

SNL02030193001.024. Elevated Temperature Confined Compression Tests (Ultrasonic Velocities, Static Elastic Properties, Unconfined Strength, Triaxial Strength, Dry Bulk Density and Porosity) for Drillhole USW SD-9 Samples from Depth $52.6 \mathrm{ft}$. to $2222.9 \mathrm{ft}$. Submittal date: 09/05/1995.

SNL02030193001.025. Mechanical Properties Data (Ultrasonic Velocities, Elastic Moduli, and Fracture Strength) for Borehole USW SD-9. Submittal date: 09/15/95.

SNL02030193001.026. Mechanical Properties Data (Ultrasonic Velocities, Elastic Moduli and Fracture Strength) for Borehole USW SD-9. Submittal date: 02/22/1996.

SNL02030193001.028. Confined Compression Experiments at 150 Degrees C on TSW2 from Borehole USW SD-9. Submittal date: 09/05/1996.

SNL02033084001.001. Matrix Compressive Tests of the Topopah Spring Member in USW G-2. Submittal date: 01/01/1988.

SNL02033084002.001. Parameter Effects on Matrix Compressive Properties of the Topopah Spring Member at Busted Butte. Submittal date: 08/28/1987.

SNL02040184001.001. Effects of Lithophysae on the Matrix Compressive Properties. Submittal date: $01 / 07 / 1985$.

SNL02040687003.001. Mechanical Property Data to Analyze the Response of Samples of Unit TSW2 to High Temperature and/or Low Strain Rates. Submittal date: 09/30/1992.

SNL02040687004.001. Creep in Topopah Spring Member Welded Tuff. Submittal date: 07/07/1998.

SNL02062685001.001. Determinations of the Effect of Sample Size on the Mechanical Properties of the Welded Topopah Spring Member, Busted Butte. Submittal date: 09/09/1986. 
SNL02072983001.001. Laboratory Comparison of Mechanical Compressive Data from Matrix Compressive Tests Using Busted Butte Outcrop Samples. Submittal date: 01/03/1985.

SNL02072983002.001. Laboratory Comparison of Mechanical Compressive Data from Matrix Compressive Tests Using Busted Butte Outcrop Samples. Submittal date: 01/03/1985.

SNL02072983003.001. Laboratory Comparison of Mechanical Compressive Data from Matrix Compressive Tests Using the Busted Butte Outcrop Samples. Submittal date: 01/03/1985.

SNL02100181001.001. Laboratory Comparison of Matrix Compressive Tests Using the Calico Hills Member in USW G-1. Submittal date: 05/01/1982.

SNL02100196001.001. Unconfined Compression Tests on Specimens from the Drift Scale Test Area of the Exploratory Studies Facility at Yucca Mountain, Nevada. Submittal date: 05/14/1997.

SNL02120584001.001. Matrix Compressive Tests to Determine Parameter Effects. Submittal date: $06 / 01 / 1986$.

SNL04021384001.001. Characterization of Samples in Support of Mechanical Testing on Densely Welded Samples of the Topopah Spring Member from Busted Butte. Submittal date: 02/25/1987.

SNL04041990001.001. USW G-1 Probe Data Topopah Spring Member. Submittal date: 05/01/1991.

SNL22080196001.002. Unconfined Compression Tests on Specimens from the Single Heater Test Area in the Thermal Testing Facility at Yucca Mountain, Nevada. Submittal date: 08/22/1996.

SNL22080196001.003. Posttest Laboratory Thermal and Mechanical Characterization for Single Heater Test (SHT) Block. Submittal date: 08/26/1998.

SNL23030598001.001. Unconfined Compression Tests on Cast-in-Place Concrete Specimens from the Drift Scale Test in the ESP (Exploratory Studies Facility) at Yucca Mountain, Nevada. Submittal date: 03/10/1998.

SNL23030598001.002. Interim Report on Creep Testing of Cast-In-Place Concrete. Submittal date: $07 / 09 / 1998$.

SNL23030598001.003. Creep Testing of Cast-in-Place Concrete. Submittal date: 10/09/1998.

SNL23100198001.001. Laboratory Testing of Concrete Properties at Elevated Temperatures (Including Aggregate Characterization). Submittal date: 12/22/1998.

SNSAND80145300.000. Rock Mechanics Properties of Volcanic Tuffs from the Nevada Test Site. Submittal date: 01/04/1985. 
SNSAND81166400.000. Effects of Elevated Temperature and Pore Pressure on the Mechanical Behavior of Bullfrog Tuff. Submittal date: 11/30/1998.

SNSAND82048100.000. Uniaxial Compression Test Series on Bullfrog Tuff. Submittal date: $11 / 30 / 1998$.

SNSAND82105500.000. Uniaxial Compression Test Series on Tram Tuff. Submittal date: 11/30/1998.

SNSAND82131400.000. Uniaxial and Triaxial Compression Test Series on Calico Hills Tuff. Submittal date: 04/24/1992.

SNSAND82131500.000. Analysis of Rock Mechanics Properties of Volcanic Tuff Units from Yucca Mountain, Nevada Test Site. Submittal date: 02/10/1997.

SNSAND82172300.000. Load Cell LVDT's and Disk Gage Calibration Data; Aluminum Sample Calibration Data I.D. MN Load Frame; Load Cell, LVDT's and Disk Gage Calibration Data 1.8 MN Frame; and Aluminum Sample Calibration Data - Compression Tests. Submittal date: 04/23/1992.

SNSAND83164600.000. Experimental Data of Fully Saturated and Wet Samples; Static Mechanical Properties of GU-3 760.9 Samples; Ultrasonic Velocity Data; and Dynamic Elastic Model of GU-3 760.9 Samples Compression Test. Submittal date: 04/24/1992.

SNSAND84086000.000. Petrological, Mineralogical, Mechanical and Bulk Properties of Lithophysal Tuff. Submittal date: 04/24/1992.

SNSAND84110100.000. Uniaxial and Triaxial Compression Test Series on Topopah Spring Tuff from USW G-4, Yucca Mountain, Nevada. Submittal date: 02/01/1986.

SNSAND85070300.000. Uniaxial and Triaxial Compression Test Series on the Topopah Spring Member from USW G-2, Yucca Mountain, Nevada. Submittal date: 09/24/1987.

SNSAND85070900.000. Effects of Sample Size on the Mechanical Behavior of the Topopah Spring Tuff. Submittal date: 12/16/1998.

SNSAND85076200.000. Bulk, Thermal, and Mechanical Properties of the Topopah Spring Member of the Paintbrush Tuff, Yucca Mountain, Nevada. Submittal date: 10/17/1987.

SNSAND86101500.000. Summary of Geomechanical Measurements taken in and around the GTunnel Underground Facility, NTS. Submittal date: 07/29/1984.

SNSAND86113100.000. Petrologic and Mechanical Properties of Outcrop Samples of the Welded, Devitrified Topopah Spring Member of the Paintbrush Tuff. Submittal date: 06/11/1987. 
SNSAND86713000.000. Laboratory Determination of the Mechanical, Ultrasonic and Hydrologic Properties of Welded Tuff from the Grouse Canyon Heated Block Site. Submittal date: $08 / 01 / 1987$.

SNSAND91089400.000. Anisotropy of the Topopah Spring Member Tuff. Submittal date: 01/08/1999.

SNSAND92045000.000. Rock Mass Mechanical Property Estimations for the Yucca Mountain Site Characterization Project. Submittal date: 01/10/1994.

SNSAND92084700.000. The Effect of Frequency on Young's Modulus and Seismic Wave Attenuation. Submittal date: 08/10/1994.

UN0110MWD027MK.001. Lythophysal Porosity Stress/Strain Model. Submittal date: $10 / 15 / 2001$. 

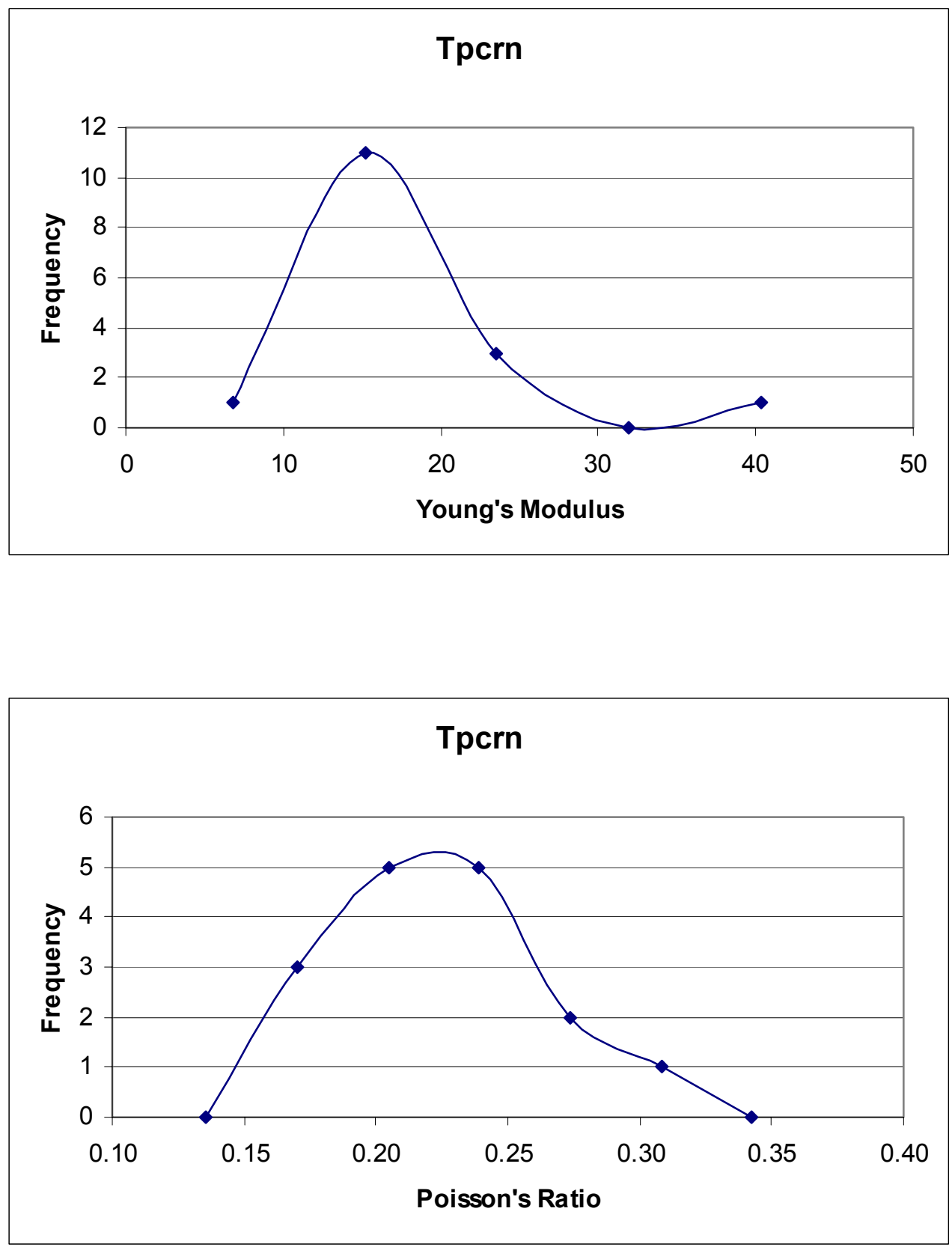

Figure 1. Static Young's Modulus (GPa) and Poisson's Ratio Frequency Distribution for Tpcrn 

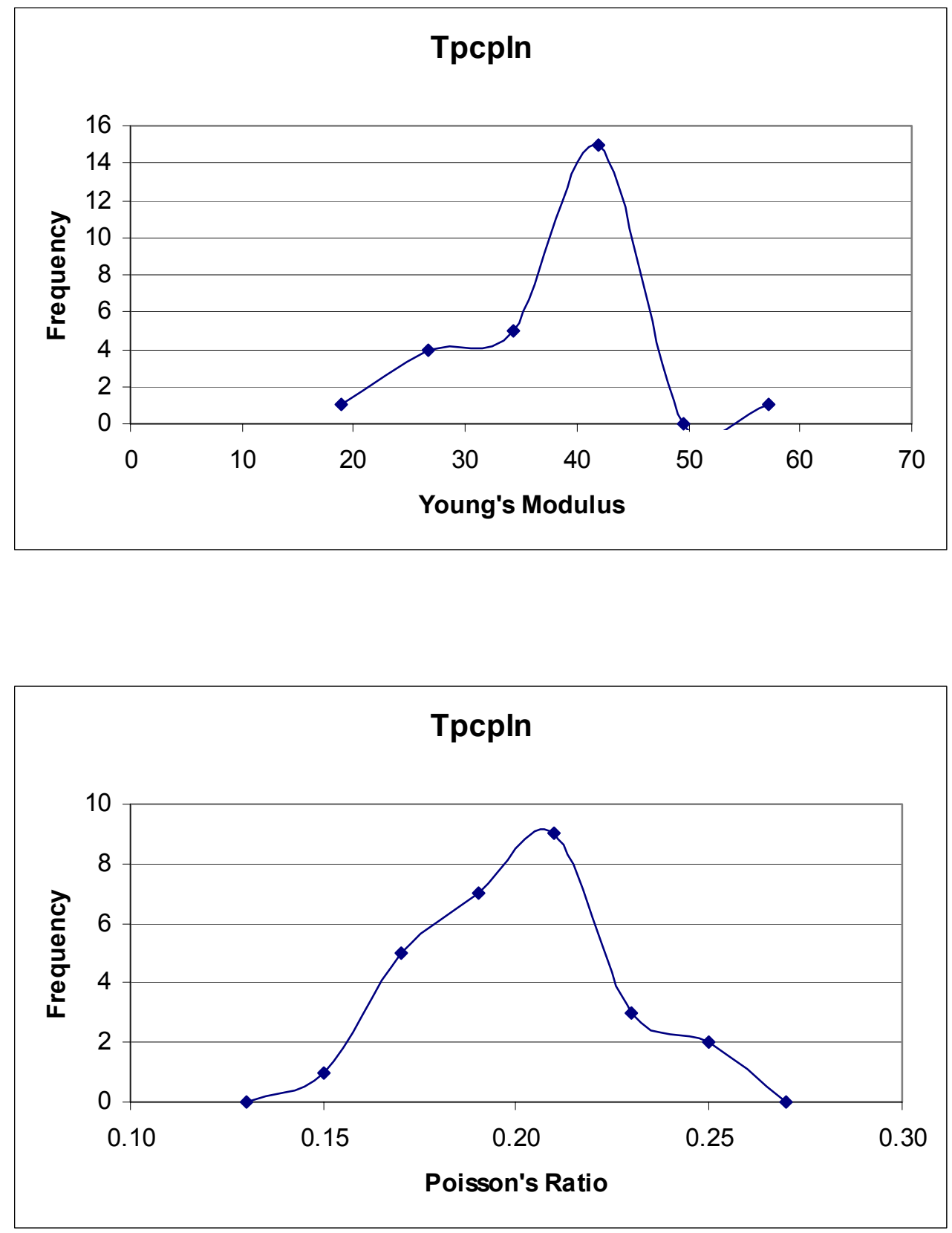

Figure 2. Static Young's Modulus (GPa) and Poisson's Ratio Frequency Distribution for Tpcpln 

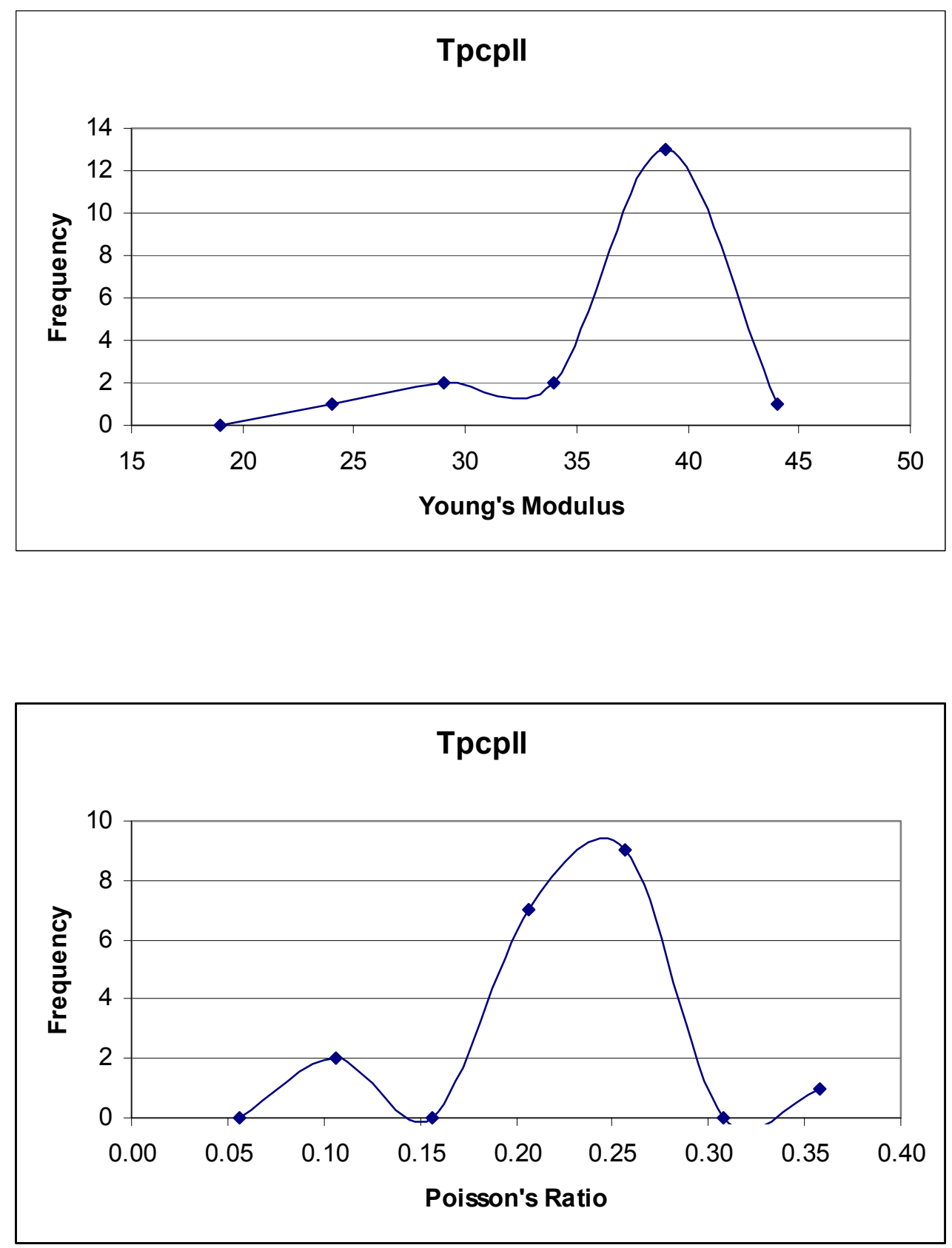

Figure 3. Static Young's Modulus (GPa) and Poisson's Ratio Frequency Distribution for Tpcpll 

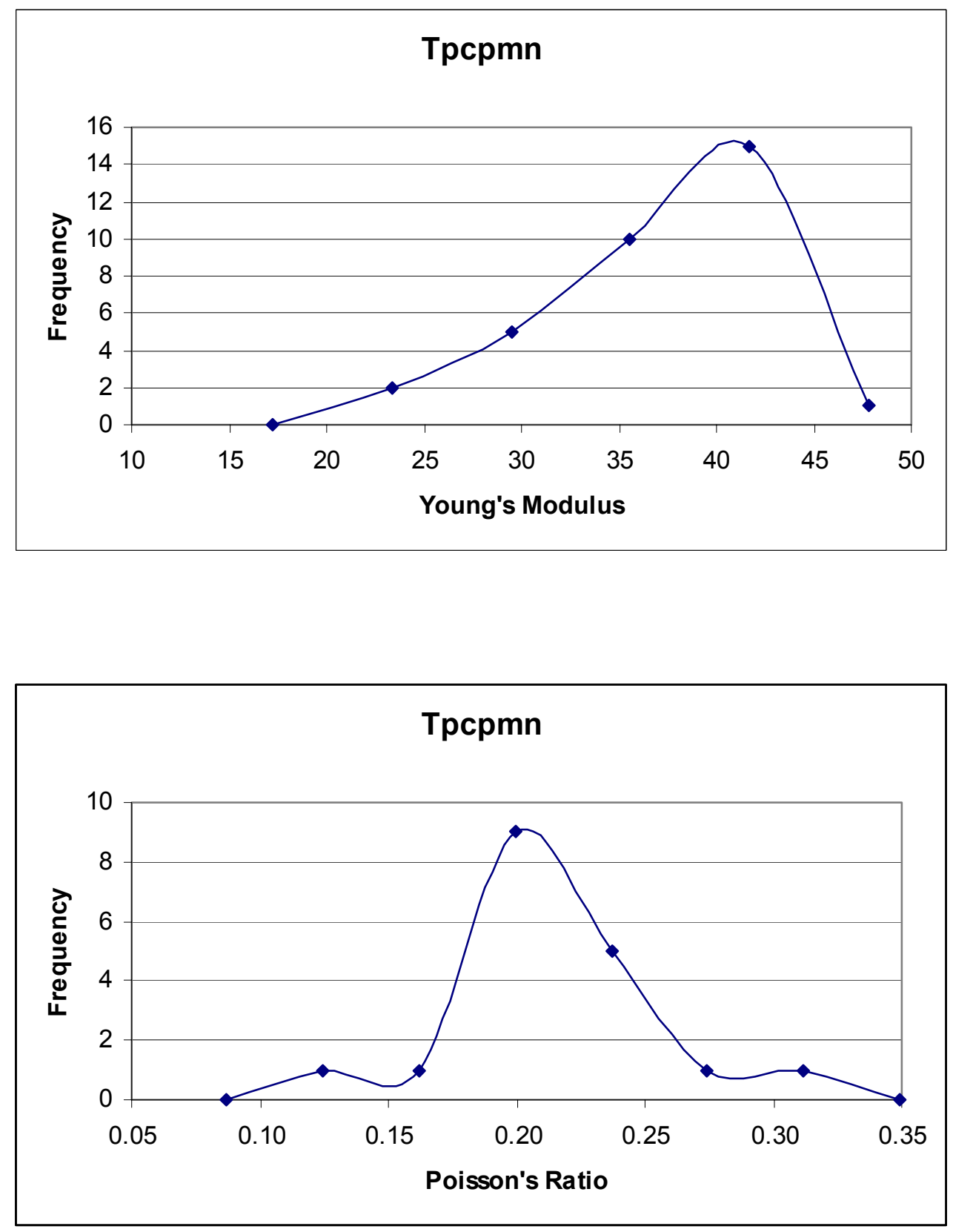

Figure 4. Static Young's Modulus (GPa) and Poisson's Ratio Frequency Distribution for Tpcpmn 

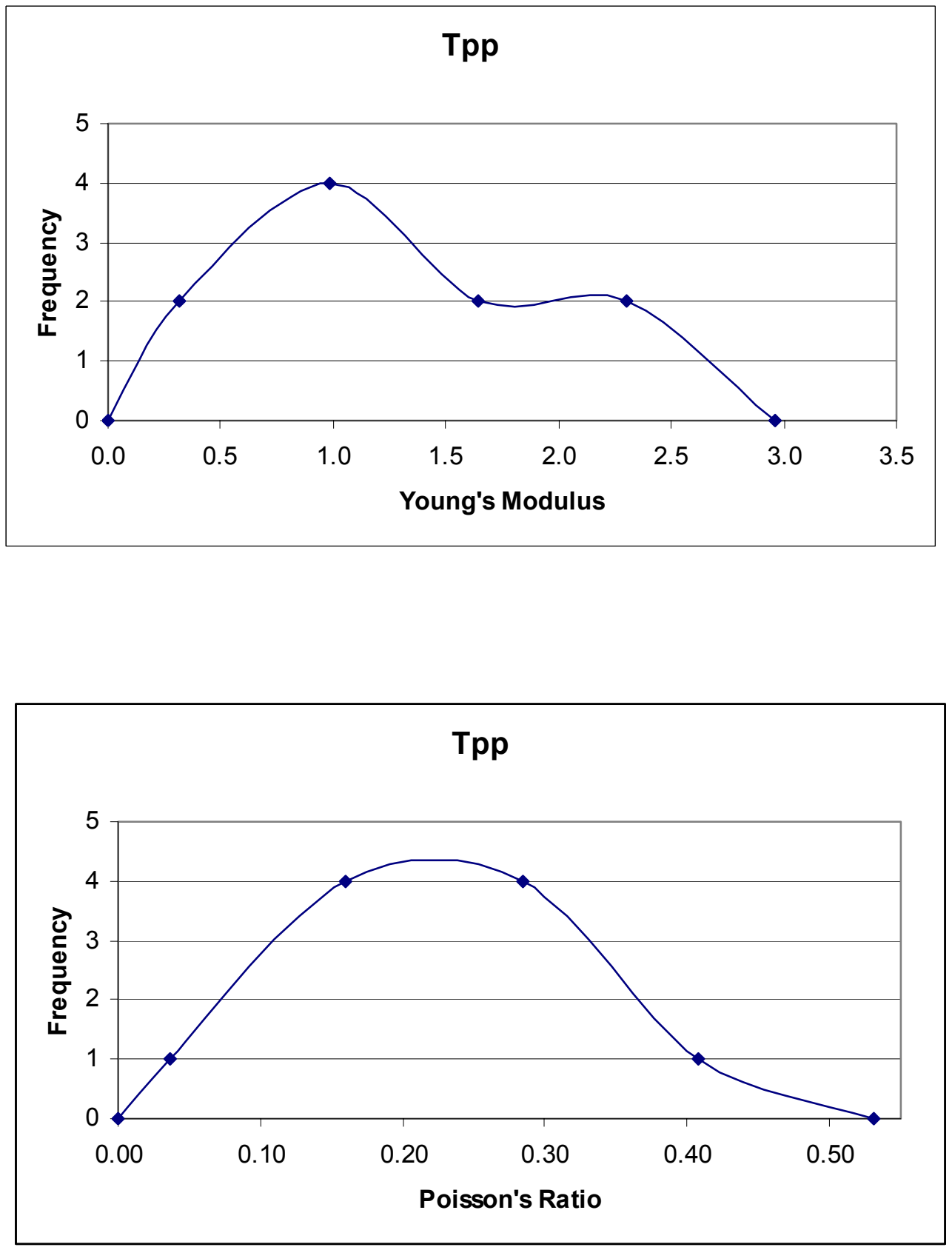

Figure 5. Static Young's Modulus (GPa) and Poisson's Ratio Frequency Distribution for Tpp 

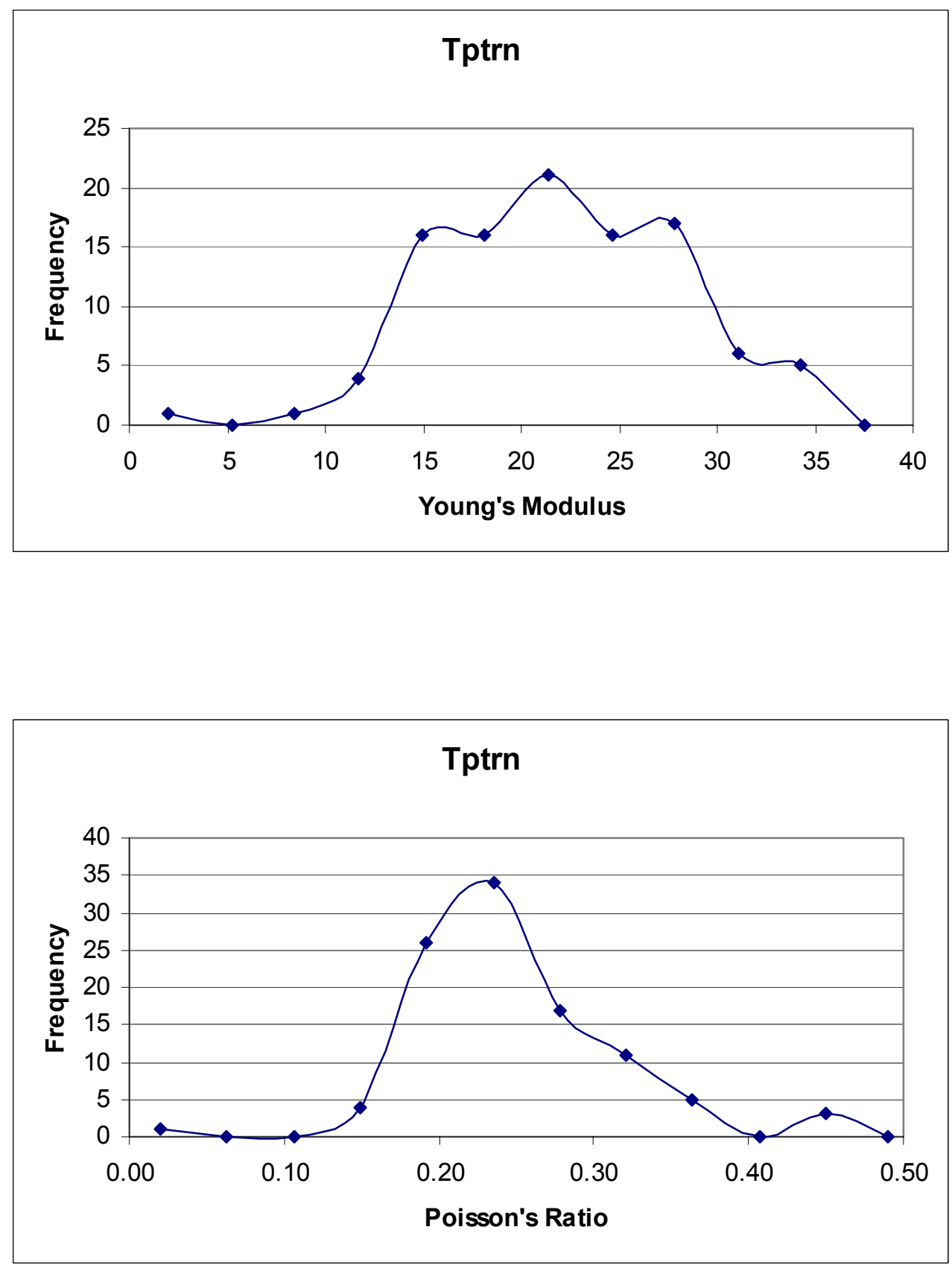

Figure 6. Static Young's Modulus (GPa) and Poisson's Ratio Frequency Distribution for Tptrn 

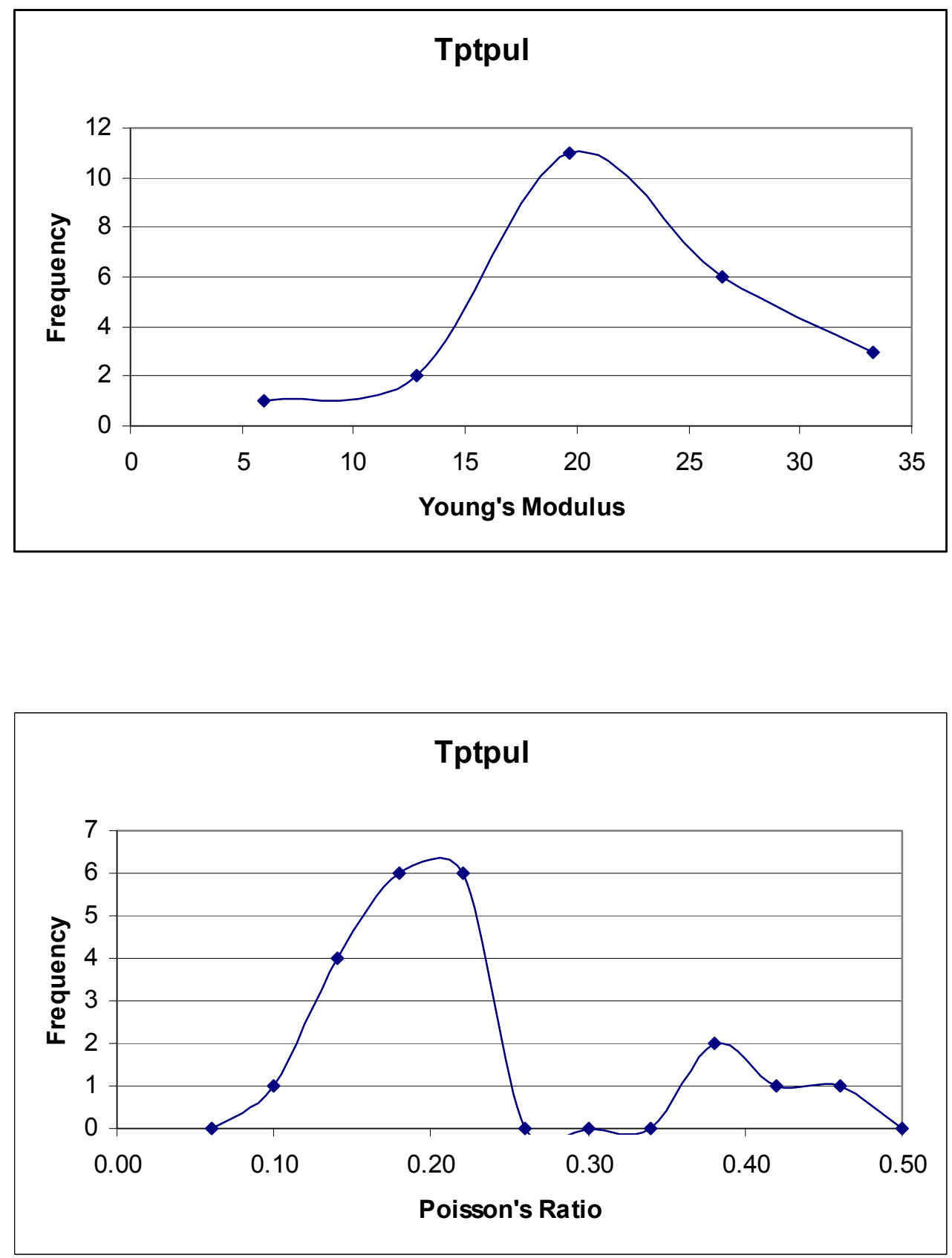

NOTE: Frequency distribution includes all the Busted Butte samples individually.

Figure 7. Static Young's Modulus (GPa) and Poisson's Ratio Frequency Distribution for Tptpul 

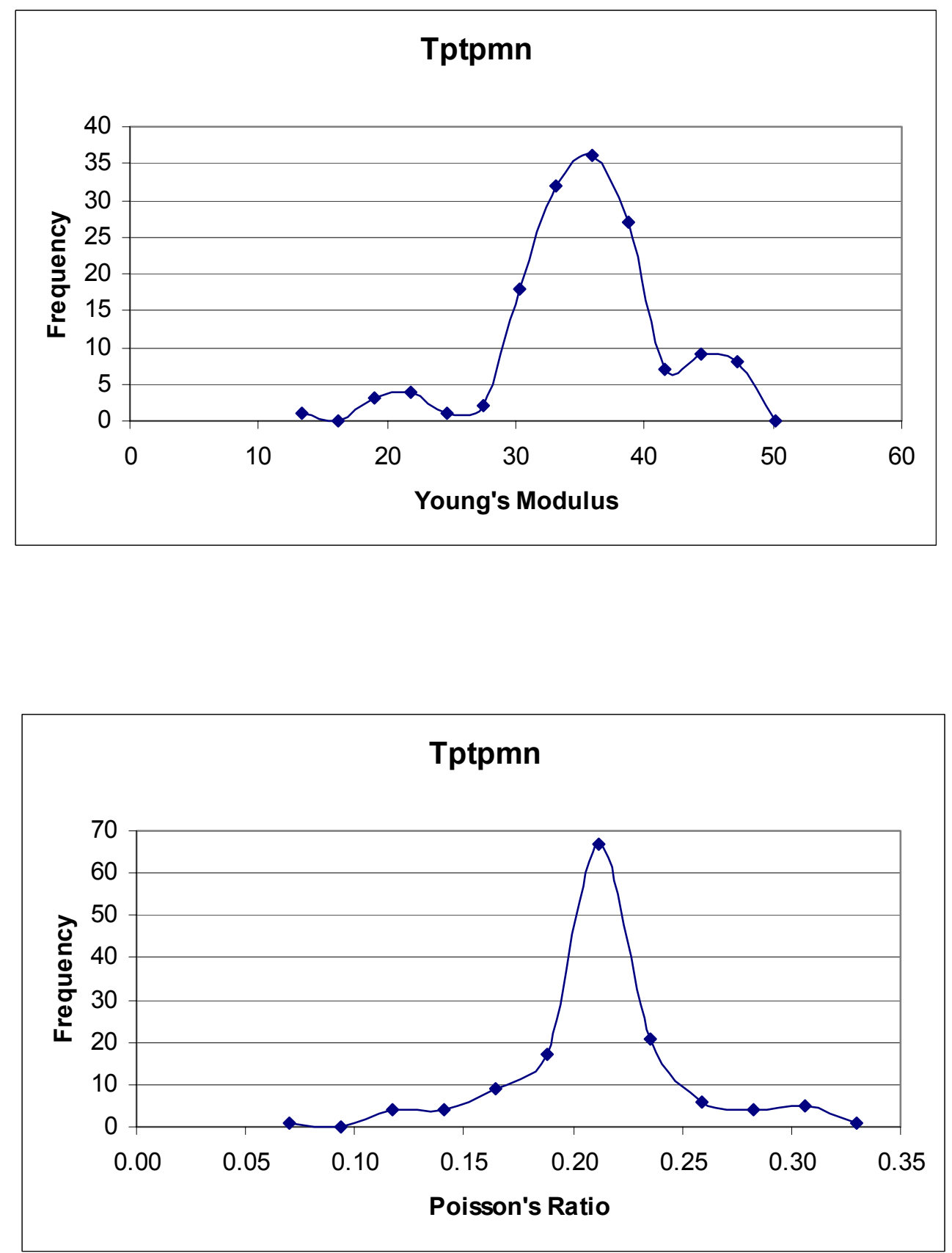

Note: Frequency distribution includes all values for Busted Butte individually. Samples are measured at room temperature and full saturation.

Figure 8. Static Young's Modulus (GPa) and Poisson's Ratio Frequency Distribution for Tptpmn 

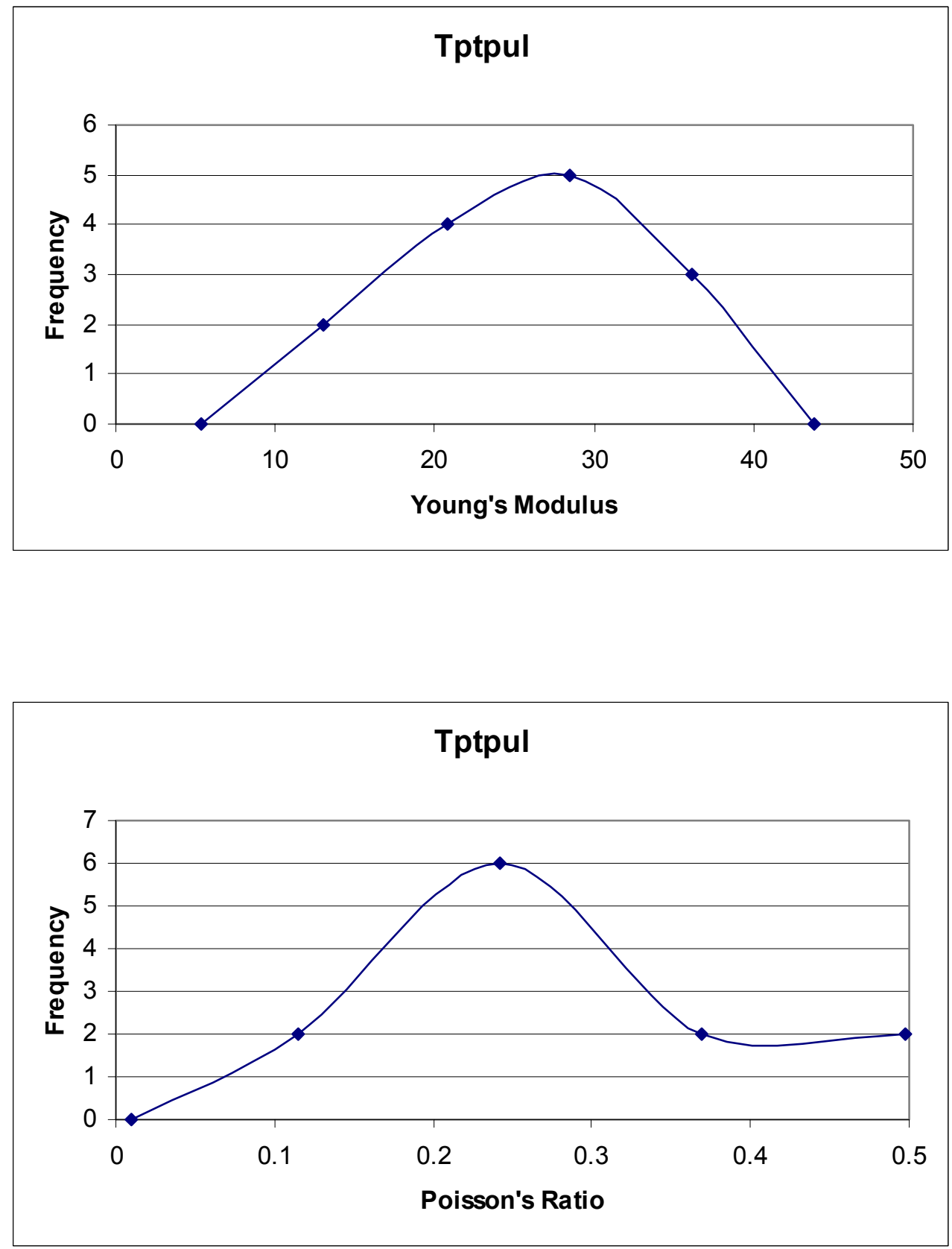

NOTE: Frequency distribution includes only one average value for the Busted Butte samples. Values were measured at room temperature and full saturation.

Figure 9. Static Young's Modulus (GPa) and Poisson's Ratio Frequency Distribution for Tptpul 

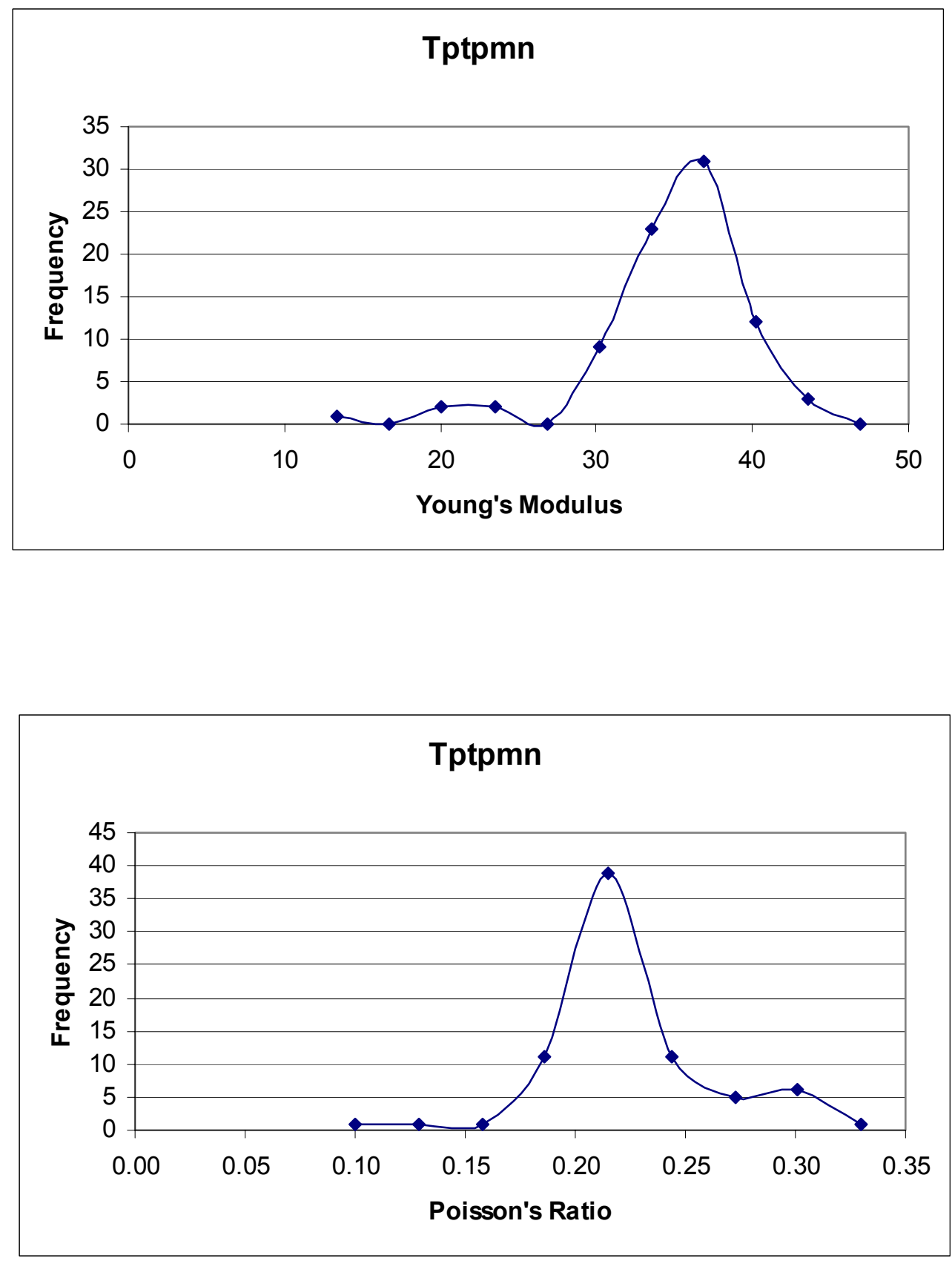

NOTE: Frequency distribution includes one average value for Busted Butte samples. Values were measured at room temperature and full saturation.

Figure 10. Static Young's Modulus (GPa) and Poisson's Ratio Frequency Distribution for Tptpmn 

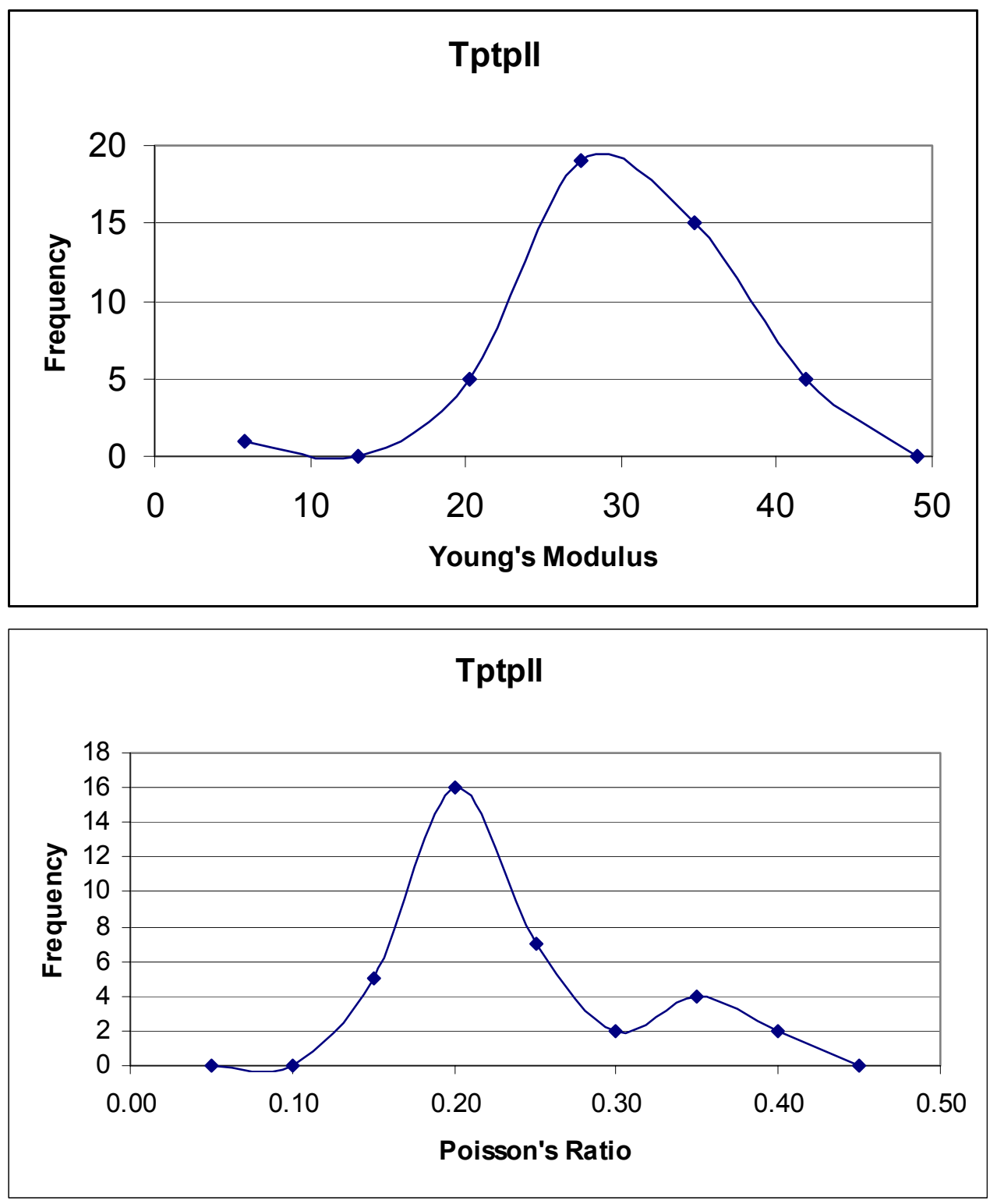

Note: Values were measured at room temperature and full saturation.

Figure 11. Static Young's Modulus (GPa) and Poisson's Ratio Frequency Distribution for Tptpll 

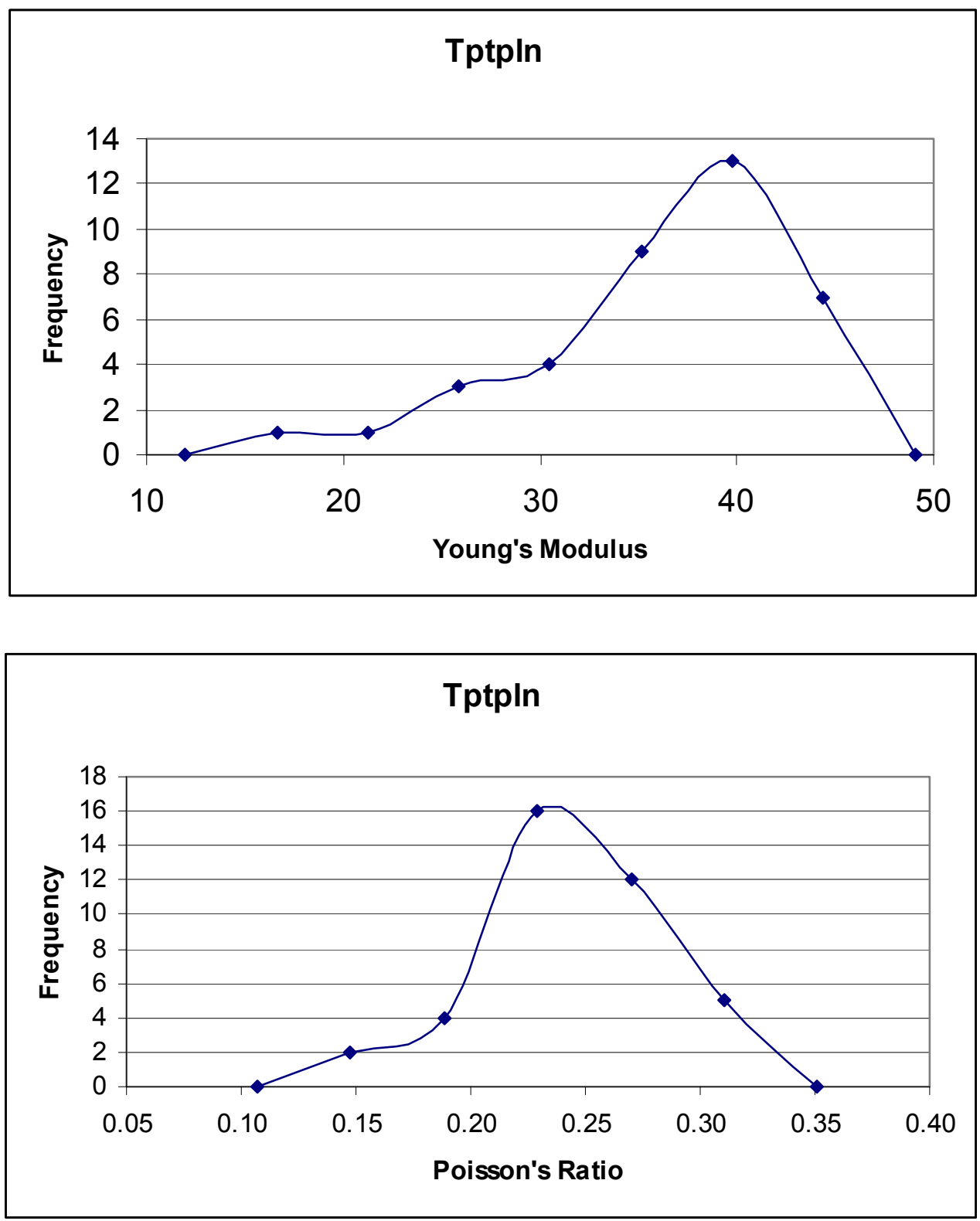

Note: Values were measured at room temperature and full saturation.

Figure 12. Static Young's Modulus (GPa) and Poisson's Ratio Frequency Distribution for Tptpln 

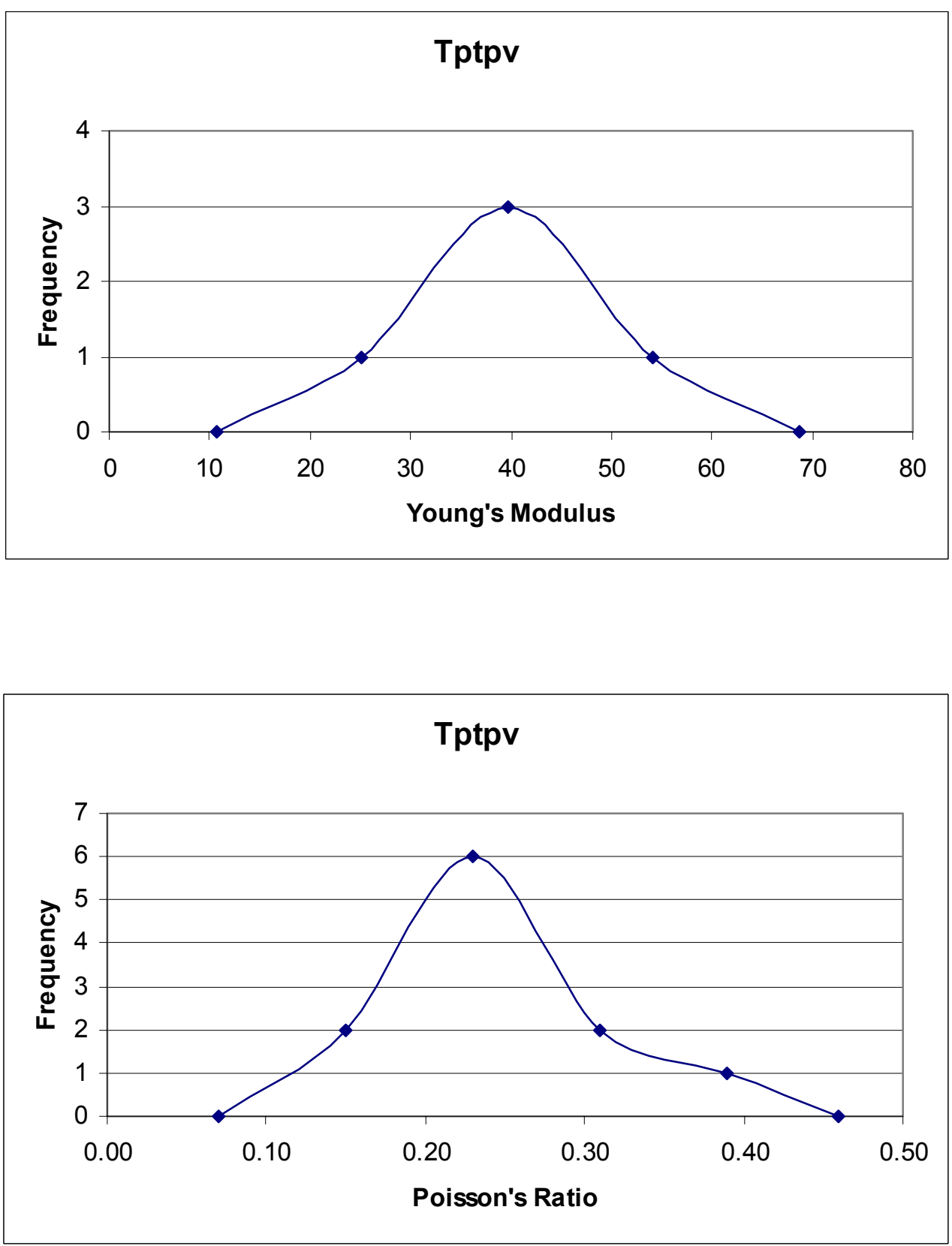

Note: Values were measured at room temperature and full saturation.

Figure 13. Static Young's Modulus (GPa) and Poisson's Ratio Frequency Distribution for Tptpv 

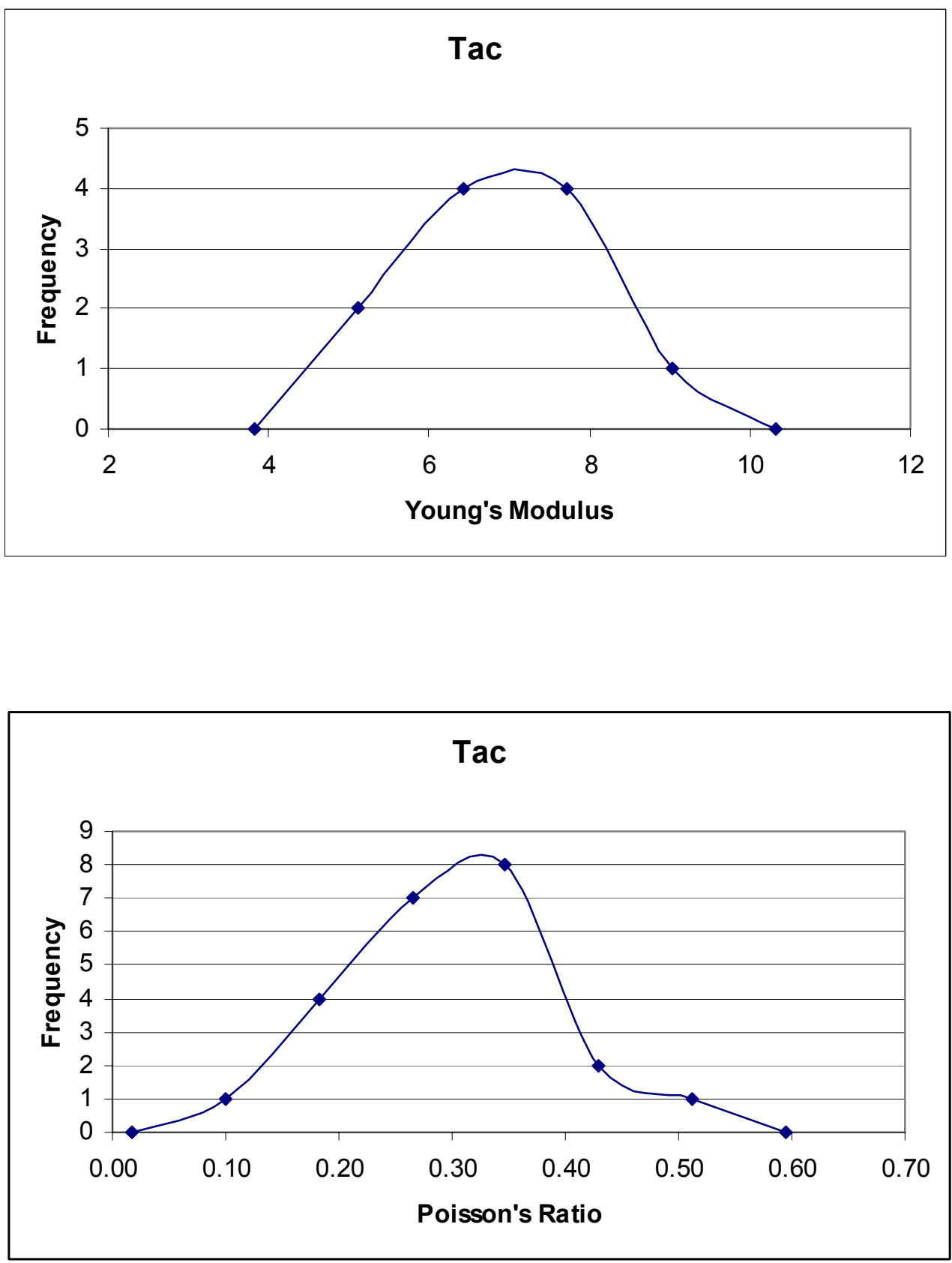

Note: Values were measured at room temperature and full saturation.

Figure 14. Static Young's Modulus (GPa) and Poisson's Ratio Frequency Distribution for Tac 
Table 1. DTNs Containing Potentially Relevant Data for Poisson's Ratio and Young's Modulus

\begin{tabular}{|c|c|c|c|c|c|c|}
\hline DTN & TITLE & DESCRIPTION & TYPE & \begin{tabular}{|l} 
STATUS \\
(AT \\
START \\
OF \\
REVIEW)
\end{tabular} & COMMENTS & DISPOSITION \\
\hline GS900983115212.001 & \begin{tabular}{|l|} 
REPORT ON \\
TELEVIEWER LOG \\
AND STRESS \\
MEASUREMENTS IN \\
CORE HOLE USW G- \\
1, NEVADA TEST \\
SITE, DECEMBER 13- \\
$22,1981$.
\end{tabular} & $\begin{array}{l}\text { BY J.H. HEALY, S.H. } \\
\text { HICKMAN, M.D. ZOBACK, } \\
\text { AND W.L. ELLIS }\end{array}$ & D & $\mathrm{U}$ & $\begin{array}{l}\text { USGS OFR 84-15 } \\
\text { (50 pages) No } \\
\text { values listed in } \\
\text { analysis of } \\
\text { televiewer log } \\
\text { data for stress } \\
\text { measurements }\end{array}$ & $\begin{array}{l}\text { No relevant } \\
\text { data } \\
\text { presented, not } \\
\text { used }\end{array}$ \\
\hline GS900983115212.002 & \begin{tabular}{|l|} 
REPORT ON \\
TELEVIEWER LOG \\
AND STRESS \\
MEASUREMENTS IN \\
CORE HOLE USW G- \\
2, NEVADA TEST \\
SITE, OCTOBER- \\
NOVEMBER 1982.
\end{tabular} & $\begin{array}{l}\text { BY J.M. STOCK, J.H. } \\
\text { HEALY, AND S.H. } \\
\text { HICKMAN }\end{array}$ & D & $\mathrm{U}$ & $\begin{array}{l}\text { USGS OFR 84- } \\
172 \text { (50 pages) } \\
\text { No values listed } \\
\text { in analysis of } \\
\text { televiewer log } \\
\text { data for stress } \\
\text { measurements }\end{array}$ & $\begin{array}{l}\text { No relevant } \\
\text { data } \\
\text { presented, not } \\
\text { used }\end{array}$ \\
\hline GS900983115212.003 & $\begin{array}{l}\text { REPORT ON } \\
\text { TELEVIEWER LOG } \\
\text { AND STRESS } \\
\text { MEASUREMENTS IN } \\
\text { HOLES USW G-3 } \\
\text { AND UE-25P1 (UE- } \\
\text { 25P \#1), YUCCA } \\
\text { MOUNTAIN, NYE } \\
\text { COUNTY, NEVADA. }\end{array}$ & $\begin{array}{l}\text { BY J.M. STOCK, J.H. } \\
\text { HEALY, J. SVITEK, AND L. } \\
\text { MASTIN }\end{array}$ & D & U & $\begin{array}{l}\text { USGS OFR 86- } \\
369 \text { (96 pages) } \\
\text { No values listed } \\
\text { in analysis of } \\
\text { televiewer log } \\
\text { data for stress } \\
\text { measurements }\end{array}$ & $\begin{array}{l}\text { No relevant } \\
\text { data } \\
\text { presented, not } \\
\text { used }\end{array}$ \\
\hline GS920983114220.001 & $\begin{array}{l}\text { LOG OF TEST PIT OR } \\
\text { AUGER HOLE, } \\
\text { PHYSICAL } \\
\text { PROPERTIES } \\
\text { SUMMARY, } \\
\text { GRADATION TEST, } \\
\text { AND SUMMARY OF } \\
\text { PHYSICAL } \\
\text { PROPERTIES TEST } \\
\text { RESULTS FOR HOLE } \\
\text { NUMBERS NRSF-TP- } \\
\text { 11, TP-19, TP-21, TP- } \\
\text { 25, TP-28, TP-29, } \\
\text { AND TP-30. }\end{array}$ & $\begin{array}{l}\text { LOG OF TEST PIT OR } \\
\text { AUGER HOLE, PHYSICAL } \\
\text { PROPERTIES SUMMARY, } \\
\text { GRADATION TEST, AND } \\
\text { SUMMARY OF PHYSICAL } \\
\text { PROPERTIES TEST } \\
\text { RESULTS FOR HOLE } \\
\text { NUMBERS NRSF-TP-11, } \\
\text { TP-19, TP-21, TP-25, TP- } \\
\text { 28, TP-29, AND TP-30. }\end{array}$ & $A$ & Q & $\begin{array}{l}66 \text { page text and } \\
\text { graphics. No } \\
\text { values listed in } \\
\text { analysis of log } \\
\text { data for physical } \\
\text { properties } \\
\text { measurements }\end{array}$ & $\begin{array}{l}\text { Material not } \\
\text { related, not } \\
\text { used }\end{array}$ \\
\hline
\end{tabular}


Table 1. DTNs Containing Potentially Relevant Data for Poisson's Ratio and Young's Modulus (Continued)

\begin{tabular}{|c|c|c|c|c|c|c|}
\hline DTN & TITLE & DESCRIPTION & TYPE & $\begin{array}{l}\text { STATUS } \\
\text { (AT } \\
\text { START } \\
\text { OF } \\
\text { REVIEW) }\end{array}$ & COMMENTS & DISPOSITION \\
\hline GS920983114220.002 & $\begin{array}{l}\text { DRILL HOLE UE-25 } \\
\text { NRG-1 ROCK CORE } \\
\text { TESTS. }\end{array}$ & \begin{tabular}{|l|} 
SPLITTING TENSILE \\
STRENGTH OF INTACT \\
ROCK CORE SPECIMENS, \\
DIRECT SHEAR TEST \\
RESULTS - OPEN JOINT \\
SLIDING FRICTION, \\
PULSE VELOCITIES AND \\
ULTRASONIC ELASTIC \\
CONSTANTS OF INTACT \\
ROCK CORE TEST \\
SPECIMENS, UNIAXIAL \\
COMPRESSION AND \\
ELASTIC PROPERTIES OF \\
INTACT ROCK CORE \\
TEST SPECIMENS.
\end{tabular} & A & Q & $\begin{array}{l}\text { Drill hole UE-25 } \\
\text { NRG-1 rock core } \\
\text { tests: summaries } \\
\text { of pulse velocities } \\
\text { and ultrasonic } \\
\text { elastic constants } \\
\text { of intact rock core } \\
\text { test specimens } \\
\text { ( } 20 \text { values), } \\
\text { uniaxial } \\
\text { compression and } \\
\text { elastic properties } \\
\text { of intact rock core } \\
\text { test specimens } \\
\text { (10 values). } \\
\text { Values by sample } \\
\text { number and } \\
\text { depth }\end{array}$ & $\begin{array}{l}\text { Repeats or } \\
\text { Summarizes } \\
\text { data in } \\
\text { GS921283114 } \\
\text { 220.008, not } \\
\text { used }\end{array}$ \\
\hline GS921283114220.003 & $\begin{array}{l}\text { RELATIVE DENSITY } \\
\text { DETERMINATION, } \\
\text { LAB TESTS OF } \\
\text { PHYSICAL } \\
\text { PROPERTIES, } \\
\text { NORTH RAMP. } \\
\end{array}$ & $\begin{array}{l}\text { RELATIVE DENSITY } \\
\text { DETERMINATION, LAB } \\
\text { TESTS OF PHYSICAL } \\
\text { PROPERTIES, NORTH } \\
\text { RAMP. }\end{array}$ & $A$ & Q & $\begin{array}{l}\text { Rock property } \\
\text { measurements } \\
\text { performed by } \\
\text { Bureau of } \\
\text { Reclamation on } \\
\text { YM samples. } \\
\end{array}$ & $\begin{array}{l}\text { Material not } \\
\text { related, not } \\
\text { used }\end{array}$ \\
\hline GS921283114220.004 & $\begin{array}{l}\text { SUMMARY ACCESS } \\
\text { ROAD TEST PIT } \\
\text { DATA, LOGS OF } \\
\text { VISUAL } \\
\text { OBSERVATIONS OF } \\
\text { SITE AND TEST PIT. }\end{array}$ & $\begin{array}{l}\text { SUMMARY ACCESS } \\
\text { ROAD TEST PIT DATA, } \\
\text { LOGS OF VISUAL } \\
\text { OBSERVATIONS OF SITE } \\
\text { AND TEST PIT. FIELD } \\
\text { TESTS OF PHYSICAL } \\
\text { PROPERTIES, NORTH } \\
\text { RAMP. }\end{array}$ & A & Q & $\begin{array}{l}\text { Logs of test pit or } \\
\text { auger holes, } \\
\text { GSF-TP-1 } \\
\text { through GSF-TP- } \\
\text { 39, dated } \\
091592-092292, \\
\text { access road, } \\
\text { ground surface } \\
\text { facility }\end{array}$ & $\begin{array}{l}\text { Material not } \\
\text { related, not } \\
\text { used }\end{array}$ \\
\hline GS921283114220.005 & $\begin{array}{l}\text { PHYSICAL } \\
\text { PROPERTIES AND } \\
\text { DIMENSIONAL } \\
\text { TOLERANCE } \\
\text { CONFORMANCE OF } \\
\text { ROCK CORE TEST } \\
\text { SPECIMENS. }\end{array}$ & $\begin{array}{l}\text { LAB TESTS OF PHYSICAL } \\
\text { PROPERTIES, NORTH } \\
\text { RAMP. }\end{array}$ & A & Q & $\begin{array}{l}\text { Tables of } \\
\text { moisture content } \\
\text { and physical } \\
\text { properties values } \\
\text { from the North } \\
\text { Ramp. Does not } \\
\text { contain Poisson } \\
\text { or Young's } \\
\text { values. }\end{array}$ & $\begin{array}{l}\text { Material not } \\
\text { related, not } \\
\text { used }\end{array}$ \\
\hline GS921283114220.006 & $\begin{array}{l}\text { PULSE VELOCITIES } \\
\text { AND ULTRASONIC } \\
\text { ELASTIC } \\
\text { CONSTANTS OF } \\
\text { INTACT ROCK CORE } \\
\text { TEST SPECIMENS. } \\
\end{array}$ & $\begin{array}{l}\text { LAB TESTS OF PHYSICAL } \\
\text { PROPERTIES, NORTH } \\
\text { RAMP. }\end{array}$ & A & QNV & $\begin{array}{l}\text { Pages 1-10 } \\
\text { contain Poisson } \\
\text { and Young's } \\
\text { values for } \\
\text { samples collected } \\
\text { from North Ramp } \\
\end{array}$ & Directly Used \\
\hline GS921283114220.008 & $\begin{array}{l}\text { UNIAXIAL } \\
\text { COMPRESSION AND } \\
\text { ELASTIC } \\
\text { PROPERTIES OF } \\
\text { INTACT ROCK CORE } \\
\text { SPECIMENS FROM } \\
\text { UE-25 NRG\#1. }\end{array}$ & $\begin{array}{l}\text { UNIAXIAL COMPRESSION } \\
\text { AND ELASTIC } \\
\text { PROPERTIES OF INTACT } \\
\text { ROCK CORE SPECIMENS. } \\
\text { LAB TESTS OF } \\
\text { MECHANICAL } \\
\text { PROPERTIES, NORTH } \\
\text { RAMP. }\end{array}$ & A & QNV & $\begin{array}{l}\text { Poisson ratios for } \\
\text { various intact rock } \\
\text { core samples } \\
\text { from UE-25 } \\
\text { NRG\#1 and North } \\
\text { Ramp }\end{array}$ & Directly Used \\
\hline
\end{tabular}


Table 1. DTNs Containing Potentially Relevant Data for Poisson's Ratio and Young's Modulus (Continued)

\begin{tabular}{|c|c|c|c|c|c|c|}
\hline DTN & TITLE & DESCRIPTION & TYPE & $\begin{array}{l}\text { STATUS } \\
\text { (AT } \\
\text { START } \\
\text { OF } \\
\text { REVIEW) }\end{array}$ & COMMENTS & DISPOSITION \\
\hline GS921283114220.009 & $\begin{array}{l}\text { TRIAXIAL } \\
\text { COMPRESSION AND } \\
\text { ELASTIC } \\
\text { PROPERTIES OF } \\
\text { INTACT ROCK CORE } \\
\text { TEST SPECIMENS } \\
\text { FROM UE-25 NRG\#1. }\end{array}$ & $\begin{array}{l}\text { LAB TESTS OF } \\
\text { MECHANICAL } \\
\text { PROPERTIES, NORTH } \\
\text { RAMP. }\end{array}$ & A & QNV & $\begin{array}{l}\text { Poisson ratios for } \\
\text { various intact rock } \\
\text { core samples } \\
\text { from UE-25 } \\
\text { NRG\#1 and North } \\
\text { Ramp }\end{array}$ & $\begin{array}{l}\text { Status } \\
\text { changed to } \\
\text { unqualified. } \\
\text { Corroborating, } \\
\text { unable to } \\
\text { qualify, data } \\
\text { not used. }\end{array}$ \\
\hline GS921283114220.014 & $\begin{array}{l}\text { SOIL AND ROCK } \\
\text { GEOTECHNICAL } \\
\text { INVESTIGATIONS, } \\
\text { FIELD AND } \\
\text { LABORATORY } \\
\text { STUDIES, NORTH } \\
\text { RAMP SURFACE } \\
\text { FACILITY, } \\
\text { EXPLORATORY } \\
\text { STUDIES FACILITY, } \\
\text { YUCCA MOUNTAIN } \\
\text { PROJECT, NEVADA. }\end{array}$ & $\begin{array}{l}\text { BY MARK H. MCKEOWN } \\
\text { AND STEVE C. BEASON }\end{array}$ & D & Q & $\begin{array}{l}\text { Report contains } \\
\text { the spreadsheets } \\
\text { for uniaxial and } \\
\text { triaxial properties. }\end{array}$ & $\begin{array}{l}\text { Repeats or } \\
\text { Summarizes } \\
\text { GS921283114 } \\
220.006, \text { not } \\
\text { used }\end{array}$ \\
\hline GS940408312232.010 & $\begin{array}{l}\text { ELASTIC WAVE } \\
\text { VELOCITY } \\
\text { MEASUREMENTS IN } \\
\text { PLUG CORE } \\
\text { SAMPLES FROM } \\
\text { BOREHOLE UE-25 UZ } \\
\# 16\end{array}$ & $\begin{array}{l}\text { ELASTIC WAVE } \\
\text { VELOCITY } \\
\text { MEASUREMENTS IN } \\
\text { PLUG CORE SAMPLES } \\
\text { FROM BOREHOLE UE-25 } \\
\text { UZ\#16, YUCCA } \\
\text { MOUNTAIN, NYE } \\
\text { COUNTY, NEVADA }\end{array}$ & $A$ & QNV & $\begin{array}{l}\text { Page } 30 \text { contains } \\
\text { Poisson and } \\
\text { Young's values } \\
\text { from UE-25 } \\
\text { UZ\#16 plug core } \\
\text { samples. }\end{array}$ & Directly Used \\
\hline LL000209404243.036 & $\begin{array}{l}\text { GEOMECHANICAL } \\
\text { CHARACTERIZATION } \\
\text { OF LARGE BLOCK } \\
\text { CORE SPECIMENS } \\
\end{array}$ & $\begin{array}{l}\text { HEATER VOLTAGES AND } \\
\text { COMPRESSION TEST } \\
\text { DATA. DATA HAVE BEEN } \\
\text { SUPERSEDED BY DATA } \\
\text { IDENTIFIED WITH DTN } \\
\text { LL010700823123.014. } \\
\end{array}$ & A & $\mathrm{U}$ & $\begin{array}{l}\text { Superseded by } \\
\text { LL010700823123 } \\
.014\end{array}$ & $\begin{array}{l}\text { Superseded, } \\
\text { not used }\end{array}$ \\
\hline LL000314151021.122 & $\begin{array}{l}\text { CLAD DEGRADATION } \\
\text { - WET UNZIPPING } \\
\end{array}$ & $\begin{array}{l}\text { MECHANICAL } \\
\text { PROPERTIES OF } \\
\text { ZIRCALOY-2 AND } \\
\text { ZIRCALOY-4. } \\
\end{array}$ & $A$ & $\mathrm{U}$ & No links provided & $\begin{array}{l}\text { Material not } \\
\text { related, not } \\
\text { used }\end{array}$ \\
\hline LL010700823123.014 & $\begin{array}{l}\text { GEOMECHANICAL } \\
\text { CHARACTERIZATION } \\
\text { OF LARGE BLOCK } \\
\text { CORE SPECIMENS. }\end{array}$ & $\begin{array}{l}\text { HEATER VOLTAGES AND } \\
\text { COMPRESSION TEST } \\
\text { DATA. THESE DATA } \\
\text { SUPERSEDE DATA } \\
\text { PREVIOUSLY IDENTIFIED } \\
\text { BY DTN } \\
\text { LL000209404243.036. }\end{array}$ & A & Q & $\begin{array}{l}\text { No Data } \\
\text { Submitted }\end{array}$ & $\begin{array}{l}\text { No Data } \\
\text { Submitted, not } \\
\text { used }\end{array}$ \\
\hline LL9503RIB0031A.000 & $\begin{array}{l}\text { RIB ITEM\#31A/REV0: } \\
\text { WASTE PACKAGE } \\
\text { PROPERTIES AND } \\
\text { ENVIRONMENT: } \\
\text { WASTE PACKAGE } \\
\text { MECHANICAL } \\
\text { PROPERTIES (ALLOY } \\
\text { 825 AND CARBON } \\
\text { STEEL). }\end{array}$ & $\begin{array}{l}\text { THESE DATA HAVE BEEN } \\
\text { SUPERSEDED BY DTN: } \\
\text { LL9708RIB0031A.001. }\end{array}$ & A & Q & $\begin{array}{l}\text { Superseded by } \\
\text { LL9708RIB0031A } \\
.001\end{array}$ & $\begin{array}{l}\text { Superseded, } \\
\text { not used }\end{array}$ \\
\hline
\end{tabular}


Table 1. DTNs Containing Potentially Relevant Data for Poisson's Ratio and Young's Modulus (Continued)

\begin{tabular}{|c|c|c|c|c|c|c|}
\hline DTN & TITLE & DESCRIPTION & TYPE & $\begin{array}{l}\text { STATUS } \\
\text { (AT } \\
\text { START } \\
\text { OF } \\
\text { REVIEW) }\end{array}$ & COMMENTS & DISPOSITION \\
\hline LL950712904243.000 & $\begin{array}{l}\text { EFFECTS OF } \\
\text { RADIATION ON } \\
\text { GEOMECHANICAL } \\
\text { PROPERTIES OF } \\
\text { TOPOPAH SPRING } \\
\text { TUFF. }\end{array}$ & $\begin{array}{l}\text { LETTER REPORT ON } \\
\text { PRELIMINARY DATA. VA } \\
\text { SUPPORTING DATA. }\end{array}$ & $A$ & $\mathrm{U}$ & $\begin{array}{l}\text { Young's values } \\
\text { from core } \\
\text { samples of } \\
\text { Topopah Springs } \\
\text { Tuff used to } \\
\text { determine the } \\
\text { effects of } \\
\text { radiation on } \\
\text { mechanical } \\
\text { properties. }\end{array}$ & $\begin{array}{l}\text { Repeats or } \\
\text { summarizes } \\
\text { Same data as } \\
\text { LL9902053042 } \\
43.032 \text { (Q } \\
\text { version), not } \\
\text { used }\end{array}$ \\
\hline LL960201104243.006 & $\begin{array}{l}\text { RESULTS FROM THE } \\
\text { UNIAXIAL TESTS ON } \\
\text { SAMPLES OF } \\
\text { TOPOPAH SPRING } \\
\text { TUFF. }\end{array}$ & $\begin{array}{l}\text { ONE TABLE WHICH } \\
\text { PROVIDES THE PEAK } \\
\text { STRENGTH, YOUNG'S } \\
\text { MODULUS, IRRADIATION } \\
\text { SPECIFICATION, AND } \\
\text { GENERAL COMMENTS } \\
\text { ON THE BEHAVIOR OF } \\
\text { THE SAMPLE DURING } \\
\text { TESTING. }\end{array}$ & D & $U$ & $\begin{array}{l}\text { s96376_002 } \\
\text { DATA REPORT } \\
\text { TABLE } \\
\text { DESCRIPTION: } \\
\text { Young's Modulus } \\
\text { data on Topopah } \\
\text { Spring Tuff from } \\
\text { the Large Block } \\
\text { Test Site at Fran } \\
\text { Ridge }\end{array}$ & $\begin{array}{l}\text { Repeats or } \\
\text { summarizes } \\
\text { LL9507129042 } \\
43.000, \text { not } \\
\text { used }\end{array}$ \\
\hline LL960401604243.007 & $\begin{array}{l}\text { PROCEDURE TAKEN } \\
\text { TO TEST } \\
\text { IRRADIATED AND } \\
\text { NON-IRRADIATED } \\
\text { CORE SAMPLES } \\
\text { FROM FRAN RIDGE. }\end{array}$ & $\begin{array}{l}\text { SCIENTIFIC NOTEBOOK } \\
\text { DESCRIBING THE } \\
\text { PROCEDURE. }\end{array}$ & $A$ & U & $\begin{array}{l}\text { Procedure for } \\
\text { uniaxial stress } \\
\text { measurements } \\
\text { available in } \\
\text { LL960201104243 } \\
.006\end{array}$ & $\begin{array}{l}\text { Supporting } \\
\text { records, not } \\
\text { used }\end{array}$ \\
\hline LL960401704243.008 & $\begin{array}{l}\text { EFFECT OF } \\
\text { RADIATION ON THE } \\
\text { MECHANICAL } \\
\text { PROPERTIES OF } \\
\text { TOPOPAH SPRING } \\
\text { TUFF. }\end{array}$ & INFORMAL REPORT. & D & $\mathrm{U}$ & $\begin{array}{l}\text { Informal report on } \\
\text { the effect of } \\
\text { radiation on tuff. } \\
\text { Summarizes the } \\
\text { notebook data. }\end{array}$ & $\begin{array}{l}\text { Repeats or } \\
\text { Summarizes } \\
\text { LL9902053042 } \\
43.032, \text { not } \\
\text { used }\end{array}$ \\
\hline LL960807504241.012 & $\begin{array}{l}\text { VOLUME II: NEAR- } \\
\text { FIELD AND } \\
\text { ALTERED-ZONE } \\
\text { ENVIRONMENT } \\
\text { REPORT. }\end{array}$ & $\begin{array}{l}\text { CH. 4-GEOMECHANICS } \\
\text { BY S. BLAIR AND P. } \\
\text { BERGE, VA SUPPORTING } \\
\text { DATA. }\end{array}$ & $D$ & $\mathrm{U}$ & $\begin{array}{l}\text { Volume II: } 995 \\
\text { page report } \\
\text { summarizing } \\
\text { Near Field and } \\
\text { Altered Zone } \\
\text { Environment. See } \\
\text { Table 4-4 and 4-7 }\end{array}$ & $\begin{array}{l}\text { Repeats or } \\
\text { summarizes } \\
\text { values taken } \\
\text { from other } \\
\text { sources, not } \\
\text { used }\end{array}$ \\
\hline LL960905005911.010 & $\begin{array}{l}\text { ENGINEERED } \\
\text { MATERIALS } \\
\text { CHARACTERIZATION } \\
\text { REPORT FOR THE } \\
\text { YUCCA MOUNTAIN } \\
\text { SITE } \\
\text { CHARACTERIZATION } \\
\text { PROJECT. }\end{array}$ & $\begin{array}{l}\text { INFORMAL REPORT. } \\
\text { VOLUME 1, } \\
\text { INTRODUCTION, } \\
\text { HISTORY \& CURRENT } \\
\text { CANDIDATES. VOLUME 2, } \\
\text { DESIGN DATA. VOLUME } \\
\text { 3, CORROSION DATA } \\
\text { AND MODELING. VA } \\
\text { SUPPORTING DATA. }\end{array}$ & $A$ & $\mathrm{U}$ & $\begin{array}{l}\text { Design Data: } \\
\text { Physical } \\
\text { properties of } \\
\text { engineered } \\
\text { design materials. } \\
\text { No rock property } \\
\text { data included. }\end{array}$ & $\begin{array}{l}\text { Material not } \\
\text { related, not } \\
\text { used }\end{array}$ \\
\hline LL970203704243.010 & $\begin{array}{l}\text { EFFECT OF } \\
\text { RADIATION ON } \\
\text { TOPOPAH SPRING } \\
\text { TUFF MECHANICAL } \\
\text { PROPERTIES. }\end{array}$ & $\begin{array}{l}\text { CONFERENCE REPORT. } \\
\text { VA SUPPORTING DATA. }\end{array}$ & D & $\mathrm{U}$ & $\begin{array}{l}\text { UCRL-JC-124343 } \\
\text { Final report on } \\
\text { the effect of } \\
\text { radiation on tuff. } \\
\text { Summarizes } \\
\text { notebook data } \\
\text { LL960401604243 } \\
.007\end{array}$ & $\begin{array}{l}\text { Repeats or } \\
\text { Summarizes } \\
\text { LL9902053042 } \\
43.032, \text { not } \\
\text { used }\end{array}$ \\
\hline
\end{tabular}


Table 1. DTNs Containing Potentially Relevant Data for Poisson's Ratio and Young's Modulus (Continued)

\begin{tabular}{|c|c|c|c|c|c|c|}
\hline DTN & TITLE & DESCRIPTION & TYPE & $\begin{array}{l}\text { STATUS } \\
\text { (AT } \\
\text { START } \\
\text { OF } \\
\text { REVIEW) }\end{array}$ & COMMENTS & DISPOSITION \\
\hline LL9708RIB0031A.001 & $\begin{array}{l}\text { ENGINEERED } \\
\text { MATERIALS } \\
\text { CHARACTERISTICS }\end{array}$ & $\begin{array}{l}\text { RIB ITEM\#31A/REV1: } \\
\text { ENGINEERED MATERIALS } \\
\text { CHARACTERISTICS: } \\
\text { WASTE PACKAGE } \\
\text { MECHANICAL } \\
\text { PROPERTIES. (THESE } \\
\text { DATA SUPERSEDE DATA } \\
\text { PREVIOUSLY IDENTIFIED } \\
\text { BY DTN'S : } \\
\text { LL9503RIB0031A.000 AND } \\
\text { LL9503RIB0033A.000) } \\
\text { (THESE DATA WERE } \\
\text { SUPERSEDED BY DATA } \\
\text { IDENTIFIED WITH DTNS: } \\
\text { MO9906RIB00052.000 } \\
\text { MO9906RIB00053.000). } \\
\end{array}$ & D & Q & $\begin{array}{l}\text { RIB Item } \\
\text { superseded by } \\
\text { M\&O RIB Items }\end{array}$ & $\begin{array}{l}\text { Superceded, } \\
\text { not used }\end{array}$ \\
\hline LL980200604241.013 & $\begin{array}{l}\text { NEAR-FIELD AND } \\
\text { ALTERED-ZONE } \\
\text { ENVIRONMENT } \\
\text { REPORT VOLUME I: } \\
\text { TECHNICAL BASES } \\
\text { FOR EBS DESIGN, } \\
\text { REVISION } 1 .\end{array}$ & $\begin{array}{l}\text { LETTER REPORT. VA } \\
\text { SUPPORTING DATA. }\end{array}$ & D & $U$ & $\begin{array}{l}\text { UCRL-LR-124998 } \\
\text { NEAR-FIELD } \\
\text { AND ALTERED- } \\
\text { ZONE } \\
\text { ENVIRONMENT } \\
\text { REPORT } \\
\text { VOLUME 1: } \\
\text { TECHNICAL } \\
\text { BASES FOR EBS } \\
\text { DESIGN }\end{array}$ & $\begin{array}{l}\text { Repeats or } \\
\text { Summarizes, } \\
\text { not used }\end{array}$ \\
\hline LL980208104243.019 & $\begin{array}{l}\text { MECHANICAL } \\
\text { PROPERTIES OF } \\
\text { TOPOPAH SPRING } \\
\text { HOST ROCK, AND } \\
\text { FRACTURES IN THE } \\
\text { HOST ROCK. }\end{array}$ & $\begin{array}{l}\text { TABLE BASED ON } \\
\text { LABORATORY } \\
\text { EXPERIMENTS ON CORE } \\
\text { SAMPLES AND SMALL } \\
\text { (NOMINAL O.5-M) TUFF } \\
\text { BLOCKS AT LAWRENCE } \\
\text { LIVERMORE NATIONAL } \\
\text { LABORATORY. }\end{array}$ & D & $U$ & $\begin{array}{l}\text { Can be } \\
\text { considered a } \\
\text { creep test (matrix } \\
+ \text { fracture). } \\
\text { Values of Young's } \\
\text { Modulus data via } \\
\text { laboratory } \\
\text { measurements of } \\
\text { Topopah Spring } \\
\text { host rock and } \\
\text { fractures within } \\
\text { the host rock }\end{array}$ & $\begin{array}{l}\text { No relevant } \\
\text { data } \\
\text { presented, not } \\
\text { used }\end{array}$ \\
\hline LL980802204243.020 & $\begin{array}{l}\text { RESULTS OF A } \\
\text { COUPLED } \\
\text { FRACTURE-FLOW } \\
\text { TEST AT THE 0.5-M } \\
\text { SCALE. }\end{array}$ & $\begin{array}{l}\text { SIX TABLES AND ONE } \\
\text { FIGURE FOR MILESTONE } \\
\text { REPORT \#SPLL37M4. VA } \\
\text { SUPPORTING DATA. }\end{array}$ & D & $\mathrm{U}$ & $\begin{array}{l}\text { Young's Modulus } \\
\text { data of rock strain } \\
\text { for a coupled } \\
\text { fracture-flow test } \\
\text { at the } 0.5 \text { meter } \\
\text { scale, }\end{array}$ & $\begin{array}{l}\text { No relevant } \\
\text { data } \\
\text { presented, not } \\
\text { used }\end{array}$ \\
\hline LL981208504243.031 & $\begin{array}{l}\text { EFFECT OF } \\
\text { RADIATION ON } \\
\text { TOPOPAH SPRING } \\
\text { TUFF MECHANICAL } \\
\text { PROPERTIES. }\end{array}$ & $\begin{array}{l}\text { TWO TABLES AND TWO } \\
\text { FIGURES OF DATA. VA } \\
\text { SUPPORTING DATA. }\end{array}$ & $A$ & Q & $\begin{array}{l}\text { Mechanical } \\
\text { Properties data } \\
\text { from uniaxial tests } \\
\text { of radiation } \\
\text { effects on } \\
\text { Topopah Spring } \\
\text { tuff samples }\end{array}$ & $\begin{array}{l}\text { Repeats or } \\
\text { summarizes } \\
\text { Same data as } \\
\text { LL9902053042 } \\
43.032, \text { not } \\
\text { used }\end{array}$ \\
\hline LL981212005924.062 & \begin{tabular}{|l|} 
DEGRADATION \\
MODE SURVEY \\
CANDIDATE \\
TITANIUM-BASE \\
ALLOYS FOR YUCCA \\
MOUNTAIN PROJECT \\
WASTE PACKAGE \\
\end{tabular} & $\begin{array}{l}\text { 15 TABLES, } 8 \text { FIGURES. } \\
\text { UCRL-ID-121191 }\end{array}$ & A & $\mathrm{U}$ & $\begin{array}{l}\text { Data on waste } \\
\text { package } \\
\text { materials }\end{array}$ & $\begin{array}{l}\text { Material not } \\
\text { related, not } \\
\text { used }\end{array}$ \\
\hline
\end{tabular}


Table 1. DTNs Containing Potentially Relevant Data for Poisson's Ratio and Young's Modulus (Continued)

\begin{tabular}{|c|c|c|c|c|c|c|}
\hline DTN & TITLE & DESCRIPTION & TYPE & $\begin{array}{l}\text { STATUS } \\
\text { (AT } \\
\text { START } \\
\text { OF } \\
\text { REVIEW) }\end{array}$ & COMMENTS & DISPOSITION \\
\hline & MATERIALS. & & & & & \\
\hline LL990202204241.036 & GEOMECHANICS. & $\begin{array}{l}\text { CHAPTER 4, VOL. II OF } \\
\text { NEAR FIELD AND } \\
\text { ALTERED ZONE } \\
\text { ENVIRONMENT REPORT. } \\
\text { SEVEN TABLES AND FIVE } \\
\text { FIGURES. }\end{array}$ & $A$ & Q & $\begin{array}{l}\text { Mechanical } \\
\text { Properties data of } \\
\text { intact rock for unit } \\
\text { TSw2, } \\
01 / 01 / 1991 \text { to } \\
08 / 01 / 1996 .\end{array}$ & $\begin{array}{l}\text { Repeats or } \\
\text { summarizes, } \\
\text { not used }\end{array}$ \\
\hline LL990205304243.032 & $\begin{array}{l}\text { EFFECT OF } \\
\text { RADIATION ON } \\
\text { STRENGTH OF } \\
\text { TOPOPAH SPRINGS } \\
\text { TUFF }\end{array}$ & $\begin{array}{l}\text { SEVENTEEN IMAGES } \\
\text { AND TWO TABLES. VA } \\
\text { SUPPORTING DATA. }\end{array}$ & $A$ & QNV & $\begin{array}{l}\text { Mechanical } \\
\text { Properties data } \\
\text { from uniaxial tests } \\
\text { of radiation } \\
\text { effects on } \\
\text { Topopah Spring } \\
\text { tuff samples }\end{array}$ & $\begin{array}{l}\text { Status } \\
\text { changed to } \\
\text { unqualified. } \\
\text { Corroborating, } \\
\text { unable to } \\
\text { qualify, data } \\
\text { not used. }\end{array}$ \\
\hline MO0003RIB00071.000 & $\begin{array}{l}\text { PHYSICAL AND } \\
\text { CHEMICAL } \\
\text { CHARACTERISTICS } \\
\text { OF ALLOY } 22\end{array}$ & $\begin{array}{l}\text { DATA DESCRIBING } \\
\text { PROPERTIES OF ALLOY } \\
\text { 22. THESE DATA } \\
\text { SUPERSEDE A PORTION } \\
\text { OF THE DATA } \\
\text { PREVIOUSLY IDENTIFIED } \\
\text { BY DTN: } \\
\text { MO9906RIB00052.000 } \\
\text { (ALL ALLOY } 22 \text { DATA) }\end{array}$ & D & Q & $\begin{array}{l}\text { Data on waste } \\
\text { package } \\
\text { materials }\end{array}$ & $\begin{array}{l}\text { Material not } \\
\text { related, not } \\
\text { used }\end{array}$ \\
\hline MO0003RIB00072.000 & $\begin{array}{l}\text { PHYSICAL AND } \\
\text { CHEMICAL } \\
\text { CHARACTERISTICS } \\
\text { OF STEEL, A } 516\end{array}$ & $\begin{array}{l}\text { DATA DESCRIBING } \\
\text { PROPERTIES OF STEEL } \\
\text { ALLOY 516. THESE DATA } \\
\text { SUPERSEDE A PORTION } \\
\text { OF THE DATA } \\
\text { PREVIOUSLY IDENTIFIED } \\
\text { BY DTN: } \\
\text { MO9906RIB00053.000 } \\
\text { (ALL ALLOY } 516 \text { DATA) } \\
\end{array}$ & D & Q & $\begin{array}{l}\text { Data on waste } \\
\text { package } \\
\text { materials }\end{array}$ & $\begin{array}{l}\text { Material not } \\
\text { related, not } \\
\text { used }\end{array}$ \\
\hline MO0003RIB00073.000 & $\begin{array}{l}\text { PHYSICAL AND } \\
\text { CHEMICAL } \\
\text { CHARACTERISTICS } \\
\text { OF TI GRADES } 7 \text { AND } \\
16 .\end{array}$ & $\begin{array}{l}\text { DATA DESCRIBING } \\
\text { PROPERTIES OF } \\
\text { TITANIUM ALLOY } \\
\text { GRADES } 7 \text { AND } 16 . \\
\text { THESE DATA } \\
\text { SUPERSEDE A PORTION } \\
\text { OF THE DATA } \\
\text { PREVIOUSLY IDENTIFIED } \\
\text { BY DTN: } \\
\text { MO9906RIB00052.000 } \\
\text { (ALL TITANIUM GRADES } 7 \\
\text { AND } 16 \text { DATA). }\end{array}$ & D & Q & $\begin{array}{l}\text { Data on waste } \\
\text { package } \\
\text { materials }\end{array}$ & $\begin{array}{l}\text { Material not } \\
\text { related, not } \\
\text { used }\end{array}$ \\
\hline
\end{tabular}


Table 1. DTNs Containing Potentially Relevant Data for Poisson's Ratio and Young's Modulus (Continued)

\begin{tabular}{|c|c|c|c|c|c|c|}
\hline DTN & TITLE & DESCRIPTION & TYPE & $\begin{array}{l}\text { STATUS } \\
\text { (AT } \\
\text { START } \\
\text { OF } \\
\text { REVIEW) }\end{array}$ & COMMENTS & DISPOSITION \\
\hline MO0003RIB00076.000 & $\begin{array}{l}\text { PHYSICAL AND } \\
\text { CHEMICAL } \\
\text { CHARACTERISTICS } \\
\text { OF TYPE 316N } \\
\text { GRADE }\end{array}$ & $\begin{array}{l}\text { DATA DESCRIBING } \\
\text { PROPERTIES OF TYPE } \\
\text { 316N GRADE STAINLESS } \\
\text { STEEL. THESE DATA } \\
\text { SUPERSEDE A PORTION } \\
\text { OF THE DATA } \\
\text { PREVIOUSLY IDENTIFIED } \\
\text { BY DTN: } \\
\text { MO9906RIB00054.000 } \\
\text { (ALL ALLOY 316N DATA) } \\
\end{array}$ & D & Q & $\begin{array}{l}\text { Data on waste } \\
\text { package } \\
\text { materials }\end{array}$ & $\begin{array}{l}\text { Material not } \\
\text { related, not } \\
\text { used }\end{array}$ \\
\hline MO0004SEPDFFVV.008 & $\begin{array}{l}\text { FREE-FIELD VALUES } \\
\text { OF SHEAR-WAVE } \\
\text { VELOCITY, } \\
\text { COMPRESSION- } \\
\text { WAVE VELOCITY, } \\
\text { POISSON'S RATIO, } \\
\text { AND MOIST DENSITY } \\
\text { AT BOREHOLE UE-25 } \\
\text { RF\#13. }\end{array}$ & $\begin{array}{l}\text { VALUES OF SHEAR- } \\
\text { WAVE VELOCITY, } \\
\text { COMPRESSION-WAVE } \\
\text { VELOCITY, POISSON'S } \\
\text { RATIO, AND MOIST } \\
\text { DENSITY FOR USE IN } \\
\text { PRELIMINARY FREE- } \\
\text { FIELD GROUND MOTION } \\
\text { ANALYSES AT } \\
\text { BOREHOLE UE-25 RF\#13. }\end{array}$ & D & $\mathrm{U}$ & $\begin{array}{l}\text { Stratigraphic unit, } \\
\text { Seismic S-Wave } \\
\text { Velocity, Seismic } \\
\text { P-Wave Velocity, } \\
\text { Poisson's Ratio } \\
\text { and Bulk Density } \\
\text { data of Free-Field } \\
\text { values for UE-25 } \\
\text { RF \#13 }\end{array}$ & $\begin{array}{l}\text { Repeats or } \\
\text { summarizes, } \\
\text { not used }\end{array}$ \\
\hline MO0006SPASTR01.003 & $\begin{array}{l}\text { AREA OF A STRESS } \\
\text { CORROSION CRACK } \\
\text { FOR THE EBS } \\
\text { TRANSPORT } \\
\text { ABSTRACTION }\end{array}$ & $\begin{array}{l}\text { ESTIMATE OF THE } \\
\text { MAXIMUM CROSS- } \\
\text { SECTIONAL AREA OF } \\
\text { STRESS CORROSION } \\
\text { CRACKS IN THE OUTER } \\
\text { LID OF A WASTE } \\
\text { PACKAGE }\end{array}$ & D & Q & $\begin{array}{l}\text { Maximum Cross- } \\
\text { Sectional Area Of } \\
\text { Stress Corrosion } \\
\text { Cracks In The } \\
\text { Outer Lid Of A } \\
\text { Waste Package }\end{array}$ & $\begin{array}{l}\text { Material not } \\
\text { related, not } \\
\text { used }\end{array}$ \\
\hline MO0008RIB00082.000 & $\begin{array}{l}\text { ROCK DYNAMIC } \\
\text { PROPERTIES. }\end{array}$ & $\begin{array}{l}\text { RIB ITEM INCLUDES } \\
\text { INFORMATION ON ROCK } \\
\text { DYNAMIC PROPERTIES } \\
\text { INCLUDING ANGLE OF } \\
\text { INCIDENCE OF SEISMIC } \\
\text { WAVE, DYNAMIC SHEAR } \\
\text { STRAIN PROFILE, } \\
\text { PRIMARY AND SHEAR } \\
\text { WAVE VELOCITY IN } \\
\text { ROCK, ROCK MASS } \\
\text { DYNAMIC DEFORMATION. } \\
\text { THESE DATA } \\
\text { SUPERSEDE A PORTION } \\
\text { OF THE DATA } \\
\text { PREVIOUSLY IDENTIFIED } \\
\text { BY DTN: } \\
\text { MO9808RIB00041.000. }\end{array}$ & D & $\mathrm{U}$ & $\begin{array}{l}\text { Summarizes rock } \\
\text { dynamic } \\
\text { properties. } \\
\text { Calculates } \\
\text { dynamic Young's } \\
\text { modulus from } \\
\text { wave velocities. }\end{array}$ & $\begin{array}{l}\text { Repeats or } \\
\text { Summarizes } \\
\text { MO9911SEPG } \\
\text { RP34.000. } \\
\text { ACC: } \\
\text { MOL. } 19991005 \\
.0235, \text { not } \\
\text { used }\end{array}$ \\
\hline MO0104RIB00042.001 & $\begin{array}{l}\text { SOIL } \\
\text { GEOMECHANICAL } \\
\text { PROPERTIES }\end{array}$ & $\begin{array}{l}\text { SOIL GEOENGINEERING } \\
\text { PROPERTIES. THESE } \\
\text { DATA SUPERSEDE DATA } \\
\text { PREVIOUSLY IDENTIFIED } \\
\text { BY DTN: } \\
\text { MO9808RIB00042.000. }\end{array}$ & $D$ & $U$ & $\begin{array}{l}\text { Summary of soil } \\
\text { geomechanical } \\
\text { properties for } \\
\text { waste handling } \\
\text { building and } \\
\text { surface facilities. }\end{array}$ & $\begin{array}{l}\text { Repeats or } \\
\text { summarizes } \\
\text { MOL.19991215 } \\
.0317 \text { and } \\
\text { NNA.19890327 } \\
.0053 ., \text { not } \\
\text { used }\end{array}$ \\
\hline
\end{tabular}


Table 1. DTNs Containing Potentially Relevant Data for Poisson's Ratio and Young's Modulus (Continued)

\begin{tabular}{|c|c|c|c|c|c|c|}
\hline DTN & TITLE & DESCRIPTION & TYPE & $\begin{array}{l}\text { STATUS } \\
\text { (AT } \\
\text { START } \\
\text { OF } \\
\text { REVIEW) } \\
\end{array}$ & COMMENTS & DISPOSITION \\
\hline MO0109RIB00049.001 & $\begin{array}{l}\text { WASTE PACKAGE } \\
\text { MATERIAL } \\
\text { PROPERTIES: } \\
\text { NEUTRON } \\
\text { ABSORBING } \\
\text { MATERIALS }\end{array}$ & $\begin{array}{l}\text { THE OBJECTIVE OF THE } \\
\text { DATA ARE TO COMPILE } \\
\text { AND IDENTIFY THE } \\
\text { APPROPRIATE } \\
\text { MATERIALS THAT WILL } \\
\text { BE USED BY WASTE } \\
\text { PACKAGE OPERATION } \\
\text { AS INPUTS TO DESIGN, } \\
\text { ANALYSIS, } \\
\text { CALCULATIONS, AND } \\
\text { TECHNICAL } \\
\text { DOCUMENTS. THESE } \\
\text { DATA SUPERSEDE DATA } \\
\text { PREVIOUSLY IDENTIFIED } \\
\text { BY DTN: } \\
\text { MO9906RIB00049.000 }\end{array}$ & D & Q & $\begin{array}{l}\text { Waste package } \\
\text { materials data: } \\
\text { Physical } \\
\text { properties of } \\
\text { design materials. } \\
\text { No rock property } \\
\text { data included. }\end{array}$ & $\begin{array}{l}\text { Material not } \\
\text { related, not } \\
\text { used }\end{array}$ \\
\hline MO0111SEPBSWHB.000 & $\begin{array}{l}\text { BOREHOLE } \\
\text { SUSPENSION DATA } \\
\text { FOR WASTE } \\
\text { HANDLING BUILDING } \\
\text { SITE } \\
\text { CHARACTERIZATION } \\
\text { AREA. } \\
\\
\end{array}$ & $\begin{array}{l}\text { SUSPENSION S-WAVE } \\
\text { (SHEAR-WAVE) AND P- } \\
\text { WAVE (COMPRESSION- } \\
\text { WAVE) VELOCITY DATA } \\
\text { FROM BOREHOLES } \\
\text { LOCATED WITHIN THE } \\
\text { WASTE HANDLING } \\
\text { BUILDING SITE } \\
\text { CHARACTERIZATION } \\
\text { AREA. DATA HAS BEEN } \\
\text { SUPERSEDED BY DTN: } \\
\text { MO0204SEPBSWHB.001. }\end{array}$ & A & Q & $\begin{array}{l}\text { Data has been } \\
\text { superseded by } \\
\text { MO0204SEPBS } \\
\text { WHB.001 }\end{array}$ & $\begin{array}{l}\text { Superseded, } \\
\text { not used }\end{array}$ \\
\hline MO0112BSUSPWHB.000 & $\begin{array}{l}\text { BOREHOLE } \\
\text { SUSPENSION DATA } \\
\text { FOR UE-25 RF \#13 } \\
\text { AT THE WASTE } \\
\text { HANDLING BUILDING } \\
\text { SITE } \\
\text { CHARACTERIZATION } \\
\text { AREA. } \\
\\
\\
\end{array}$ & $\begin{array}{l}\text { SUSPENSION S-WAVE } \\
\text { (SHEAR-WAVE) AND P- } \\
\text { WAVE (COMPRESSION- } \\
\text { WAVE) VELOCITY DATA } \\
\text { FROM RF \#13 LOCATED } \\
\text { WITHIN THE WASTE } \\
\text { HANDLING BUILDING } \\
\text { CHARACTERIZATION } \\
\text { AREA. THESE DATA } \\
\text { SUPERSEDES DATA } \\
\text { PREVIOUSLY IDENTIFIED } \\
\text { BY DTN: } \\
\text { MO9903SEISVBDP.000 } \\
\text { AND } \\
\text { MO0001SEPRSSMP.000. } \\
\text { THESE DATA HAVE BEEN } \\
\text { SUPERSEDED BY DTN: } \\
\text { MO0204SEISDWHB.001. }\end{array}$ & A & Q & $\begin{array}{l}\text { Data has been } \\
\text { superseded by } \\
\text { MO0204SEISDW } \\
\text { HB.001 }\end{array}$ & $\begin{array}{l}\text { Superseded, } \\
\text { not used }\end{array}$ \\
\hline MO02045FTDSUSP.001 & \begin{tabular}{|l|} 
STATISTICS FOR \\
SHEAR-WAVE \\
VELOCITY, \\
COMPRESSION- \\
WAVE VELOCITY, \\
AND POISSON'S \\
RATIO BY 1.5 METER \\
DEPTH INTERVALS \\
FROM SUSPENSION \\
SEISMIC \\
MEASUREMENTS
\end{tabular} & $\begin{array}{l}\text { STATISTICS FOR } \\
\text { SUSPENSION SEISMIC } \\
\text { MEASUREMENTS THAT } \\
\text { WERE RECORDED AT } \\
\text { BOREHOLES UE-25 } \\
\text { RF\#13 TO RF\#26, RF\#28 } \\
\text { AND RF\#29. MEAN } \\
\text { VALUES OF SHEAR- } \\
\text { WAVE VELOCITY, } \\
\text { COMPRESSION-WAVE } \\
\text { VELOCITY, AND } \\
\text { POISSON'S RATIO ARE } \\
\text { GIVEN FOR 1.5-METER }\end{array}$ & D & Q & $\begin{array}{l}\text { Poisson's Ratio } \\
\text { and Borehole } \\
\text { Identifier data by } \\
\text { depth interval of } \\
\text { suspension wave } \\
\text { velocity source to } \\
\text { receiver test } \\
\text { results from } \\
\text { boreholes UE-25 } \\
\text { RF \#14 through } \\
\text { UE-25 RF \#26, } \\
\text { UE-25 RF \#28, } \\
\text { and UE-25 RF }\end{array}$ & $\begin{array}{l}\text { Repeats or } \\
\text { Summarizes } \\
\text { MO0204SEPB } \\
\text { SWHB.001, not } \\
\text { used }\end{array}$ \\
\hline
\end{tabular}


Table 1. DTNs Containing Potentially Relevant Data for Poisson's Ratio and Young's Modulus (Continued)

\begin{tabular}{|c|c|c|c|c|c|c|}
\hline DTN & TITLE & DESCRIPTION & TYPE & \begin{tabular}{|} 
STATUS \\
(AT \\
START \\
OF \\
REVIEW)
\end{tabular} & COMMENTS & DISPOSITION \\
\hline & & $\begin{array}{l}\text { INTERVALS OF DEPTH } \\
\text { FOR EACH BOREHOLE. }\end{array}$ & & & $\begin{array}{l}\# 29,10 / 01 / 2000 \\
\text { to } 05 / 01 / 2002 .\end{array}$ & \\
\hline MO0204EBSPYMPG.017 & $\begin{array}{l}\text { PHYSICAL AND } \\
\text { MECHANICAL } \\
\text { PROPERTIES OF } \\
\text { GROUT }\end{array}$ & $\begin{array}{l}\text { DIFFERENT } \\
\text { COMPOSITIONS OF } \\
\text { GROUT WERE TESTED } \\
\text { TO DETERMINE THEIR } \\
\text { PHYSICAL AND } \\
\text { MECHANICAL } \\
\text { PROPERTIES. SPECIFIC } \\
\text { PROPERTIES TESTED } \\
\text { FOR WERE: DENSITY, } \\
\text { VOIDS, COMPRESSIVE } \\
\text { STRENGTH, TENSILE } \\
\text { STRENGTH, ELASTIC } \\
\text { MODULUS, POISSON'S } \\
\text { RATIO, COHESION, AND } \\
\text { ANGLE OF INTERNAL } \\
\text { FRICTION. }\end{array}$ & A & Q & $\begin{array}{l}\text { Physical } \\
\text { properties of } \\
\text { various types of } \\
\text { mixtures of grout }\end{array}$ & $\begin{array}{l}\text { Material not } \\
\text { related, not } \\
\text { used }\end{array}$ \\
\hline MO0204RIB00124.000 & $\begin{array}{l}\text { ROCK DYNAMIC } \\
\text { POISSON'S RATIO }\end{array}$ & $\begin{array}{l}\text { SUMMARY OF EXISTING } \\
\text { DATA ON ROCK DYNAMIC } \\
\text { POISSON'S RATIO BASED } \\
\text { ON THE RESEARCH THAT } \\
\text { HAS BEEN } \\
\text { ACCOMPLISHED BY THE } \\
\text { SUBSURFACE DESIGN } \\
\text { ORGANIZATION. }\end{array}$ & D & $\mathrm{U}$ & $\begin{array}{l}\text { Sources of RIB } \\
\text { Item are } \\
\text { GS94040831223 } \\
2.010, \\
\text { SNL0204068700 } \\
3.001, \\
\text { SNSAND8316460 } \\
\text { 0.000, } \\
\text { SNSAND } 9108940 \\
0.000\end{array}$ & $\begin{array}{l}\text { Repeats or } \\
\text { summarizes, } \\
\text { not used }\end{array}$ \\
\hline MO0204RIB00125.000 & $\begin{array}{l}\text { ROCK DYNAMIC } \\
\text { YOUNG'S MODULUS }\end{array}$ & $\begin{array}{l}\text { SUMMARY OF EXISTING } \\
\text { DATA ON ROCK DYNAMIC } \\
\text { YOUNG'S MODULUS } \\
\text { BASED ON THE } \\
\text { RESEARCH THAT HAS } \\
\text { BEEN ACCOMPLISHED } \\
\text { BY THE SUBSURFACE } \\
\text { DESIGN ORGANIZATION. }\end{array}$ & D & U & $\begin{array}{l}\text { Summary Of } \\
\text { Existing Data On } \\
\text { Intact Rock } \\
\text { Young's Modulus }\end{array}$ & $\begin{array}{l}\text { Repeats or } \\
\text { summarizes } \\
\text { GS940408312 } \\
\text { 232.010, } \\
\text { SNSAND9108 } \\
9400.000, \\
\text { SNL02040687 } \\
\text { 003.001, and } \\
\text { SNSAND8316 } \\
4600.000, \text { not } \\
\text { used }\end{array}$ \\
\hline MO0204RIB00126.000 & $\begin{array}{l}\text { INTACT ROCK } \\
\text { POISSON'S RATIO }\end{array}$ & $\begin{array}{l}\text { SUMMARY OF EXISTING } \\
\text { DATA ON INTACT ROCK } \\
\text { POISSON'S RATIO BASED } \\
\text { ON THE RESEARCH THAT } \\
\text { HAS BEEN } \\
\text { ACCOMPLISHED BY THE } \\
\text { SUBSURFACE DESIGN } \\
\text { ORGANIZATION. }\end{array}$ & D & U & $\begin{array}{l}\text { SUMMARY OF } \\
\text { EXISTING DATA } \\
\text { ON INTACT } \\
\text { ROCK } \\
\text { POISSON'S } \\
\text { RATIO. }\end{array}$ & $\begin{array}{l}\text { Repeats or } \\
\text { Summarizes, } \\
\text { not used }\end{array}$ \\
\hline
\end{tabular}


Table 1. DTNs Containing Potentially Relevant Data for Poisson's Ratio and Young's Modulus (Continued)

\begin{tabular}{|c|c|c|c|c|c|c|}
\hline DTN & TITLE & DESCRIPTION & TYPE & $\begin{array}{l}\text { STATUS } \\
\text { (AT } \\
\text { START } \\
\text { OF } \\
\text { REVIEW) }\end{array}$ & COMMENTS & DISPOSITION \\
\hline MO0204RIB00127.000 & $\begin{array}{l}\text { INTACT ROCK } \\
\text { YOUNG'S MODULUS }\end{array}$ & $\begin{array}{l}\text { SUMMARY OF EXISTING } \\
\text { DATA ON INTACT ROCK } \\
\text { YOUNG'S MODULUS } \\
\text { BASED ON THE } \\
\text { RESEARCH THAT HAS } \\
\text { BEEN ACCOMPLISHED } \\
\text { BY THE SUBSURFACE } \\
\text { DESIGN ORGANIZATION. }\end{array}$ & $\mathrm{D}$ & $\mathrm{U}$ & $\begin{array}{l}\text { SUMMARY OF } \\
\text { EXISTING DATA } \\
\text { ON INTACT } \\
\text { ROCK YOUNG'S } \\
\text { MODULUS }\end{array}$ & $\begin{array}{l}\text { Repeats or } \\
\text { Summarizes } \\
\text { (See list of } \\
\text { references) } \\
\text { not used }\end{array}$ \\
\hline MO0204RIB00129.000 & $\begin{array}{l}\text { IN SITU ROCK } \\
\text { YOUNG'S MODULUS }\end{array}$ & $\begin{array}{l}\text { SUMMARY OF EXISTING } \\
\text { DATA ON IN SITU ROCK } \\
\text { YOUNG'S MODULUS } \\
\text { BASED ON THE } \\
\text { RESEARCH THAT HAS } \\
\text { BEEN ACCOMPLISHED } \\
\text { BY THE SUBSURFACE } \\
\text { DESIGN ORGANIZATION. }\end{array}$ & D & Q & $\begin{array}{l}\text { SUMMARY OF } \\
\text { EXISTING DATA } \\
\text { ON IN SITU } \\
\text { ROCK YOUNG'S } \\
\text { MODULUS }\end{array}$ & $\begin{array}{l}\text { Repeats or } \\
\text { summarizes } \\
\text { SN0011F3912 } \\
298.023 \text { and } \\
\text { SNF39012298 } \\
\text { 001.002, not } \\
\text { used }\end{array}$ \\
\hline MO0204SEPBSWHB.001 & $\begin{array}{l}\text { BOREHOLE } \\
\text { SUSPENSION DATA } \\
\text { FOR WASTE } \\
\text { HANDLING BUILDING } \\
\text { SITE } \\
\text { CHARACTERIZATION } \\
\text { AREA } \\
\\
\end{array}$ & $\begin{array}{l}\text { SUSPENSION S-WAVE } \\
\text { (SHEAR-WAVE) AND P- } \\
\text { WAVE (COMPRESSION- } \\
\text { WAVE) ARRIVAL TIME } \\
\text { AND VELOCITY DATA } \\
\text { FROM BOREHOLES } \\
\text { LOCATED WITHIN THE } \\
\text { WASTE HANDLING } \\
\text { BUILDING SITE } \\
\text { CHARACTERIZATION } \\
\text { AREA. THESE DATA } \\
\text { SUPESEDE DATA } \\
\text { PREVIOUSLY IDENTIFIED } \\
\text { BY DTN: } \\
\text { MO0111SEPBSWHB.000. }\end{array}$ & A & Q & $\begin{array}{l}\text { Seismic S-Wave } \\
\text { Velocity, Seismic } \\
\text { P-Wave Velocity, } \\
\text { and Poisson's } \\
\text { Ratio data based } \\
\text { on receiver-to- } \\
\text { receiver travel } \\
\text { time data at } \\
\text { boreholes UE-25 } \\
\text { RF \#14 through \# } \\
26, \text { and \#28 and } \\
\# 29,07 / 06 / 2000 \\
\text { to } 10 / 18 / 2001 .\end{array}$ & Directly Used \\
\hline
\end{tabular}


Table 1. DTNs Containing Potentially Relevant Data for Poisson's Ratio and Young's Modulus (Continued)

\begin{tabular}{|c|c|c|c|c|c|c|}
\hline DTN & TITLE & DESCRIPTION & TYPE & $\begin{array}{l}\text { STATUS } \\
\text { (AT } \\
\text { START } \\
\text { OF } \\
\text { REVIEW) }\end{array}$ & COMMENTS & DISPOSITION \\
\hline MO0204SEPFDSSS.000 & $\begin{array}{l}\text { PROFILES OF } \\
\text { AVERAGE SHEAR- } \\
\text { WAVE VELOCITY, } \\
\text { COMPRESSION- } \\
\text { WAVE VELOCITY } \\
\text { AND POISSON'S } \\
\text { RATIO FROM } \\
\text { ACCUMULATED } \\
\text { TRAVEL TIMES } \\
\text { FROM SUSPENSION } \\
\text { SEISMIC SURVEYS } \\
\text { AT BOREHOLES UE- } \\
\text { 25 RF\#14 TO \#26 } \\
\text { AND RF\#28 AND } \\
\text { RF\#29. }\end{array}$ & $\begin{array}{l}\text { SHEAR-WAVE TRAVEL } \\
\text { TIMES FROM } \\
\text { SUSPENSION SEISMIC } \\
\text { SOURCE-TO-RECEIVER } \\
\text { MEASUREMENTS WERE } \\
\text { ACCUMULATED WITH } \\
\text { DEPTH AND PLOTTED AS } \\
\text { TRAVEL TIME VERSUS } \\
\text { DEPTH. STRAIGHT LINES } \\
\text { WERE FIT TO THE } \\
\text { ORDERED PAIRS BY } \\
\text { LINEAR REGRESSION. } \\
\text { THE SLOPES OF THE } \\
\text { REGRESSION LINES ARE } \\
\text { SHEAR-WAVE } \\
\text { VELOCITIES. THE SAME } \\
\text { PROCEDURE WAS } \\
\text { FOLLOWED FOR SHEAR- } \\
\text { WAVE TRAVEL TIMES } \\
\text { FROM SUSPENSION } \\
\text { SEISMIC RECEIVER-TO- } \\
\text { RECEIVER } \\
\text { MEASUREMENTS AND } \\
\text { COMPRESSION-WAVE } \\
\text { TRAVEL TIMES FROM } \\
\text { SUSPENSION SEISMIC } \\
\text { SOURCE-TO-RECEIVER } \\
\text { MEASUREMENTS. } \\
\end{array}$ & D & Q & $\begin{array}{l}\text { Poisson's Ratio } \\
\text { data from } \\
\text { accumulated } \\
\text { travel times from } \\
\text { source-to-receiver } \\
\text { suspension test } \\
\text { results vs depth } \\
\text { at boreholes UE- } \\
25 \text { RF \#14 } \\
\text { through \# 26, and } \\
\# 28 \text { and \#29, } \\
08 / 31 / 2000 \text { to } \\
04 / 18 / 2002 \text {. }\end{array}$ & $\begin{array}{l}\text { Repeats or } \\
\text { summarizes } \\
\text { data from } \\
\text { MO0204SEPB } \\
\text { SWHB.001, not } \\
\text { used }\end{array}$ \\
\hline MO0204SUSPSEIS.001 & $\begin{array}{l}\text { STATISTICS FOR } \\
\text { SHEAR-WAVE } \\
\text { VELOCITY, } \\
\text { COMPRESSION- } \\
\text { WAVE VELOCITY, } \\
\text { AND POISSON'S } \\
\text { RATIO BY } \\
\text { LITHOSTRATIGRAPH } \\
\text { IC UNIT FROM } \\
\text { SUSPENSION } \\
\text { SEISMIC } \\
\text { MEASUREMENTS }\end{array}$ & $\begin{array}{l}\text { STATISTICS FOR } \\
\text { SUSPENSION SEISMIC } \\
\text { MEASUREMENTS THAT } \\
\text { WERE RECORDED AT } \\
\text { BOREHOLES UE-25 } \\
\text { RF\#13 TO RF\#26, RF\#28 } \\
\text { AND RF\#29. MEAN, } \\
\text { MEDIAN, STANDARD } \\
\text { DEVIATION, } \\
\text { COEFFICIENT OF } \\
\text { VARIATION AND COUNT } \\
\text { ARE GIVEN FOR SHEAR- } \\
\text { WAVE VELOCITY, } \\
\text { COMPRESSION-WAVE } \\
\text { VELOCITY, AND } \\
\text { POISSON'S RATIO BY } \\
\text { LITHOSTRATIGRAPHIC } \\
\text { UNIT FOR EACH } \\
\text { BOREHOLE AND FOR } \\
\text { THE ENTIRE GROUP OF } \\
\text { BOREHOLES TAKEN } \\
\text { TOGETHER. }\end{array}$ & D & Q & $\begin{array}{l}\text { Poisson's Ratio } \\
\text { and Borehole } \\
\text { Identifier data by } \\
\text { lithostratigraphic } \\
\text { units from source } \\
\text { to receiver } \\
\text { suspension } \\
\text { seismic } \\
\text { measurements } \\
\text { from boreholes } \\
\text { UE-25 RF \#13 } \\
\text { through UE-25 } \\
\text { RF \#26, UE-25 } \\
\text { RF \#28, and UE- } \\
25 \text { RF \#29, } \\
10 / 01 / 2001 \text { to } \\
05 / 10 / 2002 \text {. }\end{array}$ & $\begin{array}{l}\text { Repeats or } \\
\text { summarizes } \\
\text { data from } \\
\text { MO0204SEPB } \\
\text { SWHB.001, not } \\
\text { used }\end{array}$ \\
\hline
\end{tabular}


Table 1. DTNs Containing Potentially Relevant Data for Poisson's Ratio and Young's Modulus (Continued)

\begin{tabular}{|c|c|c|c|c|c|c|}
\hline DTN & TITLE & DESCRIPTION & TYPE & $\begin{array}{l}\text { STATUS } \\
\text { (AT } \\
\text { START } \\
\text { OF } \\
\text { REVIEW) } \\
\end{array}$ & COMMENTS & DISPOSITION \\
\hline MO0205SEPPRDSV.000 & $\begin{array}{l}\text { PROFILES OF } \\
\text { POISSON'S RATIO } \\
\text { FROM DOWNHOLE } \\
\text { SEISMIC VELOCITY } \\
\text { PROFILES AT } \\
\text { BOREHOLES UE-25 } \\
\text { RF\#13 TO \#26 AND } \\
\text { RF\#28 AND RF\#29. }\end{array}$ & $\begin{array}{l}\text { THE SHEAR-WAVE } \\
\text { VELOCITY AND } \\
\text { COMPRESSION-WAVE } \\
\text { VELOCITY PROFILES } \\
\text { INTERPRETED AT } \\
\text { BOREHOLES UE-25 } \\
\text { RF\#13 TO RF\#26 AND } \\
\text { RF\#28 AND RF\#29 WERE } \\
\text { USED TO COMPUTE } \\
\text { POISSON'S RATIO. }\end{array}$ & D & Q & $\begin{array}{l}\text { Poisson's Ratio } \\
\text { data from } \\
\text { downhole seismic } \\
\text { velocity profiles at } \\
\text { boreholes UE-25 } \\
\text { RF \#13 to UE-25 } \\
\text { RF \#26, UE-25 } \\
\text { RF \#28, and UE- } \\
25 \text { RF \#29, } \\
11 / 30 / 2001 \text { to } \\
12 / 14 / 2001 .\end{array}$ & $\begin{array}{l}\text { Repeats or } \\
\text { summarizes } \\
\text { data from } \\
\text { MO0204SEPB } \\
\text { SWHB.001, not } \\
\text { used }\end{array}$ \\
\hline MO9008RIB00012.003 & $\begin{array}{l}\text { RIB ITEM\#12/REV3: } \\
\text { GEOLOGIC } \\
\text { CHARACTERISTICS: } \\
\text { STATIC ROCK } \\
\text { MECHANICAL } \\
\text { PROPERTIES. }\end{array}$ & $\begin{array}{l}\text { THIS RIB ITEM IS } \\
\text { SUPERSEDED BY } \\
\text { MO9808RIB00041.000. }\end{array}$ & D & $\mathrm{U}$ & $\begin{array}{l}\text { RIB Item } \\
\text { superseded by } \\
\text { one written by M. } \\
\text { Nash on rock } \\
\text { geomechanical } \\
\text { properties }\end{array}$ & $\begin{array}{l}\text { Superseded by } \\
\text { MO9808RIB00 } \\
\text { 041.000, not } \\
\text { used }\end{array}$ \\
\hline MO9212RIB00005.003 & $\begin{array}{l}\text { RIB ITEM\#5/REV3: } \\
\text { GEOLOGIC } \\
\text { CHARACTERISTICS: } \\
\text { DYNAMIC SOIL } \\
\text { MECHANICAL } \\
\text { PROPERTIES. } \\
\end{array}$ & $\begin{array}{l}\text { THESE DATA ARE } \\
\text { SUPERSEDED BY DATA } \\
\text { IDENTIFIED BY DTN } \\
\text { NO9808RIB00042.000. }\end{array}$ & $\mathrm{D}$ & $\mathrm{U}$ & $\begin{array}{l}\text { RIB Item } \\
\text { superseded by } \\
\text { one written by M. } \\
\text { Nash on soil } \\
\text { geomechanical } \\
\text { properties }\end{array}$ & $\begin{array}{l}\text { Superceded by } \\
\text { MO9808RIB00 } \\
\text { 042.000, not } \\
\text { used }\end{array}$ \\
\hline MO9808RIB00041.000 & $\begin{array}{l}\text { REFERENCE } \\
\text { INFORMATION BASE } \\
\text { DATA ITEM: ROCK } \\
\text { GEOMECHANICAL } \\
\text { PROPERTIES. }\end{array}$ & \begin{tabular}{|l|} 
THIS RIB ITEM \\
SUPERSEDES: \\
MO9008RIB00013.003, \\
MO8902RIB00016.003, \\
MO8902RIB00009.003, \\
MO9008RIB00012.003. \\
THESE DATA HAVE BEEN \\
PARTIALLY SUPERSEDED \\
BY DATA IDENTIFIED \\
WITH DTN: \\
MO0008RIB00082.000, \\
MO0003RIB00079.000. \\
\end{tabular} & A & Q & $\begin{array}{l}\text { RIB Item written } \\
\text { by M. Nash on } \\
\text { rock } \\
\text { geomechanical } \\
\text { properties }\end{array}$ & $\begin{array}{l}\text { Repeats or } \\
\text { summarizes } \\
\text { developed data } \\
\text { in } \\
\text { MOL.19959126 } \\
.0004, \text { not used }\end{array}$ \\
\hline MO9808RIB00042.000 & $\begin{array}{l}\text { REFERENCE } \\
\text { INFORMATION BASE } \\
\text { DATA ITEM: - } \\
\text { GEOLOGIC } \\
\text { CHARACTERISTICS: } \\
\text { SOIL } \\
\text { GEOMECHANICAL } \\
\text { PROPERTIES. }\end{array}$ & \begin{tabular}{|l|} 
THIS RIB ITEM \\
SUPERSEDES: \\
MO9212RIB00008.003, \\
MO9212RIB00007.003, \\
MO9212RIB00005.003, \\
MO9212RIB00006.003, \\
MO9212RIB00004.003. \\
THESE DATA HAVE BEEN \\
SUPERSEDED BY DATA \\
IDENTIFIED WITH DTN: \\
MO0104RIB00042.001 \\
\end{tabular} & D & Q & $\begin{array}{l}\text { RIB Item } \\
\text { superseded by } \\
\text { one written by M. } \\
\text { Nash on soil } \\
\text { geomechanical } \\
\text { properties }\end{array}$ & $\begin{array}{l}\text { Superseded by } \\
\text { MO0104RIB00 } \\
\text { 042.001, not } \\
\text { used }\end{array}$ \\
\hline MO9906RIB00048.000 & $\begin{array}{l}\text { WASTE PACKAGE } \\
\text { MATERIAL } \\
\text { PROPERTIES: } \\
\text { WASTE FORM } \\
\text { MATERIALS. }\end{array}$ & $\begin{array}{l}\text { THE OBJECTIVE OF THE } \\
\text { DATA ARE TO COMPILE } \\
\text { AND IDENTIFY THE } \\
\text { APPROPRIATE } \\
\text { MATERIALS THAT WILL } \\
\text { BE USED BY WASTE } \\
\text { PACKAGE OPERATION } \\
\text { AS INPUTS TO DESIGN, } \\
\text { ANALYSIS, } \\
\text { CALCULATIONS, AND } \\
\text { TECHNICAL DOCUMENTS }\end{array}$ & D & Q & $\begin{array}{l}\text { Waste package } \\
\text { materials data: } \\
\text { Physical } \\
\text { properties of } \\
\text { design materials. } \\
\text { No rock property } \\
\text { data included. }\end{array}$ & $\begin{array}{l}\text { Material not } \\
\text { related, not } \\
\text { used }\end{array}$ \\
\hline
\end{tabular}


Table 1. DTNs Containing Potentially Relevant Data for Poisson's Ratio and Young's Modulus (Continued)

\begin{tabular}{|c|c|c|c|c|c|c|}
\hline DTN & TITLE & DESCRIPTION & TYPE & $\begin{array}{l}\text { STATUS } \\
\text { (AT } \\
\text { START } \\
\text { OF } \\
\text { REVIEW) } \\
\end{array}$ & COMMENTS & DISPOSITION \\
\hline MO9906RIB00049.000 & $\begin{array}{l}\text { WASTE PACKAGE } \\
\text { MATERIAL } \\
\text { PROPERTIES: } \\
\text { NEUTRON } \\
\text { ABSORBING } \\
\text { MATERIALS. }\end{array}$ & $\begin{array}{l}\text { THE OBJECTIVE OF THE } \\
\text { DATA ARE TO COMPILE } \\
\text { AND IDENTIFY THE } \\
\text { APPROPRIATE } \\
\text { MATERIALS THAT WILL } \\
\text { BE USED BY WASTE } \\
\text { PACKAGE OPERATION } \\
\text { AS INPUTS TO DESIGN, } \\
\text { ANALYSIS, } \\
\text { CALCULATIONS, AND } \\
\text { TECHNICAL } \\
\text { DOCUMENTS. DATA } \\
\text { HAVE BEEN } \\
\text { SUPERSEDED BY DATA } \\
\text { IDENTIFIED WITH DTN: } \\
\text { MO0109RIB00049.001. } \\
\end{array}$ & D & Q & $\begin{array}{l}\text { Superseded by } \\
\text { RIB Item written } \\
\text { by M. Nash }\end{array}$ & $\begin{array}{l}\text { Material not } \\
\text { related, not } \\
\text { used }\end{array}$ \\
\hline MO9906RIB00050.000 & $\begin{array}{l}\text { WASTE PACKAGE } \\
\text { MATERIAL } \\
\text { PROPERTIES: } \\
\text { CERAMIC COATING } \\
\text { MATERIALS. }\end{array}$ & $\begin{array}{l}\text { THE OBJECTIVE OF THE } \\
\text { DATA ARE TO COMPILE } \\
\text { AND IDENTIFY THE } \\
\text { APPROPRIATE } \\
\text { MATERIALS THAT WILL } \\
\text { BE USED BY WASTE } \\
\text { PACKAGE OPERATION } \\
\text { AS INPUTS TO DESIGN, } \\
\text { ANALYSIS, } \\
\text { CALCULATIONS, AND } \\
\text { TECHNICAL DOCUMENTS }\end{array}$ & D & Q & $\begin{array}{l}\text { Waste package } \\
\text { materials data: } \\
\text { Physical } \\
\text { properties of } \\
\text { design materials. } \\
\text { No rock property } \\
\text { data included. }\end{array}$ & $\begin{array}{l}\text { Material not } \\
\text { related, not } \\
\text { used }\end{array}$ \\
\hline MO9906RIB00052.000 & $\begin{array}{l}\text { WASTE PACKAGE } \\
\text { MATERIAL } \\
\text { PROPERTIES: } \\
\text { CORROSION } \\
\text { RESISTANT } \\
\text { MATERIALS. }\end{array}$ & $\begin{array}{l}\text { THE OBJECTIVE OF THE } \\
\text { DATA ARE TO COMPILE } \\
\text { AND IDENTIFY THE } \\
\text { APPROPRIATES } \\
\text { MATERIALS THAT WILL } \\
\text { BE USED BY WASTE } \\
\text { PACKAGE OPERATION } \\
\text { AS INPUTS TO DESIGN, } \\
\text { ANALYSIS, } \\
\text { CALCULATIONS, AND } \\
\text { TECHNICAL } \\
\text { DOCUMENTS. THESE } \\
\text { DATA SUPERSEDE DATA } \\
\text { PREVIOUSLY IDENTIFIED } \\
\text { BY DTN(S): } \\
\text { LL9708RIB0031A.001, } \\
\text { LL9503RIB0032A.000, AND } \\
\text { LL9503RIB0034A.000. ALL } \\
\text { ALLOY 22 DATA FOUND } \\
\text { IN THIS DTN HAVE BEEN } \\
\text { SUPERSEDED BY DATA } \\
\text { IDENTIFIED WITH DTN: } \\
\text { MO0003RIB00071.000. } \\
\text { ALL TITANIUM GRADES } 7 \\
\text { AND 16 DATA FOUND IN } \\
\text { THIS DTN HAVE BEEN } \\
\text { SUPERSEDED BY DATA } \\
\text { IDENTIFIED WITH DTN: } \\
\text { MO0003RIB00073.000. } \\
\end{array}$ & D & Q & $\begin{array}{l}\text { Waste package } \\
\text { materials data: } \\
\text { Physical } \\
\text { properties of } \\
\text { design materials. } \\
\text { No rock property } \\
\text { data included. }\end{array}$ & $\begin{array}{l}\text { Material not } \\
\text { related, not } \\
\text { used }\end{array}$ \\
\hline
\end{tabular}


Table 1. DTNs Containing Potentially Relevant Data for Poisson's Ratio and Young's Modulus (Continued)

\begin{tabular}{|c|c|c|c|c|c|c|}
\hline DTN & TITLE & DESCRIPTION & TYPE & $\begin{array}{l}\text { STATUS } \\
\text { (AT } \\
\text { START } \\
\text { OF } \\
\text { REVIEW) } \\
\end{array}$ & COMMENTS & DISPOSITION \\
\hline MO9906RIB00053.000 & $\begin{array}{l}\text { WASTE PACKAGE } \\
\text { MATERIAL } \\
\text { PROPERTIES: } \\
\text { CORROSION } \\
\text { ALLOWANCE AND } \\
\text { BASKET MATERIALS. }\end{array}$ & $\begin{array}{l}\text { THE OBJECTIVE OF THE } \\
\text { DATA ARE TO COMPILE } \\
\text { AND IDENTIFY THE } \\
\text { APPROPRIATES } \\
\text { MATERIALS THAT WILL } \\
\text { BE USED BY WASTE } \\
\text { PACKAGE OPERATION } \\
\text { AS INPUTS TO DESIGN, } \\
\text { ANALYSIS, } \\
\text { CALCULATIONS, AND } \\
\text { TECHNICAL } \\
\text { DOCUMENTS. THESE } \\
\text { DATA SUPERSEDE DATA } \\
\text { PREVIOUSLY IDENTIFIED } \\
\text { BY DTN(S): } \\
\text { LL9708RIB0031A.001, } \\
\text { LL9503RIB0032A.000, AND } \\
\text { LL9503RIB0034A.000. ALL } \\
\text { ALLOY 516 DATA IN THIS } \\
\text { DTN HAVE BEEN } \\
\text { SUPERSEDED BY DATA } \\
\text { IDENTIFIED WITH DTN: } \\
\text { MO0003RIB00072.000. } \\
\end{array}$ & D & Q & $\begin{array}{l}\text { Waste package } \\
\text { materials data: } \\
\text { Physical } \\
\text { properties of } \\
\text { design materials. } \\
\text { No rock property } \\
\text { data included. }\end{array}$ & $\begin{array}{l}\text { Material not } \\
\text { related, not } \\
\text { used }\end{array}$ \\
\hline MO9906RIB00054.000 & $\begin{array}{l}\text { WASTE PACKAGE } \\
\text { MATERIAL } \\
\text { PROPERTIES: } \\
\text { STRUCTURAL } \\
\text { MATERIALS. }\end{array}$ & $\begin{array}{l}\text { THE OBJECTIVE OF THE } \\
\text { DATA ARE TO COMPILE } \\
\text { AND IDENTIFY THE } \\
\text { APPROPRIATES } \\
\text { MATERIALS THAT WILL } \\
\text { BE USED BY WASTE } \\
\text { PACKAGE OPERATION } \\
\text { AS INPUTS TO DESIGN, } \\
\text { ANALYSIS, } \\
\text { CALCULATIONS, AND } \\
\text { TECHNICAL } \\
\text { DOCUMENTS. ALL ALLOY } \\
\text { 316N DATA FOUND IN } \\
\text { THIS DTN HAVE BEEN } \\
\text { SUPERSEDED BY DATA } \\
\text { IDENTIFIED WITH DTN: } \\
\text { MO0003RIB00076.000. } \\
\end{array}$ & D & Q & $\begin{array}{l}\text { Waste package } \\
\text { materials data: } \\
\text { Physical } \\
\text { properties of } \\
\text { design materials. } \\
\text { No rock property } \\
\text { data included. }\end{array}$ & $\begin{array}{l}\text { Material not } \\
\text { related, not } \\
\text { used }\end{array}$ \\
\hline MO9911SEPGRP34.000 & $\begin{array}{l}\text { GEOTECHNICAL } \\
\text { ROCK PROPERTIES }\end{array}$ & $\begin{array}{l}\text { GEOTECHNICAL ROCK } \\
\text { PROPERTIES FOR USE IN } \\
\text { SUBSURFACE DESIGN }\end{array}$ & D & Q & $\begin{array}{l}\text { Rock mass } \\
\text { Poisson's ratio } \\
\text { mean and std dev } \\
\text { by themal mech } \\
\text { unit and rock } \\
\text { mass quality } \\
\text { category used by } \\
\text { subsurface } \\
\text { design }\end{array}$ & $\begin{array}{l}\text { Repeats or } \\
\text { summarizes } \\
\text { values taken } \\
\text { from other } \\
\text { sources that } \\
\text { were } \\
\text { evaluated, not } \\
\text { used }\end{array}$ \\
\hline
\end{tabular}


Table 1. DTNs Containing Potentially Relevant Data for Poisson's Ratio and Young's Modulus (Continued)

\begin{tabular}{|c|c|c|c|c|c|c|}
\hline DTN & TITLE & DESCRIPTION & TYPE & $\begin{array}{l}\text { STATUS } \\
\text { (AT } \\
\text { START } \\
\text { OF } \\
\text { REVIEW) } \\
\end{array}$ & COMMENTS & DISPOSITION \\
\hline MO9912SPABAS00.001 & $\begin{array}{l}\text { BASIC PROPERTIES } \\
\text { OF SEVERAL } \\
\text { METALS FROM } \\
\text { "STANDARD } \\
\text { HANDBOOK FOR } \\
\text { MECHANICAL } \\
\text { ENGINEERS, 7TH } \\
\text { EDITION" }\end{array}$ & $\begin{array}{l}\text { TWO NUMBERS ARE } \\
\text { USED FROM THIS TABLE. } \\
\text { 1-COEFFICIENT OF } \\
\text { THERMAL EXPANSION } \\
\text { AND 2-MODULUS OF } \\
\text { ELASTICITY FOR } \\
\text { TITANIUM B 120VCA } \\
\text { (AGED) FROM PAGE 6-10, } \\
\text { THESE DATA HAVE BEEN } \\
\text { SUPERSEDED BY DATA } \\
\text { IDENTIFIED WITH DTN: } \\
\text { MO0003SPABPS00.002. }\end{array}$ & $A$ & $\mathrm{U}$ & $\begin{array}{l}\text { Properties of } \\
\text { metals from } \\
\text { engineering } \\
\text { handbook }\end{array}$ & $\begin{array}{l}\text { Material not } \\
\text { related, not } \\
\text { used }\end{array}$ \\
\hline SN0011F3912298.023 & $\begin{array}{l}\text { PLATE-LOADING } \\
\text { ROCK MASS } \\
\text { MODULUS DATA } \\
\text { (WITH RESULTS } \\
\text { FROM 10/16/2000 } \\
\text { THROUGH } \\
10 / 17 / 2000) \\
\end{array}$ & $\begin{array}{l}\text { ROCK MASS MODULUS } \\
\text { DATA FOR THE PLATE- } \\
\text { LOADING TEST. THESE } \\
\text { DATA SUPPORT SITE } \\
\text { RECOMMENDATION. }\end{array}$ & D & Q & $\begin{array}{l}\text { Young's data } \\
\text { obtained from the } \\
\text { plate loading test } \\
\text { collected near the } \\
\text { heated drift, ESF }\end{array}$ & $\begin{array}{l}\text { Not Directly } \\
\text { Related (In Situ } \\
\text { measurements } \\
\text { which differ } \\
\text { from Intact } \\
\text { Measurements } \\
\text {, , not used }\end{array}$ \\
\hline SN0108SD821723.001 & $\begin{array}{l}\text { UNIAXIAL AND } \\
\text { TRIAXIAL } \\
\text { COMPRESSION } \\
\text { TEST DATA ON } \\
\text { SAMPLES FROM } \\
\text { USW G-1 (VA } \\
\text { SUPPORTING DATA) }\end{array}$ & $\begin{array}{l}\text { DEVELOPED DATA FROM } \\
\text { SAND82-1723 FOR } \\
\text { UNIAXIAL AND TRIAXIAL } \\
\text { COMPRESSION TEST } \\
\text { SERIES ON TOPOPAH } \\
\text { SPRING TUFF. THESE } \\
\text { DATA SUPERSEDE DATA } \\
\text { PREVIOUSLY IDENTIFIED } \\
\text { BY DTN: } \\
\text { SNSAND82172300.000. }\end{array}$ & D & $\mathrm{U}$ & $\begin{array}{l}\text { Compressive } \\
\text { Strength, Young's } \\
\text { Modulus, and } \\
\text { Poisson's Ratio } \\
\text { data of } \\
\text { rock samples } \\
\text { from the Topopah } \\
\text { Spring Member of } \\
\text { USW G-1 }\end{array}$ & $\begin{array}{l}\text { Corroborating, } \\
\text { carried forward } \\
\text { for evaluation }\end{array}$ \\
\hline SNF35110695001.002 & $\begin{array}{l}\text { PRE-EXPERIMENT } \\
\text { THERMAL- } \\
\text { HYDROLOGICAL- } \\
\text { MECHANICAL } \\
\text { ANALYSES FOR THE } \\
\text { ESF SINGLE HEATER } \\
\text { TEST - PHASE } 2 . \\
\end{array}$ & $\begin{array}{l}\text { SANDIA LETTER REPORT, } \\
\text { SLTR96-0005. }\end{array}$ & D & Q & $\begin{array}{l}\text { Presents values } \\
\text { of Poisson of } \\
0.165 \text { and } Y \text { of } \\
32.4 \text { from } \\
\text { SNL2208019600 } \\
1.002\end{array}$ & $\begin{array}{l}\text { Repeats or } \\
\text { Summarizes } \\
\text { average values } \\
\text { from } \\
\text { SNL22080196 } \\
\text { 001.002, not } \\
\text { used }\end{array}$ \\
\hline SNF35110695002.001 & $\begin{array}{l}\text { PRE-EXPERIMENT } \\
\text { THERMAL- } \\
\text { HYDROLOGICAL- } \\
\text { MECHANICAL } \\
\text { ANALYSES FOR THE } \\
\text { ESF HEATED DRIFT } \\
\text { TEST. }\end{array}$ & $\begin{array}{l}\text { SANDIA LETTER REPORT, } \\
\text { SLTR97-0002. }\end{array}$ & D & Q & $\begin{array}{l}\text { Derived values of } \\
\text { Young's modulus } \\
\text { for rock mass } \\
\text { based on RMR } \\
\text { values. Poisson } \\
\text { ratio based on } \\
\text { SNL0210019600 } \\
1.001 \text { (intact rock } \\
\text { data from heated } \\
\text { drift samples) }\end{array}$ & $\begin{array}{l}\text { Repeats or } \\
\text { summarizes } \\
\text { SNL02100196 } \\
\text { 001.001, not } \\
\text { used }\end{array}$ \\
\hline SNF39012298001.002 & $\begin{array}{l}\text { PLATE-LOADING } \\
\text { ROCK MASS } \\
\text { MODULUS DATA. }\end{array}$ & $\begin{array}{l}\text { PLATE-LOADING ROCK } \\
\text { MASS MODULUS DATA. }\end{array}$ & D & Q & $\begin{array}{l}\text { Modulus of } \\
\text { Deformation data } \\
\text { (Plate Loading } \\
\text { Rock Mass } \\
\text { Modulus data) } \\
\text { from Borehole } \\
\# 187 \text { and \#188 }\end{array}$ & $\begin{array}{l}\text { Material not } \\
\text { related, not } \\
\text { used }\end{array}$ \\
\hline
\end{tabular}


Table 1. DTNs Containing Potentially Relevant Data for Poisson's Ratio and Young's Modulus (Continued)

\begin{tabular}{|c|c|c|c|c|c|c|}
\hline DTN & TITLE & DESCRIPTION & TYPE & $\begin{array}{l}\text { STATUS } \\
\text { (AT } \\
\text { START } \\
\text { OF } \\
\text { REVIEW) }\end{array}$ & COMMENTS & DISPOSITION \\
\hline SNL01B05059301.001 & $\begin{array}{l}\text { THERMAL } \\
\text { EXPANSION DATA } \\
\text { FOR DRILLHOLE } \\
\text { NRG-6, SAMPLES } \\
\text { FROM DEPTH } 28.8 \\
\text { TO 416.0 FEET, } \\
\text { AMBIENT TO } 100 \\
\text { DEG. C. }\end{array}$ & $\begin{array}{l}\text { MEAN COEFFICIENTS OF } \\
\text { THERMAL EXPANSION } \\
\text { (CTE'S), MINIMUM AND } \\
\text { MAXIMUM } \\
\text { INSTANTANEOUS CTE, } \\
\text { SAMPLE DIMENSIONS, } \\
\text { SAMPLE VOLUME, PRE- } \\
\text { AND POST-TEST SAMPLE } \\
\text { MASSES. }\end{array}$ & A & Q & $\begin{array}{l}\text { Thermal } \\
\text { Expansion data } \\
\text { for borehole } \\
\text { NRG-6. }\end{array}$ & $\begin{array}{l}\text { Material not } \\
\text { related, not } \\
\text { used }\end{array}$ \\
\hline SNL01B05059301.002 & $\begin{array}{l}\text { THERMAL } \\
\text { EXPANSION DATA } \\
\text { FROM USW NRG-6 } \\
\text { DRILLHOLE FROM } \\
\text { DEPTH OF 28.8 FT. } \\
\text { TO 416.0 FT. }\end{array}$ & $\begin{array}{l}\text { THIS DATA HAS BEEN } \\
\text { SUPERSEDED BY DATA } \\
\text { IDENTIFIED BY DTN: } \\
\text { SNL01B05059301.003. }\end{array}$ & $A$ & Q & $\begin{array}{l}\text { DATA HAS BEEN } \\
\text { SUPERSEDED } \\
\text { BY DATA } \\
\text { IDENTIFIED BY } \\
\text { DTN: } \\
\text { SNL01B0505930 } \\
1.003 .\end{array}$ & $\begin{array}{l}\text { Superseded by } \\
\text { SNL01B05059 } \\
301.003, \text { not } \\
\text { used }\end{array}$ \\
\hline SNL02000000011.000 & $\begin{array}{l}\text { MATRIX } \\
\text { COMPRESSIVE } \\
\text { TESTS OF THE } \\
\text { TOPOPAH SPRING } \\
\text { MEMBER IN USW } \\
\text { GU-3. }\end{array}$ & $\begin{array}{l}\text { MATRIX COMPRESSIVE } \\
\text { TESTS OF THE TOPOPAH } \\
\text { SPRING MEMBER IN USW } \\
\text { GU-3 }\end{array}$ & A & $U$ & $\begin{array}{l}\text { UNIAXIAL } \\
\text { COMPRESSION } \\
\text { TEST ON TUFF } \\
\text { FROM NEVADA } \\
\text { TEST SITE }\end{array}$ & $\begin{array}{l}\text { Repeats or } \\
\text { summarizes } \\
\text { SNSAND8316 } \\
4600.000, \text { not } \\
\text { used }\end{array}$ \\
\hline SNL02000000012.000 & $\begin{array}{l}\text { UNIAXIAL AND } \\
\text { TRIAXIAL } \\
\text { COMPRESSION } \\
\text { TEST SERIES ON } \\
\text { TOPOPAH SPRING } \\
\text { TUFF. } \\
\end{array}$ & $\begin{array}{l}\text { UNIAXIAL AND TRIAXIAL } \\
\text { COMPRESSION TEST } \\
\text { SERIES ON TOPOPAH } \\
\text { SPRING TUFF }\end{array}$ & A & $\mathrm{U}$ & $\begin{array}{l}\text { UNIAXIAL AND } \\
\text { TRIAXIAL } \\
\text { COMPRESSION } \\
\text { TEST SERIES } \\
\text { ON TOPOPAH } \\
\text { SPRING TUFF. } \\
\end{array}$ & $\begin{array}{l}\text { Supporting } \\
\text { records, not } \\
\text { used }\end{array}$ \\
\hline SNL02021391002.001 & $\begin{array}{l}\text { DIRECT SHEAR TEST } \\
\text { WITH DIFFERENT } \\
\text { BOUNDARY } \\
\text { CONDITIONS. }\end{array}$ & $\begin{array}{l}\text { NORMAL COMPRESSION } \\
\text { AND SHEAR TESTS. }\end{array}$ & $A$ & $\mathrm{U}$ & $\begin{array}{l}\text { Cyclic normal } \\
\text { compression tests } \\
\text { on multiple } \\
\text { samples (includes } \\
\text { time, } \\
\text { displacement, } \\
\text { and shear load) } \\
\end{array}$ & $\begin{array}{l}\text { Supporting } \\
\text { records, not } \\
\text { used }\end{array}$ \\
\hline SNL02030180001.001 & $\begin{array}{l}\text { MATRIX } \\
\text { COMPRESSIVE } \\
\text { TESTS TO } \\
\text { CHARACTERIZE } \\
\text { TUFFS FROM UE- } \\
\text { 25A\#1 AND THE } \\
\text { LASER DRIFT IN G- } \\
\text { TUNNEL. }\end{array}$ & $\begin{array}{l}\text { MATRIX COMPRESSIVE } \\
\text { TESTS TO } \\
\text { CHARACTERIZE TUFFS } \\
\text { FROM UE-25A\#1 AND THE } \\
\text { LASER DRIFT IN G- } \\
\text { TUNNEL. }\end{array}$ & A & $\mathrm{U}$ & $\begin{array}{l}\text { Data summaries } \\
(1-2 p) \text { contain } \\
\text { some Poisson } \\
\text { and Young's } \\
\text { measurements for } \\
\text { UE-25 \#1 } \\
\text { samples. }\end{array}$ & $\begin{array}{l}\text { Corroborating, } \\
\text { carried forward } \\
\text { for evaluation }\end{array}$ \\
\hline SNL02030193001.001 & $\begin{array}{l}\text { MECHANICAL } \\
\text { PROPERTIES DATA } \\
\text { FOR DRILLHOLE } \\
\text { USW NRG-6 } \\
\text { SAMPLES FROM } \\
\text { DEPTH } 22.2 \text { FT. TO } \\
\text { 328.7 FT. }\end{array}$ & $\begin{array}{l}\text { ULTRASONIC } \\
\text { VELOCITIES, STATIC } \\
\text { ELASTIC PROPERTIES, \& } \\
\text { UNCONFINED } \\
\text { STRENGTH. VA } \\
\text { SUPPORTING DATA. }\end{array}$ & A & QV & $\begin{array}{l}\text { Unconfined } \\
\text { Compression } \\
\text { Tests of Porosity } \\
\text { and Static Elastic } \\
\text { Properties } \\
\text { (Poisson and } \\
\text { Young's values) } \\
\text { from USW NRG-6 }\end{array}$ & Directly Used \\
\hline
\end{tabular}


Table 1. DTNs Containing Potentially Relevant Data for Poisson's Ratio and Young's Modulus (Continued)

\begin{tabular}{|c|c|c|c|c|c|c|}
\hline DTN & TITLE & DESCRIPTION & TYPE & $\begin{array}{l}\text { STATUS } \\
\text { (AT } \\
\text { START } \\
\text { OF } \\
\text { REVIEW) } \\
\end{array}$ & COMMENTS & DISPOSITION \\
\hline SNL02030193001.002 & $\begin{array}{l}\text { MECHANICAL } \\
\text { PROPERTIES DATA } \\
\text { FOR DRILLHOLE } \\
\text { USW NRG-6 } \\
\text { SAMPLES FROM } \\
\text { DEPTH } 22.2 \text { FT TO } \\
\text { 427.0 FT. }\end{array}$ & $\begin{array}{l}\text { ULTRASONIC } \\
\text { VELOCITIES, STATIC } \\
\text { ELASTIC PROPERTIES, } \\
\text { UNCONFINED } \\
\text { STRENGTH, TRIAXIAL } \\
\text { STRENGTH, TENSILE } \\
\text { STRENGTH, \& AVERAGE } \\
\text { GRAIN DENSITY. VA } \\
\text { SUPPORTING DATA. } \\
\end{array}$ & A & QV & $\begin{array}{l}\text { Unconfined } \\
\text { Compression } \\
\text { Tests of Porosity } \\
\text { and Static Elastic } \\
\text { Properties } \\
\text { (Poisson and } \\
\text { Young's values) } \\
\text { from USW NRG-6 }\end{array}$ & Directly Used \\
\hline SNL02030193001.003 & $\begin{array}{l}\text { MECHANICAL } \\
\text { PROPERTIES DATA } \\
\text { FOR DRILLHOLE UE- } \\
\text { 25NRG\#2 SAMPLES } \\
\text { FROM DEPTH } 170.4 \\
\text { FT. TO 200.0 FT. }\end{array}$ & $\begin{array}{l}\text { ULTRASONIC } \\
\text { VELOCITIES, STATIC } \\
\text { ELASTIC PROPERTIES, } \\
\text { UNCONFINED } \\
\text { STRENGTH, TENSILE } \\
\text { STRENGTH, \& AVERAGE } \\
\text { GRAIN DENSITY. }\end{array}$ & A & QV & $\begin{array}{l}\text { Young's Modulus, } \\
\text { Poisson's Ratio, } \\
\text { and Compressive } \\
\text { Strength data of } \\
\text { samples from } \\
\text { borehole UE-25 } \\
\text { NRG \#2 }\end{array}$ & Directly Used \\
\hline SNL02030193001.004 & $\begin{array}{l}\text { MECHANICAL } \\
\text { PROPERTIES DATA } \\
\text { FOR DRILLHOLE } \\
\text { USW NRG-6 } \\
\text { SAMPLES FROM } \\
\text { DEPTH 462.3 FT. TO } \\
\text { 1085.0 FT. }\end{array}$ & $\begin{array}{l}\text { ULTRASONIC } \\
\text { VELOCITIES, STATIC } \\
\text { ELASTIC PROPERTIES, } \\
\text { UNCONFINED } \\
\text { STRENGTH, \& AVERAGE } \\
\text { GRAIN DENSITY. VA } \\
\text { SUPPORTING DATA. }\end{array}$ & $A$ & QV & $\begin{array}{l}\text { Static Poisson } \\
\text { and Young's } \\
\text { values from USW } \\
\text { NRG-6 samples. }\end{array}$ & Directly Used \\
\hline SNL02030193001.005 & $\begin{array}{l}\text { MECHANICAL } \\
\text { PROPERTIES DATA } \\
\text { FOR DRILLHOLE UE- } \\
\text { 25NRG\#3 SAMPLES } \\
\text { FROM DEPTH } 15.4 \\
\text { FT. TO 297.1 FT. }\end{array}$ & $\begin{array}{l}\text { ULTRASONIC } \\
\text { VELOCITIES, STATIC } \\
\text { ELASTIC PROPERTIES, } \\
\text { UNCONFINED } \\
\text { STRENGTH, TENSILE } \\
\text { STRENGTH, \& AVERAGE } \\
\text { GRAIN DENSITY. }\end{array}$ & A & QNV & $\begin{array}{l}\text { Young's Modulus, } \\
\text { Poisson's Ratio, } \\
\text { and Compressive } \\
\text { Strength data } \\
\text { from Unconfined } \\
\text { Compression } \\
\text { Tests from UE-25 } \\
\text { NRG \#3 }\end{array}$ & Directly Used \\
\hline SNL02030193001.006 & \begin{tabular}{|l|} 
MECHANICAL \\
PROPERTIES DATA \\
FOR DRILL HOLE UE- \\
25NRG\#2A SAMPLES \\
FROM DEPTH 90.0 \\
FT. TO 254.5 FT.
\end{tabular} & $\begin{array}{l}\text { ULTRASONIC } \\
\text { VELOCITIES, STATIC } \\
\text { ELASTIC PROPERTIES, } \\
\text { UNCONFINED } \\
\text { STRENGTH, TENSILE } \\
\text { STRENGTH, \& AVERAGE } \\
\text { GRAIN DENSITY. } \\
\end{array}$ & A & QV & $\begin{array}{l}\text { Young's Modulus, } \\
\text { Poisson's Ratio } \\
\text { and Compressive } \\
\text { Strength data } \\
\text { from UE-25 NRG } \\
\text { \#2a }\end{array}$ & Directly Used \\
\hline SNL02030193001.007 & $\begin{array}{l}\text { MECHANICAL } \\
\text { PROPERTIES DATA } \\
\text { FOR DRILL HOLE UE- } \\
\text { 25NRG\#3 SAMPLES } \\
\text { FROM DEPTH } 263.3 \\
\text { FT. TO 265.7 FT. }\end{array}$ & $\begin{array}{l}\text { ULTRASONIC } \\
\text { VELOCITIES, STATIC } \\
\text { ELASTIC PROPERTIES, } \\
\text { TRIAXIAL STRENGTH, \& } \\
\text { AVERAGE GRAIN } \\
\text { DENSITY. }\end{array}$ & $A$ & QV & $\begin{array}{l}\text { Young's Modulus, } \\
\text { Poisson's Ratio } \\
\text { and Compressive } \\
\text { Strength data } \\
\text { from samples } \\
\text { taken from } \\
\text { borehole UE-25 } \\
\text { NRG \#3 } \\
\end{array}$ & Directly Used \\
\hline SNL02030193001.008 & $\begin{array}{l}\text { MECHANICAL } \\
\text { PROPERTIES DATA } \\
\text { FOR DRILL HOLE } \\
\text { USW NRG-6 SAMPLE } \\
\text { 416.0 FT. }\end{array}$ & $\begin{array}{l}\text { ULTRASONIC } \\
\text { VELOCITIES, STATIC } \\
\text { ELASTIC PROPERTIES, } \\
\text { TRIAXIAL STRENGTH, \& } \\
\text { AVERAGE GRAIN } \\
\text { DENSITY. VA } \\
\text { SUPPORTING DATA. }\end{array}$ & $A$ & QV & $\begin{array}{l}\text { Static Elastic } \\
\text { Properties, } \\
\text { Compressive } \\
\text { Strength, } \\
\text { Porosity, and Dry } \\
\text { Bulk Density data } \\
\text { for USW NRG-6 }\end{array}$ & Directly Used \\
\hline
\end{tabular}


Table 1. DTNs Containing Potentially Relevant Data for Poisson's Ratio and Young's Modulus (Continued)

\begin{tabular}{|c|c|c|c|c|c|c|}
\hline DTN & TITLE & DESCRIPTION & TYPE & $\begin{array}{l}\text { STATUS } \\
\text { (AT } \\
\text { START } \\
\text { OF } \\
\text { REVIEW) } \\
\end{array}$ & COMMENTS & DISPOSITION \\
\hline SNL02030193001.012 & $\begin{array}{l}\text { MECHANICAL } \\
\text { PROPERTIES DATA } \\
\text { FOR DRILLHOLE } \\
\text { UE25 NRG-5 } \\
\text { SAMPLES FROM } \\
\text { DEPTH } 847.2 \text { FT. TO } \\
\text { 896.5 FT. }\end{array}$ & $\begin{array}{l}\text { ULTRASONIC } \\
\text { VELOCITIES, STATIC } \\
\text { ELASTIC PROPERTIES, \& } \\
\text { UNCONFINED } \\
\text { STRENGTH. }\end{array}$ & A & QV & $\begin{array}{l}\text { Young's Modulus, } \\
\text { Poisson's Ratio, } \\
\text { and Compressive } \\
\text { Strength data } \\
\text { from Unconfined } \\
\text { Compression } \\
\text { Tests of UE-25 } \\
\text { NRG \#5 }\end{array}$ & Directly Used \\
\hline SNL02030193001.013 & $\begin{array}{l}\text { MECHANICAL } \\
\text { PROPERTIES DATA } \\
\text { FOR DRILLHOLE } \\
\text { UE25 NRG-2B } \\
\text { SAMPLES FROM } \\
\text { DEPTH } 2.7 \text { FT. TO } \\
\text { 87.6 FT. }\end{array}$ & $\begin{array}{l}\text { ULTRASONIC } \\
\text { VELOCITIES, STATIC } \\
\text { ELASTIC PROPERTIES, } \\
\text { UNCONFINED } \\
\text { STRENGTH, TENSILE } \\
\text { STRENGTH, \& POROSITY. }\end{array}$ & $A$ & QNV & $\begin{array}{l}\text { Young's Modulus, } \\
\text { Poisson's Ration } \\
\text { and Compressive } \\
\text { Strength data } \\
\text { from Unconfined } \\
\text { Compression } \\
\text { Tests from UE-25 } \\
\text { NRG \#2b, } \\
\text { 11/04/1993. }\end{array}$ & Directly Used \\
\hline SNL02030193001.014 & $\begin{array}{l}\text { MECHANICAL } \\
\text { PROPERTIES DATA } \\
\text { FOR DRILLHOLE } \\
\text { UE25 NRG-4 } \\
\text { SAMPLES FROM } \\
\text { DEPTH } 378.1 \text { FT. TO } \\
695.8 \text { FT. }\end{array}$ & $\begin{array}{l}\text { GRAIN DENSITY, } \\
\text { POROSITY, UNCONFINED } \\
\text { STRENGTH, ELASTIC } \\
\text { PROPERTIES, \& } \\
\text { INDIRECT TENSILE } \\
\text { STRENGTH. }\end{array}$ & A & QV & $\begin{array}{l}\text { Young's Modulus, } \\
\text { Poisson's Ratio } \\
\text { and Compressive } \\
\text { Strength data } \\
\text { from Unconfined } \\
\text { Compression } \\
\text { tests from UE-25 } \\
\text { NRG \#4 } \\
\end{array}$ & Directly Used \\
\hline SNL02030193001.015 & $\begin{array}{l}\text { MECHANICAL } \\
\text { PROPERTIES DATA } \\
\text { FOR DRILLHOLE } \\
\text { UE25 NR G-4 } \\
\text { SAMPLES FROM } \\
\text { DEPTH 527.0 FT. }\end{array}$ & $\begin{array}{l}\text { ULTRASONIC } \\
\text { VELOCITIES, STATIC } \\
\text { ELASTIC PROPERTIES, } \\
\text { TRIAXIAL STRENGTH, } \\
\text { DRY BULK DENSITY, \& } \\
\text { POROSITY. }\end{array}$ & A & QNV & $\begin{array}{l}\text { Young's Modulus, } \\
\text { Poisson's Ratio } \\
\text { and Compressive } \\
\text { Strength data } \\
\text { from Confined } \\
\text { Compression } \\
\text { tests from } \\
\text { borehole UE-25 } \\
\text { NRG \#4 }\end{array}$ & Directly Used \\
\hline SNL02030193001.016 & $\begin{array}{l}\text { MECHANICAL } \\
\text { PROPERTIES DATA } \\
\text { FOR DRILLHOLE } \\
\text { USW NRG-7/7A } \\
\text { SAMPLES FROM } \\
\text { DEPTH } 18.0 \text { FT TO } \\
\text { 472.9 FT. }\end{array}$ & $\begin{array}{l}\text { ULTRASONIC } \\
\text { VELOCITIES, STATIC } \\
\text { ELASTIC PROPERTIES, \& } \\
\text { UNCONFINED } \\
\text { STRENGTH. }\end{array}$ & A & QNV & $\begin{array}{l}\text { Static Young's } \\
\text { Modulus, Static } \\
\text { Poisson's Ratio } \\
\text { and Compressive } \\
\text { Strength data } \\
\text { from Unconfined } \\
\text { Compression } \\
\text { Tests from USW } \\
\text { NRG-7a }\end{array}$ & Directly Used \\
\hline SNL02030193001.018 & $\begin{array}{l}\text { MECHANICAL } \\
\text { PROPERTIES DATA } \\
\text { FOR DRILLHOLE } \\
\text { USW NRG-7/7A } \\
\text { SAMPLES FROM } \\
\text { DEPTH 344.4 FT. }\end{array}$ & $\begin{array}{l}\text { ULTRASONIC } \\
\text { VELOCITIES, STATIC } \\
\text { ELASTIC PROPERTIES, } \\
\text { TRIAXIAL STRENGTH, } \\
\text { DRY BULK DENSITY \& } \\
\text { POROSITY. }\end{array}$ & A & QV & $\begin{array}{l}\text { Static Young's } \\
\text { Modulus, Static } \\
\text { Poisson's Ratio, } \\
\text { and Compressive } \\
\text { Strength data } \\
\text { from Confined } \\
\text { Compression } \\
\text { Tests of USW } \\
\text { NRG-7a samples }\end{array}$ & Directly Used \\
\hline
\end{tabular}


Table 1. DTNs Containing Potentially Relevant Data for Poisson's Ratio and Young's Modulus (Continued)

\begin{tabular}{|c|c|c|c|c|c|c|}
\hline DTN & TITLE & DESCRIPTION & TYPE & $\begin{array}{l}\text { STATUS } \\
\text { (AT } \\
\text { START } \\
\text { OF } \\
\text { REVIEW) }\end{array}$ & COMMENTS & DISPOSITION \\
\hline SNL02030193001.019 & $\begin{array}{l}\text { MECHANICAL } \\
\text { PROPERTIES DATA } \\
\text { FOR DRILLHOLE } \\
\text { USW NRG-7/7A } \\
\text { SAMPLES FROM } \\
\text { DEPTH } 507.4 \text { FT. TO } \\
\text { 881.0 FT. }\end{array}$ & $\begin{array}{l}\text { GRAIN DENSITY, } \\
\text { POROSITY, UNCONFINED } \\
\text { STRENGTH, CONFINED } \\
\text { STRENGTH, ELASTIC } \\
\text { PROPERTIES, AND } \\
\text { INDIRECT TENSILE } \\
\text { STRENGTH. }\end{array}$ & A & QV & $\begin{array}{l}\text { Static Young's } \\
\text { Modulus, Static } \\
\text { Poisson's Ratio } \\
\text { and Compressive } \\
\text { Strength data } \\
\text { from } \\
\text { Unconfined/Confi } \\
\text { ned Compression } \\
\text { tests from } \\
\text { borehole USW } \\
\text { NRG-7a }\end{array}$ & Directly Used \\
\hline SNL02030193001.020 & $\begin{array}{l}\text { MECHANICAL } \\
\text { PROPERTIES DATA } \\
\text { FOR DRILLHOLE } \\
\text { USW NRG-7/7A } \\
\text { SAMPLES FROM } \\
\text { DEPTH } 554.7 \text { FT. TO } \\
\text { 1450.1 FT. }\end{array}$ & $\begin{array}{l}\text { ULTRASONIC } \\
\text { VELOCITIES, STATIC } \\
\text { ELASTIC PROPERTIES, } \\
\text { UNCONFINED } \\
\text { STRENGTH, TRIAXIAL } \\
\text { STRENGTH, DRY BULK } \\
\text { DENSITY \& POROSITY. }\end{array}$ & A & QV & $\begin{array}{l}\text { Young Modulus, } \\
\text { Poisson's Ratio } \\
\text { and Compressive } \\
\text { strength data of } \\
\text { Unconfined } \\
\text { Compression test } \\
\text { from USW NRG- } \\
\text { 7a. }\end{array}$ & Directly Used \\
\hline SNL02030193001.021 & $\begin{array}{l}\text { MECHANICAL } \\
\text { PROPERTIES DATA } \\
\text { FOR DRILLHOLE } \\
\text { USW NRG-7/7A } \\
\text { SAMPLES FROM } \\
\text { DEPTH } 345.0 \text { FT. TO } \\
\text { 1408.6 FT. }\end{array}$ & $\begin{array}{l}\text { MECHANICAL } \\
\text { PROPERTIES DATA } \\
\text { (ULTRASONIC } \\
\text { VELOCITIES, STATIC } \\
\text { ELASTIC PROPERTIES, } \\
\text { TRIAXIAL STRENGTH, } \\
\text { DRY BULK DENSITY \& } \\
\text { POROSITY) FOR } \\
\text { DRILLHOLE USW NRG- } \\
\text { 7/7A SAMPLES FROM } \\
\text { DEPTH 345.0 FT. TO } \\
\text { 1408.6 FT. }\end{array}$ & A & QV & $\begin{array}{l}\text { Static Young's } \\
\text { Modulus, Static } \\
\text { Poisson's Ratio } \\
\text { and Compressive } \\
\text { Strength data } \\
\text { from Confined } \\
\text { Compression } \\
\text { Tests from USW } \\
\text { NRG-7a }\end{array}$ & Directly Used \\
\hline SNL02030193001.022 & $\begin{array}{l}\text { MECHANICAL } \\
\text { PROPERTIES DATA } \\
\text { FOR DRILL HOLE } \\
\text { USW NRG-6 } \\
\text { SAMPLES FROM } \\
\text { DEPTH 5.7 FT. TO } \\
\text { 1092.3 FT. }\end{array}$ & $\begin{array}{l}\text { ULTRASONIC } \\
\text { VELOCITIES, STATIC } \\
\text { ELASTIC PROPERTIES, } \\
\text { TRIAXIAL STRENGTH, } \\
\text { DRY BULK DENSITY \& } \\
\text { POROSITY. }\end{array}$ & A & QV & $\begin{array}{l}\text { Static Young's } \\
\text { Modulus, Static } \\
\text { Poisson's Ration } \\
\text { and Compressive } \\
\text { Strength data } \\
\text { from Confined } \\
\text { Compression } \\
\text { Tests from USW } \\
\text { NRG-6 }\end{array}$ & Directly Used \\
\hline SNL02030193001.023 & $\begin{array}{l}\text { MECHANICAL } \\
\text { PROPERTIES DATA } \\
\text { FOR DRILLHOLE } \\
\text { USW SD-12 } \\
\text { SAMPLES FROM } \\
\text { DEPTH } 16.1 \text { FT TO } \\
\text { 1300.3 FT. }\end{array}$ & $\begin{array}{l}\text { MECHANICAL } \\
\text { PROPERTIES DATA } \\
\text { (ULTRASONIC } \\
\text { VELOCITIES, STATIC } \\
\text { ELASTIC PROPERTIES, } \\
\text { UNCONFINED } \\
\text { STRENGTH, TRIAXIAL } \\
\text { STRENGTH, DRY BULK } \\
\text { DENSITY \& POROSITY) } \\
\text { FOR DRILLHOLE USW SD- } \\
\text { 12 SAMPLES FROM } \\
\text { DEPTH 16.1 FT TO } 1300.3 \\
\text { FT. }\end{array}$ & A & QV & $\begin{array}{l}\text { Static Young's } \\
\text { Modulus, Static } \\
\text { Poisson's Ratio } \\
\text { and Compressive } \\
\text { Strength data } \\
\text { from Pressure } \\
\text { Effects tests from } \\
\text { borehole USW } \\
\text { SD-12, } \\
07 / 17 / 1995 \text { to } \\
07 / 31 / 1995 .\end{array}$ & Directly Used \\
\hline
\end{tabular}


Table 1. DTNs Containing Potentially Relevant Data for Poisson's Ratio and Young's Modulus (Continued)

\begin{tabular}{|c|c|c|c|c|c|c|}
\hline DTN & TITLE & DESCRIPTION & TYPE & $\begin{array}{l}\text { STATUS } \\
\text { (AT } \\
\text { START } \\
\text { OF } \\
\text { REVIEW) } \\
\end{array}$ & COMMENTS & DISPOSITION \\
\hline SNL02030193001.024 & $\begin{array}{l}\text { ELEVATED } \\
\text { TEMPERATURE } \\
\text { CONFINED } \\
\text { COMPRESSION } \\
\text { TESTS }\end{array}$ & \begin{tabular}{|l|} 
(ULTRASONIC \\
VELOCITIES, STATIC \\
ELASTIC PROPERTIES, \\
UNCONFINED \\
STRENGTH, TRIAXIAL \\
STRENGTH, DRY BULK \\
DENSITY \& POROSITY) \\
FOR DRILLHOLE USW SD- \\
9 SAMPLES FROM DEPTH \\
52.6 FT. TO 2222.9 FT. \\
\end{tabular} & A & QV & $\begin{array}{l}\text { Young's Modulus, } \\
\text { Poisson's Ratio } \\
\text { and Compressive } \\
\text { Strength data } \\
\text { from Elevated } \\
\text { Temperature } \\
\text { Confined } \\
\text { Compression } \\
\text { Tests from USW } \\
\text { SD-9 } \\
\end{array}$ & Directly Used \\
\hline SNL02030193001.025 & $\begin{array}{l}\text { MECHANICAL } \\
\text { PROPERTIES DATA } \\
\text { FOR BOREHOLE } \\
\text { USW SD-9. }\end{array}$ & $\begin{array}{l}\text { THIS DATA HAS BEEN } \\
\text { SUPERSEDED BY DTN: } \\
\text { SNL02030193001.026. }\end{array}$ & A & Q & $\begin{array}{l}\text { Data has been } \\
\text { superseded by } \\
\text { SNL0203019300 } \\
1.026\end{array}$ & $\begin{array}{l}\text { Superseded, } \\
\text { not used }\end{array}$ \\
\hline SNL02030193001.026 & $\begin{array}{l}\text { MECHANICAL } \\
\text { PROPERTIES DATA } \\
\text { FOR BOREHOLE } \\
\text { USW SD-9. }\end{array}$ & $\begin{array}{l}\text { THIS DATA SUPERSEDES } \\
\text { DATA PREVIOUSLY } \\
\text { IDENTIFIED BY DTN: } \\
\text { SNL02030193001.025. }\end{array}$ & A & QV & $\begin{array}{l}\text { Young's Modulus, } \\
\text { Poisson's Ratio } \\
\text { and Compressive } \\
\text { Strength data } \\
\text { from Pressure } \\
\text { Effects Tests from } \\
\text { borehole USW } \\
\text { SD-9. }\end{array}$ & Directly Used \\
\hline SNL02030193001.028 & $\begin{array}{l}\text { CONFINED } \\
\text { COMPRESSION } \\
\text { EXPERIMENTS AT } \\
150 \text { DEGREES C ON } \\
\text { TSW2 TUFF FROM } \\
\text { BOREHOLE USW SD- } \\
9 .\end{array}$ & $\begin{array}{l}\text { CONFINED } \\
\text { COMPRESSION } \\
\text { EXPERIMENTS AT } 150 \\
\text { DEGREES C ON TSW2 } \\
\text { TUFF FROM BOREHOLE } \\
\text { USW SD-9 }\end{array}$ & A & QV & $\begin{array}{l}\text { Young's Modulus, } \\
\text { Poisson's Ratio } \\
\text { and Compressive } \\
\text { Strength data } \\
\text { from Elevated } \\
\text { Temperature } \\
\text { Confined } \\
\text { Compression } \\
\text { Tests from } \\
\text { borehole USW } \\
\text { SD-9 }\end{array}$ & Directly Used \\
\hline SNL02033084001.001 & $\begin{array}{l}\text { MATRIX } \\
\text { COMPRESSIVE } \\
\text { TESTS OF THE } \\
\text { TOPOPAH SPRING } \\
\text { MEMBER IN USW G- } \\
2 .\end{array}$ & $\begin{array}{l}\text { MATRIX COMPRESSIVE } \\
\text { TESTS OF THE TOPOPAH } \\
\text { SPRING MEMBER IN USW } \\
\text { G-2. }\end{array}$ & A & $\mathrm{U}$ & $\begin{array}{l}\text { Calibration And } \\
\text { Test Data: } \\
\text { Compressive } \\
\text { Tests Of The } \\
\text { Topopah Spring } \\
\text { Member In USW } \\
\text { G-2 (C) } \\
\end{array}$ & $\begin{array}{l}\text { Supporting } \\
\text { records, not } \\
\text { used }\end{array}$ \\
\hline SNL02033084002.001 & \begin{tabular}{l|} 
PARAMETER \\
EFFECTS ON \\
MATRIX \\
COMPRESSIVE \\
PROPERTIES OF \\
THE TOPOPAH \\
SPRING MEMBER AT \\
BUSTED BUTTE. \\
\end{tabular} & $\begin{array}{l}\text { PARAMETER EFFECTS } \\
\text { ON MATRIX } \\
\text { COMPRESSIVE } \\
\text { PROPERTIES OF THE } \\
\text { TOPOPAH SPRING } \\
\text { MEMBER AT BUSTED } \\
\text { BUTTE. }\end{array}$ & A & $\mathrm{U}$ & $\begin{array}{l}\text { Constant strain } \\
\text { rate testing on } \\
\text { Topopah Spring } \\
\text { Tuff reported in } \\
\text { RSI/TLM-144, } \\
5 / 21 / 87 .\end{array}$ & $\begin{array}{l}\text { Corroborating, } \\
\text { carried forward } \\
\text { for evaluation }\end{array}$ \\
\hline SNL02040184001.001 & $\begin{array}{l}\text { EFFECTS OF } \\
\text { LITHOPHYSAE ON } \\
\text { THE MATRIX } \\
\text { COMPRESSIVE } \\
\text { PROPERTIES. }\end{array}$ & $\begin{array}{l}\text { PHYSICAL PROPERTIES } \\
\text { AND LITHOPHYSAL } \\
\text { DETERMINATION FOR } \\
\text { LARGE DIAMETER } \\
\text { SAMPLES OF THE } \\
\text { TOPOPAH SPRING } \\
\text { MEMBER AT BUSTED } \\
\text { BUTTE. }\end{array}$ & $A$ & $\mathrm{U}$ & \begin{tabular}{|l|} 
Test Report For \\
Samples For \\
Uniaxial \\
Compression \\
Test On Large \\
Lithophysal \\
Samples Of \\
Busted Butte Tuff \\
\end{tabular} & $\begin{array}{l}\text { Supporting } \\
\text { records, not } \\
\text { used }\end{array}$ \\
\hline
\end{tabular}


Table 1. DTNs Containing Potentially Relevant Data for Poisson's Ratio and Young's Modulus (Continued)

\begin{tabular}{|c|c|c|c|c|c|c|}
\hline DTN & TITLE & DESCRIPTION & TYPE & $\begin{array}{l}\text { STATUS } \\
\text { (AT } \\
\text { START } \\
\text { OF } \\
\text { REVIEW) }\end{array}$ & COMMENTS & DISPOSITION \\
\hline SNL02040687003.001 & $\begin{array}{l}\text { MECHANICAL } \\
\text { PROPERTY DATA TO } \\
\text { ANALYZE THE } \\
\text { RESPONSE OF } \\
\text { SAMPLES OF UNIT } \\
\text { TSW2 TO HIGH } \\
\text { TEMPERATURE } \\
\text { AND/OR LOW } \\
\text { STRAIN RATES. }\end{array}$ & $\begin{array}{l}\text { COMPRESSIVE TESTS AT } \\
22 \text { DEGREES } \\
\text { CENTIGRADE, 10-9 S-1, } \\
\text { PC=PP=0.1 MPA. }\end{array}$ & A & $\mathrm{U}$ & $\begin{array}{l}\text { DATA FROM } \\
\text { FILE, } \\
\text { cla1214p.DAT, } \\
\text { Data From A Set } \\
\text { of Six } \\
\text { Experiments At } \\
\text { Room Pressure } \\
\text { And Temperature } \\
\text { And an Axial } \\
\text { Strain Rate Of 10- } \\
9 \text { S-1 }\end{array}$ & $\begin{array}{l}\text { Corroborating, } \\
\text { carried forward } \\
\text { for evaluation }\end{array}$ \\
\hline SNL02040687004.001 & $\begin{array}{l}\text { CREEP IN TOPOPAH } \\
\text { SPRING MEMBER } \\
\text { WELDED TUFF. }\end{array}$ & $\begin{array}{l}\text { SANDIA REPORT, } \\
\text { SAND } 94-2585 \text { BY R. J. } \\
\text { MARTIN III, R. H. PRICE, } \\
\text { P.J. BOYD, AND J. S. } \\
\text { NOEL. }\end{array}$ & A & QNV & $\begin{array}{l}\text { Laboratory } \\
\text { analyses of creep } \\
\text { in Topopah } \\
\text { Spring Welded } \\
\text { Tuff from Busted } \\
\text { Butte } \\
\end{array}$ & Directly Used \\
\hline SNL02062685001.001 & $\begin{array}{l}\text { DETERMINATIONS } \\
\text { OF THE EFFECT OF } \\
\text { SAMPLE SIZE ON } \\
\text { THE MECHANICAL } \\
\text { PROPERTIES OF } \\
\text { THE WELDED } \\
\text { TOPOPAH SPRING } \\
\text { MEMBER, BUSTED } \\
\text { BUTTE. }\end{array}$ & $\begin{array}{l}\text { DETERMINATIONS OF } \\
\text { THE EFFECT OF SAMPLE } \\
\text { SIZE ON THE } \\
\text { MECHANICAL } \\
\text { PROPERTIES OF THE } \\
\text { WELDED TOPOPAH } \\
\text { SPRING MEMBER, } \\
\text { BUSTED BUTTE. }\end{array}$ & A & $\mathrm{U}$ & $\begin{array}{l}\text { Uniaxial } \\
\text { compressive } \\
\text { stress } \\
\text { measurements on } \\
\text { Welded Topopah } \\
\text { Spring Member, } \\
\text { Busted Butte. }\end{array}$ & $\begin{array}{l}\text { Supporting } \\
\text { records, not } \\
\text { used }\end{array}$ \\
\hline SNL02072983001.001 & \begin{tabular}{|l|} 
LABORATORY \\
COMPARISON OF \\
MECHANICAL \\
COMPRESSIVE DATA \\
FROM MATRIX \\
COMPRESSIVE \\
TESTS USING \\
BUSTED BUTTE \\
OUTCROP SAMPLES. \\
\end{tabular} & $\begin{array}{l}\text { LABORATORY } \\
\text { COMPARISON OF } \\
\text { MECHANICAL } \\
\text { COMPRESSIVE DATA } \\
\text { FROM MATRIX } \\
\text { COMPRESSIVE TESTS } \\
\text { USING BUSTED BUTTE } \\
\text { OUTCROP SAMPLES. } \\
\end{array}$ & A & $\mathrm{U}$ & $\begin{array}{l}\text { Summary of } \\
\text { triaxial } \\
\text { compressive } \\
\text { stress } \\
\text { measurements on } \\
\text { Busted Butte } \\
\text { outcrop material. }\end{array}$ & $\begin{array}{l}\text { Corroborating, } \\
\text { carried forward } \\
\text { for evaluation }\end{array}$ \\
\hline SNL02072983002.001 & \begin{tabular}{|l|} 
LABORATORY \\
COMPARISON OF \\
MECHANICAL \\
COMPRESSIVE DATA \\
FROM MATRIX \\
COMPRESSIVE \\
TESTS USING \\
BUSTED BUTTE \\
OUTCROP SAMPLES. \\
\end{tabular} & $\begin{array}{l}\text { LABORATORY } \\
\text { COMPARISON OF } \\
\text { MECHANICAL } \\
\text { COMPRESSIVE DATA } \\
\text { FROM MATRIX } \\
\text { COMPRESSIVE TESTS } \\
\text { USING BUSTED BUTTE } \\
\text { OUTCROP SAMPLES. } \\
\end{array}$ & A & U & $\begin{array}{l}\text { Laboratory } \\
\text { Comparison Of } \\
\text { Mechanical } \\
\text { Compressive } \\
\text { Data From Matrix } \\
\text { Compressive } \\
\text { Tests Using } \\
\text { Busted Butte } \\
\text { Outcrop Samples. }\end{array}$ & $\begin{array}{l}\text { Supporting } \\
\text { records, not } \\
\text { used }\end{array}$ \\
\hline SNL02072983003.001 & \begin{tabular}{|l|} 
LABORATORY \\
COMPARISON OF \\
MECHANICAL \\
COMPRESSIVE DATA \\
FROM MATRIX \\
COMPRESSIVE \\
TESTS USING THE \\
BUSTED BUTTE \\
OUTCROP SAMPLES.
\end{tabular} & $\begin{array}{l}\text { LABORATORY } \\
\text { COMPARISON OF } \\
\text { MECHANICAL } \\
\text { COMPRESSIVE DATA } \\
\text { FROM MATRIX } \\
\text { COMPRESSIVE TESTS } \\
\text { USING THE BUSTED } \\
\text { BUTTE OUTCROP } \\
\text { SAMPLES. }\end{array}$ & $A$ & $U$ & $\begin{array}{l}\text { Triaxial } \\
\text { compressive tests } \\
\text { on Topopah } \\
\text { Spring tuff at } \\
\text { Busted Butte } \\
\text { used as } \\
\text { comparison. }\end{array}$ & $\begin{array}{l}\text { Corroborating, } \\
\text { carried forward } \\
\text { for evaluation }\end{array}$ \\
\hline
\end{tabular}


Table 1. DTNs Containing Potentially Relevant Data for Poisson's Ratio and Young's Modulus (Continued)

\begin{tabular}{|c|c|c|c|c|c|c|}
\hline DTN & TITLE & DESCRIPTION & TYPE & $\begin{array}{l}\text { STATUS } \\
\text { (AT } \\
\text { START } \\
\text { OF } \\
\text { REVIEW) } \\
\end{array}$ & COMMENTS & DISPOSITION \\
\hline SNL02100181001.001 & $\begin{array}{l}\text { LABORATORY } \\
\text { COMPARISON OF } \\
\text { MATRIX } \\
\text { COMPRESSIVE } \\
\text { TESTS USING THE } \\
\text { CALICO HILLS } \\
\text { MEMBER IN USW G-1 }\end{array}$ & $\begin{array}{l}\text { LABORATORY } \\
\text { COMPARISON OF MATRIX } \\
\text { COMPRESSIVE TESTS } \\
\text { USING THE CALICO HILLS } \\
\text { MEMBER IN USW G-1. }\end{array}$ & A & U & $\begin{array}{l}\text { Individual uniaxial } \\
\text { and triaxial tests } \\
\text { on Calico Hills } \\
\text { Member in USW } \\
\text { G-1 }\end{array}$ & $\begin{array}{l}\text { Supporting } \\
\text { records, not } \\
\text { used }\end{array}$ \\
\hline SNL02100196001.001 & \begin{tabular}{|l|} 
UNCONFINED \\
COMPRESSION \\
TESTS ON \\
SPECIMENS FROM \\
THE DRIFT SCALE \\
TEST AREA OF THE \\
EXPLORATORY \\
STUDIES FACILITY \\
AT YUCCA \\
MOUNTAIN, NEVADA. \\
\end{tabular} & VA SUPPORTING DATA. & A & QNV & $\begin{array}{l}\text { Static Young's } \\
\text { Modulus data of } \\
\text { Drift Scale } \\
\text { Characterization } \\
\text { specimens from } \\
\text { the Drift Scale } \\
\text { Test Area of the } \\
\text { Exploratory } \\
\text { Studies Facility }\end{array}$ & Directly Used \\
\hline SNL02120584001.001 & $\begin{array}{l}\text { MATRIX } \\
\text { COMPRESSIVE } \\
\text { TESTS TO } \\
\text { DETERMINE } \\
\text { PARAMETER } \\
\text { EFFECTS. }\end{array}$ & $\begin{array}{l}\text { TEMPERATURE, } \\
\text { PRESSURE, STRAIN } \\
\text { RATE AND SATURATION } \\
\text { ON MECHANICAL } \\
\text { PROPERTIES OF THE } \\
\text { TOPOPAH SPRING } \\
\text { MEMBER. } \\
\end{array}$ & $A$ & U & $\begin{array}{l}\text { Compression } \\
\text { Tests For Nnwsi } \\
\text { Test Series On } \\
10-\text { Ae Tuff } \\
\text { "Busted Butte" } \\
100 \% \text { Saturated }\end{array}$ & $\begin{array}{l}\text { Supporting } \\
\text { records, not } \\
\text { used }\end{array}$ \\
\hline SNL04021384001.001 & $\begin{array}{l}\text { CHARACTERIZATION } \\
\text { OF SAMPLES IN } \\
\text { SUPPORT OF } \\
\text { MECHANICAL } \\
\text { TESTING ON } \\
\text { DENSELY WELDED } \\
\text { SAMPLES OF THE } \\
\text { TOPOPAH SPRING } \\
\text { MEMBER FROM } \\
\text { BUSTED BUTTE. } \\
\end{array}$ & $\begin{array}{l}\text { CHARACTERIZATION OF } \\
\text { SAMPLES IN SUPPORT } \\
\text { OF MECHANICAL } \\
\text { TESTING ON DENSELY } \\
\text { WELDED SAMPLES OF } \\
\text { THE TOPOPAH SPRING } \\
\text { MEMBER FROM BUSTED } \\
\text { BUTTE. }\end{array}$ & A & $\mathrm{U}$ & $\begin{array}{l}\text { Compression } \\
\text { Tests On 10-Ae } \\
\text { Tuff "Busted- } \\
\text { Butte" } 100 \% \\
\text { Saturated } 22 \\
\text { Degrees C }\end{array}$ & $\begin{array}{l}\text { Supporting } \\
\text { records, not } \\
\text { used }\end{array}$ \\
\hline SNL04041990001.001 & $\begin{array}{l}\text { USW G-1 PROBE } \\
\text { DATA TOPOPAH } \\
\text { SPRING MEMBER. }\end{array}$ & $\begin{array}{l}\text { USW G-1 PROBE DATA } \\
\text { TOPOPAH SPRING } \\
\text { MEMBER. }\end{array}$ & A & $U$ & $\begin{array}{l}\text { Chemical } \\
\text { Composition } \\
\text { Data-Topopah } \\
\text { Spring, } \\
\text { Lithophysal } \\
\text { (Vapor Phase } \\
\text { Altered) Matrix } \\
\end{array}$ & $\begin{array}{l}\text { Supporting } \\
\text { records, not } \\
\text { used }\end{array}$ \\
\hline SNL22080196001.002 & \begin{tabular}{|l|} 
UNCONFINED \\
COMPRESSION \\
TESTS ON \\
SPECIMENS FROM \\
THE SINGLE HEATER \\
TEST AREA IN THE \\
THERMAL TESTING \\
FACILITY AT YUCCA \\
MOUNTAIN, NEVADA.
\end{tabular} & VA SUPPORTING DATA. & A & QV & $\begin{array}{l}\text { Young's Modulus, } \\
\text { Poisson's Ratio, } \\
\text { and Compressive } \\
\text { Strength data } \\
\text { from unconfined } \\
\text { compression tests } \\
\text { in the Single } \\
\text { Heater Test Area } \\
\text { in the ESF }\end{array}$ & Directly Used \\
\hline
\end{tabular}


Table 1. DTNs Containing Potentially Relevant Data for Poisson's Ratio and Young's Modulus (Continued)

\begin{tabular}{|c|c|c|c|c|c|c|}
\hline DTN & TITLE & DESCRIPTION & TYPE & $\begin{array}{l}\text { STATUS } \\
\text { (AT } \\
\text { START } \\
\text { OF } \\
\text { REVIEW) } \\
\end{array}$ & COMMENTS & DISPOSITION \\
\hline SNL22080196001.003 & \begin{tabular}{|l|} 
POSTTEST \\
LABORATORY \\
THERMAL AND \\
MECHANICAL \\
CHARACTERIZATION \\
FOR SINGLE \\
HEATER TEST (SHT) \\
BLOCK.
\end{tabular} & $\begin{array}{l}\text { THESE DATA APPEAR IN } \\
\text { SECTION 5.1 OF THE } \\
\text { SINGLE HEATER TEST } \\
\text { (SHT) FINAL REPORT, } \\
\text { SUBMITTED UNDER DTN: } \\
\text { SNF35110695001.009 }\end{array}$ & A & QNV & $\begin{array}{l}\text { Unconfined } \\
\text { Compression } \\
\text { tests data of Dry } \\
\text { Bulk Density and } \\
\text { Elastic Properties } \\
\text { of the Single } \\
\text { Heater Test, } \\
\text { Posttest } \\
\text { characterization } \\
\text { specimens }\end{array}$ & Directly Used \\
\hline SNL23030598001.001 & \begin{tabular}{|l|} 
UNCONFINED \\
COMPRESSION \\
TESTS ON CAST-IN- \\
PLACE CONCRETE \\
SPECIMENS FROM \\
THE DRIFT SCALE \\
TEST IN THE ESF \\
(EXPLORATORY \\
STUDIES FACILITY) \\
AT YUCCA \\
MOUNTAIN, NEVADA.
\end{tabular} & $\begin{array}{l}\text { UNCONFINED } \\
\text { COMPRESSION TESTS } \\
\text { ON CAST-IN-PLACE } \\
\text { CONCRETE SPECIMENS } \\
\text { FROM THE DRIFT SCALE } \\
\text { TEST IN THE ESF } \\
\text { (EXPLORATORY STUDIES } \\
\text { FACILITY) AT YUCCA } \\
\text { MOUNTAIN, NEVADA. }\end{array}$ & A & Q & $\begin{array}{l}\text { Poisson's Ratio } \\
\text { and Young's } \\
\text { Modulus data of } \\
\text { cast-in-place } \\
\text { concrete } \\
\text { specimens from } \\
\text { the Drift Scale } \\
\text { Test Area of the } \\
\text { ESF, 01/30/1998 } \\
\text { to } 02 / 10 / 1998 .\end{array}$ & $\begin{array}{l}\text { Material not } \\
\text { related, not } \\
\text { used }\end{array}$ \\
\hline SNL23030598001.002 & $\begin{array}{l}\text { INTERIM REPORT } \\
\text { ON CREEP TESTING } \\
\text { OF CAST-IN-PLACE } \\
\text { CONCRETE. }\end{array}$ & $\begin{array}{l}\text { DATA APPEAR IN } \\
\text { APPENDIX E OF THE } \\
\text { REPORT SUBMITTED } \\
\text { UNDER DTN: } \\
\text { SNF39012298002.002. } \\
\text { THESE DATA HAVE BEEN } \\
\text { SUPERSEDED BY DTN: } \\
\text { SNL23030598001.003. }\end{array}$ & A & Q & $\begin{array}{l}\text { Data has been } \\
\text { superseded by } \\
\text { SNL2303059800 } \\
1.003\end{array}$ & $\begin{array}{l}\text { Superseded, } \\
\text { not used }\end{array}$ \\
\hline SNL23030598001.003 & $\begin{array}{l}\text { CREEP TESTING OF } \\
\text { CAST-IN-PLACE } \\
\text { CONCRETE. }\end{array}$ & $\begin{array}{l}\text { THESE DATA } \\
\text { SUPERSEDE DATA } \\
\text { PREVIOUSLY IDENTIFIED } \\
\text { BY DTN: } \\
\text { SNL23030598001.002 }\end{array}$ & A & Q & $\begin{array}{l}\text { Elastic Properties } \\
\text { of cast-in-place } \\
\text { concrete. Data } \\
\text { supersede data } \\
\text { previously } \\
\text { identified by DTN: } \\
\text { SNL2303059800 } \\
1.002 .\end{array}$ & $\begin{array}{l}\text { Material not } \\
\text { related, not } \\
\text { used }\end{array}$ \\
\hline SNL23100198001.001 & $\begin{array}{l}\text { LABORATORY } \\
\text { TESTING OF } \\
\text { CONCRETE } \\
\text { PROPERTIES AT } \\
\text { ELEVATED } \\
\text { TEMPERATURES }\end{array}$ & $\begin{array}{l}\text { LABORATORY TESTING } \\
\text { OF CONCRETE } \\
\text { PROPERTIES AT } \\
\text { ELEVATED } \\
\text { TEMPERATURES } \\
\text { (INCLUDING AGGREGATE } \\
\text { CHARACTERIZATION) }\end{array}$ & A & Q & $\begin{array}{l}\text { Elastic Moduli of } \\
\text { Creep } \\
\text { Specimens, } \\
06 / 01 / 1998 \text { to } \\
12 / 22 / 1998 .\end{array}$ & $\begin{array}{l}\text { Material not } \\
\text { related, not } \\
\text { used }\end{array}$ \\
\hline SNSAND80145300.000 & $\begin{array}{l}\text { ROCK MECHANICS } \\
\text { PROPERTIES OF } \\
\text { VOLCANIC TUFFS } \\
\text { FROM THE NEVADA } \\
\text { TEST SITE. }\end{array}$ & $\begin{array}{l}\text { SAND80-1453. } \\
\text { NNA.870406.0497. VA } \\
\text { SUPPORTING DATA. }\end{array}$ & D & $\mathrm{U}$ & $\begin{array}{l}\text { Mechanical } \\
\text { Properties data of } \\
\text { Tuff Samples } \\
\text { from UE-25 a \#1 }\end{array}$ & $\begin{array}{l}\text { Corroborating, } \\
\text { carried forward } \\
\text { for evaluation }\end{array}$ \\
\hline SNSAND81166400.000 & \begin{tabular}{|l|} 
EFFECTS OF \\
ELEVATED \\
TEMPERATURE AND \\
PORE PRESSURE \\
ON THE \\
MECHANICAL \\
BEHAVIOR OF \\
BULLFROG TUFF.
\end{tabular} & $\begin{array}{l}\text { TRIAXIAL TEST DATA } \\
\text { PRESENTED IN SANDIA } \\
\text { REPORT, SAND81-1664, } \\
\text { BY W. A. OLSSON }\end{array}$ & A & $U$ & $\begin{array}{l}\text { Triaxial Test data } \\
\text { for the Bullfrog } \\
\text { Member of the } \\
\text { Crater Flat Tuff } \\
\text { from USW G-1, } \\
01 / 01 / 1981 \text { to } \\
12 / 01 / 1981 .\end{array}$ & $\begin{array}{l}\text { Corroborating, } \\
\text { carried forward } \\
\text { for evaluation }\end{array}$ \\
\hline
\end{tabular}


Table 1. DTNs Containing Potentially Relevant Data for Poisson's Ratio and Young's Modulus (Continued)

\begin{tabular}{|c|c|c|c|c|c|c|}
\hline DTN & TITLE & DESCRIPTION & TYPE & $\begin{array}{l}\text { STATUS } \\
\text { (AT } \\
\text { START } \\
\text { OF } \\
\text { REVIEW) }\end{array}$ & COMMENTS & DISPOSITION \\
\hline SNSAND82048100.000 & $\begin{array}{l}\text { UNIAXIAL } \\
\text { COMPRESSION } \\
\text { TEST SERIES ON } \\
\text { BULLFROG TUFF. }\end{array}$ & \begin{tabular}{|l|} 
LABORATORY \\
COMPRESSIVE DATA \\
PRESENTED IN SANDIA \\
REPORT, SAND82-0481, \\
BY R. H. PRICE, A. K. \\
JONES, AND K. G. NIMICK
\end{tabular} & A & $\mathrm{U}$ & $\begin{array}{l}\text { Uniaxial } \\
\text { Compression } \\
\text { Test Series } \\
\text { samples from the } \\
\text { Bullfrog Member } \\
\text { of the Crater Flat } \\
\text { Tuff in USW G-1 } \\
\end{array}$ & $\begin{array}{l}\text { Corroborating, } \\
\text { carried forward } \\
\text { for evaluation }\end{array}$ \\
\hline SNSAND82105500.000 & $\begin{array}{l}\text { UNIAXIAL } \\
\text { COMPRESSION } \\
\text { TEST SERIES ON } \\
\text { TRAM TUFF. }\end{array}$ & $\begin{array}{l}\text { LABORATORY } \\
\text { COMPRESSIVE DATA } \\
\text { PRESENTED IN SANDIA } \\
\text { REPORT, SAND82-1055, } \\
\text { BY R. H. PRICE, AND K. G. } \\
\text { NIMICK. }\end{array}$ & A & $U$ & $\begin{array}{l}\text { Uniaxial } \\
\text { Compression } \\
\text { Test series on } \\
\text { samples from the } \\
\text { Tram Tuff } \\
\text { Member of the } \\
\text { Crater Flat Tuff in } \\
\text { USW G-1 }\end{array}$ & $\begin{array}{l}\text { Corroborating, } \\
\text { carried forward } \\
\text { for evaluation }\end{array}$ \\
\hline SNSAND82131400.000 & $\begin{array}{l}\text { UNIAXIAL AND } \\
\text { TRIAXIAL } \\
\text { COMPRESSION } \\
\text { TEST SERIES ON } \\
\text { CALICO HILLS TUFF. }\end{array}$ & $\begin{array}{l}\text { DATA FROM SAND82- } \\
\text { 1314: 1) LOAD CELL } \\
\text { LVDT'S, AND DISK GAGE } \\
\text { CALIBRATION DATA; 2) } \\
\text { ALUMINUM SAMPLE } \\
\text { CALIBRATION DATA; AND } \\
\text { 3) EXPERIMENTAL DATA - } \\
\text { COMPRESSION TESTS. } \\
\end{array}$ & D & $U$ & $\begin{array}{l}\text { Mechanical } \\
\text { Properties data } \\
\text { from Uniaxial and } \\
\text { Triaxial } \\
\text { Compression test } \\
\text { series on Calico } \\
\text { Hills Tuffs }\end{array}$ & $\begin{array}{l}\text { Corroborating, } \\
\text { carried forward } \\
\text { for evaluation }\end{array}$ \\
\hline SNSAND82131500.000 & \begin{tabular}{|l|} 
ANALYSIS OF ROCK \\
MECHANICS \\
PROPERTIES OF \\
VOLCANIC TUFF \\
UNITS FROM YUCCA \\
MOUNTAIN, NEVADA \\
TEST SITE. \\
\end{tabular} & $\begin{array}{l}\text { SANDIA REPORT, } \\
\text { SAND82-1315, BY R. H. } \\
\text { PRICE. VA SUPPORTING } \\
\text { DATA. }\end{array}$ & D & $U$ & $\begin{array}{l}\text { Analysis of rock } \\
\text { mechanics } \\
\text { properties of } \\
\text { volcanic tuff units } \\
\text { from Yucca } \\
\text { Mountain }\end{array}$ & $\begin{array}{l}\text { Repeats or } \\
\text { Summarizes, } \\
\text { not used }\end{array}$ \\
\hline SNSAND82172300.000 & $\begin{array}{l}\text { LOAD CELL LVDT'S } \\
\text { AND DISK GAGE } \\
\text { CALIBRATION DATA; } \\
\text { ALUMINUM SAMPLE } \\
\text { CALIBRATION DATA } \\
\text { I.D. MN LOAD } \\
\text { FRAME; LOAD CELL, } \\
\text { LVDT'S AND DISK } \\
\text { GAGE CALIBRATION } \\
\text { DATA } 1.8 \text { MN FRAME; } \\
\text { AND ALUMINUM } \\
\text { SAMPLE } \\
\text { CALIBRATION DATA - } \\
\text { COMPRESSION } \\
\text { TESTS. }\end{array}$ & $\begin{array}{l}\text { DEVELOPED DATA FROM } \\
\text { SAND 82-1723: 1) LOAD } \\
\text { CELL LVDT'S AND DISK } \\
\text { GAGE CALIBRATION } \\
\text { DATA; 2) ALUMINUM } \\
\text { SAMPLE CALIBRATION } \\
\text { DATA I.D. MN LOAD } \\
\text { FRAME; 3) LOAD CELL, } \\
\text { LVDT'S AND DISK GAGE } \\
\text { CALIBRATION DATA } 1.8 \\
\text { MN FRAME; 4) ALUMINUM } \\
\text { SAMPLE CALIBRATION } \\
\text { DATA - COMPRESSION } \\
\text { TESTS. THESE DATA } \\
\text { HAVE BEEN } \\
\text { SUPERSEDED BY DTN: } \\
\text { SN0108SD821723.001. }\end{array}$ & D & $U$ & $\begin{array}{l}\text { Data has been } \\
\text { superseded by } \\
\text { SN0108SD } 82172 \\
3.001\end{array}$ & $\begin{array}{l}\text { Superseded, } \\
\text { not used }\end{array}$ \\
\hline SNSAND83164600.000 & $\begin{array}{l}\text { EXPERIMENTAL } \\
\text { DATA OF FULLY } \\
\text { SATURATED AND } \\
\text { WET SAMPLES; } \\
\text { STATIC } \\
\text { MECHANICAL } \\
\text { PROPERTIES OF GU- } \\
3 \text { 760.9 SAMPLES; } \\
\text { ULTRASONIC } \\
\text { VELOCITY DATA; } \\
\text { AND DYNAMIC } \\
\end{array}$ & $\begin{array}{l}\text { 1) LOAD CELL LVDT AND } \\
\text { DISK GAGE CALIBRATION } \\
\text { DATA; 2) ALUMINUM } \\
\text { SAMPLE CALIBRATION } \\
\text { DATA; 3) SAMPLE DATA; } \\
\text { 4) BRIEF SAMPLE } \\
\text { DESCRIPTIONS; 5) BRIEF } \\
\text { SAMPLE DESCRIPTIONS - } \\
\text { SYMBOLS KEY; 6) } \\
\text { EXPERIMENTAL DATA - } \\
\text { FULLY SATURATED }\end{array}$ & D & U & $\begin{array}{l}\text { SAND83-1646: } \\
\text { UNIAXIAL } \\
\text { COMPRESSION } \\
\text { TEST SERIES } \\
\text { ON TOPOPAH } \\
\text { SPRING TUFF } \\
\text { FROM USW GU- } \\
\text { 3, YUCCA } \\
\text { MOUNTAIN, } \\
\text { SOUTHERN }\end{array}$ & $\begin{array}{l}\text { Corroborating, } \\
\text { carried forward } \\
\text { for evaluation }\end{array}$ \\
\hline
\end{tabular}


Table 1. DTNs Containing Potentially Relevant Data for Poisson's Ratio and Young's Modulus (Continued)

\begin{tabular}{|c|c|c|c|c|c|c|}
\hline DTN & TITLE & DESCRIPTION & TYPE & \begin{tabular}{|l|} 
STATUS \\
(AT \\
START \\
OF \\
REVIEW) \\
\end{tabular} & COMMENTS & DISPOSITION \\
\hline & $\begin{array}{l}\text { ELASTIC MODEL OF } \\
\text { GU-3 760.9 SAMPLES } \\
\text { COMPRESSION } \\
\text { TEST. } \\
\\
\end{array}$ & $\begin{array}{l}\text { SAMPLES; 7) } \\
\text { EXPERIMENTAL DATA - } \\
\text { WET SAMPLES; 8) STATIC } \\
\text { MECHANICAL } \\
\text { PROPERTIES OF GU-3 } \\
\text { 760.9 SAMPLES; 9) } \\
\text { ULTRASONIC VELOCITY } \\
\text { DATA; 10) DYNAMIC } \\
\text { ELASTIC MODEL OF GU-3 } \\
\text { 760.9 SAMPLES } \\
\text { COMPRESSION TEST. }\end{array}$ & & & NEVADA. & \\
\hline SNSAND84086000.000 & $\begin{array}{l}\text { PETROLOGICAL, } \\
\text { MINERALOGICAL, } \\
\text { MECHANICAL AND } \\
\text { BULK PROPERTIES } \\
\text { OF LITHOPHYSAL } \\
\text { TUFF. }\end{array}$ & VA SUPPORTING DATA. & D & $\mathrm{U}$ & $\begin{array}{l}\text { Poisson's ratio } \\
\text { and Young's } \\
\text { Modulus data of } \\
\text { Lithophysal } \\
\text { samples taken } \\
\text { from the Topopah } \\
\text { Spring Member } \\
\end{array}$ & $\begin{array}{l}\text { Corroborating, } \\
\text { carried forward } \\
\text { for evaluation }\end{array}$ \\
\hline SNSAND84110100.000 & $\begin{array}{l}\text { UNIAXIAL AND } \\
\text { TRIAXIAL } \\
\text { COMPRESSION } \\
\text { TEST SERIES ON } \\
\text { TOPOPAH SPRING } \\
\text { TUFF FROM USW G- } \\
4 .\end{array}$ & $\begin{array}{l}\text { SAND84-1101 } \\
\text { NNA.890804.0032. VA } \\
\text { SUPPORTING DATA. }\end{array}$ & D & $U$ & $\begin{array}{l}\text { Poisson's ratio } \\
\text { and Young's } \\
\text { Modulus data of } \\
\text { Uniaxial and } \\
\text { Triaxial } \\
\text { Compression test } \\
\text { on Topopah } \\
\text { Spring Tuff from } \\
\text { USW G-4 }\end{array}$ & $\begin{array}{l}\text { Corroborating, } \\
\text { carried forward } \\
\text { for evaluation }\end{array}$ \\
\hline SNSAND85070300.000 & $\begin{array}{l}\text { UNIAXIAL AND } \\
\text { TRIAXIAL } \\
\text { COMPRESSION } \\
\text { TEST SERIES ON } \\
\text { THE TOPOPAH } \\
\text { SPRING MEMBER } \\
\text { FROM USW G-2, } \\
\text { YUCCA MOUNTAIN, } \\
\text { NEVADA. }\end{array}$ & $\begin{array}{l}\text { BULK DENSITY, GRAIN } \\
\text { DENSITY, POROSITY, } \\
\text { UNIAXIAL AND TRIAXIAL } \\
\text { COMPRESSIVE } \\
\text { STRENGTH, POISSONS } \\
\text { RATIO, AND YOUNGS } \\
\text { MODULUS DATA FROM } \\
\text { SAND85-0703. VA } \\
\text { SUPPORTING DATA. }\end{array}$ & D & $\mathrm{U}$ & $\begin{array}{l}\text { Poisson's ratio } \\
\text { and Young's } \\
\text { Modulus data } \\
\text { from compression } \\
\text { test series on the } \\
\text { Topopah Spring } \\
\text { Member from } \\
\text { USW G-2, } \\
06 / 21 / 1985 \text { to } \\
05 / 31 / 1987 \text {. }\end{array}$ & $\begin{array}{l}\text { Corroborating, } \\
\text { carried forward } \\
\text { for evaluation }\end{array}$ \\
\hline SNSAND85070900.000 & $\begin{array}{l}\text { EFFECTS OF } \\
\text { SAMPLE SIZE ON } \\
\text { THE MECHANICAL } \\
\text { BEHAVIOR OF THE } \\
\text { TOPOPAH SPRING } \\
\text { TUFF. } \\
\end{array}$ & $\begin{array}{l}\text { MECHANICAL } \\
\text { PROPERTIES DATA } \\
\text { PRESENTED IN SANDIA } \\
\text { REPORT, SAND85-0709, } \\
\text { BY R. H. PRICE (VA } \\
\text { SUPPORTING DATA) }\end{array}$ & $A$ & $\mathrm{U}$ & $\begin{array}{l}\text { Mechanical } \\
\text { Properties data } \\
\text { for samples taken } \\
\text { from Busted Butte } \\
\text { in the Topopah } \\
\text { Spring Member } \\
\end{array}$ & $\begin{array}{l}\text { Corroborating, } \\
\text { carried forward } \\
\text { for evaluation }\end{array}$ \\
\hline SNSAND85076200.000 & \begin{tabular}{|l|} 
BULK, THERMAL, \\
AND MECHANICAL \\
PROPERTIES OF \\
THE TOPOPAH \\
SPRING MEMBER OF \\
THE PAINTBRUSH \\
TUFF, YUCCA \\
MOUNTAIN, NEVADA.
\end{tabular} & $\begin{array}{l}\text { SAND85-0762. } \\
\text { NNA.871013.0012 }\end{array}$ & D & U & $\begin{array}{l}\text { Compressive } \\
\text { Strength, Young's } \\
\text { Modulus and } \\
\text { Poisson's Ratio } \\
\text { data for unit } \\
\text { TSw2 as a } \\
\text { function of } \\
\text { confining } \\
\text { pressure from } \\
\text { various sites } \\
\text { within the Yucca } \\
\text { Mountain vicinity }\end{array}$ & $\begin{array}{l}\text { Repeats or } \\
\text { Summarizes, } \\
\text { not used }\end{array}$ \\
\hline
\end{tabular}


Table 1. DTNs Containing Potentially Relevant Data for Poisson's Ratio and Young's Modulus (Continued)

\begin{tabular}{|c|c|c|c|c|c|c|}
\hline DTN & TITLE & DESCRIPTION & TYPE & $\begin{array}{l}\text { STATUS } \\
\text { (AT } \\
\text { START } \\
\text { OF } \\
\text { REVIEW) }\end{array}$ & COMMENTS & DISPOSITION \\
\hline SNSAND86101500.000 & $\begin{array}{l}\text { SUMMARY OF } \\
\text { GEOMECHANICAL } \\
\text { MEASUREMENTS } \\
\text { TAKEN IN AND } \\
\text { AROUND THE G- } \\
\text { TUNNEL } \\
\text { UNDERGROUND } \\
\text { FACILITY, NTS. }\end{array}$ & $\begin{array}{l}\text { SAND86-1015. } \\
\text { NNA.870526.0015 }\end{array}$ & D & $\mathrm{U}$ & $\begin{array}{l}\text { Summary Of } \\
\text { Geomechanical } \\
\text { Measurements } \\
\text { Taken In And } \\
\text { Around The G- } \\
\text { Tunnel } \\
\text { Underground } \\
\text { Facility, NTS }\end{array}$ & $\begin{array}{l}\text { Repeats or } \\
\text { Summarizes, } \\
\text { not used }\end{array}$ \\
\hline SNSAND86113100.000 & \begin{tabular}{|l|} 
PETROLOGIC AND \\
MECHANICAL \\
PROPERTIES OF \\
OUTCROP SAMPLES \\
OF THE WELDED, \\
DEVITRIFIED \\
TOPOPAH SPRING \\
MEMBER OF THE \\
PAINTBRUSH TUFF. \\
\end{tabular} & $\begin{array}{l}\text { SAND86-1131 BY R. H. } \\
\text { PRICE, J. R. CONNOLLY, } \\
\text { K. KEIL. HQS.880517.1704. } \\
\text { VA SUPPORTING DATA. }\end{array}$ & D & $U$ & $\begin{array}{l}\text { Poisson's ratio } \\
\text { and Young's } \\
\text { Modulus data of } \\
\text { outcrop samples } \\
\text { of the Topopah } \\
\text { Springs Member } \\
\text { on the southeast } \\
\text { flanks of Busted } \\
\text { Butte }\end{array}$ & $\begin{array}{l}\text { Corroborating, } \\
\text { carried forward } \\
\text { for evaluation }\end{array}$ \\
\hline SNSAND86713000.000 & $\begin{array}{l}\text { LABORATORY } \\
\text { DETERMINATION OF } \\
\text { THE MECHANICAL, } \\
\text { ULTRASONIC AND } \\
\text { HYDROLOGIC } \\
\text { PROPERTIES OF } \\
\text { WELDED TUFF } \\
\text { FROM THE GROUSE } \\
\text { CANYON HEATED } \\
\text { BLOCK SITE. }\end{array}$ & SAND86-7130. & D & $\mathrm{U}$ & $\begin{array}{l}\text { Poisson's ratio } \\
\text { and Young's } \\
\text { Modulus data of } \\
\text { welded tuff } \\
\text { samples from the } \\
\text { Grouse Canyon } \\
\text { Heated Block site, } \\
01 / 01 / 1986 \text { to } \\
07 / 01 / 1987 \text {. }\end{array}$ & $\begin{array}{l}\text { Not Directly } \\
\text { Related, not } \\
\text { used }\end{array}$ \\
\hline SNSAND91089400.000 & $\begin{array}{l}\text { ANISOTROPY OF } \\
\text { THE TOPOPAH } \\
\text { SPRING MEMBER } \\
\text { TUFF. }\end{array}$ & $\begin{array}{l}\text { LABORATORY DATA } \\
\text { PRESENTED IN SANDIA } \\
\text { REPORT, SAND91-0894, } \\
\text { BY R. J. MARTIN III, R. H. } \\
\text { PRICE, P. J. BOYD, R. W. } \\
\text { HAUPT }\end{array}$ & $A$ & QNV & $\begin{array}{l}\text { One table of } \\
\text { values presented. }\end{array}$ & $\begin{array}{l}\text { Status } \\
\text { changed to } \\
\text { Unqualified. } \\
\text { Corroborating, } \\
\text { carried forward } \\
\text { for evaluation } \\
\end{array}$ \\
\hline SNSAND92045000.000 & \begin{tabular}{|l|} 
ROCK MASS \\
MECHANICAL \\
PROPERTY \\
ESTIMATIONS FOR \\
THE YUCCA \\
MOUNTAIN SITE \\
CHARACTERIZATION \\
PROJECT.
\end{tabular} & SAND92-0450 & D & $\mathrm{U}$ & $\begin{array}{l}\text { ROCK MASS } \\
\text { MECHANICAL } \\
\text { PROPERTY } \\
\text { ESTIMATIONS } \\
\text { FOR THE } \\
\text { YUCCA } \\
\text { MOUNTAIN SITE } \\
\text { CHARACTERIZA } \\
\text { TION PROJECT } \\
\end{array}$ & $\begin{array}{l}\text { Repeats or } \\
\text { summarizes } \\
\text { values taken } \\
\text { from other } \\
\text { sources, not } \\
\text { used }\end{array}$ \\
\hline SNSAND92084700.000 & $\begin{array}{l}\text { THE EFFECT OF } \\
\text { FREQUENCY ON } \\
\text { YOUNG'S MODULUS } \\
\text { AND SEISMIC WAVE } \\
\text { ATTENUATION. }\end{array}$ & SAND92-0847. & D & $U$ & $\begin{array}{l}\text { Measurements of } \\
\text { cyclic loading }\end{array}$ & $\begin{array}{l}\text { Repeats or } \\
\text { summarizes, } \\
\text { not used }\end{array}$ \\
\hline
\end{tabular}


Table 1. DTNs Containing Potentially Relevant Data for Poisson's Ratio and Young's Modulus (Continued)

\begin{tabular}{|c|c|c|c|c|c|c|}
\hline DTN & TITLE & DESCRIPTION & TYPE & $\begin{array}{c}\text { STATUS } \\
\text { (AT } \\
\text { START } \\
\text { OF } \\
\text { REVIEW) }\end{array}$ & COMMENTS & DISPOSITION \\
\hline UN0110MWD027MK.001 & $\begin{array}{l}\text { LYTHOPHYSAL } \\
\text { POROSITY } \\
\text { STRESS/STRAIN } \\
\text { MODEL }\end{array}$ & $\begin{array}{l}\text { FINITE DIFFERENCE } \\
\text { ANALYSIS (USING FLAC) } \\
\text { OF THE INFLUENCE OF } \\
\text { LYTHOPHYSAL } \\
\text { POROSITY ON THE IN- } \\
\text { SITU STRESS/STRAIN } \\
\text { PROPERTIES OF } \\
\text { TOPOPAH SPRING TUFF }\end{array}$ & $A$ & Q & $\begin{array}{l}\text { Output From } \\
\text { Finite Difference } \\
\text { Analysis of The } \\
\text { Influence of } \\
\text { Lithophysal } \\
\text { Porosity on the } \\
\text { In-Situ } \\
\text { Stress/Strain } \\
\text { Properties of } \\
\text { Topopah Spring } \\
\text { Tuff }\end{array}$ & $\begin{array}{l}\text { Model } \\
\text { input/output, } \\
\text { not used }\end{array}$ \\
\hline
\end{tabular}

Table 2. DTNs That Were Qualified and Verified at the Start of the Review

\begin{tabular}{|c|c|c|}
\hline \multicolumn{3}{|c|}{ DTNs SUPPLYING QUALIFIED DATA } \\
\hline DTN & TITLE & USED IN \\
\hline SNL02030193001.001 & $\begin{array}{l}\text { MECHANICAL PROPERTIES DATA FOR } \\
\text { DRILLHOLE USW NRG-6 SAMPLES FROM } \\
\text { DEPTH } 22.2 \text { FT. TO } 328.7 \text { FT. }\end{array}$ & $\begin{array}{l}\text { ANL-MGR-GE-000003 Rev. } 00 \text { ICN } 00 \\
\text { CAL-WPS-GE-000001 Rev. } 00 \text { ICN } 00\end{array}$ \\
\hline SNL02030193001.002 & $\begin{array}{l}\text { MECHANICAL PROPERTIES DATA FOR } \\
\text { DRILLHOLE USW NRG-6 SAMPLES FROM } \\
\text { DEPTH } 22.2 \text { FT TO } 427.0 \text { FT. }\end{array}$ & $\begin{array}{l}\text { ANL-MGR-GE-000003 Rev. } 00 \text { ICN } 00 \\
\text { CAL-WPS-GE-000001 Rev. } 00 \text { ICN } 00\end{array}$ \\
\hline SNL02030193001.003 & $\begin{array}{l}\text { MECHANICAL PROPERTIES DATA FOR } \\
\text { DRILLHOLE UE-25NRG\#2 SAMPLES } \\
\text { FROM DEPTH 170.4 FT. TO 200.0 FT. }\end{array}$ & $\begin{array}{l}\text { ANL-MGR-GE-000003 Rev. } 00 \text { ICN } 00 \\
\text { CAL-WPS-GE-000001 Rev. } 00 \text { ICN } 00\end{array}$ \\
\hline SNL02030193001.004 & $\begin{array}{l}\text { MECHANICAL PROPERTIES DATA FOR } \\
\text { DRILLHOLE USW NRG-6 SAMPLES FROM } \\
\text { DEPTH 462.3 FT. TO 1085.0 FT. }\end{array}$ & $\begin{array}{l}\text { Design } \\
\text { ANL-EBS-MD-000027 Rev. } 01 \text { ICN } 01 \\
\text { ANL-MGR-GE-000003 Rev. } 00 \text { ICN } 00 \\
\text { CAL-WPS-GE-000001 Rev. } 00 \text { ICN } 00\end{array}$ \\
\hline SNL02030193001.006 & $\begin{array}{l}\text { MECHANICAL PROPERTIES DATA FOR } \\
\text { DRILL HOLE UE-25NRG\#2A SAMPLES } \\
\text { FROM DEPTH 90.0 FT. TO 254.5 FT. } \\
\end{array}$ & $\begin{array}{l}\text { ANL-MGR-GE-000003 Rev. } 00 \text { ICN } 00 \\
\text { CAL-WPS-GE-000001 Rev. } 00 \text { ICN } 00\end{array}$ \\
\hline SNL02030193001.007 & $\begin{array}{l}\text { MECHANICAL PROPERTIES DATA FOR } \\
\text { DRILL HOLE UE-25NRG\#3 SAMPLES } \\
\text { FROM DEPTH 263.3 FT. TO 265.7 FT. }\end{array}$ & $\begin{array}{l}\text { ANL-MGR-GE-000003 Rev. } 00 \text { ICN } 00 \\
\text { CAL-WPS-GE-000001 Rev. } 00 \text { ICN } 00\end{array}$ \\
\hline SNL02030193001.008 & $\begin{array}{l}\text { MECHANICAL PROPERTIES DATA FOR } \\
\text { DRILL HOLE USW NRG-6 SAMPLE } 416.0 \\
\text { FT. }\end{array}$ & $\begin{array}{l}\text { ANL-MGR-GE-000003 Rev. } 00 \text { ICN } 00 \\
\text { CAL-WPS-GE-000001 Rev. } 00 \text { ICN } 00\end{array}$ \\
\hline SNL02030193001.012 & $\begin{array}{l}\text { MECHANICAL PROPERTIES DATA FOR } \\
\text { DRILLHOLE UE25 NRG-5 SAMPLES FROM } \\
\text { DEPTH 847.2 FT. TO } 896.5 \text { FT. }\end{array}$ & $\begin{array}{l}\text { Design } \\
\text { ANL-EBS-MD-000027 Rev. } 01 \text { ICN } 01 \\
\text { ANL-MGR-GE-000003 Rev. } 00 \text { ICN } 00 \\
\text { CAL-WPS-GE-000001 Rev. } 00 \text { ICN } 00\end{array}$ \\
\hline SNL02030193001.014 & $\begin{array}{l}\text { MECHANICAL PROPERTIES DATA FOR } \\
\text { DRILLHOLE UE25 NRG-4 SAMPLES FROM } \\
\text { DEPTH 378.1 FT. TO 695.8 FT. }\end{array}$ & $\begin{array}{l}\text { ANL-MGR-GE-000003 Rev. } 00 \text { ICN } 00 \\
\text { CAL-WPS-GE-000001 Rev. } 00 \text { ICN } 00\end{array}$ \\
\hline
\end{tabular}


Table 2. DTNs That Were Qualified and Verified at the Start of the Review (Continued)

\begin{tabular}{|c|c|c|}
\hline \multicolumn{3}{|c|}{ DTNs SUPPLYING QUALIFIED DATA } \\
\hline DTN & TITLE & USED IN \\
\hline SNL02030193001.019 & $\begin{array}{l}\text { MECHANICAL PROPERTIES DATA FOR } \\
\text { DRILLHOLE USW NRG-7/7A SAMPLES } \\
\text { FROM DEPTH 507.4 FT. TO 881.0 FT. }\end{array}$ & $\begin{array}{l}\text { Design } \\
\text { ANL-EBS-MD-000027 Rev. } 01 \text { ICN } 01 \\
\text { ANL-MGR-GE-000003 Rev. } 00 \text { ICN } 00 \\
\text { CAL-WPS-GE-000001 Rev. } 00 \text { ICN } 00 \\
\end{array}$ \\
\hline SNL02030193001.020 & $\begin{array}{l}\text { MECHANICAL PROPERTIES DATA FOR } \\
\text { DRILLHOLE USW NRG-7/7A SAMPLES } \\
\text { FROM DEPTH 554.7 FT. TO 1450.1 FT. }\end{array}$ & $\begin{array}{l}\text { Design } \\
\text { ANL-EBS-MD-000027 Rev. } 01 \text { ICN } 01 \\
\text { ANL-MGR-GE-000003 Rev. } 00 \text { ICN } 00 \\
\text { CAL-WPS-GE-000001 Rev. } 00 \text { ICN } 00\end{array}$ \\
\hline SNL02030193001.021 & $\begin{array}{l}\text { MECHANICAL PROPERTIES DATA } \\
\text { (ULTRASONIC VELOCITIES, STATIC } \\
\text { ELASTIC PROPERTIES, TRIAXIAL } \\
\text { STRENGTH, DRY BULK DENSITY \& } \\
\text { POROSITY) FOR DRILLHOLE USW NRG- } \\
\text { 7/7A SAMPLES FROM DEPTH 345.0 FT. } \\
\text { TO 1408.6 FT. } \\
\end{array}$ & $\begin{array}{l}\text { Design } \\
\text { ANL-EBS-MD-000027 Rev. } 01 \text { ICN } 01 \\
\text { ANL-MGR-GE-000003 Rev. } 00 \text { ICN } 00 \\
\text { CAL-WPS-GE-000001 Rev. } 00 \text { ICN } 00\end{array}$ \\
\hline SNL02030193001.018 & $\begin{array}{l}\text { MECHANICAL PROPERTIES DATA FOR } \\
\text { DRILLHOLE USW NRG-7/7A SAMPLES } \\
\text { FROM DEPTH } 344.4 \text { FT. }\end{array}$ & $\begin{array}{l}\text { ANL-MGR-GE-000003 Rev. } 00 \text { ICN } 00 \\
\text { CAL-WPS-GE-000001 Rev. } 00 \text { ICN } 00\end{array}$ \\
\hline SNL02030193001.026 & $\begin{array}{l}\text { MECHANICAL PROPERTIES DATA } \\
\text { (ULTRASONIC VELOCITIES, ELASTIC } \\
\text { MODULI AND FRACTURE STRENGTH) } \\
\text { FOR BOREHOLE USW SD-9. } \\
\end{array}$ & $\begin{array}{l}\text { Design } \\
\text { ANL-EBS-MD-000027 Rev. } 01 \text { ICN } 01 \\
\text { ANL-MGR-GE-000003 Rev. } 00 \text { ICN } 00\end{array}$ \\
\hline SNL02030193001.028 & $\begin{array}{l}\text { CONFINED COMPRESSION } \\
\text { EXPERIMENTS AT } 150 \text { DEGREES C ON } \\
\text { TSW2 TUFF FROM BOREHOLE USW SD-9. }\end{array}$ & Design \\
\hline SNL22080196001.002 & $\begin{array}{l}\text { UNCONFINED COMPRESSION TESTS ON } \\
\text { SPECIMENS FROM THE SINGLE HEATER } \\
\text { TEST AREA IN THE THERMAL TESTING } \\
\text { FACILITY AT YUCCA MOUNTAIN, } \\
\text { NEVADA. }\end{array}$ & $\begin{array}{l}\text { Design } \\
\text { ANL-NBS-HS-000041 Rev. } 00 \text { ICN } 00\end{array}$ \\
\hline $\begin{array}{l}\text { MO0204SEPBSWHB.0 } \\
01\end{array}$ & $\begin{array}{l}\text { BOREHOLE SUSPENSION DATA FOR } \\
\text { WASTE HANDLING BUILDING SITE } \\
\text { CHARACTERIZATION AREA }\end{array}$ & $\begin{array}{l}\text { ANL-MGR-GE-000003 Rev. } 00 \text { ICN } 00 \\
\text { CAL-WPS-GE-000001 Rev. } 00 \text { ICN } 00\end{array}$ \\
\hline
\end{tabular}


Table 3. Qualified DTNs That Required Verification at the Start of the Review

\begin{tabular}{|c|c|c|}
\hline DTN & DTN TITLE & USED IN \\
\hline GS921283114220.006 & $\begin{array}{l}\text { PULSE VELOCITIES AND ULTRASONIC } \\
\text { ELASTIC CONSTANTS OF INTACT ROCK } \\
\text { CORE TEST SPECIMENS. }\end{array}$ & None \\
\hline GS921283114220.008 & $\begin{array}{l}\text { UNIAXIAL COMPRESSION AND ELASTIC } \\
\text { PROPERTIES OF INTACT ROCK CORE } \\
\text { SPECIMENS FROM UE-25 NRG\#1. } \\
\end{array}$ & None \\
\hline GS921283114220.009 & $\begin{array}{l}\text { TRIAXIAL COMPRESSION AND ELASTIC } \\
\text { PROPERTIES OF INTACT ROCK CORE TEST } \\
\text { SPECIMENS FROM UE-25 NRG\#1. }\end{array}$ & None \\
\hline GS940408312232.010 & $\begin{array}{l}\text { ELASTIC WAVE VELOCITY MEASUREMENTS } \\
\text { IN PLUG CORE SAMPLES FROM BOREHOLE } \\
\text { UE-25 UZ\#16, YUCCA MOUNTAIN, NYE } \\
\text { COUNTY, NEVADA. }\end{array}$ & Design \\
\hline LL990205304243.032 & $\begin{array}{l}\text { EFFECT OF RADIATION ON STRENGTH OF } \\
\text { TOPOPAH SPRINGS TUFF }\end{array}$ & Design \\
\hline SNL02030193001.005 & $\begin{array}{l}\text { MECHANICAL PROPERTIES DATA FOR } \\
\text { DRILLHOLE UE-25NRG\#3 SAMPLES FROM } \\
\text { DEPTH 15.4 FT. TO 297.1 FT. } \\
\end{array}$ & $\begin{array}{l}\text { ANL-MGR-GE-000003 Rev. } 00 \\
\text { ICN } 00 \text { CAL-WPS-GE-000001 } \\
\text { Rev. } 00 \text { ICN } 00\end{array}$ \\
\hline SNL02030193001.013 & $\begin{array}{l}\text { MECHANICAL PROPERTIES DATA FOR } \\
\text { DRILLHOLE UE25 NRG-2B SAMPLES FROM } \\
\text { DEPTH 2.7 FT. TO 87.6 FT. } \\
\end{array}$ & $\begin{array}{l}\text { ANL-MGR-GE-000003 Rev. } 00 \\
\text { ICN } 00 \text { CAL-WPS-GE-000001 } \\
\text { Rev. } 00 \text { ICN } 00\end{array}$ \\
\hline SNL02030193001.015 & $\begin{array}{l}\text { MECHANICAL PROPERTIES DATA FOR } \\
\text { DRILLHOLE UE25 NR G-4 SAMPLES FROM } \\
\text { DEPTH 527.0 FT. } \\
\end{array}$ & $\begin{array}{l}\text { ANL-MGR-GE-000003 Rev. } 00 \\
\text { ICN } 00 \text { CAL-WPS-GE-000001 } \\
\text { Rev. } 00 \text { ICN } 00\end{array}$ \\
\hline SNL02030193001.016 & $\begin{array}{l}\text { MECHANICAL PROPERTIES DATA FOR } \\
\text { DRILLHOLE USW NRG-7/7A SAMPLES FROM } \\
\text { DEPTH 18.0 FT TO 472.9 FT. } \\
\end{array}$ & $\begin{array}{l}\text { ANL-MGR-GE-000003 Rev. } 00 \\
\text { ICN } 00 \text { CAL-WPS-GE-000001 } \\
\text { Rev. } 00 \text { ICN } 00\end{array}$ \\
\hline SNL02040687004.001 & $\begin{array}{l}\text { CREEP IN TOPOPAH SPRING MEMBER } \\
\text { WELDED TUFF }\end{array}$ & Design \\
\hline SNL02100196001.001 & $\begin{array}{l}\text { UNCONFINED COMPRESSION TESTS ON } \\
\text { SPECIMENS FROM THE DRIFT SCALE TEST } \\
\text { AREA OF THE EXPLORATORY STUDIES } \\
\text { FACILITY AT YUCCA MOUNTAIN, NEVADA. } \\
\end{array}$ & $\begin{array}{l}\text { Design } \\
\text { ANL-NBS-HS-000041 Rev. } 00 \text { ICN } \\
00\end{array}$ \\
\hline SNL22080196001.003 & $\begin{array}{l}\text { POSTTEST LABORATORY THERMAL AND } \\
\text { MECHANICAL CHARACTERIZATION FOR } \\
\text { SINGLE HEATER TEST (SHT) BLOCK. } \\
\end{array}$ & $\begin{array}{l}\text { ANL-NBS-HS-000041 Rev. } 00 \text { ICN } \\
00 \text { BAB000000-01717-5700-00005 } \\
\text { Rev. } 00 \text { ICN } 01\end{array}$ \\
\hline SNSAND 91089400.000 & $\begin{array}{l}\text { ANISOTROPY OF THE TOPOPAH SPRING } \\
\text { MEMBER TUFF. }\end{array}$ & Design \\
\hline
\end{tabular}


Table 4. DTNs that Required Qualification at the Start of the Review

\begin{tabular}{|c|c|c|}
\hline DTN & DTN TITLE & USED IN \\
\hline SN0108SD821723.001 & $\begin{array}{l}\text { UNIAXIAL AND TRIAXIAL COMPRESSION TEST DATA ON } \\
\text { SAMPLES FROM USW G-1 }\end{array}$ & Design \\
\hline SNL02030180001.001 & $\begin{array}{l}\text { MATRIX COMPRESSIVE TESTS TO CHARACTERIZE TUFFS } \\
\text { FROM UE-25A\#1 AND THE LASER DRIFT IN G-TUNNEL. }\end{array}$ & None \\
\hline SNL02040687003.001 & $\begin{array}{l}\text { MECHANICAL PROPERTY DATA TO ANALYZE THE } \\
\text { RESPONSE OF SAMPLES OF UNIT TSW2 TO HIGH } \\
\text { TEMPERATURE AND/OR LOW STRAIN RATES. }\end{array}$ & Design \\
\hline SNL02033084002.001 & $\begin{array}{l}\text { PARAMETER EFFECTS ON MATRIX COMPRESSIVE } \\
\text { PROPERTIES OF THE TOPOPAH SPRING MEMBER AT } \\
\text { BUSTED BUTTE. }\end{array}$ & None \\
\hline SNL02072983001.001 & $\begin{array}{l}\text { LABORATORY COMPARISON OF MECHANICAL } \\
\text { COMPRESSIVE DATA FROM MATRIX COMPRESSIVE TESTS } \\
\text { USING BUSTED BUTTE OUTCROP SAMPLES. }\end{array}$ & Design \\
\hline SNL02072983003.001 & $\begin{array}{l}\text { LABORATORY COMPARISON OF MECHANICAL } \\
\text { COMPRESSIVE DATA FROM MATRIX COMPRESSIVE TESTS } \\
\text { USING THE BUSTED BUTTE OUTCROP SAMPLES. }\end{array}$ & Design \\
\hline SNSAND80145300.000 & $\begin{array}{l}\text { ROCK MECHANICS PROPERTIES OF VOLCANIC TUFFS } \\
\text { FROM THE NEVADA TEST SITE. }\end{array}$ & Design \\
\hline SNSAND81166400.000 & $\begin{array}{l}\text { EFFECTS OF ELEVATED TEMPERATURE AND PORE } \\
\text { PRESSURE ON THE MECHANICAL BEHAVIOR OF } \\
\text { BULLFROG TUFF. }\end{array}$ & Design \\
\hline SNSAND82048100.000 & $\begin{array}{l}\text { UNIAXIAL COMPRESSION TEST SERIES ON BULLFROG } \\
\text { TUFF. }\end{array}$ & None \\
\hline SNSAND 82105500.000 & UNIAXIAL COMPRESSION TEST SERIES ON TRAM TUFF. & None \\
\hline SNSAND82131400.000 & $\begin{array}{l}\text { UNIAXIAL AND TRIAXIAL COMPRESSION TEST SERIES ON } \\
\text { CALICO HILLS TUFF. }\end{array}$ & None \\
\hline SNSAND83164600.000 & $\begin{array}{l}\text { EXPERIMENTAL DATA OF FULLY SATURATED AND WET } \\
\text { SAMPLES; STATIC MECHANICAL PROPERTIES OF GU-3 } \\
\text { 760.9 SAMPLES; ULTRASONIC VELOCITY DATA; AND } \\
\text { DYNAMIC ELASTIC MODEL OF GU-3 760.9 SAMPLES } \\
\text { COMPRESSION TEST. }\end{array}$ & None \\
\hline SNSAND84086000.000 & $\begin{array}{l}\text { PETROLOGICAL, MINERALOGICAL, MECHANICAL AND BULK } \\
\text { PROPERTIES OF LITHOPHYSAL TUFF. }\end{array}$ & Design \\
\hline SNSAND84110100.000 & $\begin{array}{l}\text { UNIAXIAL AND TRIAXIAL COMPRESSION TEST SERIES ON } \\
\text { TOPOPAH SPRING TUFF FROM USW G-4, YUCCA } \\
\text { MOUNTAIN, NEVADA. }\end{array}$ & Design \\
\hline SNSAND85070300.000 & $\begin{array}{l}\text { UNIAXIAL AND TRIAXIAL COMPRESSION TEST SERIES ON } \\
\text { THE TOPOPAH SPRING MEMBER FROM USW G-2, YUCCA } \\
\text { MOUNTAIN, NEVADA. }\end{array}$ & Design \\
\hline SNSAND85070900.000 & $\begin{array}{l}\text { EFFECTS OF SAMPLE SIZE ON THE MECHANICAL } \\
\text { BEHAVIOR OF THE TOPOPAH SPRING TUFF. } \\
\end{array}$ & Design \\
\hline SNSAND86113100.000 & $\begin{array}{l}\text { PETROLOGIC AND MECHANICAL PROPERTIES OF } \\
\text { OUTCROP SAMPLES OF THE WELDED, DEVITRIFIED } \\
\text { TOPOPAH SPRING MEMBER OF THE PAINTBRUSH TUFF. }\end{array}$ & Design \\
\hline
\end{tabular}


Table 5. Summary of Static Test Results for Poisson's Ratio under Saturated and Ambient Conditions

\begin{tabular}{|c|c|c|c|c|c|c|c|c|}
\hline Formation & $\begin{array}{l}\text { Litho- } \\
\text { strati- } \\
\text { graphic } \\
\text { Unit }\end{array}$ & $\begin{array}{l}\text { Saturation } \\
\text { Condition }\end{array}$ & $\begin{array}{c}\text { Number of } \\
\text { Tests }\end{array}$ & $\begin{array}{l}\text { Mean } \\
\text { Value }\end{array}$ & $\begin{array}{l}\text { Standard } \\
\text { Deviation }\end{array}$ & $\begin{array}{c}\text { Median } \\
\text { Value }\end{array}$ & $\begin{array}{c}\text { Minimum } \\
\text { Value }\end{array}$ & $\begin{array}{l}\text { Maximum } \\
\text { Value }\end{array}$ \\
\hline \multirow[t]{3}{*}{ Tmr } & & Sat. & 5 & 0.034 & 0.025 & 0.02 & 0.01 & 0.07 \\
\hline & Tpki & Sat. & 7 & 0.187 & 0.137 & 0.15 & 0.05 & 0.48 \\
\hline & Tpbt5 & - & - & - & - & - & - & - \\
\hline \multirow[t]{14}{*}{ Tpc } & Tpcrv & - & - & - & - & - & - & - \\
\hline & Tpcrn & Sat. & 17 & 0.204 & 0.034 & 0.20 & 0.15 & 0.29 \\
\hline & & Ambient & 3 & 0.163 & 0.015 & 0.16 & 0.15 & 0.18 \\
\hline & Tpcrl & - & - & - & - & - & - & - \\
\hline & Tpcpul & Sat. & 5 & 0.186 & 0.021 & 0.20 & 0.15 & 0.20 \\
\hline & & Ambient & 4 & 0.165 & 0.019 & 0.16 & 0.15 & 0.19 \\
\hline & Tpcpmn & Sat. & 18 & 0.199 & 0.037 & 0.20 & 0.12 & 0.29 \\
\hline & & Ambient & 3 & 0.176 & 0.005 & 0.18 & 0.17 & 0.18 \\
\hline & Tpcpll & Sat. & 19 & 0.206 & 0.050 & 0.22 & 0.07 & 0.32 \\
\hline & Tpcpln & Sat. & 27 & 0.205 & 0.023 & 0.21 & 0.16 & 0.26 \\
\hline & Tpcpv2 & Sat. & 5 & 0.120 & 0.048 & 0.13 & 0.06 & 0.19 \\
\hline & Tpcpv1 & Sat. & 4 & 0.100 & 0.078 & 0.08 & 0.03 & 0.21 \\
\hline & Tpbt4 & Sat. & 1 & 0.170 & - & - & - & - \\
\hline & & Ambient & 1 & 0.160 & - & - & - & - \\
\hline \multirow[t]{3}{*}{ Tpy } & & Sat. & 5 & 0.156 & 0.008 & 0.15 & 0.15 & 0.17 \\
\hline & Tpbt3 & Sat. & 1 & 0.280 & - & - & - & - \\
\hline & & Ambient & 1 & 0.165 & - & - & - & - \\
\hline \multirow[t]{3}{*}{ Tpp } & & Sat. & 10 & 0.284 & 0.123 & 0.27 & 0.09 & 0.53 \\
\hline & & Ambient & 2 & 0.285 & 0.077 & 0.29 & 0.23 & 0.34 \\
\hline & Tpbt2 & Sat. & 6 & 0.208 & 0.102 & 0.17 & 0.13 & 0.40 \\
\hline \multirow[t]{9}{*}{ Tpt } & Tptrv & - & - & - & - & - & - & - \\
\hline & Tptrn & Sat. & 93 & 0.227 & 0.065 & 0.21 & 0.02 & 0.45 \\
\hline & & Ambient & 8 & 0.213 & 0.060 & 0.21 & 0.13 & 0.30 \\
\hline & Tptrl & Sat. & 4 & 0.367 & 0.155 & 0.30 & 0.28 & 0.60 \\
\hline & Tptpul & Sat. & 12 & 0.242 & 0.127 & 0.21 & 0.09 & 0.46 \\
\hline & Tptpmn & Sat. & 76 & 0.209 & 0.039 & 0.21 & 0.10 & 0.33 \\
\hline & & Ambient & 55 & 0.186 & 0.043 & 0.18 & 0.12 & 0.39 \\
\hline & Tptpll & Sat. & 41 & 0.217 & 0.070 & 0.20 & 0.11 & 0.40 \\
\hline & Tptpln & Sat. & 39 & 0.228 & 0.040 & 0.23 & 0.12 & 0.31 \\
\hline
\end{tabular}


Table 5. Summary of Static Test Results for Poisson's Ratio under Saturated and Ambient Conditions (Continued)

\begin{tabular}{|c|c|c|c|c|c|c|c|c|}
\hline Formation & $\begin{array}{l}\text { Litho- } \\
\text { strati- } \\
\text { graphic } \\
\text { Unit }\end{array}$ & $\begin{array}{l}\text { Saturation } \\
\text { Condition }\end{array}$ & $\begin{array}{c}\text { Number of } \\
\text { Tests }\end{array}$ & $\begin{array}{l}\text { Mean } \\
\text { Value }\end{array}$ & $\begin{array}{l}\text { Standard } \\
\text { Deviation }\end{array}$ & $\begin{array}{c}\text { Median } \\
\text { Value }\end{array}$ & $\begin{array}{l}\text { Minimum } \\
\text { Value }\end{array}$ & $\begin{array}{l}\text { Maximum } \\
\text { Value }\end{array}$ \\
\hline & & Ambient & 3 & 0.246 & 0.047 & 0.23 & 0.21 & 0.30 \\
\hline & Tptpv3 & Sat. & 8 & 0.226 & 0.090 & 0.18 & 0.15 & 0.39 \\
\hline & Tptpv2 & Sat. & 3 & 0.203 & 0.020 & 0.21 & 0.18 & 0.22 \\
\hline \multirow[t]{5}{*}{ Tac } & & Sat. & 23 & 0.264 & 0.082 & 0.26 & 0.09 & 0.45 \\
\hline & & Ambient & 9 & 0.248 & 0.053 & 0.27 & 0.14 & 0.31 \\
\hline & Tacbt & Sat. & 4 & 0.325 & 0.042 & 0.33 & 0.27 & 0.37 \\
\hline & Tcprn & Ambient & 3 & 0.216 & 0.028 & 0.20 & 0.20 & 0.25 \\
\hline & Tcplc & Ambient & 1 & 0.300 & - & - & - & - \\
\hline \multirow[t]{4}{*}{ Tсp } & Tcplv & Ambient & 1 & 0.180 & - & - & - & - \\
\hline & Tcpbt & Sat. & 1 & 0.110 & - & - & - & - \\
\hline & Tcbuv & Sat. & 3 & 0.116 & 0.005 & 0.12 & 0.11 & 0.12 \\
\hline & Tcbuc & Sat. & 4 & 0.142 & 0.023 & 0.15 & 0.11 & 0.16 \\
\hline \multirow[t]{7}{*}{$\mathrm{Tcb}$} & & Ambient & 1 & 0.190 & - & - & - & - \\
\hline & Tcbm & Sat. & 1 & 0.140 & - & - & - & - \\
\hline & & Ambient & 3 & 0.186 & 0.120 & 0.23 & 0.05 & 0.28 \\
\hline & Tcblv & Sat. & 4 & 0.120 & 0.028 & 0.13 & 0.08 & 0.14 \\
\hline & Tcbbt & Sat. & 2 & 0.135 & 0.007 & 0.16 & 0.13 & 0.14 \\
\hline & Tctrn & Sat. & 2 & 0.255 & 0.021 & 0.26 & 0.24 & 0.27 \\
\hline & Tctuc & Sat. & 2 & 0.345 & 0.049 & 0.35 & 0.31 & 0.38 \\
\hline \multirow[t]{3}{*}{ Tct } & Tctuv & Sat. & 3 & 0.160 & 0.020 & 0.16 & 0.14 & 0.18 \\
\hline & Tctlc & Sat. & 1 & 0.230 & - & - & - & - \\
\hline & Tctlv & Sat. & 10 & 0.223 & 0.078 & 0.23 & 0.09 & 0.31 \\
\hline
\end{tabular}


Table 6. Summary of Static Test Results for Young's Modulus under Saturated and Ambient Conditions

\begin{tabular}{|c|c|c|c|c|c|c|c|c|}
\hline Formation & $\begin{array}{l}\text { Litho- } \\
\text { strati- } \\
\text { graphic } \\
\text { Unit }\end{array}$ & $\begin{array}{l}\text { Saturation } \\
\text { Condition }\end{array}$ & $\begin{array}{c}\text { Number of } \\
\text { Tests }\end{array}$ & $\begin{array}{l}\text { Mean } \\
\text { Value } \\
\text { (GPa) }\end{array}$ & $\begin{array}{l}\text { Standard } \\
\text { Deviation }\end{array}$ & $\begin{array}{l}\text { Median } \\
\text { Value } \\
(\mathrm{GPa})\end{array}$ & $\begin{array}{l}\text { Minimum } \\
\text { Value } \\
\text { (GPa) }\end{array}$ & $\begin{array}{l}\text { Maximum } \\
\text { Value } \\
\text { (GPa) }\end{array}$ \\
\hline \multirow[t]{3}{*}{ Tmr } & & Sat. & 12 & 3.60 & 1.99 & 3.85 & 0.70 & 7.20 \\
\hline & Tpki & - & - & - & - & - & - & - \\
\hline & Tpbt5 & - & - & - & - & - & - & - \\
\hline \multirow[t]{15}{*}{$\mathrm{Tpc}$} & Tpcrv & - & - & - & - & - & - & - \\
\hline & Tpcrn & Sat. & 17 & 15.16 & 8.38 & 12.60 & 6.50 & 38.20 \\
\hline & Tpcrl & - & - & - & - & - & - & - \\
\hline & & & & & & & & \\
\hline & Tpcpul & Sat. & 5 & 23.72 & 6.89 & 27.00 & 14.80 & 29.60 \\
\hline & & Ambient & 16 & 22.24 & 2.57 & 22.51 & 16.62 & 25.72 \\
\hline & Tpcpmn & Sat. & 19 & 35.56 & 6.10 & 37.40 & 20.00 & 42.90 \\
\hline & & Ambient & 14 & 31.31 & 4.46 & 31.78 & 19.51 & 37.16 \\
\hline & Tpcpll & Sat. & 8 & 30.96 & 6.52 & 31.90 & 22.30 & 39.00 \\
\hline & Tpcpln & Sat. & 27 & 34.28 & 7.65 & 36.50 & 18.80 & 54.00 \\
\hline & Tpcpv3 & Sat. & 1 & 2.10 & - & - & - & - \\
\hline & Tpcpv2 & Sat. & 4 & 13.10 & 8.21 & 11.25 & 5.90 & 24.00 \\
\hline & Tpcpv1 & Sat. & 3 & 3.26 & 0.92 & 3.70 & 2.20 & 3.90 \\
\hline & Tpbt4 & Ambient & 1 & 2.90 & - & - & - & - \\
\hline & & Sat. & 2 & 0.25 & 0.07 & 0.25 & 0.20 & 0.30 \\
\hline \multirow[t]{3}{*}{ Tpy } & & Sat. & 5 & 5.24 & 3.04 & 4.90 & 2.30 & 9.20 \\
\hline & Tpbt3 & Sat. & 2 & 1.30 & 1.55 & 1.30 & 0.20 & 2.40 \\
\hline & & Ambient & 2 & 1.80 & 0.84 & 1.80 & 1.20 & 2.40 \\
\hline \multirow[t]{4}{*}{ Tpp } & & Sat. & 10 & 0.98 & 0.66 & 0.75 & 0.30 & 2.10 \\
\hline & & Ambient & 3 & 1.20 & 0.36 & 1.30 & 0.80 & 1.50 \\
\hline & Tpbt2 & Sat. & 6 & 0.66 & 0.68 & 0.50 & 0.01 & 1.70 \\
\hline & & Ambient & 2 & 0.60 & 0.14 & 0.60 & 0.50 & 0.70 \\
\hline \multirow[t]{7}{*}{ Tpt } & - & - & - & - & - & - & - & - \\
\hline & Tptrv3 & Sat. & 2 & 0.99 & 1.29 & 0.98 & 0.07 & 1.90 \\
\hline & Tptrn & Sat. & 103 & 20.41 & 5.95 & 20.60 & 2.00 & 34.30 \\
\hline & Tptrl & Sat. & 4 & 10.45 & 3.27 & 10.50 & 6.40 & 14.40 \\
\hline & Tptpul & Sat. & 14 & 20.76 & 7.68 & 20.40 & 6.00 & 33.30 \\
\hline & Tptpmn & Sat. & 84 & 33.31 & 4.98 & 34.00 & 13.40 & 43.60 \\
\hline & & Ambient & 55 & 33.86 & 4.36 & 34.30 & 20.10 & 43.10 \\
\hline
\end{tabular}


Table 6. Summary of Static Test Results for Young's Modulus under Saturated and Ambient Conditions (Continued)

\begin{tabular}{|l|l|l|c|c|c|c|c|c|}
\hline Formation & $\begin{array}{c}\text { Litho- } \\
\text { strati- } \\
\text { graphic } \\
\text { Unit }\end{array}$ & $\begin{array}{c}\text { Saturation } \\
\text { Condition }\end{array}$ & $\begin{array}{c}\text { Number of } \\
\text { Tests }\end{array}$ & $\begin{array}{c}\text { Mean } \\
\text { Value } \\
(\mathbf{G P a})\end{array}$ & $\begin{array}{c}\text { Standard } \\
\text { Deviation }\end{array}$ & $\begin{array}{c}\text { Median } \\
\text { Value } \\
\text { (GPa) }\end{array}$ & $\begin{array}{c}\text { Minimum } \\
\text { Value } \\
\text { (GPa) }\end{array}$ & $\begin{array}{c}\text { Maximum } \\
\text { Value } \\
\text { (GPa) }\end{array}$ \\
\hline & Tptpll & Sat. & 46 & 27.45 & 7.28 & 27.10 & 2.44 & 38.10 \\
\hline & Tptpln & Sat. & 39 & 33.72 & 6.40 & 35.30 & 16.60 & 44.40 \\
\hline & Tptpv3 & Sat. & 5 & 36.16 & 10.89 & 32.90 & 25.20 & 54.20 \\
\hline & Tptpv2 & Sat. & 3 & 16.53 & 0.37 & 16.70 & 16.10 & 16.80 \\
\hline Tac & & Sat. & 11 & 6.42 & 1.29 & 6.30 & 3.87 & 8.79 \\
\hline & & Ambient & 6 & 9.94 & 2.65 & 9.03 & 7.29 & 14.02 \\
\hline & Tacbt & Sat. & 4 & 5.41 & 3.31 & 5.34 & 2.52 & 8.41 \\
\hline Tcp & Tcprn & Ambient & 3 & 26.65 & 4.53 & 27.01 & 21.95 & 31.00 \\
\hline & Tcplv & Ambient & 1 & 7.84 & - & - & - & - \\
\hline Tmr & & Sat. & 12 & 3.60 & 1.99 & 3.85 & 0.70 & 7.20 \\
\hline & Tcpbt & - & - & - & - & - & - & - \\
\hline Tcb & & Sat. & 4 & 18.40 & 7.29 & 15.80 & 13.10 & 28.90 \\
\hline & & Ambient & 4 & 17.57 & 2.09 & 17.05 & 15.70 & 20.50 \\
\hline & Tcbuv & Sat. & 4 & 8.36 & 6.00 & 7.82 & 2.03 & 15.80 \\
\hline & Tcbuc & Sat. & 2 & 7.63 & 1.05 & 7.63 & 6.88 & 8.38 \\
\hline & Tcbm & Sat. & 1 & 12.60 & - & - & - & - \\
\hline & & Ambient & 3 & 15.90 & 8.37 & 19.24 & 6.37 & 22.10 \\
\hline & Tcblv & Sat. & 2 & 18.67 & 4.56 & 18.67 & 15.45 & 21.90 \\
\hline & Tcbbt & Sat. & 2 & 18.90 & 0.70 & 18.90 & 18.40 & 19.40 \\
\hline & Tctrn & - & - & - & - & - & - & - \\
\hline & Tctuc & Sat. & 1 & 14.70 & - & - & - & - \\
\hline & Tctuv & Sat. & 3 & 12.73 & 2.10 & 13.30 & 10.40 & 14.50 \\
\hline & Tctlc & Sat. & 1 & 20.70 & - & - & - & - \\
\hline & Tctlv & Sat. & 17 & 8.09 & 2.35 & 8.26 & 5.17 & 13.40 \\
\hline
\end{tabular}

Table 7. Summary of Static Young's Modulus Results (GPa) from Saturated Tptpul Samples by Location

\begin{tabular}{|l|c|c|c|c|}
\hline & All values & Borehole values & Busted Butte & $\begin{array}{c}\text { Borehole Values } \\
\text { with One Busted } \\
\text { Butte Value Used }\end{array}$ \\
\hline Mean & 18.69 & 21.16 & 15.47 & 20.76 \\
\hline Median & 17.80 & 21.10 & 15.80 & 20.40 \\
\hline Standard Deviation & 6.78 & 7.84 & 3.15 & 7.68 \\
\hline Range & 27.30 & 27.30 & 10.60 & 27.30 \\
\hline Minimum & 6.00 & 6.00 & 10.9 & 6.00 \\
\hline Maximum & 33.30 & 33.30 & 21.50 & 33.30 \\
\hline Count & 23 & 13 & 10 & 14 \\
\hline
\end{tabular}


Table 8. Summary of Static Young's Modulus Results (GPa) from Saturated Tptpmn Samples by Location

\begin{tabular}{|l|c|c|c|c|}
\hline & All values & Borehole values & Busted Butte & $\begin{array}{c}\text { Borehole Values } \\
\text { with One Busted } \\
\text { Butte Value Used }\end{array}$ \\
\hline Mean & 34.22 & 33.28 & 35.40 & 33.31 \\
\hline Median & 34.17 & 34.00 & 35.05 & 34.00 \\
\hline Standard Deviation & 5.93 & 5.01 & 6.78 & 4.98 \\
\hline Range & 33.90 & 30.20 & 28.70 & 30.20 \\
\hline Minimum & 13.40 & 13.40 & 18.60 & 13.40 \\
\hline Maximum & 47.30 & 43.60 & 47.30 & 43.60 \\
\hline Count & 149 & 83 & 66 & 84 \\
\hline
\end{tabular}

Table 9. Summary of Static Test Results for Young's Modulus (GPa) under Room Temperature and Increasing Confining Pressure Conditions

\begin{tabular}{|l|c|c|c|}
\hline & $\begin{array}{c}\text { Room Temperature, } \\
\text { Saturated, Atmospheric } \\
\text { Confining Pressure }\end{array}$ & $\begin{array}{c}\text { Room Temperature, } \\
\text { Saturated, 5 MPa } \\
\text { Confining Pressure }\end{array}$ & $\begin{array}{c}\text { Room Temperature, } \\
\text { Saturated, 10 MPa } \\
\text { Confining Pressure }\end{array}$ \\
\hline Mean & 33.66 & 36.04 & 31.58 \\
\hline Median & 34.45 & 34.50 & 34.00 \\
\hline $\begin{array}{l}\text { Standard } \\
\text { Deviation }\end{array}$ & 5.48 & 3.47 & 5.50 \\
\hline Minimum & 13.40 & 33.90 & 21.40 \\
\hline Maximum & 40.70 & 43.60 & 38.00 \\
\hline Count & 48 & 7 & 9 \\
\hline
\end{tabular}

Table 10. Summary of Static Test Results for Young's Modulus under High Temperature (T150) and Increasing Confining Pressure Conditions.

\begin{tabular}{|l|c|c|c|c|}
\hline & $\begin{array}{c}\text { T150 C, Saturated, } \\
\text { Atmospheric Confining } \\
\text { Pressure }\end{array}$ & $\begin{array}{c}\text { T150 C, Saturated, } \\
\text { 5 MPa Confining } \\
\text { Pressure }\end{array}$ & $\begin{array}{c}\text { T150 C, Saturated, } \\
\text { 10 MPa Confining } \\
\text { Pressure }\end{array}$ & $\begin{array}{c}\text { T150 C, Saturated, } \\
\text { 15 MPa Confining } \\
\text { Pressure }\end{array}$ \\
\hline Mean & 35.04 & 31.37 & 32.70 & 31.50 \\
\hline Median & 37.95 & 32.25 & 33.50 & 31.00 \\
\hline $\begin{array}{l}\text { Standard } \\
\text { Deviation }\end{array}$ & 6.85 & 6.99 & 4.63 & 3.02 \\
\hline Minimum & 14.00 & 16.00 & 22.30 & 27.70 \\
\hline Maximum & 42.00 & 39.90 & 37.50 & 34.60 \\
\hline Count & 16 & 8 & 9 & 5 \\
\hline
\end{tabular}

Note: Includes data from Senseny and Mellegard (1987) 
Table 11. Summary of Static Test Results from Variation in Sample Size on Intact Cylindrical Samples of the Topopah Spring Member From Busted Butte.

\begin{tabular}{|c|c|c|c|c|c|}
\hline $\begin{array}{c}\text { Diameter } \\
(\mathbf{m m})\end{array}$ & $\begin{array}{c}\text { Young's Modulus } \\
\text { (GPa) }\end{array}$ & Poisson's Ratio & $\begin{array}{c}\text { Ultimate Strength } \\
\text { (MPa) }\end{array}$ & $\begin{array}{c}\text { Axial Strain } \\
\text { (milli) }\end{array}$ & Count \\
\hline 25.4 & $43.7 \pm 4.7$ & $0.19 \pm 0.03$ & $193.8 \pm 61.8$ & $4.9 \pm 0.9$ & 6 \\
\hline 50.8 & $37.1 \pm 4.3$ & $0.21 \pm 0.01$ & $140.8 \pm 35.4$ & $4.1 \pm 0.6$ & 6 \\
\hline 82.6 & $41.5 \pm 4.4$ & $0.22 \pm 0.02$ & $119.6 \pm 31.7$ & $3.5 \pm 0.4$ & 9 \\
\hline 127.0 & $35.3 \pm 5.6$ & $0.21 \pm 0.03$ & $97.7 \pm 30.6$ & $3.3 \pm 0.5$ & 11 \\
\hline 228.6 & $39.7 \pm 3.3$ & $0.21 \pm 0.00$ & $90.1 \pm 4.6$ & $2.7 \pm 0.4$ & 2 \\
\hline
\end{tabular}

Note: Each value is the mean \pm one standard deviation

Table 12. Summary of Dynamic Test Results for Poisson's Ratio from Shear Wave Measurements under Dry and Wet Conditions

\begin{tabular}{|c|c|c|c|c|c|c|c|c|}
\hline Formation & $\begin{array}{l}\text { Litho- } \\
\text { strati- } \\
\text { graphic } \\
\text { Unit }\end{array}$ & $\begin{array}{l}\text { Saturation } \\
\text { Condition }\end{array}$ & $\begin{array}{c}\text { Number of } \\
\text { Tests }\end{array}$ & $\begin{array}{l}\text { Mean } \\
\text { Value } \\
(\mathrm{GPa})\end{array}$ & $\begin{array}{l}\text { Standard } \\
\text { Deviation }\end{array}$ & $\begin{array}{c}\text { Median } \\
\text { Value } \\
(\mathrm{GPa})\end{array}$ & $\begin{array}{l}\text { Minimum } \\
\text { Value } \\
\text { (GPa) }\end{array}$ & $\begin{array}{l}\text { Maximum } \\
\text { Value } \\
\text { (GPa) }\end{array}$ \\
\hline \multirow[t]{7}{*}{ Tpc } & Tpcrn & Dry & 6 & 0.341 & 0.014 & 0.345 & 0.32 & 0.36 \\
\hline & Tpcpul & Dry & 16 & 0.322 & 0.034 & 0.32 & 0.27 & 0.38 \\
\hline & Tpcpmn & Dry & 14 & 0.292 & 0.030 & 0.285 & 0.24 & 0.35 \\
\hline & Tpcpll & Dry & 1 & 0.05 & - & - & - & - \\
\hline & Tpcpln & Dry & 3 & 0.135 & 0.011 & 0.13 & 0.127 & 0.149 \\
\hline & Tpcpv & - & - & - & - & - & - & - \\
\hline & Tpbt4 & Dry & 1 & 0.15 & - & - & - & - \\
\hline \multirow[t]{2}{*}{ Tpy } & & Dry & 1 & 0.15 & - & - & - & - \\
\hline & Tpbt3 & Dry & 1 & 0.19 & - & - & - & - \\
\hline \multirow[t]{2}{*}{ Tpp } & & - & - & - & - & - & - & - \\
\hline & Tpbt2 & Dry. & 1 & 0.30 & - & - & - & - \\
\hline \multirow[t]{11}{*}{ Tpt } & & - & - & - & - & - & - & - \\
\hline & Tptrv2 & Dry & 1 & 0.09 & - & - & - & - \\
\hline & Tptrn & Dry & 5 & 0.17 & 0.037 & 0.182 & 0.123 & 0.207 \\
\hline & Tptrl & - & - & - & - & - & - & - \\
\hline & Tptpul & Dry & 6 & 0.112 & 0.064 & 0.104 & 0.015 & 0.189 \\
\hline & Tptpmn & Dry & 10 & 0.195 & 0.037 & 0.21 & 0.124 & 0.238 \\
\hline & & Sat & 36 & 0.222 & 0.020 & 0.225 & 0.180 & 0.280 \\
\hline & Tptpll & Dry & 5 & 0.101 & 0.071 & 0.112 & 0.021 & 0.199 \\
\hline & Tptpln & Dry & 4 & 0.142 & 0.012 & 0.141 & 0.132 & 0.155 \\
\hline & Tptpv3 & Dry & 1 & 0.18 & - & - & - & - \\
\hline & Tptpv1 & Dry & 1 & 0.07 & - & - & - & - \\
\hline \multirow[t]{2}{*}{ Tac } & & Dry & 7 & 0.13 & 0.028 & 0.129 & 0.098 & 0.175 \\
\hline & Tacbt & Dry & 1 & 0.04 & - & - & - & - \\
\hline \multirow[t]{2}{*}{ Tcp } & & Dry & 10 & 0.183 & 0.149 & 0.177 & -0.159 & 0.221 \\
\hline & & Sat & 4 & 0.317 & 0.041 & 0.31 & 0.28 & 0.37 \\
\hline
\end{tabular}

Note: Test conditions were at Room Temperature and Confining Pressure varied from atmospheric to $0.7 \mathrm{MPa}$ 
Table 13. Summary of Dynamic Test Results for Young's Modulus from Shear Wave Measurements under Dry and Wet Conditions

\begin{tabular}{|c|c|c|c|c|c|c|c|c|}
\hline Formation & $\begin{array}{l}\text { Litho- } \\
\text { strati- } \\
\text { graphic } \\
\text { Unit }\end{array}$ & $\begin{array}{l}\text { Saturation } \\
\text { Condition }\end{array}$ & $\begin{array}{c}\text { Number of } \\
\text { Tests }\end{array}$ & $\begin{array}{l}\text { Mean } \\
\text { Value } \\
\text { (GPa) }\end{array}$ & $\begin{array}{l}\text { Standard } \\
\text { Deviation }\end{array}$ & $\begin{array}{c}\text { Median } \\
\text { Value } \\
(\mathrm{GPa})\end{array}$ & $\begin{array}{l}\text { Minimum } \\
\text { Value } \\
\text { (GPa) }\end{array}$ & $\begin{array}{l}\text { Maximum } \\
\text { Value } \\
\text { (GPa) }\end{array}$ \\
\hline \multirow[t]{7}{*}{ Tpc } & Tpcrn & Dry & 6 & 20.09 & 2.00 & 19.51 & 17.93 & 22.75 \\
\hline & Tpcpul & Dry & 16 & 22.24 & 2.57 & 22.51 & 16.62 & 25.72 \\
\hline & Tpcpmn & Dry & 14 & 31.31 & 4.46 & 31.75 & 19.51 & 37.16 \\
\hline & Tpcpll & Dry & 1 & 43.10 & - & - & - & - \\
\hline & Tpcpln & Dry & 3 & 42 & 2.85 & 43.6 & 38.7 & 43.7 \\
\hline & Tpcpv & - & - & - & - & - & - & - \\
\hline & Tpbt4 & Dry & 2 & 2.95 & 0.23 & 2.95 & 2.79 & 3.12 \\
\hline \multirow[t]{2}{*}{ Tpy } & & Dry & 1 & 6.00 & - & - & - & - \\
\hline & Tpbt3 & Dry & 1 & 6.36 & - & - & - & - \\
\hline \multirow[t]{2}{*}{ Tpp } & & - & - & - & - & - & - & - \\
\hline & Tpbt2 & Dry. & 1 & 3.69 & - & - & - & - \\
\hline \multirow[t]{11}{*}{ Tpt } & & - & - & - & - & - & - & - \\
\hline & Tptrv2 & Dry & 1 & 2.26 & - & - & - & - \\
\hline & Tptrn & Dry & 3 & 23.56 & 1.56 & 24.1 & 21.8 & 24.8 \\
\hline & Tptrl & - & - & - & - & - & - & - \\
\hline & Tptpul & Dry & 6 & 30.03 & 7.20 & 29.45 & 20.8 & 39.7 \\
\hline & Tptpmn & Dry & 9 & 43.36 & 3.11 & 43.2 & 39.0 & 50.2 \\
\hline & & Sat & 36 & 39.94 & 2.16 & 39.4 & 36.2 & 45.3 \\
\hline & Tptpll & Dry & 5 & 33.38 & 2.72 & 34.4 & 28.7 & 35.7 \\
\hline & Tptpln & Dry & 4 & 40.9 & 0.87 & 40.9 & 39.9 & 41.9 \\
\hline & Tptpv3 & Dry & 1 & 53.30 & - & - & - & - \\
\hline & Tptpv1 & Dry & 1 & 18.90 & - & - & - & - \\
\hline \multirow[t]{2}{*}{ Tac } & & Dry & 7 & 14.35 & 2.76 & 14.5 & 11.2 & 19.4 \\
\hline & Tacbt & Dry & 1 & 18.70 & - & - & - & - \\
\hline \multirow[t]{2}{*}{ Tcp } & & Dry & 6 & 17.66 & 11.67 & 13.4 & 7.51 & 37.3 \\
\hline & & Sat & 4 & 23.30 & 13.11 & 22.1 & 9.92 & 39.1 \\
\hline
\end{tabular}

Note: Test conditions were at Room Temperature and Confining Pressure varied from atmospheric to $0.7 \mathrm{MPa}$ 
Table 14. Summary of Dynamic Test Results on Poisson's Ratio Obtained from Downhole Seismic Surveys in the Vicinity of Yucca Mountain

\begin{tabular}{|l|l|l|c|c|c|c|c|c|}
\hline \multicolumn{9}{|c|}{ Poisson's Ratio based on suspension velocity profiles } \\
\hline $\begin{array}{c}\text { Formation } \\
\text { or Group }\end{array}$ & $\begin{array}{c}\text { Litho- } \\
\text { strati- } \\
\text { graphic } \\
\text { Unit }\end{array}$ & $\begin{array}{c}\text { Saturation } \\
\text { Condition }\end{array}$ & $\begin{array}{c}\text { Number of } \\
\text { Tests }\end{array}$ & $\begin{array}{c}\text { Mean } \\
\text { Value } \\
(\mathbf{G P a})\end{array}$ & $\begin{array}{c}\text { Standard } \\
\text { Deviation }\end{array}$ & $\begin{array}{c}\text { Median } \\
\text { Value } \\
(\mathbf{G P a})\end{array}$ & $\begin{array}{c}\text { Minimum } \\
\text { Value } \\
(\mathbf{G P a})\end{array}$ & $\begin{array}{c}\text { Maximum } \\
\text { Value } \\
(\mathbf{G P a})\end{array}$ \\
\hline Tmr & Tmbt1 & Ambient & 443 & 0.31 & 0.056 & 0.31 & 0.10 & 0.43 \\
\hline Tp & Tpki & Ambient & 694 & 0.29 & 0.072 & 0.29 & 0 & 0.46 \\
\hline & Tpbt5 & Ambient & 55 & 0.31 & 0.060 & 0.32 & 0.18 & 0.42 \\
\hline Tpc & Tpcrn & Ambient & 736 & 0.30 & 0.077 & 0.30 & 0 & 0.47 \\
\hline & Tpcpul & Ambient & 778 & 0.28 & 0.092 & 0.30 & 0 & 0.47 \\
\hline & Tpcpmn & Ambient & 234 & 0.26 & 0.095 & 0.28 & 0 & 0.44 \\
\hline & Tpcpll & Ambient & 66 & 0.27 & 0.091 & 0.29 & 0.04 & 0.47 \\
\hline & Tpcpln & Ambient & 194 & 0.23 & 0.083 & 0.25 & 0 & 0.37 \\
\hline
\end{tabular}


Table 15. Available Documentation for Unqualified Sources

\begin{tabular}{|c|c|c|c|}
\hline LABORATORY & DTN & $\begin{array}{l}\text { ACCESSION/ } \\
\text { PACKAGE NUMBER }\end{array}$ & RECORDS CONTENTS \\
\hline \multirow{29}{*}{ SNL } & & NNA.19870406.0063 & Report SAND82-1723 \\
\hline & SN0108SD821723.001 & MOY-961126-38-03 & $\begin{array}{l}\text { Records package with supporting records } \\
\text { (some completed after testing) }\end{array}$ \\
\hline & \multirow{3}{*}{ SNSAND83164600.000 } & NNA.19870406.0252 & Report SAND83-1646 \\
\hline & & MOL.19990129.0222 & Method description and list of sample IDs \\
\hline & & MOY-921118-06-07 & $\begin{array}{l}\text { Records package with supporting records } \\
\text { (some completed after testing) }\end{array}$ \\
\hline & \multirow[b]{2}{*}{ SNSAND80145300.000 } & HQS.19880517.1690 & Report SAND80-1453 \\
\hline & & MOY-961213-02-01 & $\begin{array}{l}\text { Records package with supporting records } \\
\text { (some completed after testing) }\end{array}$ \\
\hline & \multirow{3}{*}{ SNL02030180001.001 } & HQS.19880517.1690 & Report SAND80-1453 \\
\hline & & MOY-930316-03-01 & Compressive Test Data and Summaries \\
\hline & & NNA.19930316.0044 & Method description and list of sample IDs \\
\hline & \multirow[b]{2}{*}{ SNSAND81166400.000 } & NNA.19870406.0498 & Report SAND81-1664 \\
\hline & & MOY-960809-05-03 & $\begin{array}{l}\text { Records package with supporting records } \\
\text { (some completed after testing) }\end{array}$ \\
\hline & \multirow[b]{2}{*}{ SNSAND82048100.000 } & NNA.19870406.0036 & Report SAND82-0481 \\
\hline & & MOY-960809-02-01 & $\begin{array}{l}\text { Records package with supporting records } \\
\text { (some completed after testing) }\end{array}$ \\
\hline & \multirow{3}{*}{ SNSAND82131400.000 } & NNA.19900810.0480 & Report SAND82-1314 \\
\hline & & MOY-930304-05-01 & Raw data files and plots \\
\hline & & MOY-961126-38-01 & $\begin{array}{l}\text { Records package with supporting records } \\
\text { (some completed after testing) }\end{array}$ \\
\hline & \multirow{4}{*}{ SNSAND84086000.000 } & NNA.19870406.0156 & Report SAND84-860 \\
\hline & & MOY-921116-11-03 & Laboratory data sheets \\
\hline & & MOY-921116-11-05 & Raw data files and plots \\
\hline & & MOY-970402-03-01 & Sample prep., calibrations \\
\hline & \multirow{3}{*}{ SNSAND85070900.000 } & MOY-970310-02-05 & Raw data, data plots, calibrations \\
\hline & & MOY-970310-02-09 & Sample prep., calibrations \\
\hline & & MOY-930304-06-01 & Raw data, data plots \\
\hline & \multirow{5}{*}{ SNSAND86113100.000 } & NNA.19870601.0013 & Report SAND86-1131 \\
\hline & & MOY-930304-04-01 & Raw data, data plots \\
\hline & & MOY-930304-04-02 & Raw data, data plots \\
\hline & & MOY-961126-35-07 & Sample descriptions \\
\hline & & MOY-970310-02-07 & Sample prep., calibrations \\
\hline
\end{tabular}


Table 15. Available Documentation for Unqualified Sources (Continued)

\begin{tabular}{|c|c|c|c|}
\hline LABORATORY & DTN & $\begin{array}{c}\text { ACCESSION/ } \\
\text { PACKAGE NUMBER }\end{array}$ & RECORDS CONTENTS \\
\hline \multirow{6}{*}{ RE/SPEC } & \multirow{4}{*}{ SNL02033084002.001 } & NNA.19930304.0146 & $\begin{array}{l}\text { Test system description, test results, and } \\
\text { data plots. }\end{array}$ \\
\hline & & NNA.19930304.0147 & Raw data files \\
\hline & & NNA.19890825.0178 & Contractor report and test results. \\
\hline & & MOY-930922-08-01 & Procedures for testing \\
\hline & \multirow[t]{2}{*}{ SNL02072983003.001 } & NNA.19930304.0074 & Contractor report and test results. \\
\hline & & MOY-930922-08-01 & Procedures for testing \\
\hline \multirow{4}{*}{ NER } & \multirow{4}{*}{ SNL02040687003.001 } & NNA.19930728.0088 & Report SAND-92-1810 \\
\hline & & MOY-931208-02-01 & Review package for report \\
\hline & & NNA.19900410.0127 & Procedure \\
\hline & & MOL.19980209.0968 & Raw data files \\
\hline \multirow{15}{*}{ Terra Tek } & \multirow{6}{*}{ SNL02072983001.001 } & NNA.19930304.0078 & Test results and data plots. \\
\hline & & MOL.19990111.0107 & Sample collection. \\
\hline & & MOY-981215-16-04 & Sample collection information. \\
\hline & & MOL.19970428.0083 & $\begin{array}{l}\text { Contractor's final report, test results, test } \\
\text { criteria }\end{array}$ \\
\hline & & MOL.19961002.0162 & Procedure \\
\hline & & MOL.19961002.0163 & Procedure \\
\hline & \multirow{3}{*}{ SNSAND82105500.000 } & NNA.19870406.0062 & Report SAND82-1055 \\
\hline & & MOY-960809-03-03 & Procedures, raw data, data plots. \\
\hline & & MOY-931112-03-02 & QA Manual \\
\hline & \multirow{3}{*}{ SNSAND84110100.000 } & HQS.19880517.1686 & Report SAND84-1101 \\
\hline & & MOY-930330-07-03 & Raw data, data plots \\
\hline & & MOY-960724-05-01 & Sample preparation \\
\hline & \multirow{3}{*}{ SNSAND85070300.000 } & NNA.19891019.0289 & Report SAND85-0703 \\
\hline & & MOY-970402-02-03 & $\begin{array}{l}\text { Sample prep., data plots, calibration, } \\
\text { contractor report }\end{array}$ \\
\hline & & NNA.19900813.0521 & Test requirements \\
\hline \multirow{3}{*}{ USGS/USBR } & \multirow{3}{*}{ GS921283114220.009 } & NNA.19930614.0026 & Raw data, data plots, results \\
\hline & & NNA19930614.0024 & Raw data, data plots, results \\
\hline & & NNA.19930607.0020 & Report \\
\hline
\end{tabular}


Table 16. Summary of Static Poisson's Ratio Results from Saturated Tptpmn Samples by Laboratory

\begin{tabular}{|l|c|c|c|c|c|c|}
\hline & $\begin{array}{c}\text { Terra Tek } \\
\text { Boreholes } \\
\text { Unqualified }\end{array}$ & $\begin{array}{c}\text { Terra Tek } \\
\text { Busted Butte } \\
\text { Unqualified }\end{array}$ & $\begin{array}{c}\text { RE/SPEC } \\
\text { Busted Butte } \\
\text { Unqualified }\end{array}$ & $\begin{array}{c}\text { SNL } \\
\text { Boreholes } \\
\text { Qualified }\end{array}$ & $\begin{array}{c}\text { SNL } \\
\text { Boreholes } \\
\text { Unqualified }\end{array}$ & $\begin{array}{c}\text { SNL } \\
\text { Busted Butte } \\
\text { Unqualified }\end{array}$ \\
\hline Mean & 0.22 & 0.18 & 0.13 & 0.20 & 0.21 & 0.20 \\
\hline Median & 0.21 & 0.18 & 0.14 & 0.20 & 0.21 & 0.21 \\
\hline $\begin{array}{l}\text { Standard } \\
\text { Deviation }\end{array}$ & 0.051 & 0.027 & 0.038 & 0.035 & 0.033 & 0.023 \\
\hline Range & 0.19 & 0.08 & 0.13 & 0.23 & 0.13 & 0.13 \\
\hline Minimum & 0.11 & 0.12 & 0.07 & 0.10 & 0.16 & 0.14 \\
\hline Maximum & 0.30 & 0.21 & 0.20 & 0.33 & 0.29 & 0.27 \\
\hline Count & 19 & 9 & 8 & 46 & 10 & 47 \\
\hline
\end{tabular}

Table 17. Summary of Static Poisson's Ratio Results from Unsaturated Tptpmn Samples by Laboratory

\begin{tabular}{|l|c|c|c|c|}
\hline & $\begin{array}{c}\text { NER } \\
\text { Busted Butte } \\
\text { Unqualified }\end{array}$ & $\begin{array}{c}\text { Re/SPEC } \\
\text { Busted Butte } \\
\text { Unqualified }\end{array}$ & $\begin{array}{c}\text { SNL } \\
\text { ESF } \\
\text { Qualified }\end{array}$ & $\begin{array}{c}\text { SNL } \\
\text { Busted Butte } \\
\text { Unqualified }\end{array}$ \\
\hline Mean & 0.21 & 0.10 & 0.18 & 0.19 \\
\hline Median & 0.23 & 0.12 & 0.17 & 0.18 \\
\hline Standard Deviation & 0.039 & 0.041 & 0.044 & 0.046 \\
\hline Range & 0.07 & 0.11 & 0.27 & 0.20 \\
\hline Minimum & 0.16 & 0.04 & 0.12 & 0.12 \\
\hline Maximum & 0.23 & 0.15 & 0.39 & 0.32 \\
\hline Count & 3 & 7 & 52 & 14 \\
\hline
\end{tabular}

Table 18. Summary of Static Young's Modulus Results (GPa) for Saturated Tptpmn Samples by Laboratory

\begin{tabular}{|l|c|c|c|c|c|c|}
\hline & $\begin{array}{c}\text { NER } \\
\text { Boreholes } \\
\text { Qualified }\end{array}$ & $\begin{array}{c}\text { Terra Tek } \\
\text { Boreholes } \\
\text { Unqualified }\end{array}$ & $\begin{array}{c}\text { Terra Tek } \\
\text { Busted Butte } \\
\text { Unqualified }\end{array}$ & $\begin{array}{c}\text { RE/SPEC } \\
\text { Busted Butte } \\
\text { Unqualified }\end{array}$ & $\begin{array}{c}\text { SNL } \\
\text { Boreholes } \\
\text { Qualified }\end{array}$ & $\begin{array}{c}\text { SNL } \\
\text { Busted Butte } \\
\text { Unqualified }\end{array}$ \\
\hline Mean & 32.30 & 36.18 & 30.56 & 25.57 & 33.18 & 37.89 \\
\hline Median & 33.80 & 35.90 & 30.75 & 25.15 & 34.05 & 37.10 \\
\hline $\begin{array}{l}\text { Standard } \\
\text { Deviation }\end{array}$ & 7.66 & 3.09 & 2.07 & 5.71 & 4.34 & 5.48 \\
\hline Range & 27.1 & 11.4 & 6.1 & 14.4 & 23.1 & 22.0 \\
\hline Minimum & 13.4 & 32.2 & 28.0 & 18.6 & 16.8 & 25.3 \\
\hline Maximum & 40.5 & 43.6 & 34.1 & 33.0 & 39.9 & 47.3 \\
\hline Count & 16 & 16 & 9 & 8 & 38 & 49 \\
\hline
\end{tabular}


Table 19. Summary of Static Young's Modulus Results (GPa) for Unsaturated Tptpmn Samples by Laboratory

\begin{tabular}{|l|c|c|c|c|c|}
\hline & $\begin{array}{c}\text { NER } \\
\text { ESF } \\
\text { Qualified }\end{array}$ & $\begin{array}{c}\text { NER } \\
\text { Busted Butte } \\
\text { Unqualified }\end{array}$ & $\begin{array}{c}\text { RE/SPEC } \\
\text { Busted Butte } \\
\text { Unqualified }\end{array}$ & $\begin{array}{c}\text { SNL } \\
\text { ESF } \\
\text { Qualified }\end{array}$ & $\begin{array}{c}\text { SNL Busted } \\
\text { Butte } \\
\text { Unqualified }\end{array}$ \\
\hline Mean & 32.40 & 47.27 & 37.84 & 34.34 & 38.07 \\
\hline Median & 32.65 & 47.27 & 37.50 & 34.50 & 39.25 \\
\hline $\begin{array}{l}\text { Standard } \\
\text { Deviation }\end{array}$ & 2.93 & 1.18 & 1.82 & 4.86 & 4.35 \\
\hline Range & 11.0 & 1.7 & 5.5 & 23.0 & 13.6 \\
\hline Minimum & 25.7 & 46.4 & 36.3 & 20.1 & 32.1 \\
\hline Maximum & 36.7 & 48.1 & 41.8 & 43.1 & 45.7 \\
\hline Count & 22 & 2 & 7 & 30 & 14 \\
\hline
\end{tabular}

Table 20. Summary of Static Poisson's Ratio Results for Saturated Tptpmn Samples by Location

\begin{tabular}{|l|c|c|c|}
\hline & Qualified Boreholes & Unqualified Boreholes & Unqualified Busted Butte \\
\hline Mean & 0.20 & 0.21 & 0.18 \\
\hline Median & 0.20 & 0.21 & 0.20 \\
\hline Standard Deviation & 0.033 & 0.045 & 0.048 \\
\hline Range & 0.23 & 0.19 & 0.28 \\
\hline Minimum & 0.10 & 0.11 & -0.01 \\
\hline Maximum & 0.33 & 0.30 & 0.27 \\
\hline Count & 70 & 29 & 70 \\
\hline
\end{tabular}

Table 21. Summary of Static Poisson's Ratio Results for Unsaturated Tptpmn Samples by Location

\begin{tabular}{|l|c|c|c|}
\hline & Qualified, ESF & Unqualified, Borehole & Unqualified, Busted Butte \\
\hline Mean & 0.18 & 0.19 & 0.17 \\
\hline Median & 0.17 & 0.19 & 0.18 \\
\hline Standard Deviation & 0.044 & 0.049 & 0.061 \\
\hline Range & 0.27 & 0.07 & 0.28 \\
\hline Minimum & 0.12 & 0.15 & 0.04 \\
\hline Maximum & 0.39 & 0.22 & 0.32 \\
\hline Count & 52 & 2 & 24 \\
\hline
\end{tabular}


Table 22. Summary of Static Young's Modulus Values (GPa) from Saturated Tptpmn Samples by Location

\begin{tabular}{|l|c|c|c|c|}
\hline & $\begin{array}{c}\text { Qualified } \\
\text { Boreholes }\end{array}$ & $\begin{array}{c}\text { Unqualified } \\
\text { Boreholes }\end{array}$ & $\begin{array}{c}\text { Qualified Busted } \\
\text { Butte }\end{array}$ & $\begin{array}{c}\text { Unqualified Busted } \\
\text { Butte }\end{array}$ \\
\hline Mean & 32.92 & 33.71 & 38.2 & 35.40 \\
\hline Median & 34.05 & 33.55 & 36.9 & 35.05 \\
\hline Standard Deviation & 5.47 & 3.88 & 3.71 & 6.78 \\
\hline Range & 27.1 & 15.5 & 9.3 & 28.7 \\
\hline Minimum & 13.4 & 28.1 & 34.7 & 18.6 \\
\hline Maximum & 40.5 & 43.6 & 44.0 & 47.3 \\
\hline Count & 54 & 28 & 5 & 66 \\
\hline
\end{tabular}

Table 23. Summary of Static Young's Modulus Values (GPa) from Unsaturated Tptpmn Samples by Location

\begin{tabular}{|l|c|c|}
\hline & Qualified, ESF & Unqualified Busted Butte \\
\hline Mean & 33.52 & 38.80 \\
\hline Median & 34.10 & 37.70 \\
\hline Standard Deviation & 4.23 & 4.39 \\
\hline Range & 23.0 & 16.0 \\
\hline Minimum & 20.1 & 32.1 \\
\hline Maximum & 43.1 & 48.1 \\
\hline Count & 52 & 23 \\
\hline
\end{tabular}

Table 24. Summary of Static Young's Modulus Values (GPa) for Saturated Tptpll Samples by Laboratory

\begin{tabular}{|l|c|c|c|}
\hline & Qualified, NER & Unqualified, SNL & Unqualified, Terra Tek \\
\hline Mean & 26.77 & 27.59 & 27.50 \\
\hline Median & 27.40 & 25.55 & 30.60 \\
\hline Standard Deviation & 7.81 & 5.90 & 7.93 \\
\hline Range & 20.7 & 18.9 & 35.5 \\
\hline Minimum & 16.9 & 19.2 & 2.4 \\
\hline Maximum & 37.6 & 38.1 & 38.0 \\
\hline Count & 7 & 10 & 28 \\
\hline
\end{tabular}


Table 25. Summary of Dynamic Poisson's Ratio Results for Tptpmn Samples by Saturation and Location

\begin{tabular}{|l|c|c|c|c|}
\hline & $\begin{array}{c}\text { Qualified, Dry, } \\
\text { Borehole, from } \\
\text { USBR }\end{array}$ & $\begin{array}{c}\text { Unqualified, Dry, } \\
\text { Busted Butte, } \\
\text { from NER }\end{array}$ & $\begin{array}{c}\text { Unqualified, } \\
\text { Saturated, } \\
\text { Busted Butte, } \\
\text { from NER }\end{array}$ & $\begin{array}{c}\text { Unqualified, } \\
\text { Saturated, } \\
\text { Borehole, from } \\
\text { SNL }\end{array}$ \\
\hline Mean & 0.126 & 0.212 & 0.240 & 0.218 \\
\hline Median & 0.126 & 0.210 & 0.230 & 0.220 \\
\hline Standard Deviation & 0.003 & 0.012 & 0.020 & 0.018 \\
\hline Range & 0.005 & 0.03 & 0.05 & 0.07 \\
\hline Minimum & 0.124 & 0.20 & 0.23 & 0.18 \\
\hline Maximum & 0.129 & 0.23 & 0.28 & 0.25 \\
\hline Count & 2 & 8 & 6 & 30 \\
\hline
\end{tabular}

Table 26. Summary of Dynamic Young's Modulus Results (GPa) for Tptpmn Samples by Saturation and Location

\begin{tabular}{|l|c|c|c|c|}
\hline & $\begin{array}{c}\text { Qualified, Dry, } \\
\text { Borehole, from } \\
\text { USBR }\end{array}$ & $\begin{array}{c}\text { Unqualified, Dry, } \\
\text { Busted Butte, } \\
\text { from NER }\end{array}$ & $\begin{array}{c}\text { Unqualified, } \\
\text { Saturated, } \\
\text { Busted Butte, } \\
\text { from NER }\end{array}$ & $\begin{array}{c}\text { Unqualified, } \\
\text { Saturated, } \\
\text { Borehole, from } \\
\text { SNL }\end{array}$ \\
\hline Mean & 40.70 & 44.12 & 42.89 & 39.35 \\
\hline Median & 40.70 & 44.10 & 43.61 & 39.15 \\
\hline Standard Deviation & 2.40 & 2.99 & 2.54 & 1.54 \\
\hline Range & 3.4 & 9.4 & 6.8 & 6.4 \\
\hline Minimum & 39.0 & 40.8 & 38.5 & 36.2 \\
\hline Maximum & 42.4 & 50.2 & 45.3 & 42.6 \\
\hline Count & 2 & 7 & 6 & 30 \\
\hline
\end{tabular}


APPENDIX A

STRATIGRAPHIC COLUMN OF THE YUCCA MOUNTAIN VICINITY 
Table A-1. Stratigraphic Column of the Yucca Mountain Vicinity

\begin{tabular}{|c|c|c|c|c|}
\hline Definition/Name & Group & Formation & Member & Zone \\
\hline Timber Mountain Group & $\mathrm{Tm}$ & & & \\
\hline Rainier Mesa Tuff & & Tmr & & \\
\hline Paintbrush Group & $\mathrm{Tp}$ & & & \\
\hline Post tuff unit "x" bedded tuff & & & Tpbt6 & \\
\hline Tuff unit "x" & & & Tpki & \\
\hline Pre-tuff unit "x" bedded tuff & & & Tpbt5 & \\
\hline Tiva Canyon Tuff & & $\mathrm{Tpc}$ & & \\
\hline Crystal-Rich Member & & & Tpcr & \\
\hline Vitric zone & & & & Tpcrv \\
\hline Nonlithophysal zone & & & & Tpcrn \\
\hline Lithophysal zone & & & & Tpcrl \\
\hline Crystal-Poor Member & & & Tpcp & \\
\hline Upper lithophysal zone & & & & Tpcpul \\
\hline Middle nonlithophysal zone & & & & Tpcpmn \\
\hline Lower lithophysal zone & & & & Tpcpll \\
\hline Lower nonlithophysal zone & & & & Tpcpln \\
\hline Vitric zone & & & & Tpcpv \\
\hline Pre-Tiva Canyon bedded tuff & & & Tpbt4 & \\
\hline Yucca Mountain Tuff & & Tpy & & \\
\hline Pre-Yucca Mountain bedded tuff & & & Tpbt3 & \\
\hline Pah Canyon Tuff & & Tpp & & \\
\hline Pre-Pah Canyon bedded tuff & & & Tpbt2 & \\
\hline Topopah Spring Tuff & & Tpt & & \\
\hline Crystal-Rich Member & & & Tptr & \\
\hline Vitric zone & & & & Tptrv \\
\hline Nonlithophysal zone & & & & Tptrn \\
\hline Lithophysal zone & & & & Tptrl \\
\hline
\end{tabular}


Table A-1. Stratigraphic Column of the Yucca Mountain Vicinity (Continued)

\begin{tabular}{|c|c|c|c|c|c|}
\hline \multicolumn{2}{|c|}{ Definition/Name } & \multirow[t]{2}{*}{ Group } & \multirow[t]{2}{*}{ Formation } & \multirow{2}{*}{$\begin{array}{l}\text { Member } \\
\text { Tptp }\end{array}$} & \multirow[t]{2}{*}{ Zone } \\
\hline & Crystal-Poor Member & & & & \\
\hline & Lithic-rich zone & & & & $\begin{array}{l}\text { Tptpf or } \\
\text { Tptrf }\end{array}$ \\
\hline & Upper lithophysal zone & & & & Tptpul \\
\hline & Middle nonlithophysal zone & & & & Tptpmn \\
\hline & Lower lithophysal zone & & & & Tptpll \\
\hline & Lower nonlithophysal zone & & & & Tptpln \\
\hline & Vitric zone & & & & Tptpv \\
\hline & Pre-Topopah Spring bedded tuff & & & Tpbt1 & \\
\hline \multicolumn{2}{|r|}{ Calico Hills Formation } & & Tac & & \\
\hline & Bedded tuff & & & Tacbt & \\
\hline \multicolumn{2}{|c|}{ Crater Flat Group } & Tc & & & \\
\hline \multicolumn{2}{|r|}{ Prow Pass } & & Tcp & & \\
\hline & Upper vitric nonwelded to partially welded zone & & & Tcpuv & \\
\hline & $\begin{array}{l}\text { Upper crystallized nonwelded to partially welded } \\
\text { zone }\end{array}$ & & & Tcpuc & \\
\hline & Crystallized moderately to densely welded zone & & & Tcpm & \\
\hline & $\begin{array}{l}\text { Lower crystallized nonwelded to partially welded } \\
\text { zone }\end{array}$ & & & Tcplc & \\
\hline & Lower vitric nonwelded to partially welded zone & & & Tcplv & \\
\hline & Bedded tuff & & & Tcpbt & \\
\hline \multicolumn{2}{|r|}{ Bullfrog Tuff } & & $\mathrm{Tcb}$ & & \\
\hline & Upper vitric nonwelded to partially welded zone & & Tcbuv & & \\
\hline & $\begin{array}{l}\text { Upper crystallized nonwelded to partially welded } \\
\text { zone }\end{array}$ & & Tcbuc & & \\
\hline & Crystallized moderately to densely welded zone & & Tcbm & & \\
\hline & $\begin{array}{l}\text { Lower crystallized nonwelded to partially welded } \\
\text { zone }\end{array}$ & & Tcblc & & \\
\hline & Lower vitric nonwelded to partially welded zone & & Tcblv & & \\
\hline & Bedded tuff & & & Tcbbt & \\
\hline \multicolumn{2}{|r|}{ Tram Tuff } & & Tct & & \\
\hline & Bedded tuff & & & Tctbt & \\
\hline & Lava and flow breccia (informal) & & & TII & \\
\hline & Bedded tuff & & & Tllbt & \\
\hline
\end{tabular}


Table A-1. Stratigraphic Column of the Yucca Mountain Vicinity (Continued)

\begin{tabular}{|c|c|c|}
\hline Lithic Ridge Tuff & $\operatorname{Tr}$ & \\
\hline Bedded tuff & & Tlrbt \\
\hline Lava and flow breccia (informal) & & TII2 \\
\hline Bedded tuff & & TIllabt \\
\hline Lava and flow breccia (informal) & & TII3 \\
\hline Bedded tuff & & TIllbt \\
\hline Older tuffs (informal) & & $\mathrm{Tt}$ \\
\hline Unit a (informal) & & Tta \\
\hline Unit b (informal) & & Ttb \\
\hline Unit c (informal) & & Ttc \\
\hline Sedimentary rocks and calcified tuff (informal) & & Tca \\
\hline Tuff of Yucca Flat (informal) & & Tyf \\
\hline Lone Mountain Dolomite & SIm & \\
\hline Roberts Mountain Formation & Srm & \\
\hline
\end{tabular}

Modified from DTN MO0004QGFMPICK.000 and GS931208314211.049 